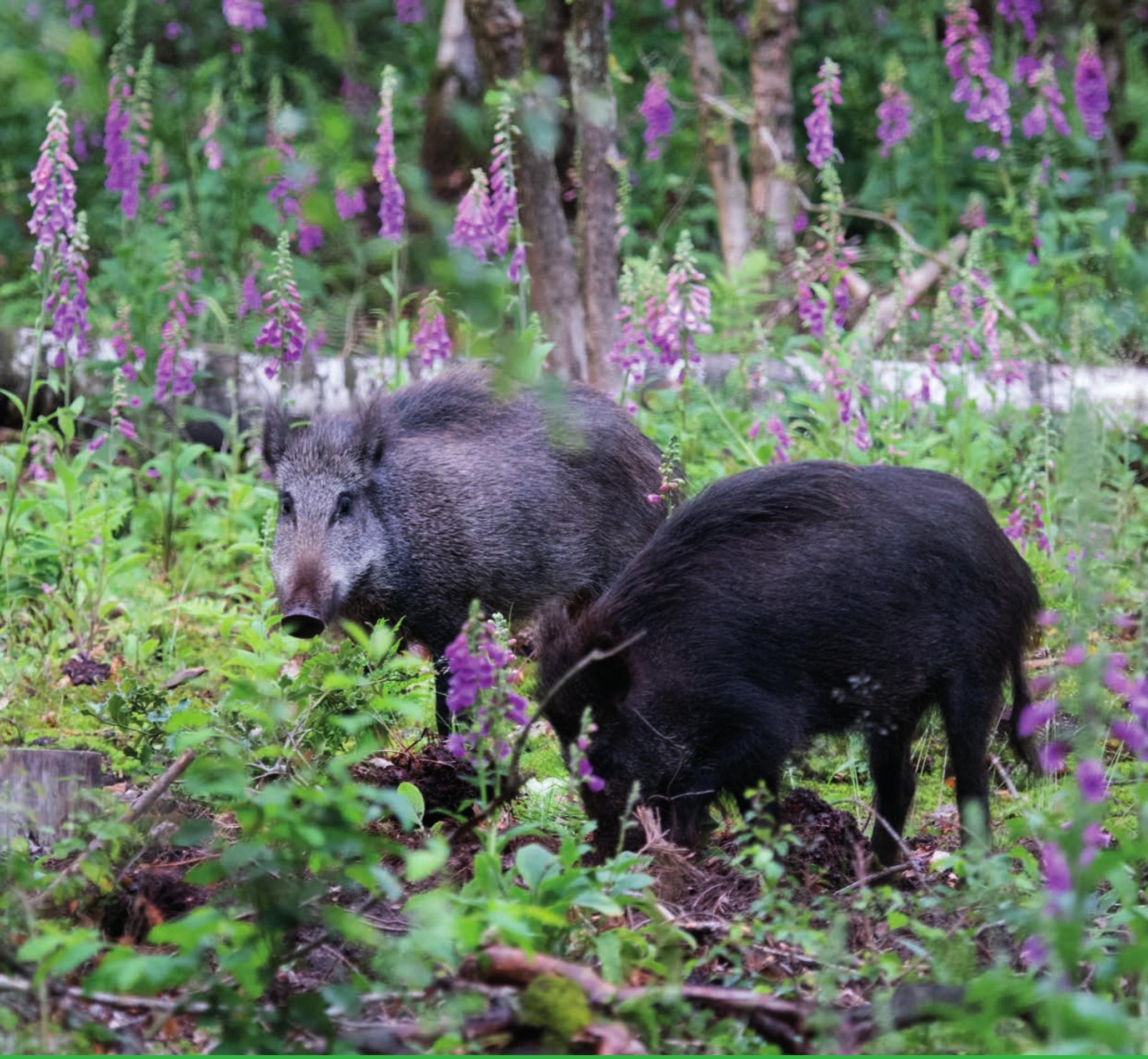

\title{
Effecten van hoefdieren op Natura 2000-boshabitattypen op de Veluwe
}





\section{Effecten van hoefdieren op Natura 2000- boshabitattypen op de Veluwe}

Jan den Ouden ${ }^{1}$, Dennis Lammertsma² \& Hugh Jansman²

1 Leerstoelgroep Bosecologie en bosbeheer, Wageningen University

2 Team Dierecologie, Wageningen Environmental Research

Dit onderzoek is uitgevoerd door Wageningen University en Wageningen Environmental Research in opdracht van, en gefinancierd door, de Provincie Gelderland.

Wageningen University \& Research

Wageningen, juni 2020

Rapport Wageningen University /

WENR-rapport 3013

ISSN 1566-7197 
den Ouden, J., D.R. Lammertsma \& H.A.H Jansman, 2020. Effecten van hoefdieren op Natura 2000boshabitattypen op de Veluwe. Wageningen, Rapport Wageningen University / Wageningen Environmental Research, Rapport 3013. 90 blz.; 24 fig.; 3 tab.; 220 ref.

De provincie Gelderland heeft gevraagd om nader inzicht te krijgen in de relatie tussen de populatiegroottes van hoefdieren en de kwaliteit van de belangrijkste Natura 2000-boshabitattypen op de Veluwe: de Beuken-eikenbossen met hulst (H9120) en de Oude eikenbossen (H9190). Kernvragen richtten zich op de maximale aantallen van verschillende hoefdiersoorten waarbij bosverjonging mogelijk blijft en welk wildbeheer gewenst is om Natura 2000-doelen in stand te houden. Het rapport bespreekt, op basis van een literatuurstudie, de invloed van hoefdieren op bosverjonging en het voorkomen van populaties (bijzondere) kwaliteitssoorten in de habitats. De nadruk ligt hierbij vooral op het edelhert, ree en wild zwijn. Het wildbeheer wordt uitgewerkt aan de hand van een aantal scenario's, waarna aanbevelingen worden gedaan om de heersende wilddruk op de boshabitats te verlagen. Een belangrijke aanbeveling daarbij is om bij het vaststellen van de benodigde mate van ingrijpen in de populatiegroottes van hoefdieren, en bij het beoordelen van de effectiviteit van uitgevoerde maatregelen, zich niet alleen te baseren op aantalsschattingen, maar vooral te evalueren op basis van monitoring van ecologische effecten.

Trefwoorden: bosverjonging, wilddruk, hoefdieren, wildbeheer, Natura 2000, habitattypen, Oude eikenbossen, Beuken-Eikenbossen met hulst, kwaliteitssoorten

Dit rapport is gratis te downloaden van https://doi.org/10.18174/525450 of op www.wur.nl/environmental-research (ga naar 'Wageningen Environmental Research' in de grijze balk onderaan). Van dit rapport zijn geen gedrukte exemplaren beschikbaar.

2020 Wageningen University / Wageningen Environmental Research (instituut binnen de rechtspersoon Stichting Wageningen Research), Postbus 47, 6700 AA Wageningen, T 0317480700 , www.wur.nl/environmental-research. Wageningen University en Wageningen Environmental Research zijn onderdeel van Wageningen University \& Research.

- Overname, verveelvoudiging of openbaarmaking van deze uitgave is toegestaan mits met duidelijke bronvermelding.

- Overname, verveelvoudiging of openbaarmaking is niet toegestaan voor commerciële doeleinden en/of geldelijk gewin.

- Overname, verveelvoudiging of openbaarmaking is niet toegestaan voor die gedeelten van deze uitgave waarvan duidelijk is dat de auteursrechten liggen bij derden en/of zijn voorbehouden.

Wageningen University en Wageningen Environmental Research aanvaarden geen aansprakelijkheid voor eventuele schade voortvloeiend uit het gebruik van de resultaten van dit onderzoek of de toepassing van de adviezen.

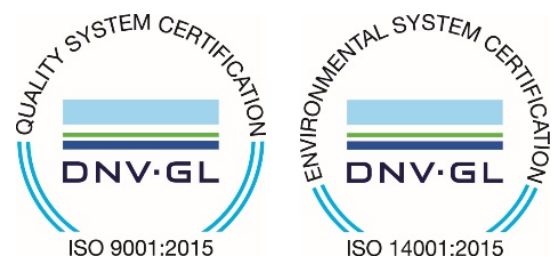

Wageningen Environmental Research werkt sinds 2003 met een ISO 9001 gecertificeerd kwaliteitsmanagementsysteem. In 2006 heeft Wageningen Environmental Research een milieuzorgsysteem geïmplementeerd, gecertificeerd volgens de norm ISO 14001.

Wageningen Environmental Research geeft via ISO 26000 invulling aan haar maatschappelijke verantwoordelijkheid.

Rapport Wageningen University / Wageningen Environmental Research Rapport 3013 | ISSN 1566-7197

Foto omslag: Hugh Jansman 


\section{Inhoud}

$\begin{array}{ll}\text { Verantwoording } & 5\end{array}$

$\begin{array}{ll}\text { Samenvatting } & 7\end{array}$

1

Inleiding

$\begin{array}{ll}\text { De Veluwe en Natura 2000-habitats } & 10\end{array}$

2.1 De Veluwe, een beknopte biografie $\quad 10$

2.1.1 Bodemsubstraat en water 10

2.1.2 Vegetatie 10

2.1.3 Grote herbivoren 11

2.1.4 Ontginning en huidige landschappelijke context $\quad 11$

2.2 H9120: Beuken-eikenbossen met hulst 13

2.2.1 Algemene karakterisering 13

2.2.2 Dynamiek 14

2.2.3 Kwaliteitskenmerken $\quad 15$

$\begin{array}{ll}2.3 \text { H9190: Oude eikenbossen } & 18\end{array}$

2.3.1 Algemene karakterisering 18

2.3.2 Dynamiek 19

$\begin{array}{ll}2.3 .3 \text { Kwaliteitskenmerken } & 20\end{array}$

2.4 Interacties tussen grote herbivoren en boshabitats $\quad 22$

$\begin{array}{llr}3 & \text { Effecten van hoefdieren op vegetatie } & 26\end{array}$

$3.1 \quad$ Voedselkeuze en terreingebruik $\quad 26$

$\begin{array}{ll}3.1 .1 \text { Edelhert } & 27\end{array}$

3.1 .2 Wild zwijn 28

$\begin{array}{ll}3.1 .3 \text { Ree } & 29\end{array}$

$\begin{array}{ll}3.1 .4 & \text { Damhert } \\ 3.1 .5 & 29\end{array}$

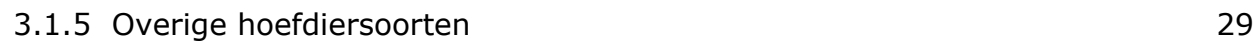

3.1.6 Effecten op basis van dieetkeus en terreingebruik 30

$\begin{array}{lll}3.2 & \text { Preferentie } & 31\end{array}$

3.2.1 Vraat aan bomen en struiken $\quad 31$

3.2.2 Vraat aan overige vegetatie $\quad 34$

$\begin{array}{lll}3.3 & \text { Verstoring in vegetatie en bodem } & 35\end{array}$

3.3.1 Vraat aan knoppen en bladeren $\quad 35$

3.3.2 Bastvraat $\quad 36$

3.3.3 Bodemwoeling en compactie $\quad 37$

$\begin{array}{lll}3.4 & \text { Gevolgen voor overleving en groei } & 38\end{array}$

$\begin{array}{lll}3.5 & \text { Dosis-effectrelaties } & 40\end{array}$

4 Dynamiek en draagkracht hoefdieren

4.1 Populatiedynamiek $\quad 42$

4.1.1 Reproductie, groei en sterfte $\quad 42$

4.1.2 Immigratie en emigratie $\quad 44$

4.1.3 Levensvatbare populaties en genetische variatie $\quad 44$

$\begin{array}{lll}4.2 & \text { Draagkracht } & 46\end{array}$

$\begin{array}{lll}4.3 & \text { Vaststellen van aantallen } & 47\end{array}$

$\begin{array}{ll}4.3 .1 & \text { Zichtwaarnemingen }\end{array}$

$\begin{array}{ll}\text { 4.3.2 Cameravallen } & 48\end{array}$

$\begin{array}{ll}4.3 .3 \text { Keuteltellingen } & 48\end{array}$ 
5.1 Vegetatiestructuur

5.2 Vraatpercentages

51

5.3 Aanwezigheid soorten

5.4 Vraatgrens

54

5.5 Struikvorm

54

5.6 Bodemverstoring

6.1 Autonome ontwikkeling van populaties (niet ingrijpen) 57

6.2 Autonome ontwikkeling onder invloed van natuurlijke predatie 58

$\begin{array}{ll}6.2 .1 \text { Wolf } & 58\end{array}$

6.2.2 Lynx 60

6.2.3 Effecten van wolf op hoefdieren $\quad 60$

$\begin{array}{lll}6.3 & \text { Huidig beheer } & 62\end{array}$

6.4 Generieke verlaging van de wildstand 65

6.5 Gedifferentieerde bejaging en beheer op maat 65

$\begin{array}{lll}6.6 & \text { Afleiden en afweren } & 67\end{array}$

$\begin{array}{lll}6.7 & \text { Uitrasteren } & 69\end{array}$

$\begin{array}{lll}7 & \text { Consequenties voor beheer } & \mathbf{7 0}\end{array}$

$\begin{array}{lll}7.1 & \text { Uitgangspunten } & 70\end{array}$

$\begin{array}{lll}7.2 & \text { Wildstanden en effecten op boshabitats } & 72\end{array}$

$\begin{array}{lll}7.3 & \text { Monitoring van hoefdieren en hun effecten } & 72\end{array}$

$\begin{array}{lll}7.4 & \text { Reguleren van wilddruk } & 73\end{array}$

$\begin{array}{lll}7.5 & \text { Organisatie en draagvlak } & 74\end{array}$ 


\section{Verantwoording}

Dit rapport is geschreven in opdracht van de provincie Gelderland, op basis van een bureaustudie. De begeleiding vanuit de Provincie Gelderland werd verzorgd door Adri Kromwijk, Robbert Wolf, Martin Bons en Jaap Ex.

Het rapport is intern gereviewd door dr. A.T. Kuiters van Wageningen Environmental Research.

Rapport: 3013

Projectnummer: 5160958101 


\section{Samenvatting}

De Veluwe is een belangrijk bolwerk voor de Natura 2000-habitattypen Oude eikenbossen (H9190) en Beuken-eikenbossen met hulst (H9120) in Nederland. De huidige staat van instandhouding, voor het gehele Nederlandse areaal, is matig ongunstig voor Beuken-eikenbossen met hulst, en zeer ongunstig voor Oude eikenbossen. De vergroting van de kwaliteit en de omvang van deze habitats zijn een belangrijk doel in het natuurbeleid van de provincie Gelderland.

Het Beheerplan Natura 2000 Veluwe constateert dat de gewenste kwaliteit van de boshabitats negatief wordt beïnvloed door de huidige begrazingsintensiteit door hoefdieren. Dit geldt met name voor de invloed van begrazing op de vestiging en groei van boomsoorten, op de structuur van het bos en op populaties van (bijzondere) kwaliteitssoorten en typische soorten van de habitattypen. Om deze reden is het noodzakelijk om meer inzicht te hebben in de relatie tussen begrazing en de kwaliteit van de genoemde boshabitattypen en op welke wijze hierin kan worden gestuurd. Het doel van deze studie is daarom de beantwoording van twee kernvragen:

1. Wat is de wilddruk waarbij natuurlijke verjonging van bij Natura 2000-boshabitattypen behorende boom- en struiksoorten nog van de grond komt?

2. Welk wildbeheer is gewenst om de Natura 2000-habitattypen in stand te houden?

Uit de literatuur blijkt dat hoefdierpopulaties sterk sturen in de dichtheid en samenstelling van de bosverjonging en ondergroei. Bij toenemende dichtheden wordt een steeds groter deel van de verjonging aangevreten waarbij als eerste de smakelijkste soorten, zoals wilde lijsterbes en vuilboom, worden gepakt, en naarmate de beschikbaarheid van smakelijke soorten afneemt, uiteindelijk ook de minder smakelijke soorten. Een toenemende graasdruk leidt dan tot een afname van de diversiteit aan boom- en struiksoorten, het verdwijnen van de struiklaag en uiteindelijk de dominantie van naaldboomsoorten in de verjonging.

Hoewel voor de beoordeling van de structuur en functie van de Natura 2000-boshabitattypen in het kader van de staat van instandhouding geen expliciete voorwaarden zijn gesteld over verjonging, blijft verjonging van loofbomen op de langere termijn nodig voor het in stand houden van de boshabitats met de daaraan gekoppelde vegetatietypen en soorten. De provincie Gelderland heeft dit dan ook als expliciet doel geformuleerd voor de boshabitattypen op de Veluwe. Voldoende verjonging van bij de groeiplaatsen van de habitattypen behorende boom- en struiksoorten is mogelijk bij populatiedichtheden van naar schatting maximaal 1-1,5 edelherten of 4 reeën en 2-4 wilde zwijnen per 100 ha.

Over de relatie tussen hoefdierdichtheden en (bijzondere) kwaliteitssoorten is nauwelijks informatie beschikbaar. Uit de literatuur komt naar voren dat vooral dalkruid en braam gevoelig zijn voor een hogere graasdruk. Een hoge dichtheid van het wild zwijn leidt tot dermate grote en frequente bodemverstoring dat dit ten koste kan gaan van ter plekke aanwezige plantensoorten, zoals hengel, en bodemmossen en mycorrhizae-vormende paddenstoelen. Feitelijk worden bij intensieve bodemwoeling de meeste aanwezige generatief vermeerderende soorten vernietigd. De hazelworm heeft wellicht te lijden van directe predatie door wild zwijn. Voor de overige soorten is nauwelijks informatie voorhanden of zijn de effecten niet aangetoond of naar verwachting klein. Het is niet mogelijk om voor deze soorten een bovengrens aan te geven in wilddruk om negatieve effecten op populatieniveau te voorkomen. Nader onderzoek hiernaar is zeer gewenst. Wel is duidelijk dat enige wilddruk gunstig is voor de soortdiversiteit. 
In dit rapport zijn diverse scenario's onderzocht voor het beheer van populaties hoefdieren. Wanneer hoefdierpopulaties niet worden beheerd, al dan niet in aanwezigheid van grote predatoren, zullen de dichtheden veel hoger zijn dan nu het geval is, met grote negatieve effecten op de Natura 2000boshabitats. Ook door maatregelen als het afweren en afleiden van hoefdieren kan de wilddruk onvoldoende worden gestuurd om negatieve effecten te voorkomen. Exclosures (rasters) bieden wel een optimale bescherming, maar zijn te selectief in ruimtelijke zin, duur en verkleinen het areaal dat ter beschikking staat aan hoefdieren.

Twee scenario's lijken voor de hand te liggen om ongewenste effecten op de Natura 2000-boshabitats te voorkomen. De eerste is een generieke verlaging van de aantallen hoefdieren op de Veluwe. Hierdoor worden de totale populatiegroottes, met name voor edelhert, echter flink lager dan de aantallen die nodig zijn voor het in stand houden van een minimale levensvatbare populatie op de lange termijn. Op de korte termijn is dit waarschijnlijk geen probleem. Tevens zijn er effecten op de wildzichtbaarheid. Bij dit scenario is flankerend beleid nodig om deze problemen te voorkomen, zoals het faciliteren van immigratie vanuit populaties buiten de Veluwe.

Een tweede mogelijk scenario betreft maatwerk, waarbij wilddichtheden lokaal variëren. Het kwetsbaarste habitattype voor een hoge wilddruk, de Beuken-eikenbossen met hulst, concentreert zich vooral in het deel van de Veluwe boven de A1 en langs de Veluwezoom. Overwogen kan worden om in kleinere eenheden (enkele tientallen $\mathrm{km}^{2}$ ) een generieke verlaging van de wildstand te realiseren. Ook schrikjacht (ook wel ecologische jacht genoemd) kan daarbij een mogelijkheid zijn. Hierbij wordt op nog kleinere schaal gevarieerd in jachtdruk ter vergroting van de verjongingsmogelijkheden. In theorie zou dit lokaal de wilddruk kunnen verminderen, maar in de praktijk is hier nauwelijks nog ervaring mee opgedaan en staan nog veel vragen open.

Naast het verlagen van de wildstand is het aan te bevelen om geen rustgebieden te creëren in kwalificerend boshabitat of in de directe nabijheid daarvan, om te voorkomen dat deze als daginstand gaan fungeren. Sturing van het terreingebruik door een hogere verstoringsdruk door recreatie en jacht in deze boshabitats kan een aanvullend instrument zijn, maar alleen als hierdoor geen negatieve effecten optreden op andere kwaliteitsaspecten van de habitat.

Maatschappelijke verantwoording voor de regulering van de wildstand is essentieel voor het welslagen van benodigd beleid en de daaruit voortvloeiende maatregelen. Wanneer het faunabeheer zich ook op de ecologische effecten richt, zullen de doelstelling en de uitvoering van het faunabeheer zich veel meer moeten baseren op gedetailleerde informatie omtrent het terreingebruik en gedrag van de hoefdieren op de Veluwe en op monitoring van de effecten. Dit vraagt om heldere doelen en keuzes én een professionele uitvoering. Ongeacht het scenario dat wordt gevolgd, blijft het cruciaal om niet zozeer te sturen op aantallen dieren, maar op de effecten die hoefdieren uitoefenen op het ecosysteem. Daartoe zouden een gericht monitoringsnetwerk en een helder afwegingskader kunnen worden ontwikkeld als integraal onderdeel van het wildbeheer. 


\section{$1 \quad$ Inleiding}

De Veluwe is een belangrijk bolwerk voor de Natura 2000-habitattypen Oude eikenbossen (H9190) en Beuken-eikenbossen met hulst (H9120) in Nederland. Vooral voor Oude eikenbossen levert de Veluwe een relatief grote bijdrage in het totaal aanwezige areaal in Nederland (Bijlsma et al., 2008). Beide habitattypen liggen in verschillende kernen verspreid over de Veluwe en leveren een belangrijke bijdrage aan de biodiversiteit van het gebied. De vergroting van de kwaliteit en de omvang van deze habitats zijn dan ook een belangrijk doel in het provinciale natuurbeleid (Provincie Gelderland, 2017).

Voor het gehele Nederlandse areaal aan Beuken-eikenbossen met hulst is de huidige staat van instandhouding matig ongunstig wat betreft oppervlakte, structuur en functie en toekomstperspectief. Voor Oude eikenbossen is de huidige staat van instandhouding voor laatst genoemde aspecten zelfs zeer ongunstig. Alleen qua areaal is de staat van instandhouding als gunstig beoordeeld (Janssen et al., 2020). Beide habitattypen worden bedreigd door verzuring en vermesting als gevolg van een voortdurende overmatige stikstofdepositie. Ook de aanwezigheid of vestiging van exoten of niet bij de habitat behorende soorten vormt een bedreiging. Versnippering is een bedreiging voor de diversiteit, met name voor weinig mobiele soorten zoals oud-bosplanten. Daarnaast kan onzorgvuldig bosbeheer een belemmering vormen voor de ontwikkeling naar rijkere en gestructureerde bossen (European Environmental Agency, 2019).

Naast de hierboven benoemde bedreigingen wordt in het huidige Beheerplan Natura 2000 Veluwe (Provincie Gelderland, 2017) geconstateerd dat beide boshabitattypen gevoelig zijn voor overbegrazing en dat de huidige begrazingsintensiteit de gewenste kwaliteit van de boshabitats negatief kan beïnvloeden. Dit geldt met name voor de invloed van begrazing op de vestiging en groei van boomsoorten, op de structuur van het bos door aantasting van mantel-zoomvegetaties en ook populaties van typische en (bijzondere) kwaliteitssoorten zouden negatief kunnen worden beïnvloed door een hoge wildstand. Om deze reden is het noodzakelijk om meer inzicht te hebben in de impact van begrazing op de genoemde boshabitattypen en op welke wijze hierop kan worden gestuurd (zie onder andere Gedeputeerde Staten Gelderland, 2019).

In dit rapport wordt middels een bureaustudie op hoofdlijnen antwoord gezocht op de onderstaande kernvragen:

1. Wat is de wilddruk waarbij natuurlijke verjonging van bij Natura 2000-boshabitattypen behorende boom- en struiksoorten nog van de grond komt?

2. Welk wildbeheer is gewenst om de Natura 2000-habitattypen in stand te houden?

Allereerst wordt in dit rapport een korte kenschets gegeven van de Veluwe met de twee belangrijke boshabitattypen Beuken-eikenbossen met hulst (H9120) en Oude eikenbossen (H9190), en de globale invloed van hoefdieren en het beheer op deze habitattypen (hoofdstuk 2). Vervolgens worden effecten van hoefdieren op de vegetatie besproken, met aandacht voor de verschillende hoefdiersoorten, waarbij de nadruk wordt gelegd op edelhert, ree en wild zwijn (hoofdstuk 3). De dynamiek van hoefdierpopulaties komt in hoofdstuk 4 aan de orde, gevolgd door een bespreking van de indicatoren waarmee wilddruk op de vegetatie kan worden geëvalueerd (hoofdstuk 5). Het beheer van hoefdierpopulaties in relatie tot hun effecten op de vegetatie wordt in hoofdstuk 6 besproken aan de hand van een aantal beheerscenario's. Uiteindelijk wordt in hoofdstuk 7 een aantal conclusies gepresenteerd naar aanleiding van het voorafgaande.

In dit rapport wordt gebruikgemaakt van twee begrippen om de mate van invloed, de 'druk', van hoefdieren op de vegetatie aan te geven: wanneer wordt gesproken over graasdruk of vraatdruk betreft het de invloed van vraat door hoefdieren aan de vegetatie. Met de term wilddruk wordt de invloed van de totale hoefdierpopulatie op de vegetatie en het landschap bedoeld met al haar verschillende effecten, zoals het afbijten van planten, schillen, vegen, wroeten, krabben, vertrappen, etc. 


\section{De Veluwe en Natura 2000-habitats}

\subsection{De Veluwe, een beknopte biografie}

\subsubsection{Bodemsubstraat en water}

De basis van de Veluwe bestaat uit gestuwde rivierafzettingen. Deze oude sedimenten variëren sterk in zandkorrelgrootte en leemgehalte en kunnen zelfs klei of grindbanken bevatten. Langs de flanken van de stuwwal zijn veel van de oorspronkelijk gelaagde sedimenten verspoeld en afgezet in de dalen. De minerale rijkdom varieert naar afkomst: afzettingen van de Rijn en Maas zijn relatief rijk, die van de oostelijke rivieren relatief arm (Neefjes, 2018; Jongmans et al., 2013).

In de laatste ijstijd werden de stuwwallen gedeeltelijk overstoven door leemarm dekzand, terwijl vooral langs de zuid-Veluwerand de wind lokaal ook sterk leemrijke löss heeft afgezet. Vanaf 1000 v.C., maar vooral in de middeleeuwen, degradeerde de vegetatie op de dekzanden en zijn door winderosie grote stuifzandcomplexen ontstaan (Pierik et al., 2018).

Op de hogere delen van de Veluwe is geen ondiep grondwater aanwezig, zodat de vegetatie afhankelijk is van het hangwater in de eerste meters van de bodem. Boven ondoorlatende lagen zoals klei en ijzeroerbanken kan een lokale grondwaterspiegel aanwezig zijn. Langs de flanken van de Veluwe ontspringen beeksystemen door uittredend grondwater, vaak verlengd via sprengenbeken.

\subsubsection{Vegetatie}

Tijdens de laatste ijstijd was de Veluwe een droge, vrijwel kale zandvlakte. Bij het stijgen van de temperatuur en neerslag kwam een kolonisatiegolf op gang van planten en dieren naar dit vrijkomende habitat. Er ontstond al snel een bosvegetatie, eerst gedomineerd door berken en dennen, later door de overige loofbomen die we nu als inheems beschouwen. Met de komst van de landbouw zijn deze bossen lokaal ontgonnen tot akkerland, vooral op de stuwwalgronden. Door overbegrazing en overbenutting is het bos uiteindelijk gedegradeerd tot heide en stuifzand. Dankzij een strikte bosbescherming door de oude maalschappen en jachthouders (met name de adel) bleven nog enkele kernen van oude bosgroeiplaatsen gespaard. In deze bossen werd eik sterk bevoordeeld vanwege de veelzijdigheid aan toepassingen. Vanaf het einde van de negentiende eeuw is steeds minder ingegrepen in de oude boskernen en is de beuk aan een grote opmars bezig. Dit zijn de habitats van het Beuken-eikenbos met hulst.

De heide was een zeer geschikte omgeving voor de vestiging van pioniers als berk en eik. Door de hoge veedruk, met name door schapen en runderen, werd de bebossing tegengegaan of sterk belemmerd. Desondanks konden lokaal boomrijke heiden ontstaan, die verder doorgroeiden tot eikenbossen. Veel stuifzandcomplexen bevatten een randwal, een steile, hoge heuvel waarin het zand is opgehoopt in een bosrand - al dan niet voor dat doel aangeplant - en waarin de aanwezige eiken verder als hakhout werden onderhouden. Op groeiplaatsen die voor 1850 reeds met bos (opgaand of in struikvorm) waren bedekt, vormen de resterende eikenbossen nu het habitattype Oude eikenbossen (Bijlsma et al., 2009).

Vanaf het einde van de negentiende eeuw zijn grote delen van de heide en stuifzanden beplant met bos. Hierbij is de grove den weer op grote schaal teruggebracht naar Nederland, nadat deze was verdrongen door de loofbomen in de voorgaande millennia. In de oude bossen werd een deel van de oorspronkelijke bosvegetatie (waarschijnlijk overwegend bestaand uit eikenhakhout of een vorm van middelhout) omgevormd naar andere boomsoorten. Naast grove den werden hier nieuwe soorten geïntroduceerd, zoals douglas, lariks, zwarte den, Amerikaanse eik en Amerikaanse vogelkers. 
De bodemvegetatie in de huidige bossen is overwegend soortenarm, vooral wat vaatplanten betreft. De oude boskernen bevatten een aantal typische bossoorten, waaraan veel van de botanische kwaliteit van deze bossen wordt afgemeten. In de ontginningsbossen ontbreken deze soorten meestal, en vinden we vooral soorten die ook onderdeel uitmaken van het heidelandschap. Overigens zijn ook veel van de bossoorten afhankelijk van regelmatige verstoring in het kronendak om zich te kunnen handhaven, en vaak duidt de aanwezigheid van oud bossoorten op een historische, meer open bosvegetatie. Oude bossen zijn verder een hotspot voor mossen, korstmossen, paddenstoelen en insecten, vooral wanneer er liggend en staand dood hout aanwezig is.

\subsubsection{Grote herbivoren}

In het nabije verleden hebben de populaties van edelhert en wild zwijn sterk gefluctueerd waarbij ze periodiek zelfs (lokaal) zijn uitgestorven door overbejaging. Op verschillende momenten zijn hoefdieren uitgezet of bijgeplaatst, waarbij dieren uit verschillende delen van Europa naar de Veluwe zijn gebracht. Na de Tweede Wereldoorlog namen de populaties in aantal en verspreidingsgebied op de Veluwe toe als gevolg van beter beheer, oudere en meer diverse bossen en mildere winters (Broekhuizen et al., 2016). Het merendeel van de Veluwe is aangewezen als leefgebied voor het edelhert. Voor het wild zwijn zijn enkele gebieden binnen de Veluwe, met name landbouwenclaves, uitgerasterd en geldt aldaar een nulstandbeleid.

Reeën zijn door overbejaging historisch teruggedrongen tot de Veluwe. Vanaf de tweede helft van de negentiende eeuw nam de soort weer toe en kwam weer voor in de meeste bosgebieden in Oost- en Midden-Nederland. Indien de dichtheid aan hoefdieren toeneemt, is het ree de eerste die in de concurrentie met andere hoefdiersoorten de strijd verliest en terrein moet prijsgeven (zie bijvoorbeeld Smit et al., 1998; Cornelissen, 2017).

Het damhert is vanuit het Midden-Oosten in de zestiende eeuw richting Nederland gehaald. De eerste waarnemingen op de Veluwe betreffen dieren rondom Het Loo in de tweede helft van de negentiende eeuw. Daaropvolgend werden geleidelijk meerdere delen van de Veluwe bereikt, mede door menselijk handelen. Hoewel de soort in de jaren negentig als ongewenste exoot werd beschouwd, is die na protest alsnog tot inheemse soort verklaard en sinds 2002 wettelijk beschermd. Geleidelijk neemt op de Veluwe het aantal damherten in aantal en verspreidingsgebied toe. Rond de poortgebieden en op het Infanterie Schietkamp en het Nationale Park De Hoge Veluwe geldt een nulstandbeleid. Overige hoefdieren op de Veluwe betreffen de wisent en semigedomesticeerde runder- en paardachtigen als Schotse hooglander, Exmoor-pony's etc. Daarnaast komen er lokaal moeflons en gedomesticeerde schaapskuddes voor.

Van oudsher was de Veluwe sterk versnipperd vanwege de vele grondeigenaren en/of jachtbelangen, met als gevolg vele rasters die de populaties sterk beperkten in hun actieradius. De Veluwe kende vijf deelgebieden van edelherten en acht deelgebieden van wilde zwijnen. Vanuit het ontsnipperingsprogramma Veluwe 2010 zijn vele ecoducten gecreëerd, zodat populaties hoefdieren beter kunnen uitwisselen. De kwaliteit van de leefgebieden is de afgelopen decennia verbeterd door een toename van het areaal, leeftijd en structuurvariatie van het bos. Veranderingen in het bosbeheer, afname van wildakkers en wildweides, mildere winters, toename van recreatie, toename van de wens om wild te kunnen zien en maatschappelijke betrokkenheid bij het welzijn van wild, spelen allemaal een rol in de aantallen, verspreiding, beheer en gedrag van hoefdieren op de Veluwe.

\subsubsection{Ontginning en huidige landschappelijke context}

De Veluwe is al millennia lang in gebruik door mensen, waardoor er vrijwel geen relicten meer zijn van autonoom ontwikkelde ecosystemen. Alle soorten zijn hier gekomen en hebben zich al dan niet gehandhaafd onder invloed van een dynamiek die vooral door menselijk handelen werd gestuurd. Welke soorten, ecosystemen en landschappen zich hier zonder die invloed zouden hebben ontwikkeld, blijft merendeels speculatie, waarmee dit weinig aanknopingspunten biedt om als referentie te dienen voor het maken van keuzes in het beheer. 
Door de variatie in groeiplaatsen en (voormalig) landgebruik is de Veluwe een divers gebied. Bos is de meest algemene vegetatievorm en komt in veel hoedanigheden voor. De oude loofboskernen, en daarmee de boshabitattypen Beuken-eikenbossen met hulst en de Oude eikenbossen, liggen niet meer als grote eilanden in een open landschap, maar worden nu ingesloten door uitgestrekte, relatief jonge bossen waarin naaldbomen een dominante rol spelen. De relatie met het eerdere open heide- en stuifzandlandschap is vaak niet meer aanwezig. Voor de Oude eikenbossen geldt dit in iets mindere mate (beide boshabitattypen worden in paragraaf 2.2 en 2.3 verder gekarakteriseerd). Het bos wordt afgewisseld met heiden, stuifzanden en landbouwontginningen. Deze openingen in het landschap dragen sterk bij aan de esthetische aantrekkelijkheid van het gebied, vormen een habitat voor een deels eigen flora en fauna (inclusief Natura 2000-habitattypen) en zijn een integraal onderdeel van het leefgebied van grote herbivoren.

De huidige ecosystemen zijn aan grote veranderingen onderhevig: klimaatverandering, introducties van nieuwe soorten, habitatversnippering, veranderingen in landgebruik et cetera hebben ertoe geleid dat de samenstelling en dynamiek van deze ecosystemen steeds meer afwijken van de situatie zoals die zich voordeed voor de industriële revolutie. Men spreekt daarom wel over 'novel ecosystems' (Hobbs et al., 2013), ecosystemen die dermate zijn veranderd als gevolg van menselijk beïnvloeding dat er geen referentie bestaat om toekomstige ontwikkelingen uit af te leiden. Dit maakt het erg ingewikkeld, zo niet onmogelijk, om gefundeerde uitspraken te doen over de ontwikkelingen in landschap, vegetatie of fauna op de Veluwe onder bepaalde beheerscenario's. Voor een kwalitatieve beoordeling van ontwikkelingen kunnen we niet meer terugvallen op een vergelijk met historische situaties. Als alternatief kunnen we ons richten op kennis over ecosysteemprocessen en prognoses maken van de daaruit voortkomende vegetatiepatronen en bijbehorende fauna, en hun interacties.

De bodems in de stuwwalgronden onder de Beuken-eikenbossen met hulst bestaan voor een groot deel uit bruine bosgronden (veelal aangeduid als holtpodzolen), vooral daar waar het zand leemrijk is. Op de armere zanden zijn de holtpodzolen al sterk aan het verzuren en vormen zich micropodzolen in de bovengrond, wat duidt op een ontwikkeling richting een echte zure podzol. Vooral op de heiden is deze verzuring vergevorderd. De Oude eikenbossen liggen op de armere dekzanden en stuifzanden. Op de plekken met een langere vegetatiegeschiedenis zijn haarpodzolen gevormd. Op de stuifzanden is de bodemvorming nog zeer jong (vaaggronden). Beide bodems zijn arm aan voedingsstoffen, zwak gebufferd en veelal sterk verzuurd. De dominantie in het bos van boomsoorten met slecht afbreekbaar strooisel zoals grove den, lariks, beuk en eik zorgt voor een verdere verzuring van de bodem. De depositie van vooral zwavel en stikstof heeft deze verzuring sterk versneld, waardoor veel bodems nu zeer arm zijn aan beschikbare basische kationen (calcium, magnesium, kalium) en er hoge concentraties aluminium en ammonium in het bodemvocht aanwezig zijn. Naast mitigerende maatregelen als bekalking of het toedienen van steenmeel (Bobbink et al., 2017; De Vries et al., 2019) wordt nu ook nadrukkelijk gekeken naar de rol van loofboomsoorten met beter afbreekbaar strooisel in het verminderen van de verzuring en het verbeteren van de beschikbaarheid aan basische kationen (Hommel et al., 2007; Maes et al., 2019; Desie et al., 2020). Boomsoorten die een dergelijke rol zouden kunnen spelen, ontbreken nu goeddeels in de huidige bossen. Een aantal daarvan, waaronder de wilde lijsterbes, komt wel voor, maar kunnen onder de huidige wilddruk geen onderdeel uitmaken van nieuwe bosgeneraties. Andere soorten, zoals linde, iep, boskers, vogelkers, gewone esdoorn, boswilg, veldesdoorn of ratelpopulier zijn in de afgelopen millennia uit het bosecosysteem verdreven of verdwenen en zouden moeten worden geherintroduceerd. Omdat dit vaak ook voor hoefdieren zeer smakelijke soorten zijn, is hun herintroductie onder de huidige wilddruk op veel plekken onmogelijk zonder fysieke bescherming. 


\subsection{H9120: Beuken-eikenbossen met hulst}

\subsubsection{Algemene karakterisering}

Het habitattype 'Zuurminnende Atlantische beukenbossen met Ilex en soms ook Taxus in de ondergroei (Quercinion robori-petraeae of Ilici-Fagenion)' (H9120) wordt in dit rapport verder benoemd als 'Beukeneikenbossen met hulst'. Het habitattype komt in Europa voor in de Atlantische zone, van Noord-Spanje tot aan Denemarken (Figuur 1). Beuk is de dominante soort, maar het habitattype kan ook uit eikenbos bestaan. Door natuurlijke successie zullen deze eikenbossen zich langzaam tot beukenbos ontwikkelen. Op Europees niveau worden als karakteristieke soorten gegeven: hulst (Ilex aquifolium), taxus (Taxus baccata), muizendoorn (Ruscus aculeatus), bochtige smele (Deschampsia flexuosa), boshavikskruid (Hieracium sabaudum), schermhavikskruid (H. umbellatum), adelaarsvaren (Pteridium aquilinum), blauwe bosbes (Vaccinium myrtillus), kamperfoelie (Lonicera periclymenum), hengel (Melampyrum pratense), valse salie (Teucrium scorodonia) en gladde witbol (Holcus mollis) (Europese Commissie, 2013).
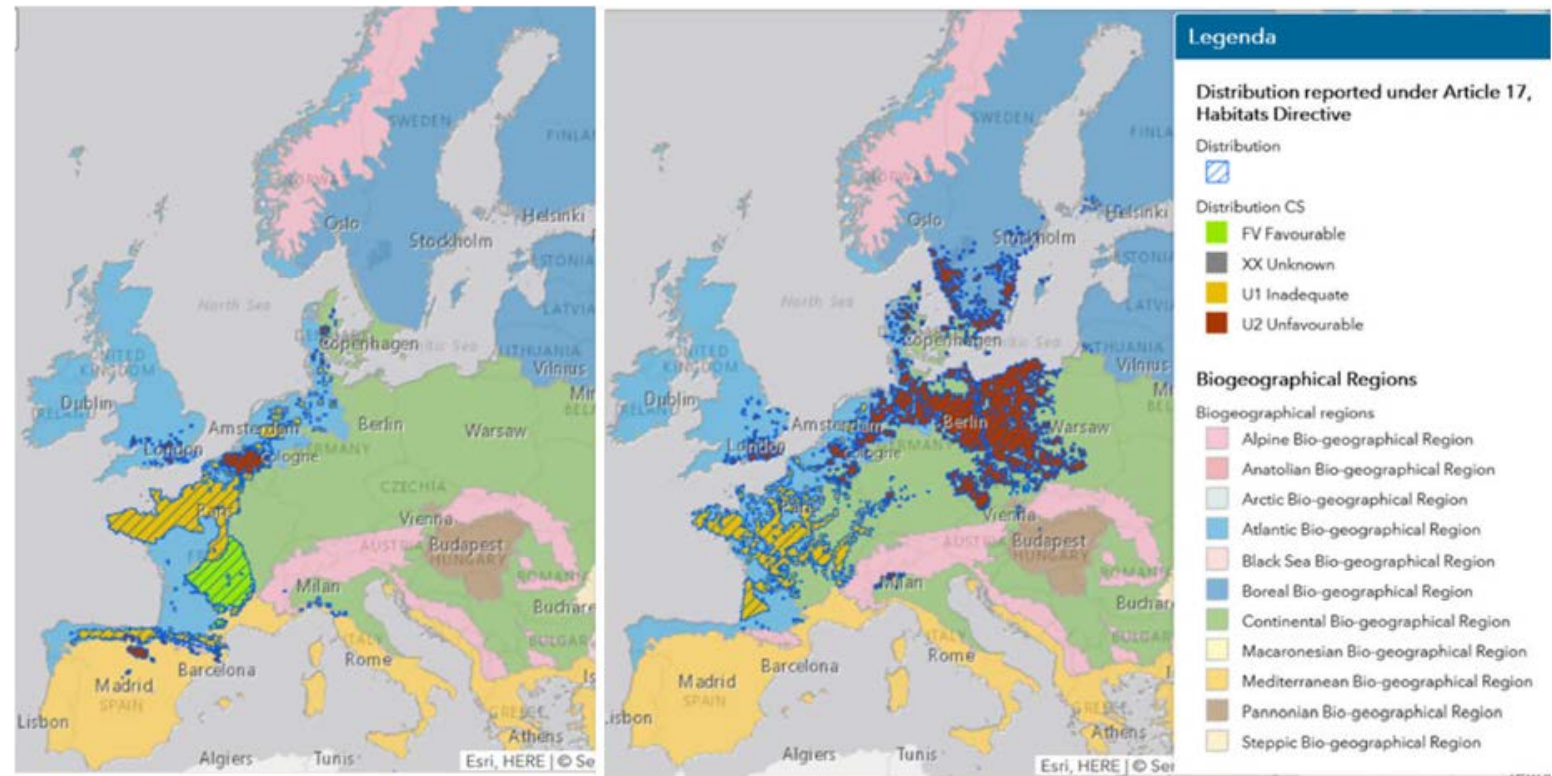

Figuur 1 Het voorkomen van habitattypen Beuken-eikenbossen met hulst (H9120; links) en Oude eikenbossen (H9190; rechts) en de biogeografische regio's in Europa. Kleuren geven de staat van instandhouding aan in 2018 (groen = gunstig/favourable, geel = matig ongunstig/inadequate, rood = zeer ongunstig/unfavourable). De Atlantische zone is weergegeven in lichtblauw, de Continentale zone in groen. (Bron: European Environmental Agency (2019).)

Voor Nederland zijn afbakening en kwaliteit van Beuken-eikenbossen met hulst gedefinieerd in het profielendocument (LNV 2008). In Nederland komt het habitattype vooral voor op de hogere zandgronden van de Veluwe, Achterhoek, Drenthe, Brabant en Limburg (Figuur 2). Voor Gelderland is de karakterisering van de Beuken-eikenbossen met hulst verder uitgewerkt door Bijlsma et al. (2008). Het habitattype beperkt zich tot de relatief rijkere zandgronden. Op de Veluwe zijn dit vooral de leemhoudende stuwwalgronden en oude voormalige landbouwgronden. Vanwege de karakterisering van het habitattype op basis van het voorkomen van een aantal typische oud-bossoorten (zoals adelaarsvaren, hengel en valse salie) beperkt het areaal Beuken-eikenbossen met hulst zich tot oude bosgroeiplaatsen (van voor 1850) of tot aangrenzende bossen op jongere bosgroeiplaatsen met bomen van minstens 100 jaar oud. Kwalificerende bossen hebben beuk of eik als hoofdboomsoort. Vanwege de ouderdom en de dominantie van soorten met slecht afbreekbaar strooisel hebben Beuken-eikenbossen met hulst meestal een dik humusprofiel. Op relatief rijke bodem, met name die met veel leem, is het humusprofiel dunner door activiteit van bodemfauna. Deze bodems zijn minder zuur en er treedt minder uitspoeling op (Bijlsma et al., 2008). Naast verschillen in de ondergrond kan ook het bijmengen van boomsoorten met beter afbreekbaar strooisel leiden tot een rijkere humusvorming met een hogere beschikbaarheid van basische kationen (Desie et al., 2020). 
Het relatieve belang van Nederland in de verspreiding van Beuken-eikenbos met hulst in Europa is groot, evenals het relatieve belang van de Veluwe in het voorkomen van het habitattype binnen Nederland (Bijlsma et al., 2008).
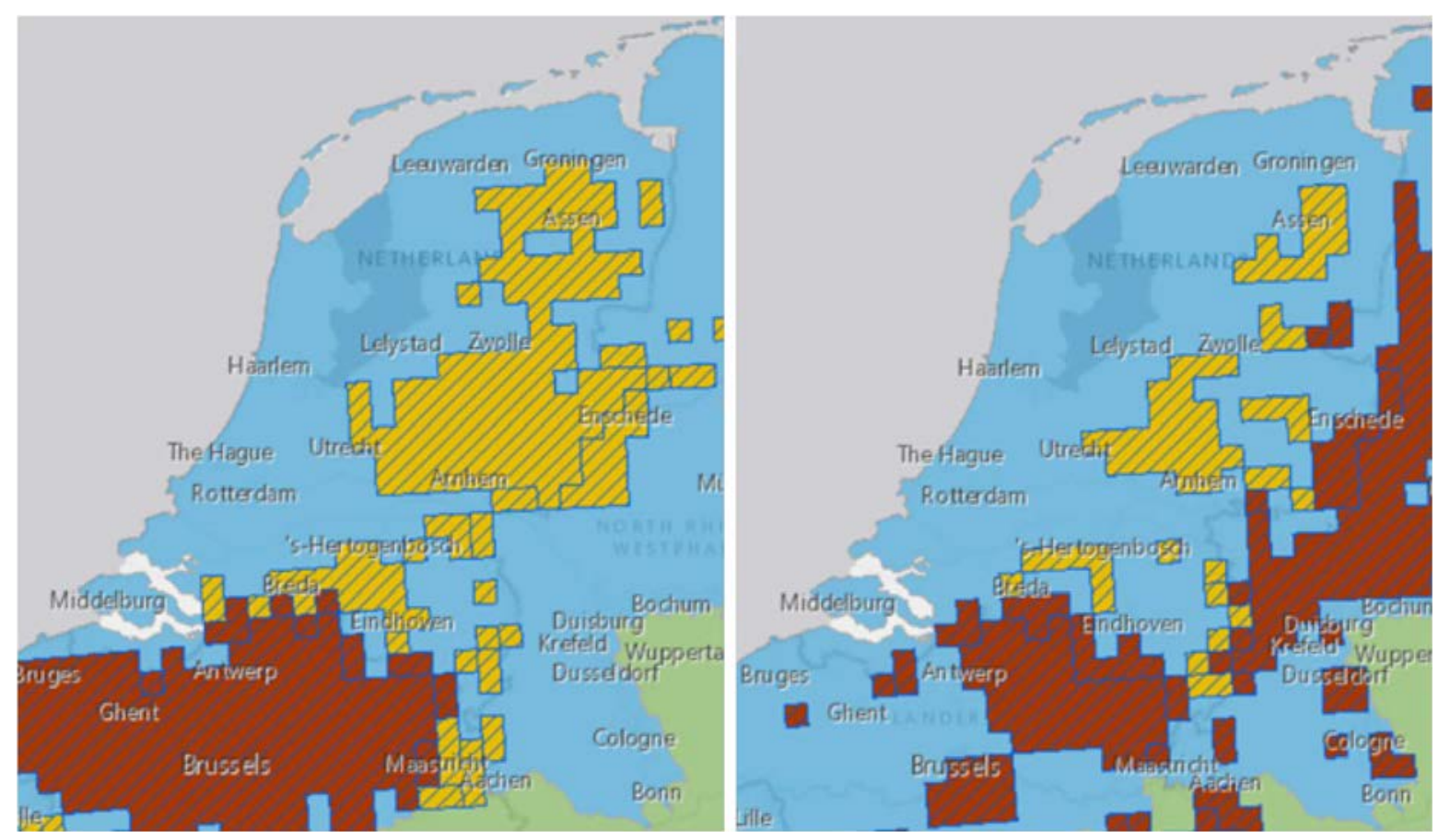

Figuur 2 Het voorkomen van habitattypen Beuken-eikenbossen met hulst (H9120; links) en Oude eikenbossen (H9190: rechts) in Nederland. Voor legenda: zie Figuur 1. Bron: European Environmental Agency (2019).

\subsubsection{Dynamiek}

De soortensamenstelling en structuur van de aangewezen habitattypen Beuken-eikenbossen met hulst zijn de afgelopen eeuwen sterk door beheer beïnvloed. Vooral de dominantie van eik is het gevolg van het voortdurend bevoordelen van deze soort als bron van hout, looistoffen en voedsel. Door de regelmatige verstoringen in het bos was de bosstructuur open, waardoor een gevarieerde ondergroei zich kon handhaven. Eiken werden vooral beheerd als hakhout, maar veel van de oude boskernen op de Veluwe dragen sporen van een vorm van middelhout, waarin ook opgaande eiken en beuken groeiden (Veen et al., 2017). Door natuurlijke successie heeft de beuk de afgelopen eeuw sterk aan terrein gewonnen ten koste van de eik en andere boomsoorten die in het bos aanwezig waren. Berken, iepen en populieren die in oude malenboeken worden genoemd (Hacke-Oudemans, 1969), zijn vrijwel geheel verdwenen. 


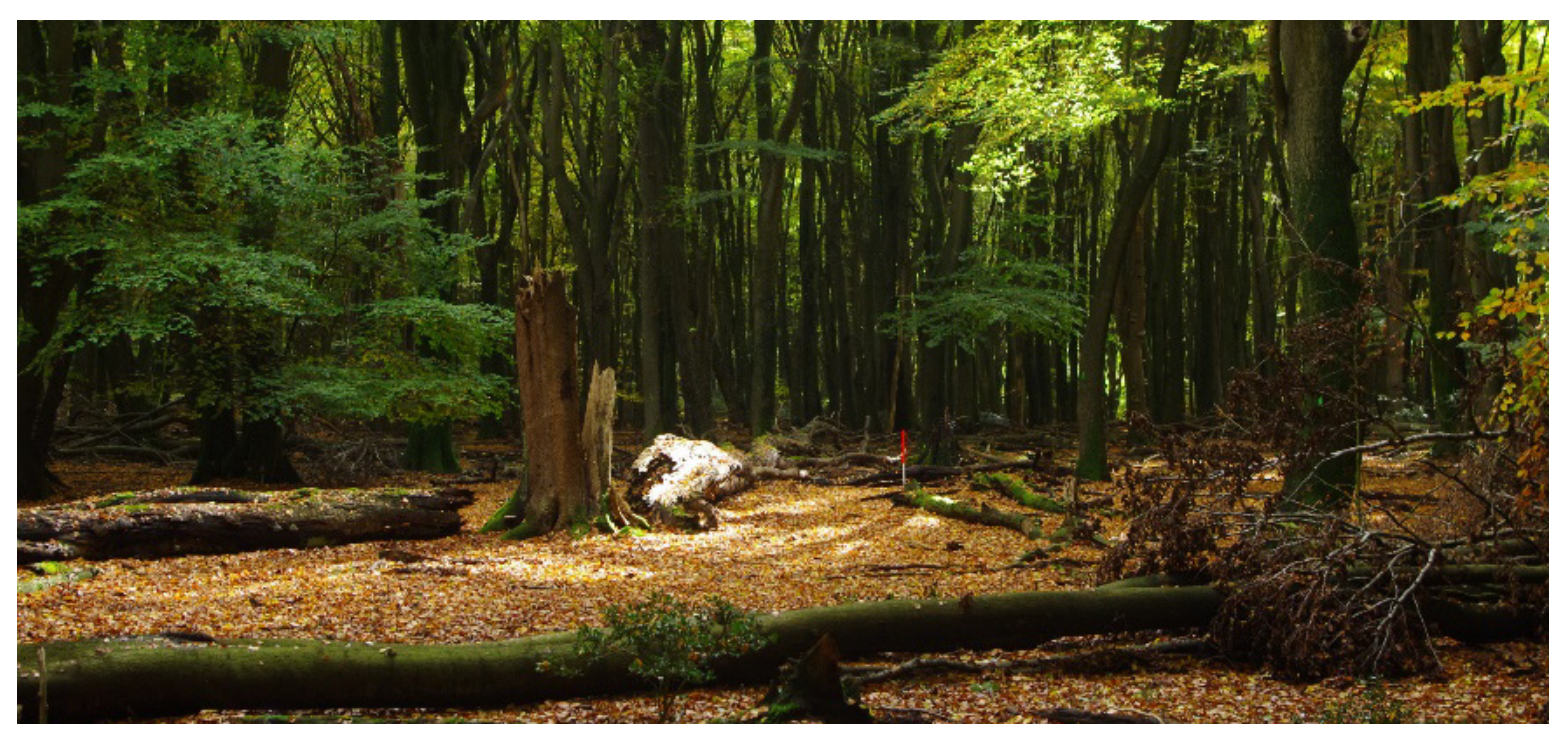

Figuur 3 Het sterk door beuk gedomineerde Beuken-eikenbos met hulst in het bosreservaat Pijpebrandje in het Speulderbos bij Garderen.

Beuken-eikenbossen met hulst kennen een lage natuurlijke dynamiek. Windworp vormt de belangrijkste verstoring, maar treedt vooral kleinschalig op, zodat beuk en andere schaduw verdragende soorten - zoals hulst - de verjonging domineren (Figuur 3). Incidenteel kunnen bij zware stormen of onweersbuien grotere stormvlaktes ontstaan waar zich ook meer licht behoevende boomsoorten kunnen vestigen. Van oudsher werd vee uit het bos geweerd om de verjonging van bomen niet te belemmeren (Hacke-Oudemans 1969; Horst 2011). De afgelopen decennia is de wilddruk in veel bossen sterk toegenomen, waardoor de spontane verjonging van vooral loofbomen wordt belemmerd (zie o.a. Kuiters \& Slim, 2002).

\subsubsection{Kwaliteitskenmerken}

In het profielendocument (LNV 2008) wordt de kwaliteit van het habitattype Beuken-eikenbossen met hulst gedefinieerd als bossen voorkomend op matig zure tot zure, vochtige tot droge, zeer voedselarme tot licht voedselrijke bodems. Als typische soorten worden genoemd: Maleboskorst (Lecanactis abietina), Hazelworm (Anguis fragilis ssp. fragilis), Dalkruid (Maianthemum bifolium), Gewone salomonszegel (Polygonatum multiflorum), Lelietje-van-dalen (Convallaria majalis), Witte klaverzuring (Oxalis acetosella), Boomklever (Sitta europaea ssp. caesia) en Zwarte specht (Dryocopus martius ssp. martius). Voor de structuur geldt dat op landschapsschaal soortenrijke open plekken en bosranden met plantensoorten uit de klasse Melampyro-Holcetea mollis of bijzondere braamsoorten (Rubus) aanwezig zijn, er oude levende of dode dikke bomen en/of oude hakhoutstoven voorkomen en dat de omvang van individuele habitats vanaf tientallen hectares groot is.

In Bijlsma et al. (2008) zijn de kwaliteitseisen uit het profielendocument (LNV, 2008) nader uitgewerkt voor de provincie Gelderland en worden de ruimtelijke samenhang en het oppervlak van habitattypen, de structuur van het habitattype en de voorkomende flora en fauna als kwaliteitscriteria nader beschreven. Het voorkomen van hoefdieren heeft geen effect op het eerste criterium. Het oppervlak van habitattypen zou wel kunnen worden beïnvloed door hoefdieren wanneer hun effect dermate grote gevolgen heeft voor de habitat dat delen daarvan niet meer kwalificeren als habitattype. Dit zou dan zijn oorzaak hebben in een verandering van de structuur en voorkomende flora en fauna, met name de dominantie van beuk en eik op de langere termijn. De effecten van hoefdieren op de kwaliteit van habitattypen zal dus verder worden uitgewerkt aan de hand van mogelijke effecten op de structuurkenmerken en het leefgebied en voorkomen van soorten en de verjongingsmogelijkheden van boomsoorten. Dit geldt ook voor het habitattype Oude eikenbossen. 


\section{Structuur}

De aanwezigheid van oude, dikke bomen en dood hout geldt als belangrijkste structuurkenmerk voor Beuken-eikenbossen met hulst. Deze kenmerken, behorend bij oude bossen, komen nog beperkt voor, maar zijn cruciaal voor de aan bos gebonden biodiversiteit in het algemeen en het boshabitattype Beuken-eikenbossen met hulst in het bijzonder. Voor de verbetering van de structuurkenmerken in dit habitattype is vooral veel tijd nodig en een beheer waarin het behoud van oude bomen en dood hout een centraal aandachtspunt vormt. Hoefdieren hebben hier verder geen effect op.

De structuurkwaliteit van het Beuken-eikenbos met hulst wordt verder als goed beoordeeld wanneer sprake is van een heterogene structuur met natuurlijke verjonging en afwezigheid van exoten. In Bijlsma et al. (2008) wordt begrazing door hoefdieren nader benoemd als belangrijk voorwaardelijk mechanisme voor het in standhouden van open plekken. Hoefdieren dragen hiermee bij aan een heterogene horizontale structuur (afwisseling van bosontwikkelingsfasen). Op de open plekken ontstaan gunstige groeicondities voor de verschillende plantengemeenschapen van struwelen en bosranden die in het profielendocument genoemd worden als representatief onderdeel van het habitattype.

In Bijlsma et al. (2008) wordt de aanwezigheid van hoefdieren als gunstig voor de habitat beoordeeld, want "begrazing door grote herbivoren vertraagt de successie en voorkomt de ontwikkeling van een uniforme structuur (gelaagdheid)". Dit roept de vraag op welke wilddruk hiervoor nodig is en wat daarvan de gevolgen zijn voor de samenstelling en de dichtheid van de verjonging van boomsoorten. Bij de beoordeling van de staat van instandhouding speelt de aanwezigheid van loofboomsoorten of aanwezigheid van bosverjonging in algemene zin geen enkele rol voor het vaststellen van de kwaliteit van het habitattype (Janssen et al., 2020). Voor de kwalificering als habitattype Beuken-eikenbos met hulst is het op de langere termijn echter wel van belang dat de dominantie van beuk en eik gehandhaafd blijft en de aan het bosmilieu gekoppelde vegetatietypen. De daarvoor benodigde verjonging wordt in de insteek van de provincie Gelderland expliciet als kwaliteitskenmerk genoemd (zie Bijlage 1). Daarbij gaat het niet alleen om de definiërende (beuk, eik) en naamgevende (hulst, taxus) soorten van het habitattype, maar ook om begeleidende soorten als wilde lijsterbes en vuilboom die in de verjongingsfase van het bos een rol spelen, evenals andere pioniersoorten als berk, ratelpopulier en boswilg.

\section{Flora en Fauna}

Voor het vaststellen van de kwaliteit van een bepaald gebied als habitattype wordt gebruikgemaakt van lijsten met kwaliteitssoorten en bijzondere kwaliteitssoorten. De hiernavolgende definities komen uit Bijlsma et al. (2008): Kwaliteitssoorten zijn "vrij algemene tot (vrij) zeldzame soorten die kwaliteit indiceren". In het geval van Beuken-eikenbossen met hulst betreffen deze vooral oud-bosindicatoren. Bijzondere kwaliteitssoorten zijn "soorten die een speciale kwaliteit vertegenwoordigen, omdat ze landelijk (zeer) zeldzaam zijn of een regionale of anderszins specifieke en zeldzame vorm van het habitattype representeren". Voor de Beuken-eikenbossen met hulst is een lijst samengesteld van dieren, paddenstoelen, (korst)mossen en vaatplanten die als (bijzondere) kwaliteitssoort worden aangemerkt. In dit rapport ligt de nadruk vooral op de groep vaatplanten, die worden vermeld in Tabel 1. Twee in het profielendocument van LNV (2008) als typische vaatplanten genoemde soorten zijn niet als kwaliteitssoort opgenomen, omdat zij twijfelachtig inheems zijn (lelietje-van-dalen) of geen duidelijke relatie hebben met oud-bosgroeiplaatsen (gewone salomonszegel). 
Tabel 1 De kwaliteitssoorten en bijzondere kwaliteitssoorten binnen de vaatplanten van Beukeneikenbossen met hulst in Gelderland (uit Bijlsma et al. (2008)). Tevens aangegeven [1] welke soorten als typische soorten voor het habitattype zijn gedefinieerd (naar Bijlsma et al., 2008) en [2] welke soorten expliciet worden genoemd als karakteristiek voor de kruidlaag in de insteek Provincie Gelderland (Bijlage 1).

\begin{tabular}{llll} 
Kwaliteitssoorten & & Bijzondere kwaliteitssoorten \\
Boshavikskruid & Hieracium sabaudum & Bosanemoon & Anemone nemorosa \\
\hline Dicht havikskruid & Hieracium vulgatum & Fraai hertshooi & Hypericum pulchrum \\
\hline Dalkruid ${ }^{1,2}$ & Maianthemum bifolium & Ruige veldbies & Luzula pilosa \\
\hline Hengel & Melampyrum pratense & Boswederik & Lysimachia nemorum \\
\hline Witte klaverzuring ${ }^{1,2}$ & Oxalis acetosella & Wilde appel & Malus sylvestris \\
\hline Bladhumusbraam & Rubus foliosus & Tere woudbraam & Rubus invenis \\
\hline Donkere bosbraam & Rubus silvaticus & Sierlijke woudbraam & Rubus pedomontanus \\
\hline Fraaie kambraam & Rubus vestitus & Echte guldenroede & Solidago virgaurea \\
\hline Valse salie ${ }^{2}$ & Teucrium scorodina & Grote muur & Stellaria holostea \\
\hline Bleeksporig bosviooltje & Viola riviniana & Zevenster & Trientalis europaea \\
\hline Gewone eikvaren & Polypodium vulgare & &
\end{tabular}

De meeste overige florasoorten die als (bijzondere) kwaliteitssoorten of typische soorten worden aangemerkt zijn indicatoren voor oud bos en dood hout, zoals een aantal doodhoutpaddenstoelen, mossen en korstmossen (met maleboskorst als typische soort). Als belangrijke fauna worden ook vooral soorten genoemd die gerelateerd zijn aan het voorkomen van oude bomen (vleermuizen, boommarter en de typische soorten zwarte specht en boomklever) en verder aan hoog opgaand loofbos (appelvink, wielewaal), rijk gestructureerd bos (wespendief) en eiken (de eikenpage en bruine eikenpage). Hoefdieren hebben geen directe invloed op het voorkomen van deze soorten (zie Bijlsma et al., 2008 voor alle genoemde soorten). De twee diersoorten die mogelijk wel direct beïnvloed kunnen worden door hoefdieren, met name door wild zwijn, zijn de hazelworm (typische soort voor het habitattype) en het vliegend hert (bijzondere kwaliteitssoort). 


\subsection{H9190: Oude eikenbossen}

\subsubsection{Algemene karakterisering}

Het habitattype 'Oude zuurminnende eikenbossen op zandvlakten met Quercus robur' (H9190) wordt in dit rapport verder benoemd als 'Oude eikenbossen'. Het habitattype komt voor van Zuid-Frankrijk tot Zuid-Scandinavië en verder oostwaarts tot in Polen (Figuur 1). Oude eikenbossen groeien op zure en arme zandgronden en bestaan uit zomereik (Quercus robur), soms ook wintereik (Quercus petraea), ruwe en zachte berk (Betula pendula en $B$. pubescens), met bijmenging van wilde lijsterbes (Sorbus aucuparia) en ratelpopulier (Populus tremula). De struiklaag is slecht ontwikkeld en de ondergroei wordt gedomineerd door grassen en kruiden van arme zandbodems. Adelaarsvaren kan lokaal tot dominantie komen, maar dit is, evenals braam, meest voorbehouden tot voormalige hakhoutbossen op lemiger materiaal, hetgeen vaak een aanwijzing is dat het groeiplaatsen betreft van het Beuken-eikenbos met hulst. Als karakteristieke soorten op Europees niveau worden de hierboven gegeven boomsoorten genoemd (Europese Commissie, 2013).

Voor Nederland zijn afbakening en kwaliteit van de Oude eikenbossen gedefinieerd in het profielendocument (LNV 2008). Het habitattype komt vooral voor op de Veluwe en in Drenthe en hebben een sterke relatie met het heide- en stuifzandlandschap (Figuur 2). Zij komen voor in verschillende varianten (Bijlsma et al., 2009; zie Figuur 4). De meeste Oude eikenbossen treffen we aan als ingestoven bossen in en langs de rand van stuifzandcomplexen. Het stuivende zand is daarbij in het bos tot rust gekomen. Hierbij zijn in een aantal gevallen hoge randwallen ontstaan. Daarnaast komen Oude eikenbossen voor als zogenaamd strubbenbos, dat is ontstaan in een sterk begraasd landschap, waarvan de regelmatig voorkomende eikenclusters een getuigenis vormen (Den Ouden et al., 2009). Zodra zich een duidelijke eikenvegetatie ging vormen, kon deze worden beschermd tegen het vee en tot hakhoutbossen worden omgevormd (Hacke-Oudemans 1969). Beide typen betreffen oude bosgroeiplaatsen en kwalificatie is afhankelijk van de ouderdom van de bosgroeiplaats (aanwezig voor 1850). Ook aangeplant eikenbos op arm moedermateriaal als ontginningsbos wordt tot de Oude eikenbossen gerekend, mits de bomen ouder zijn dan 100 jaar (Bijlsma et al., 2008).
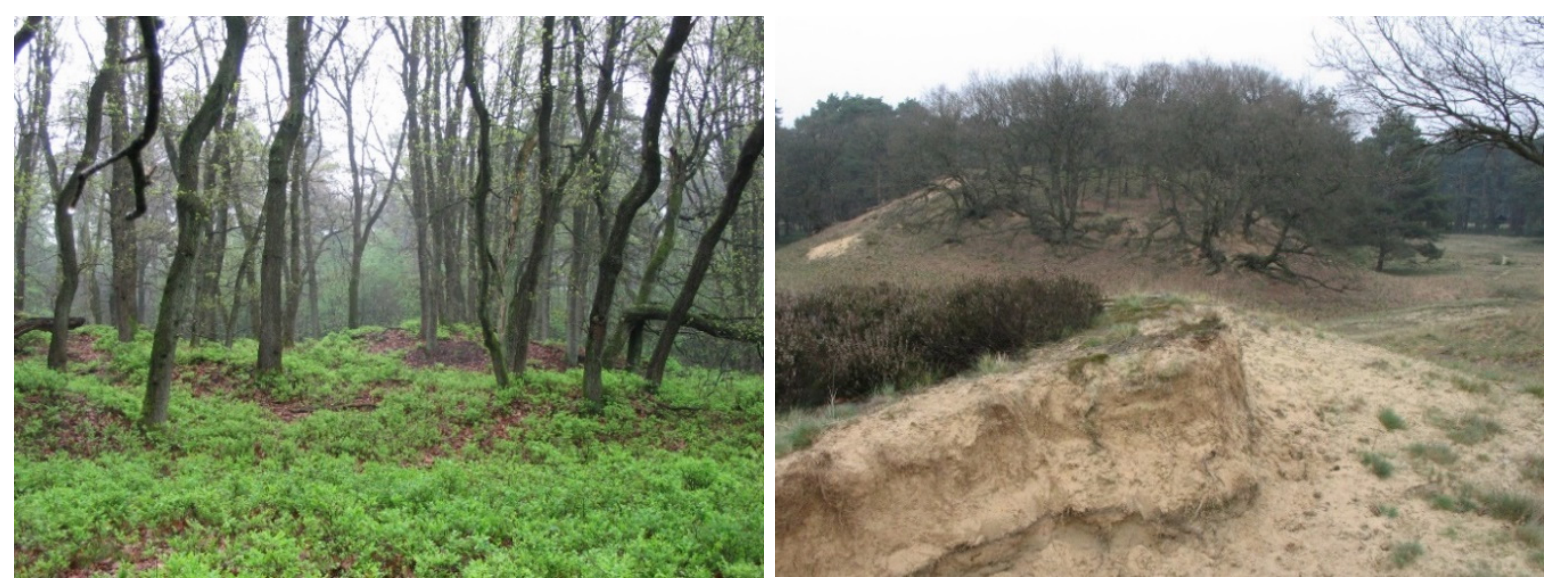

Figuur 4 Twee verschijningsvormen van het habitattype Oude eikenbossen op de Veluwe. Links een strubbenbos in een voormalig stuifzand bij Nieuw-Milligen met een dichte ondergroei van blauwe bosbes. Rechts een randwal langs Deelen, met eeuwenoude eiken in het Nationale Park De Hoge Veluwe. 


\subsubsection{Dynamiek}

De historische dynamiek van Oude eikenbossen is vooral afhankelijk van hun ontstaansgeschiedenis. De ingestoven eikenbossen kenden aanvankelijk een hoge dynamiek als gevolg van de regelmatige overstuivingen. Daarbij werden de ingestoven stammen en kronen vaak afgezet als hakhout om als struiklaag een nog betere invang van zand te kunnen realiseren. Ook werd eik wel bijgeplant om als zandvang te dienen. De strubbenbossen hebben sterk onder invloed gestaan van begrazing door vee, en zijn waarschijnlijk ook wel incidenteel als bron van hout geëxploiteerd, maar dit zal door de vaak afgelegen ligging weinig structureel hebben plaatsgevonden. De strubbenbossen worden daarom wel als onze meest natuurlijke eikenbossen gezien (Bijlsma et al., 2009). De eikenbossen die als hakhoutcomplexen zijn aangelegd op de heide, hebben een weinig natuurlijke oorsprong en zijn altijd erg beïnvloed geweest door menselijk handelen.

Over het algemeen speelt begrazing een belangrijke rol in dit habitattype, waardoor de kenmerkende openheid van het bos veelal is gehandhaafd. Door begrazing werd - en wordt - de opslag van een struiklaag voorkomen, waardoor een dichte bodemvegetatie kan ontstaan van blauwe bosbes of grassen (zie Figuur 4). Daar waar de eiken een gesloten kronendak hebben kunnen vormen, is de bodemvegetatie meestal minder sterk ontwikkeld.

In eikenbossen verjongt de eik zich nauwelijks tot niet. Vaak wordt hierbij gewezen naar begrazing als belangrijkste oorzaak, maar dat is slechts ten dele het geval. De dominantie van eik is ontstaan vanuit een open landschap, waarin eik zich vrij kon vestigen in de heide, of is het gevolg van gerichte aanplant en verzorging. Eik is een echte pioniersoort en is afhankelijk van open habitats om zich succesvol te kunnen verjongen (Bobiec et al., 2018). Bij het sluiten van het kronendak wordt het milieu voor eikenverjonging dus ook ongunstig en voortgaande successie zal leiden tot een toename van meer schaduw verdragende soorten.

Veel van de Oude eikenbossen ondervinden niet meer de stuifzandinvloed van weleer. In de afgelopen eeuw zijn actieve verstuivingen sterk afgenomen en heidevelden grotendeels ingeplant met bos. Dit betekent dat de verjongingsmogelijkheden voor eik sterk zijn ingeperkt. Uitbreiding van het habitattype zou gerealiseerd kunnen worden in de resterende open stuifzand- en heidegebieden, maar deze zijn op hun beurt aangewezen als prioritair habitat. Op droge heide kan door vestiging van eik een 'boomheide' ontstaan, wat niet tot kwaliteitsverlies leidt van de heide, mits het kroonbedekkingspercentage lager blijft dan 10. Bij een verdere verdichting van een dergelijke vegetatie zal dit wel leiden tot kwaliteitsverlies van de droge heide (H4030). In het geval de uitbreiding van het habitattype Oude eikenbossen niet ten koste mag gaan van het areaal droge heide, is uitbreiding van het areaal Oude eikenbossen alleen nog mogelijk in zeer lichte bossen, zoals die van grove den, waarin eik zich nog wel kan verjongen, of door actieve omvorming van andere bostypen naar eik.

De kwaliteit van de Oude eikenbossen wordt, evenals die van de Beuken-eikenbossen met hulst, sterk aangetast door de voortgaande depositie van stikstof. Bodemverzuring en het daarmee gepaard gaande verlies aan basische kationen leiden samen met een overmaat aan stikstof tot grote vitaliteitsproblemen van eik. Veel van de huidige Oude eikenbossen vertonen grote sterfte (De Vries et al., 2019) waardoor hun voortbestaan sterk wordt bedreigd, temeer daar de verjonging in deze degraderende bossen mede als gevolg van begrazing vaak gedomineerd wordt door naaldbomen (Figuur 5). 


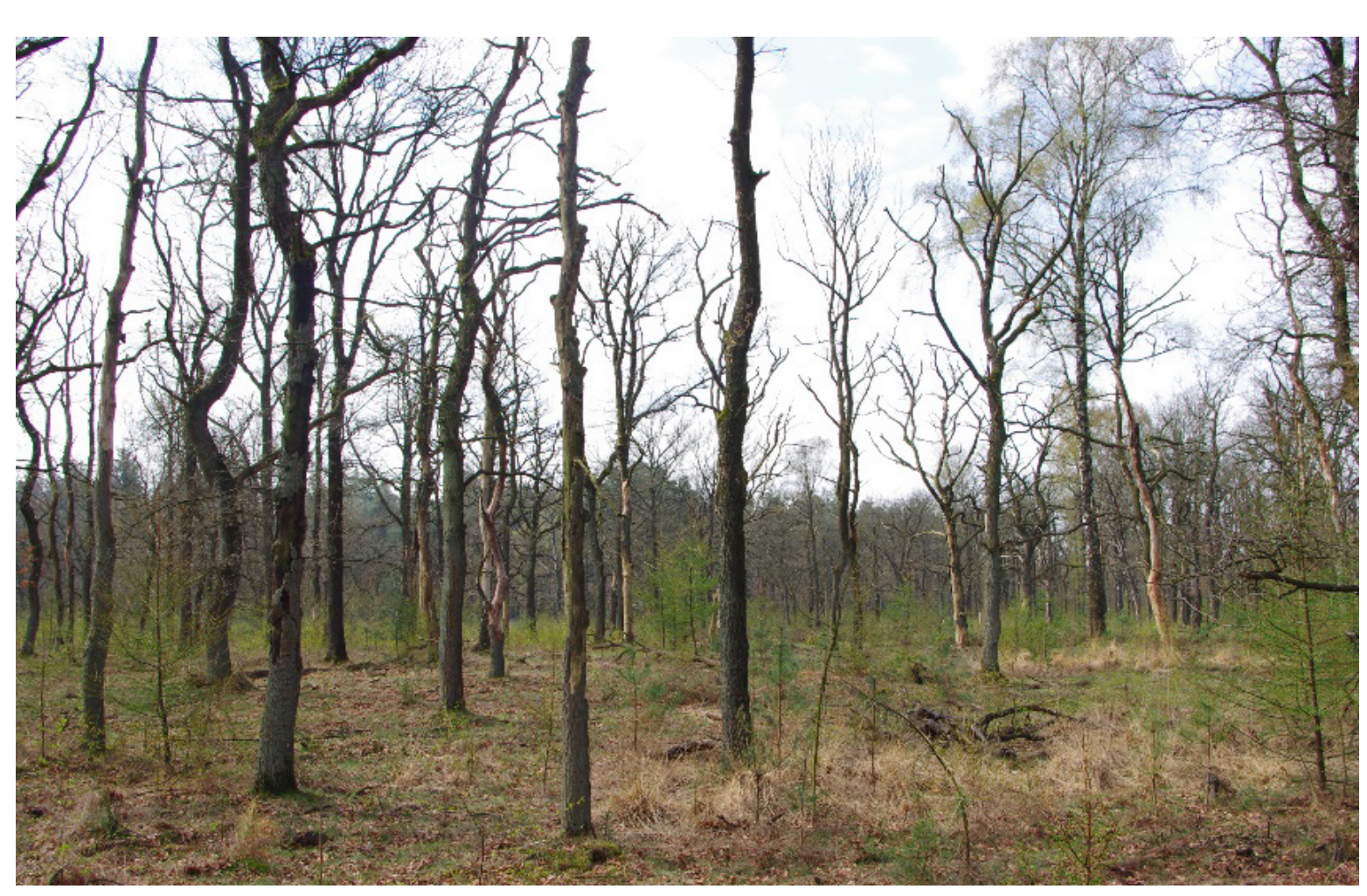

Figuur 5 Degraderend Oud eikenbos op de Kemperberg (Nationale Park De Hoge Veluwe). Massale sterfte van eik zorgt voor ideale verjongingsmogelijkheden voor eik en ander loofboomsoorten, maar door een hoge wilddruk bestaat de verjonging grotendeels uit naaldbomen (voornamelijk Japanse lariks en enige grove den).

\subsubsection{Kwaliteitskenmerken}

In het profielendocument (LNV 2008) wordt de kwaliteit van het habitattype Oude eikenbossen gedefinieerd als bossen voorkomend op zure, (zeer)vochtige tot droge, zeer (tot matig) voedselarme bodems. Als typische soorten worden genoemd: Eikenpage (Neozephyrus quercus), Kussentjesmos (Leucobryum glaucum), Hanenkam (Cantharellus cibarius), Regenboogrussula (Russula cyanoxantha), Smakelijke russula (Russula vesca), Zwavelmelkzwam (Lactarius chrysorrheus), Hengel (Melampyrum pratense), Matkop (Parus montanus ssp. rhenanus) en Wespendief (Pernis apivorus). Voor de structuur geldt dat de habitat een zeer open structuur heeft, een goed ontwikkelde moslaag en/of korstmoslaag, er dood hout op de bosbodem aanwezig is en dat voor een optimaal functioneren een individuele habitat minimaal enkele tientallen hectares groot is. In Bijlsma et al. (2008) zijn deze kwaliteitseisen uit het profielendocument (LNV 2008) nader uitgewerkt voor de provincie Gelderland.

Evenals voor Beuken-eikenbossen met hulst geldt voor Oude eikenbossen dat ruimtelijke samenhang en oppervlakte niet direct worden beïnvloed door hoefdieren. Wel kan het areaal uiteindelijk worden verkleind wanneer de boomsoortensamenstelling dermate zou worden beïnvloed door hoefdieren dat delen van het bos niet meer kwalificeren als habitattype.

\section{Structuur}

Door hun ontstaansgeschiedenis kenmerken de meest Oude eikenbossen zich als relatief open bossen met een ondergroei van dwergstruiken en grassen. Als structuurindicatoren worden in Bijlsma et al. (2008) de natuurlijkheidsgraad en de afwezigheid van schaduwboomsoorten en exoten genoemd. De natuurlijkheidsgraad betreft vooral een historisch kenmerk en wordt niet direct door hoefdieren beïnvloed. Als onderdeel van de natuurlijkheidsgraad worden verder een heterogene structuur genoemd en aanwezigheid van open ruimten. Begrazing spelt hierbij een rol, maar hiervoor gelden met het oog op de verjonging dezelfde opmerking als bij de structuurkenmerken van het Beuken-eikenbos met hulst (zie 2.2.3). De kwaliteit van Oude eikenbossen wordt als goed beoordeeld, zolang schaduw werpende boomsoorten als de beuk en exoten niet opvallend aanwezig zijn. Is dit wel het geval, dan wordt de kwaliteit als basaal beoordeeld. Hoefdieren kunnen hier een sturende rol in spelen. 


\section{Flora en fauna}

Als (bijzondere) kwaliteitssoorten wordt een aantal epifytische korstmossen genoemd, evenals een aantal (lever)mossen die niet direct door hoefdieren worden beïnvloed. Wellicht gaat het intensief wroeten door wild zwijn ten koste van bodemmossen, zoals de typische soort kussentjesmos (Bijlsma et al., 2008). Dit geldt ook voor de verschillende paddenstoelensoorten die als (bijzondere kwaliteitssoorten zijn aangemerkt. Dit zijn alle ectomycorrhizae-vormende soorten, zoals de als typische soorten gedefinieerde hanenkam, zwavelmelkzwam, regenboogrussula en smakelijke russula.

Qua vaatplanten bevat het habitattype Oude eikenbossen aanzienlijk minder kwaliteitssoorten dan het Beuken-eikenbossen met hulst (Tabel 2). Opvallend is dat de kwaliteitssoorten uit Oude eikenbossen alle ook als kwaliteitssoort voor het Beuken-eikenbos met hulst worden genoemd. Alleen stijf havikskruid is uniek voor eerstgenoemd habitattype.

Tabel 2 De kwaliteitssoorten en bijzondere kwaliteitssoorten binnen de vaatplanten van Oude eikenbossen in Gelderland. Typische soorten zijn aangeduid met [1]. Uit Bijlsma et al. (2008).

\begin{tabular}{|c|c|c|c|}
\hline \multicolumn{2}{|c|}{ Kwaliteitssoorten } & \multicolumn{2}{|c|}{ Bijzondere kwaliteitssoorten } \\
\hline Stijf havikskruid & Hieracium laevigatum & Zevenster & Trientalis europaea \\
\hline Adelaarsvaren & Pteridium aquilinum & & \\
\hline Hengel ${ }^{1}$ & Melampyrum pratense & & \\
\hline
\end{tabular}

Als (bijzondere) kwaliteit-indicerende diersoorten zijn in het Oude eikenbos, net als in het Beukeneikenbos met hulst, de eikenpage, bruine eikenpage en de als typische soort aangemerkte wespendief van belang. Ook de matkop is een typische vogelsoort in dit habitattype. Voor deze soorten is niet te verwachten dat hoefdieren een direct effect hebben op hun populaties. De bijzondere kwaliteitssoort bosparelmoervlinder kan wel direct worden beïnvloed via haar waardplant, hengel. Ook hiervoor vermelden Bijlsma et al. (2008) dat het woelen van wilde zwijnen negatief kan uitwerken op populaties, evenals voor de typische soorten hazelworm en het vliegend hert.

Voor Oude eikenbossen wordt geen enkele boomsoort als kwaliteitssoort genoemd, en naast de aanwezigheid van eik wordt de boomlaag verder niet gespecificeerd. Verjonging is geen onderdeel van de kwaliteitsbeoordeling voor het bepalen van de staat van instandhouding (Janssen et al., 2020). Ook voor het habitattype Oude eikenbossen is het voor de kwalificering als habitattype op de langere termijn van belang dat de dominantie van eik gehandhaafd blijft, inclusief bijbehorende vegetatietypen. De aanwezigheid van verjonging wordt in de insteek van de provincie Gelderland expliciet als kwaliteitskenmerk genoemd (zie Bijlage 1). Het betreft hier ook de begeleidende soorten wilde lijsterbes en vuilboom. Voor de kruidlaag worden met name havikskruiden, hengel en valse salie genoemd als kwaliteitssoorten (al is laatstgenoemde soort eerder kenmerkend voor bossen op wat rijkere bodem dan typisch Oude eikenbossen). In de insteek wordt expliciet aandacht besteed aan het typerende open karakter van Oude eikenbossen. 


\subsection{Interacties tussen grote herbivoren en boshabitats}

Hoefdieren zijn een natuurlijk onderdeel van het bosecosysteem. De samenstelling en dichtheid van hoefdierpopulaties heeft in het verleden sterk gefluctueerd, in afhankelijkheid van klimaat en vegetatieontwikkeling, en de afgelopen millennia in interactie met de mens (Sykes \& Putman, 2014). Door bejaging zijn soorten uitgestorven (oeros) of sterk gedecimeerd, terwijl de zeer ingrijpende veranderingen in het landschap (ontbossing, ontginning naar landbouw) de habitats voor hoefdieren sterk hebben gewijzigd.

Vooral in Nederland heeft er een discussie plaatsgehad over de vraag of de openheid van het landschap een 'natuurlijk' fenomeen is dat van oudsher ontstond en in stand werd gehouden door een hoge graasdruk (Vera, 2000) of dat de openheid het gevolg is van ontginning van een oorspronkelijk nagenoeg geheel bebost landschap (Louwe Kooijmans, 2017). In dit rapport wordt in deze discussie geen standpunt ingenomen, maar wordt uitgegaan van de huidige landschappelijke context en de wijze waarop de huidige boshabitattypen, en de daarin aanwezige hoefdieren, daarin functioneren.

Grote herbivoren worden gekarakteriseerd als ecosysteem-ingenieurs (zie bijvoorbeeld Ramirez et al., 2019). Daarmee wordt rekenschap gegeven van het feit dat deze dieren een sleutelrol spelen in de wijze waarop het ecosysteem vorm krijgt en zich ontwikkelt, met de daaraan gekoppelde biodiversiteit. Hierbij wordt veel aandacht besteed aan de verstoringen die zij veroorzaken in het ecosysteem waarmee openheid wordt gecreëerd in (bos)vegetaties en waardoor soorten die profiteren van die openheid zich kunnen handhaven. Vooral in open habitats als graslanden is dit van groot belang voor het handhaven van de soortenrijkdom (zie bijvoorbeeld Schütz, 2005). Naast de effecten van begrazing is hierbij ook bodemverstoring van belang (door wroeten van wild zwijn, maar ook bijvoorbeeld via stierenkuilen). Verder spelen hoefdieren een rol in de verbreiding van zaden, en hun mest en kadavers vormen een substraat voor een veelheid aan daaraan gerelateerde organismen. In analogie met de slogan "Dood hout leeft" kan hetzelfde gezegd worden van dode hoefdieren. Ten slotte zorgen wilde hoefdieren, voor zover zij dagelijks en met de jaargetijden kunnen migreren, voor transport en distributie van voedingsstoffen van rijke naar arme gebieden (Malhi et al., 2016). Wilde hoefdieren gaan al miljoenen jaren een interactie aan met de vegetatie en fauna van ecosystemen en de huidige biodiversiteit is daarmee gebaat bij hun aanwezigheid.

Vanuit hun rol als ecosysteem-ingenieurs hebben hoefdieren ook sterkere effecten op het ecosysteem naarmate hun dichtheden toenemen. Deze effecten kunnen als ongewenst of zelfs schadelijk worden ervaren door beheerders wanneer deze afbreuk doen aan een gesteld terreindoel. In dat geval is er sprake van een te hoge stand, waarmee de maatschappelijke draagkracht wordt overschreden. In de wetenschappelijke literatuur wordt voor deze situatie gesproken van 'overabundance' (Côté et al., 2004), wat vertaald zou kunnen worden in 'overtalligheid' en wordt gedefinieerd als een situatie waarbij hoefdieren "het voorkomen of de grootte van populaties of natuurlijke hulpbronnen beperken of wanneer zij een waardevol ecosysteem proces of menselijke activiteit negatief beïnvloeden. Voorbeelden zijn onder andere het verlies aan biodiversiteit, schade aan landbouw- of bosbouwgewassen, verlies van landschappelijke beplantingen, verkeersongelukken en verandering in de habitat van andere soorten (Healy et al. 1997)". De waardering van de effecten van hoefdieren op het functioneren van ecosystemen, en dus ook de boshabitattypen Oude eikenbossen en Beukeneikenbossen met hulst, kan daarmee niet los worden gezien van de doelen die gesteld worden voor de ontwikkeling van de structuur en samenstelling van deze systemen.

De doelen die gesteld worden voor de terreinen op de Veluwe zijn even divers als de vele terreineigenaren. Toch is een aantal gemeenschappelijke doelen te onderscheiden, zoals de wens tot het verhogen van het aandeel loofbomen en het ontwikkelen van een gemengd en compleet bos (Staatsbosbeheer 2015; Vereniging Natuurmonumenten 2006; Geldersch Landschap \& Kasteelen, ongedat.). De motieven daarvoor kunnen wel verschillen, zoals meer diversiteit in de boomlaag en de daaraan gekoppelde overige flora en fauna, omvorming naar inheems bos, risicospreiding, aanpassing aan klimaatverandering of het tegengaan bodemverzuring. 
Voor de boshabitattypen Oude eikenbos en Beuken-eikenbossen met hulst, of meer in het algemeen de bossen die zijn aangewezen als natuurbos, zijn de doelen in veel gevallen minder duidelijk geformuleerd. Vaak wordt ingestoken op het primaat van 'natuurlijke processen', waarbij de mens duidelijk een stap terugzet en het ecosysteem zich volledig spontaan kan ontwikkelen. Hierdoor wordt de natuurlijke successie leidend en worden de daaruit voortvloeiende patronen in structuur en samenstelling van de ecosystemen geaccepteerd, ongeacht de uitkomst. De doelen zijn daarmee het zo veel mogelijk aanwezig zijn van sturende processen en niet zozeer de patronen die daaruit ontstaan.

In de praktijk blijkt dit echter op de langere termijn lang niet altijd houdbaar. Het optreden van natuurlijke processen wordt in een aantal gevallen actief beteugeld, zoals het optreden van bosbranden, het uitbreken van insectenplagen of het uitbreken van ziektes in hoefdierpopulaties. Verder kan natuurlijke successie leiden tot het ontstaan van patronen in landschap of vegetatie die bij nader inzien als onwenselijk worden gezien. Op veel plekken zijn uitheemse boomsoorten aangeplant die nu ook in de successie binnen inheems bos een rol gaan spelen. Verder groeit bij het uitblijven van beheeringrepen in het bos het kronendak dicht en verdonkert het bos bij uitblijven van verstoringen. Vanwege de gemiddeld jonge leeftijd en perceelsgewijze opbouw van het bos raakt de bosontwikkeling voor lange tijd 'op slot', wat leidt tot het uitblijven van de gewenste structuurvariatie in bossen, vooral in bossen met schaduw verdragende soorten als de beuk. Dat noopt terreinbeheerders om in veel gevallen toch in te grijpen in de bosontwikkeling, met name waar het bossen betreft met een sterke cultuurinvloed (zie bijvoorbeeld Vereniging Natuurmonumenten, 2006, 2014; Staatsbosbeheer, 2015).

Wilde hoefdieren zijn iconen voor een meer 'natuurlijk' landschap en door hun rol als ecosysteemingenieur worden vrij levende populaties grote herbivoren gezien als symbool van wilde natuur. Zij belichamen de gewenste natuurlijke processen en van veel kanten gaan stemmen op om populatiebeheer door de mens achterwege te laten. Hierbij wordt voorbijgegaan aan het feit dat populaties wilde hoefdieren al vele tienduizenden jaren door de mens worden bejaagd. Bovendien blijkt het volledig vrij laten van populatiebeheer ook een keerzijde te hebben: door de sterke toename van de wilddruk verandert het landschap en komen populaties van andere dier- en plantensoorten onder druk te staan. De Oostvaardersplassen en de Amsterdamse Waterleidingduinen zijn daarvan sprekende voorbeelden: de sterke groei van populaties hoefdieren heeft daar geleid tot dermate grote veranderingen ten koste van vele soorten insecten en vogels, waarna uiteindelijk toch is gekozen tot het actief reduceren van de wildstanden om andere natuurwaarden te kunnen behouden. Met andere woorden: de aanname dat het met 'de natuur' wel goed komt bij het volgen van louter spontane processen, wordt uiteindelijk ingehaald door de constatering dat dit ten koste gaat van andere, aanvankelijk impliciete doelen die uiteindelijk expliciet gemaakt worden. Er is dan, in het geval van wilde hoefdieren, sprake van een situatie van overabundance en wordt er alsnog ingegrepen om verdere achteruitgang van gewenste soorten te voorkomen.

Ruimte en tijd spelen in dit kader een belangrijke rol. De boslandschappen en -vegetaties waarin de populaties hoefdieren toenemen, kenden voorheen een veel minder grote wilddruk en moeten zich bij een toename van hoefdierpopulaties dus nog aanpassen aan de nieuwe situatie. Daarbij ontwikkelt het landschap, met de daarin aanwezige biodiversiteit, zich in een niet vooraf gekende richting.

Aanvankelijk groeien populaties hoefdieren gestaag, maar mettertijd wordt een dynamisch evenwicht bereikt en gaan populatiedichtheden fluctueren (zie Cornelissen, 2017 en paragraaf 4.1). Hierbij valt te verwachten dat er periodes komen waarin door ziektes of andere verstoringen tijdelijk veel lagere wildstanden aanwezig zullen zijn, waardoor op de langere termijn toch vestigingsmogelijkheden overblijven voor tijdelijk verdwenen of sterk gereduceerde populaties planten en dieren. Tevens zijn de Nederlandse voorbeelden van vrij levende populaties ruimtelijk sterk ingeperkt, waardoor effecten altijd op dezelfde plek geconcentreerd blijven. Wanneer hoefdierpopulaties zich over grote oppervlakten kunnen verspreiden, met een breed scala aan habitats, in een compleet ecosysteem met predatoren en effecten over een lange tijdperiode kunnen doorwerken, zal dit weer andere gevolgen hebben voor het voorkomen van overige biodiversiteit dan nu het geval is op de korte termijn in relatief kleine, geïsoleerde gebieden. 
Wat betekent dit nu voor de boshabitattypen Oude eikenbossen en Beuken-eikenbossen met hulst? In voorgaande paragrafen is reeds geconstateerd dat veel van de huidige Oude eikenbossen zijn ontstaan in een sterk begraasd landschap en dat hun huidige verschijningsvorm een duidelijke begrazingscomponent kent. Dit was echter begrazing door vee (met name schapen, maar ook runderen) en uiteindelijk moesten veel van deze bossen weer beschermd worden tegen de invloed van het vee ('in vrede gelegd') om degradatie te voorkomen. Het open karakter van deze bossen is het gevolg van historisch beheer en verdere ontwikkeling zal afhangen van de mate waarin onder meer begrazing door hoefdieren een rol blijft spelen. De kwaliteitssoorten in dit habitattype zijn afhankelijk van openheid en begrazing kan als proces die openheid bewaren. Een hoge graasdruk zou echter ook kunnen leiden tot het verminderen van populaties kwaliteitssoorten, wat als ongewenst kan worden gezien. Daarnaast kan een hoge wilddruk de verjonging van boomsoorten zodanig belemmeren dat uiteindelijk alleen een verouderende boomlaag overblijft zonder nieuwe aanwas. Dit zal uiteindelijk kunnen leiden tot degradatie van het bos en bij uitblijven van verjonging van eik, zelfs tot het niet meer kwalificeren als habitattype.

Begrazing door hoefdieren speelt van oudsher een veel minder grote rol in de Beuken-eikenbossen met hulst op de Veluwe. Sterker nog: wat we weten over de historie van deze bossen is overgeleverd via de malenboeken, waarin de boetes werden geregistreerd die werden opgelegd bij overtreding van het verbod vee te weiden in het bos (Hacke Oudemans, 1969; Horst, 2011). De Beuken-eikenbossen met hulst vormen een bosecosysteem in een later successiestadium, maar zijn door het historisch beheer sterk verarmd geraakt aan boomsoorten. Natuurlijke dynamiek in deze bossen zou kunnen leiden tot vestiging van een meer diverse boomsoortensamenstelling. Dit is bij een hoge wildstand echter niet het geval, zoals onder andere in het Faunabeheerplan Grote Hoefdieren 2019-2025 (FBE Gelderland 2019) is geconstateerd en in navolgende hoofdstukken verder zal worden toegelicht. Hoewel vanuit de profielendocumenten geen expliciete aandacht wordt besteed aan de boomsoorten in dit habitattype, wordt vanuit de provinciale insteek (Bijlage 1) wel expliciet de wens geuit dat loofboomsoorten zich in dit boshabitattype onbelemmerd kunnen verjongen. Indirect geldt tevens als kwaliteitskenmerk dat geen exoten in dit bostype aanwezig zijn.

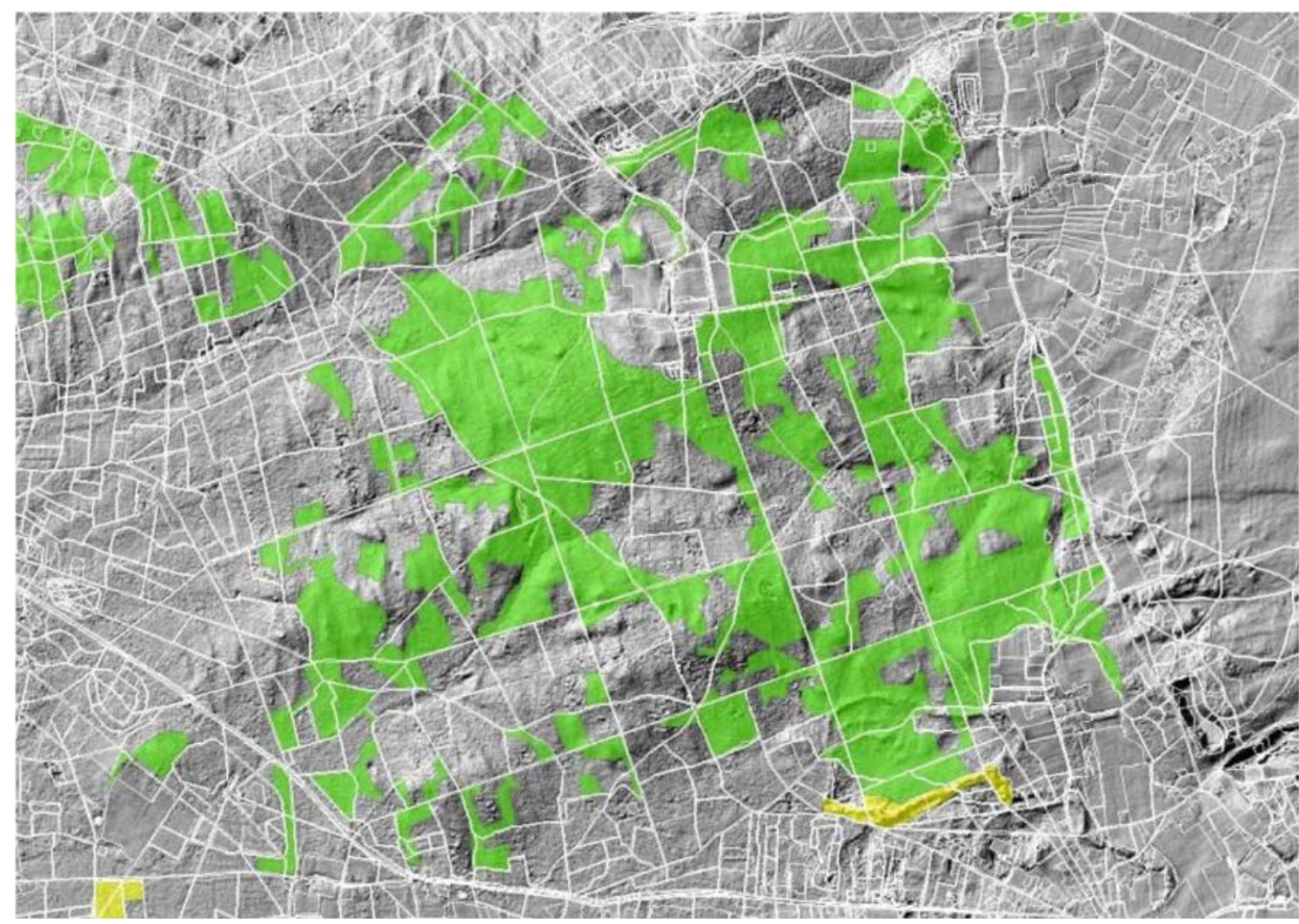

Figuur 6 Kwalificerend habitat Beuken-eikenbossen met hulst (groen) en Oude eikenbossen (geel) in het Speulder- en Sprielderbos. De habitattypen zijn sterk versnipperd. De grootte van de kaart komt ongeveer overeen met het leefgebied van een edelhert. Achtergrond van de kaart op basis van het Actueel Hoogtebestand Nederland. Kaart van Rienk-Jan Bijlsma. 
Dit rapport richt zich op de Natura 2000-boshabitattypen, maar wanneer we naar de relatie met hoefdierpopulaties kijken, mag het omringende, niet voor Natura 2000 kwalificerende bos niet buiten beeld blijven. De schaal waarop de aangewezen boshabitattypen op de Veluwe voorkomen, is bijna altijd kleiner dan de schaal waarop hoefdieren gebruikmaken van het landschap en bovendien liggen de boshabitats verweven met niet-kwalificerende bossen (Figuur 6). Hoefdieren maken dus altijd gebruik van zowel kwalificerende als niet-kwalificerende habitats. Deze laatstgenoemde zijn bovendien van belang voor het functioneren van de boshabitattypen; soorten die van belang zijn voor de boshabitattypen komen evengoed voor in de omringende bossen. Bovendien moet eventuele uitbreiding van kwalificerende habitats plaatsvinden via omvorming van bestaand bos. De gewenste of ongewenste ontwikkeling in bossen als gevolg van effecten van hoefdieren gelden in principe ook voor niet-kwalificerende boshabitats.

Voor de uiteindelijke evaluatie van de interactie tussen hoefdieren en Natura 2000-boshabitats kunnen uit het voorgaande de volgende concrete doelen worden geformuleerd:

- Alle bij de groeiplaats behorende inheemse loofboomsoorten moeten zich in voldoende mate kunnen verjongen, zodat populaties van deze soorten duurzaam aanwezig kunnen blijven.

- Toekomstige bosgeneraties hebben een diverse boomsoortensamenstelling.

- Benoemde (bijzondere) kwaliteitssoorten en typische soorten blijven aanwezig in levensvatbare populaties.

- Exoten spelen geen rol van betekenis.

- Wilde hoefdieren komen voor in levensvatbare populaties.

In de hiernavolgende hoofdstukken zal worden geëvalueerd hoe, en in welke mate, variatie in wilddruk leidt tot de mogelijkheden deze doelen te realiseren op de Veluwe. 


\section{Effecten van hoefdieren op vegetatie}

Grote herbivoren hebben directe en indirecte effecten op de vegetatie. Vice versa bepaalt de vegetatie, met name via de beschikbaarheid van voedselbronnen en mate van beschutting, het voorkomen van grote herbivoren. Het gebruik van de habitat en van verschillende voedselbronnen, zoals kruiden, grassen en de knoppen en bladeren van houtige planten, varieert per diersoort (3.1). Binnen het dieet hebben soorten ook weer een voorkeur voor bepaalde plantensoorten (3.2), waardoor de soortensamenstelling van de vegetatie door begrazing verandert. De vraat van grote herbivoren vormt een belangrijke verstoring voor planten, omdat hiermee bladeren, bloemen en knoppen verdwijnen (3.3). Jonge bomen kunnen ook afsterven na intensief schillen of vegen van de bast. Wroetende wilde zwijnen verstoren de humuslaag en bovenste delen van de minerale bodem waarmee ook aanwezige planten kunnen verdwijnen.

Door de aanwezigheid van grote herbivoren verandert de structuur van de habitat of de snelheid waarmee die structuur verandert. Een hoge vraatdruk op houtigen voorkomt de vestiging van een struiklaag, waardoor de lichtbeschikbaarheid voor de ondergroei hoger is en zich een soortenrijkere bodemvegetatie kan handhaven (Nessing \& Zerbe, 2002). Waar de wilddruk minder hoog is, leidt dit tot vertraging van de hoogtegroei van veel soorten, maar zal zich uiteindelijk ook een nieuwe struiklaag vormen. Daarnaast worden veel plantensoorten verbreid via de mest, hoeven of vacht (Schmidt et al., 2004; Von Oheimb et al., 2005). Verstoring door hoefdieren kan uiteindelijk ook een gunstig effect hebben op bepaalde soorten die juist profiteren van de situatie die ontstaat na verstoring. Zo profiteert de aardbeivlinder (Pyrgus malvae) van het gewroet van wild zwijn doordat dit leidt tot een betere voedselkwaliteit van de waardplant tormentil (Potentilla erecta) (De Schaetzen et al., 2018).

\subsection{Voedselkeuze en terreingebruik}

Onder de herbivoren zijn wat betreft voedselkeuze verschillende typen te onderscheiden (Hofmann 1989). Allereerst is er het onderscheid tussen herkauwers en niet-herkauwers. De herkauwers kunnen verder worden onderverdeeld naar het geprefereerde type voedsel dat zij tot zich nemen.

Onder de herkauwers worden de volgende drie groepen onderscheiden (zie Figuur 7):

- Grazers: deze dieren kunnen naar verhouding meer voedsel opnemen en dit langer onderwerpen aan de invloed van microben, waardoor ze cellulose relatief goed verteren. Bij uitstek aangepast aan het eten van grassen en grasachtigen. Runderen, wisenten en schapen behoren tot deze groep.

- Browsers: deze dieren houden het voedsel relatief kort vast en kunnen daardoor maar beperkt vezelrijk materiaal verteren. Ree en eland behoren tot deze groep.

- Intermediate feeders: deze dieren houden het midden tussen bovenstaande groepen, zijn dus flexibel en in staat zich aan te passen aan een celluloserijk en -arm dieet. Het edelhert en damhert behoren tot deze groep.

Het omnivore wild zwijn en ook de paardachtigen behoren tot de groep van niet-herkauwers. Door de doorstroomsnelheid door het maag-darmkanaal te verhogen, zijn paarden in staat om slechter verteerbare grassen op te nemen in hun dieet dan runderen. De herbivoren met meerdere magen kunnen echter beter omgaan met houtige gewassen, zoals vlier (antivraatstoffen). Deze verschillen maken dat paarden, runderen en herten net even ander voedsel prefereren, maar elkaar wel kunnen beïnvloeden. 


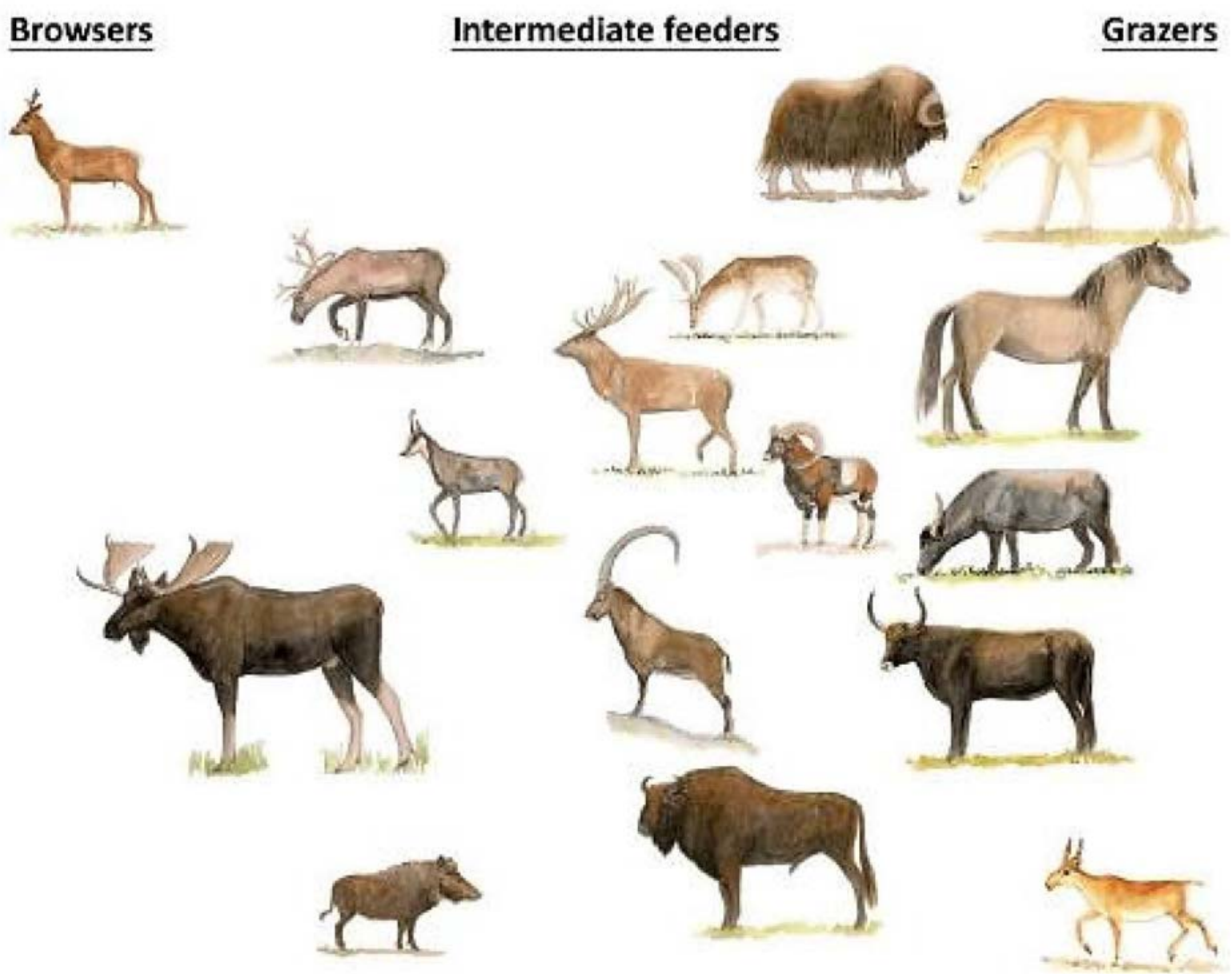

Figuur 7 De rangschikking van Europese hoefdieren over de verschillende voedselstrategieën. Figuur uit www.freenature.nl.

\subsubsection{Edelhert}

Groot Bruinderink \& Hazebroek (1995) deden onderzoek naar de dieetkeus van edelherten op de Veluwe op basis van de pensinhoud. Zij vonden geen verschil in dieetkeus tussen geslacht en leeftijd, maar onderzoek in Denemarken (Fløjgaard et al., 2017) liet zien dat dominante geweidragers bezit namen van de betere voedselplekken met hoogwaardiger voedsel. Op de Veluwe bestond het dieet van edelherten vooral uit bochtige smele, blauwe bosbes, eikels en bladeren, twijgen en knoppen van loofbomen (Figuur 8). Loofbomen worden vooral gegeten gedurende het groeiseizoen en maakt op jaarbasis 12 vol\% van het dieet uit (Groot Bruinderink et al., 1998). Bochtige smele (19 vol\%) en breedbladige grassen ( 8 vol\%) worden op jaarbasis ook veel gegeten. Daarnaast was mast van eik (12 vol\%) op jaarbasis een belangrijk voedselitem. Naast eikels en beukennootjes hebben edelherten een voorkeur voor de zaailingen en jonge boompjes van loofboomsoorten als wilde lijsterbes, eik en beuk. Ook op basis van fecesanalyse werd duidelijk dat loofbomen, en met name eik, in het groeiseizoen de belangrijkste component van het dieet vormen (Groot Bruinderink et al., 1997b).

Edelherten hebben qua terreingebruik een voorkeur voor grasland, beukenbos, eikenbos en kapvlaktes, zijn indifferent naar grove dennenbos en mijden heide en overig naaldbos (Groot Bruinderink et al., 1998). Het terreingebruik varieert over het jaar, afhankelijk van het voedselaanbod (Kuiters et al., 2005). In het najaar en winter wordt grasland frequent benut. Gedurende het groeiseizoen is grasland minder in trek en foerageren herten meer in bossen waar beter verteerbaar, hoogwaardig voedsel te vinden is.

De meest voorkomende sociale eenheid bij edelherten bestaat uit een hinde met haar smaldier/spitser en kalf, waarbij meerdere van dit soort eenheden gezamenlijk optrekken. Tijdens de bronst vormen ze groepen met een adult mannelijk dier (Clutton-Brock et al., 1982). Buiten de bronstperiode komen 
grote groepen met hinden, smaldieren/spitsers en kalveren voor, met daarnaast en ruimtelijk gescheiden daarvan groepen mannelijke dieren. De gemiddelde groepsgrootte ligt op jaarbasis meestal rond de 3-5 dieren, maar grotere groepen met tientallen dieren kunnen voorkomen (Groot Bruinderink \& Lammertsma, 2001). De gemiddelde groepsgrootte is afhankelijk van vele factoren, zoals dichtheden, voedselaanbod en jacht. Huysentruyt \& Casaer (2015) constateren in het experiment Deelerwoud dat de dichtheden toenamen en dat de gemiddelde groepsgrootte steeg van ca. 2 naar ca. 6 dieren, hetgeen gezien wordt als een normaal patroon (Jedrzejewski et al., 2006). In Polen werd echter geconstateerd dat intensieve jacht tot dalende dichtheden leidde, terwijl de groepsgrootte toenam van 3-4 naar ca. 6-8 dieren, mede als gevolg van interacties met predatoren (Jedrzejewski et al., 2006).

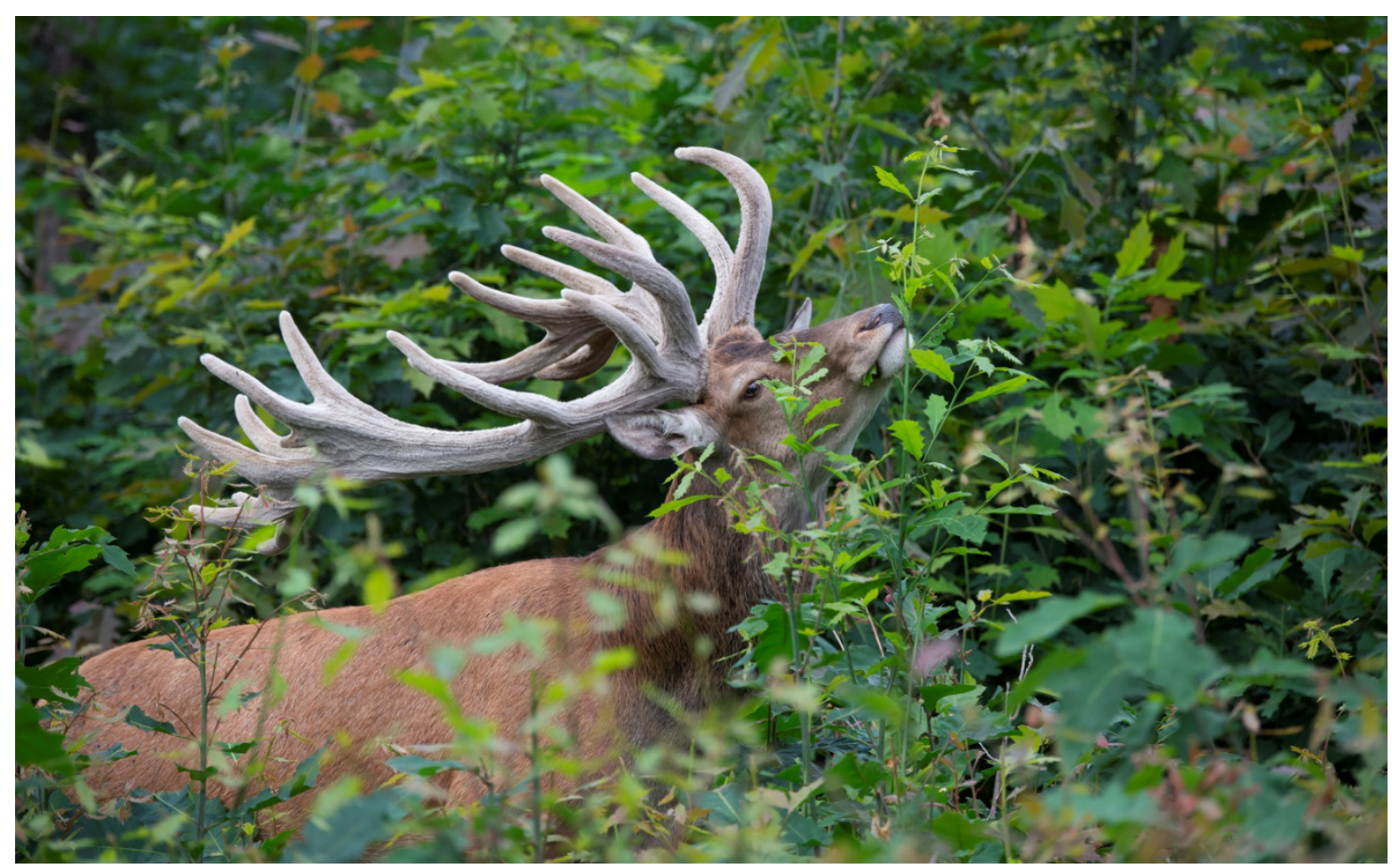

Figur $8 \quad$ Edelhert foeragerend op Amerikaanse eik.

\subsubsection{Wild zwijn}

Het dieet van het wild zwijn op de Veluwe varieert en is sterk afhankelijk van het (lokale) voedselaanbod en het optreden van mastjaren van eik en beuk (Groot Bruinderink \& Hazebroek, 1994; Groot Bruinderink et al., 1998). In een mastarm jaar bestaat het dieet op jaarbasis vooral uit breedbladige grassen (46 vol\%), aangevuld met eikels (16 vol\%), beukennootjes (17 vol\%) en wortelstokken van adelaarsvaren (11 vol\%). In een mastrijk jaar bestaat het dieet op jaarbasis vooral uit mast van eik (16 vol\%) en beuk (38 vol\%), aangevuld met breedbladige grassen (32 vol\%). Daarnaast wordt zowel in mastrijke als -arme jaren dierlijk voedsel gegeten ( 2 vol\%). Vooral in het najaar en de winter wordt in mastrijke jaren veel mast van eik en beuk gegeten (70-82\% van het dieet), terwijl gedurende het groeiseizoen vooral breedbladige grassen worden benut (Groot Bruinderink \& Hazebroek, 1994).

Wildzwijnen hebben qua terreingebruik een voorkeur voor grasland, beukenbos, eikenbos en kapvlaktes en mijden heide, grove dennenbos en overig naaldbos (Groot Bruinderink et al., 1998). Zodra er mast beschikbaar komt, kan dit in de praktijk betekenen dat grote groepen gedurende een maand of langer in een en hetzelfde beuken- of eikenvak foerageren.

Aggregaties en terreingebruik van wilde zwijnen zijn zeer dynamisch en afhankelijk van veel factoren zoals het voedselaanbod, de dichtheid aan wilde zwijnen, verstoring door jacht en de reproductiecyclus. Zeugen leven door de bank genomen in wisselende familieverbanden in rottes, terwijl keilers solitair leven (Keuling et al., 2008; Groot Bruinderink et al., 2009). 


\subsubsection{Ree}

Het dieet van het ree op de Veluwe bestaat op jaarbasis vooral uit blad, stengels en knoppen van loofbomen (35 vol\%) en blauwe bosbes (36 vol\%) aangevuld met mast van eik en beuk (resp.

3 en 6 vol\%) (Groot Bruinderink et al., 1998). Gedurende het groeiseizoen vormen loofbomen, tot ca. maximaal $90 \%$, de belangrijkste voedselbron waarbij, op basis van fecesanalyse, vooral eik wordt gegeten (Groot Bruinderink et al., 1997b). Reeën foerageren hierbij selectief op onderdelen van planten die goed verteerbaar zijn met een dunne celwand, een laag ligninegehalte en weinig antivraatstoffen.

Reeën hebben qua terreingebruik een voorkeur voor beukenbos, eikenbos, kapvlaktes en (kruidenrijk) grasland en mijden heide, grove dennen- en overig naaldbos (Groot Bruinderink et al., 1998).

Reeën vormen in de winter vaak grote groepen. Vanaf het voorjaar vallen deze groepen uit elkaar en bestaat de sociale eenheid uit een geit met haar kalf of kalveren. Bokken blijven dan tot de bronst solitair. De gemiddelde groepsgrootte op jaarbasis is ca. 1,5 voor geiten met hun nageslacht en 1 voor de bokken (Groot Bruinderink \& Lammertsma, 2001; Huysentruyt \& Casaer, 2015).

\subsubsection{Damhert}

Over het specifieke dieet van damherten op de Veluwe is niets bekend. Het dieet van damherten lijkt veel op het edelhert, maar damherten eten over het algemeen iets meer grassen (Groot Bruinderink et al., 1998). In het duingebied van de Manteling van Walcheren eten damherten jaarrond veel grassen en zegges (36\%), aangevuld met dicotylen waarvan Amerikaanse vogelkers, meidoorn en esdoorn de belangrijkste houtigen in het dieet waren (De Jong, 2000). In het duingebied van de Manteling van Walcheren hebben damherten een voorkeur voor struweel, naaldbos en loofbos en mijden open vegetatietypen, zoals grasland en cultuurgrond.

Damherten hebben een met edelherten vergelijkbaar sociaal systeem waarbij buiten de bronst grotere groepen met vrouwtjes, smaldieren/spitsers en kalveren voorkomen, met daarnaast en gescheiden daarvan groepen mannelijk dieren. De gemiddelde groepsgrootte op jaarbasis ligt op ca. 3-5 dieren, waarbij de groepsgrootte stijgt met de dichtheid (Huysentruyt \& Casaer, 2015).

\subsubsection{Overige hoefdiersoorten}

Voor paarden geldt dat ze, op basis van fecesanalyse, het gehele jaar door vooral grassen eten op de Veluwe (Groot Bruinderink et al., 1997b). Houtigen zoals Amerikaanse eik, wilg, sporkehout worden beperkt gegeten in het groeiseizoen, maar kunnen vanaf september tot april onderdeel uitmaken van het dieet. Meestal betreft het enkele procenten, maar het aandeel kan in sommige maanden oplopen tot ca. $40 \%$. Bochtige smele wordt vooral gegeten in loofbos en in mindere mate in naaldbos.

Ook runderen op de Veluwe komen jaarrond voor op grasland en eten voornamelijk grassen (Groot Bruinderink et al., 1997b; Kuiters et al., 2005). In het groeiseizoen maakt gras ca. $60 \%$ van het dieet uit, in de winter ca. $40 \%$. Sporkehout vormt op basis van fecesanalyse 's winters een belangrijk aandeel van het dieet, wilde lijsterbes wordt vooral gegeten in het voorjaar tot de vroege zomer en eik wordt in de zomermaanden gegeten. Bochtige smele wordt zowel in loof- als naaldbos gegeten.

Over het dieet van wisenten op de Veluwe is weinig bekend. Jaarrond wordt veel gegraasd en vindt vraat plaats van blad, twijgen en bast van Amerikaanse vogelkers, bast van eik en worden eikels gegeten (Wisent op de Veluwe, 2017). Op jaarbasis bestaat ca. 80-90\% van het dieet uit grassen en 10-20\% uit houtigen (voornamelijk bast) (Gebzynska et al., 1991; Borowski \& Kossak, 1972; ValdésCorrecher et al., 2018). Vooral in de wintermaanden zou er veel geschild worden. Alle studies over de dieetkeus van wisenten zijn echter van populaties die met hooi worden bijgevoerd in de winter. In Polen hebben ze in bosgebieden een voorkeur voor open (bos)biotopen (Kowalczyk et al., 1976). Wisenten, zowel in Bialowieza als in Borecka Forest, foerageren voor 30-40\% in open gebied (weide, kapvlakte, aanplant tot 10 jaar oud en cultuurgrond) en voor 60-70\% in loofbos en gemengd bos (Krasinska et al., 1987; Krasinska \& Krasinski, 1995; Krasinski \& Krasinska, 1992). Opstanden die ouder zijn dan 20 jaar worden geprefereerd, dichte opstanden die tussen de 10-20 jaar oud zijn, worden slechts zelden bezocht. Naaldbos en vochtig loofbos wordt gemeden. Droge loofbossen worden sterk geprefereerd (43\% van de waarnemingen, terwijl het aanbod slechts $16 \%$ bedroeg). 
Over het specifieke dieet van moeflons op de Veluwe is niets bekend. Het dieet van moeflons kan sterk variëren, afhankelijk van het klimaat en voedselaanbod (Maisels, 1988; Marchand et al., 2013; Obidzińskia et al., 2017). Moeflons in Polen en Tsjechië eten vooral grassen gedurende het groeiseizoen (40-65 vol\%), maar 's winters daalt het aandeel naar ca. 20\% (Heroldova, 1996; Obidzińskia et al., 2017). Houtigen maken buiten het groeiseizoen onderdeel van het dieet uit in Tsjechië en Polen (46-56 vol\%). Daarnaast eten ze in mastrijke jaren mast van eik en beuk (Obidzińskia et al., 2017). Gedurende het groeiseizoen spenderen moeflons ongeveer even veel tijd in open habitat als in bos, gedurende de winter wordt meer gebruikgemaakt van open biotopen (Obidzińskia et al., 2017). Moeflon lijkt op de Veluwe een van de belangrijkste grazers op grove den (J. den Ouden, pers. obs.), al kan dit de kolonisatie van heidevelden door grove den niet tegenhouden.

\subsubsection{Effecten op basis van dieetkeus en terreingebruik}

Gezien het gedrag, de habitatvoorkeur en de dieetkeus van hoefdieren op de Veluwe kan van alle soorten een effect worden verwacht op de habitattypen Oude eikenbossen en Beuken-eikenbossen met hulst. Hoewel gegevens beschikbaar zijn over de dieetkeus en habitatvoorkeur van de hoefdiersoorten, is echter niet bekend waar ze wat eten op welk moment. Gedetailleerde informatie over het terreingebruik op de Veluwe is niet voorhanden, met uitzondering van enkele kleinschalige studies met gezenderde edelherten (zie bijvoorbeeld Van den Broek, 2015; Van Woersem \& Elders, 2016) en natuurlijk de schat aan anekdotische informatie van terreinbeheerders en jachtopzieners over het voorkomen van hoefdieren op hun terreinen. Gezien het grote belang van eikels en beukennoten in het dieet van hoefdieren (zie hierboven), vormen de twee boshabitattypen een belangrijk foerageergebied voor hoefdieren, zeker in de herfst en vroege winter.

Globale voorkeuren voor habitats zijn in de voorgaande paragrafen aangegeven, en aangenomen kan worden dat het dieet hoofdzakelijk gerealiseerd wordt in de preferente habitats. Maar het terreingebruik wordt niet alleen gestuurd via voedselbeschikbaarheid; ook veiligheid en microklimaat spelen een belangrijke rol in het terreingebruik van dieren (zie onder andere Reimoser, 2003). Daarnaast is het activiteitenpatroon van belang. Wilde hoefdieren hebben, afhankelijk van de periode van het jaar, gedurende de dag cycli van activiteit en rust. In de context van de Veluwe speelt daarbij verstoring door recreatie een belangrijke rol en is het activiteitenpatroon van hoefdieren sterk geconcentreerd tussen avond- en ochtendschemer (Worm \& van Wieren, 1996). Veelal worden vaste rustplaatsen (daginstanden) gebruikt die in de dekking van bos liggen (Adrados et al., 2008). De kans op vraat in en vlak bij deze daginstanden is dan ook aanzienlijk hoger dan in verder weg gelegen delen van een gebied (Figuur 9). De ligging van rust(ige) gebieden speelt dus een belangrijke rol bij het sturen van het terreingebruik. 


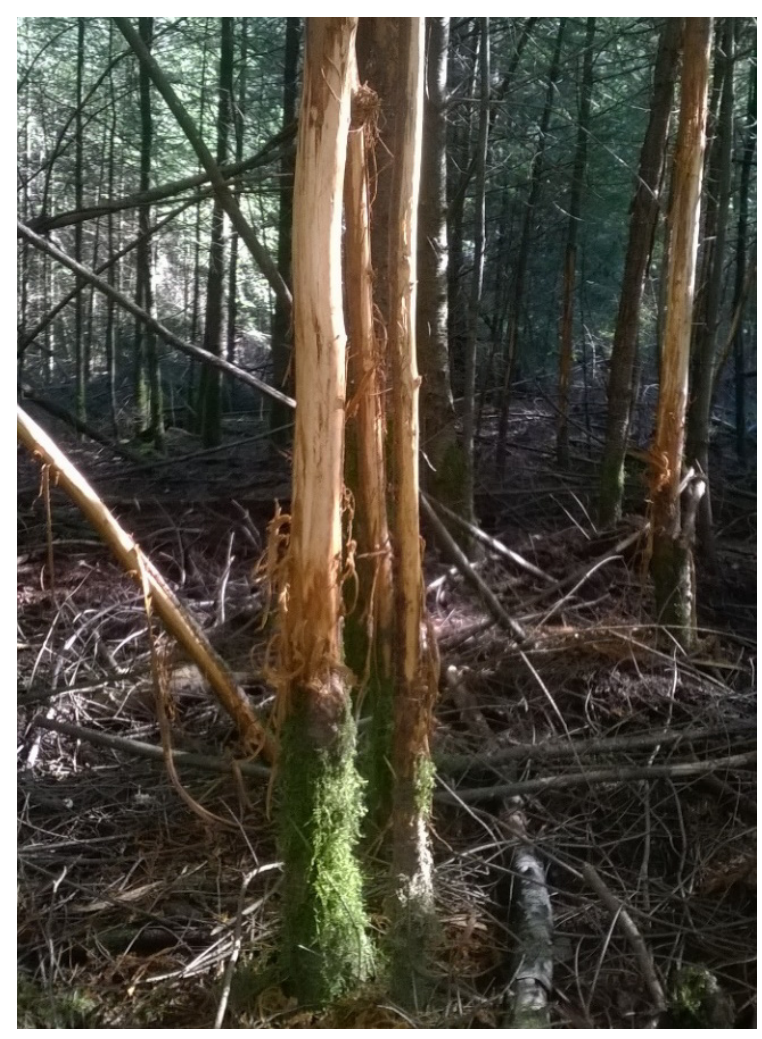

Figuur 9 Daginstand van edelhert in dichte verjonging van douglas in het Nationale Park De Hoge Veluwe, waarin een groot aandeel bomen is geschild. Dit leidt tot aanzienlijke sterfte onder de jonge bomen.

De mate waarin specifieke locaties zullen worden bezocht door hoefdieren is verder afhankelijk van de actieradius van dieren, de daarmee gerealiseerde home range en of de soort solitair of in groepsverband voorkomt. Groot Bruinderink et al. (2003) geven een globaal overzicht van de home range in respectievelijk rijke en arme habitats: ree 5-100 ha, damhert 50-750 ha, wild zwijn 100-15000 ha, edelhert 500-20000 ha.

De wilddruk op een specifieke locatie is dus sterk afhankelijk van de landschappelijke context waarin die locatie zich bevindt. Op basis van algemene informatie over de dichtheid van de populatie in een groter gebied kan niet direct een uitspraak worden gedaan over de druk op een specifieke plek. Doordat hoefdieren als gevolg van de verstorende invloed van recreanten vooral nachtactief zijn, onttrekt hun terreingebruik zich ook grotendeels aan onze directe waarneming. Getalsmatige informatie over populatiegrootte is daarmee slechts ten dele informatief voor het bepalen van wilddruk op een bepaalde locatie. Feitelijke wilddruk kan dus beter worden bepaald op basis van waar te nemen effecten op de vegetatie (zie hoofdstuk 5).

\subsection{Preferentie}

\subsubsection{Vraat aan bomen en struiken}

Jonge bomen vormen een belangrijk onderdeel van het dieet van hoefdieren (zie paragraaf 3.1), maar niet alle boomsoorten worden even vaak aangevreten. Hoefdieren hebben duidelijk een voorkeur voor bepaalde boomsoorten, onder andere afhankelijk van de verteerbaarheid voor de betreffende diersoort van de gegeten delen (Jorritsma et al., 1997) of de aanwezigheid van antivraatstoffen of fysieke afweer (zie o.a. Bokdam, 2003; Burney \& Jacobs, 2013). Ook binnen een soort kunnen verschillen in aantrekkelijkheid bestaan. Zo kunnen opgekweekte zaailingen een andere chemische inhoud hebben dan spontaan opgeslagen zaailingen, waardoor deze meer worden gegeten dan natuurlijk verjongde individuen (McArthur et al., 2003; Burney \& Jacobs, 2013). Ook kunnen gehaltes aan antivraatstoffen variëren tussen individuen van dezelfde soort. 
Diverse onderzoeken op het Nationale Park De Hoge Veluwe (Wonders, 2014; Verbeek, 2016; Kuipers, 2017; Vink, 2020), eerder onderzoek op de Veluwe (Kuiters \& Slim, 2002) en elders in Europa (o.a. Nessing \& Zerbe, 2002; Gill \& Morgan, 2010; Bobrowski et al., 2015) lieten zien dat naaldbomen duidelijk worden gemeden en dat loofbomen duidelijk geprefereerd worden door de daar aanwezige hoefdieren (edelhert, ree en moeflon). De voorkeur van hoefdieren voor bepaalde soorten varieert van jaar tot jaar, maar wilde lijsterbes scoort altijd hoog op de lijst van meest geprefereerde soorten. Daarnaast worden ook vuilboom, zachte berk en Amerikaans krentenboompje relatief veel aangevreten. Opvallend is dat de eik, een soort waarvan vaak wordt gezegd dat de verjonging sterk wordt belemmerd door hoefdieren, in veel van bovengenoemde onderzoeken niet als buitengewoon gewild naar voren komt (zie verderop in deze paragraaf).

De mate waarin een bepaalde boomsoort wordt aangevreten heeft niet alleen te maken met een 'intrinsieke' voorkeur, maar wordt ook bepaald door de context waarin de betreffende soort deel uitmaakt van de verjonging. Zo heeft de totale voedselbeschikbaarheid effect op de mate waarin bepaalde soorten worden aangevreten. In een studie op de Lüneburger Heide (D), met een hoge vraatdruk (20 ree en 0,2 edelhert per 100 ha), lieten Bobrowski et al. (2015) zien dat de vraat aan beuken toenam met de aanwezigheid van blauwe bosbes en de dichtheid aan jonge berken en beuken. Berk werd door ree duidelijk geprefereerd boven beuk en de totale vraat was afhankelijk van de lokale voedselbeschikbaarheid. Eenzelfde effect werd gevonden door Kuipers (2017) in een studie op Het Nationale Park De Hoge Veluwe, waarin werd aangetoond dat de mate van vraat aan jonge bomen positief gecorreleerd was met de aanwezigheid van andere voedselbronnen, met name blauwe bosbes en grassen. Vraat aan de verjonging nam ook toe naarmate er meer braam aanwezig was.

Ook de ruimtelijke verdeling van individuen kan bij vraat een rol spelen: in een Poolse studie naar de groei van aangeplante eiken bleek dat bij een door de auteurs als matig aangeduide wilddruk (3-4 edelhert en 3-3,5 ree per 100 ha) de jonge eiken jaarlijks sterk aangevreten werden, maar dat de uiteindelijke hoogtegroei van jonge eiken beter was wanneer de eikjes in groepjes werden geplant tussen reeds gevestigde jonge grove dennen dan wanneer de eikjes individueel tussen grove dennen werden geplant (Dobrowolska et al., 2020).

Verder kan de aanwezigheid van veel 'onsmakelijke' soorten of soorten die een fysieke belemmering vormen voor herbivoren, leiden tot een verminderde vraat aan jonge bomen (Vera, 2000; Smit, 2005). Dat betekent dat individuele bomen aan vraat kunnen ontsnappen wanneer zij in een omgeving opgroeien die op lokale schaal onaantrekkelijk is voor foeragerende dieren. Smit et al. (2007) lieten wel zien dat wanneer de graasdruk toeneemt, dit effect weer verdwijnt, omdat dan alles wordt gegeten, dus ook de minder smakelijke soorten. Dit fenomeen was ook goed te zien in de Oostvaardersplassen, waar de sterke toename van hoefdieren leidde tot het verdwijnen van de gewone vlier (Sambucus nigra) als gevolg van bast- en takvraat, terwijl dit normaal gesproken een onsmakelijke soort voor hoefdieren is (Cornelissen et al., 2014b). Dit verklaart ook de ogenschijnlijk tegenstrijdige bevindingen in relatie tot vraat aan eik: in een landschap waarin een breed palet aan soorten beschikbaar is, wordt de eik niet als preferente soort gegeten. Wanneer de smakelijke soorten door vraat sterk zijn gereduceerd, richt de vraat van hoefdieren zich wel op eik. Met andere woorden: de voorkeur voor hoefdieren voor het eten van een bepaalde soort is altijd afhankelijk van het aanbod aan overige soorten. Dit leidt ertoe dat uiteindelijk ook de minst smakelijke soorten toch worden gegeten wanneer deze als enige beschikbaar zijn (zie Figuur 10). 


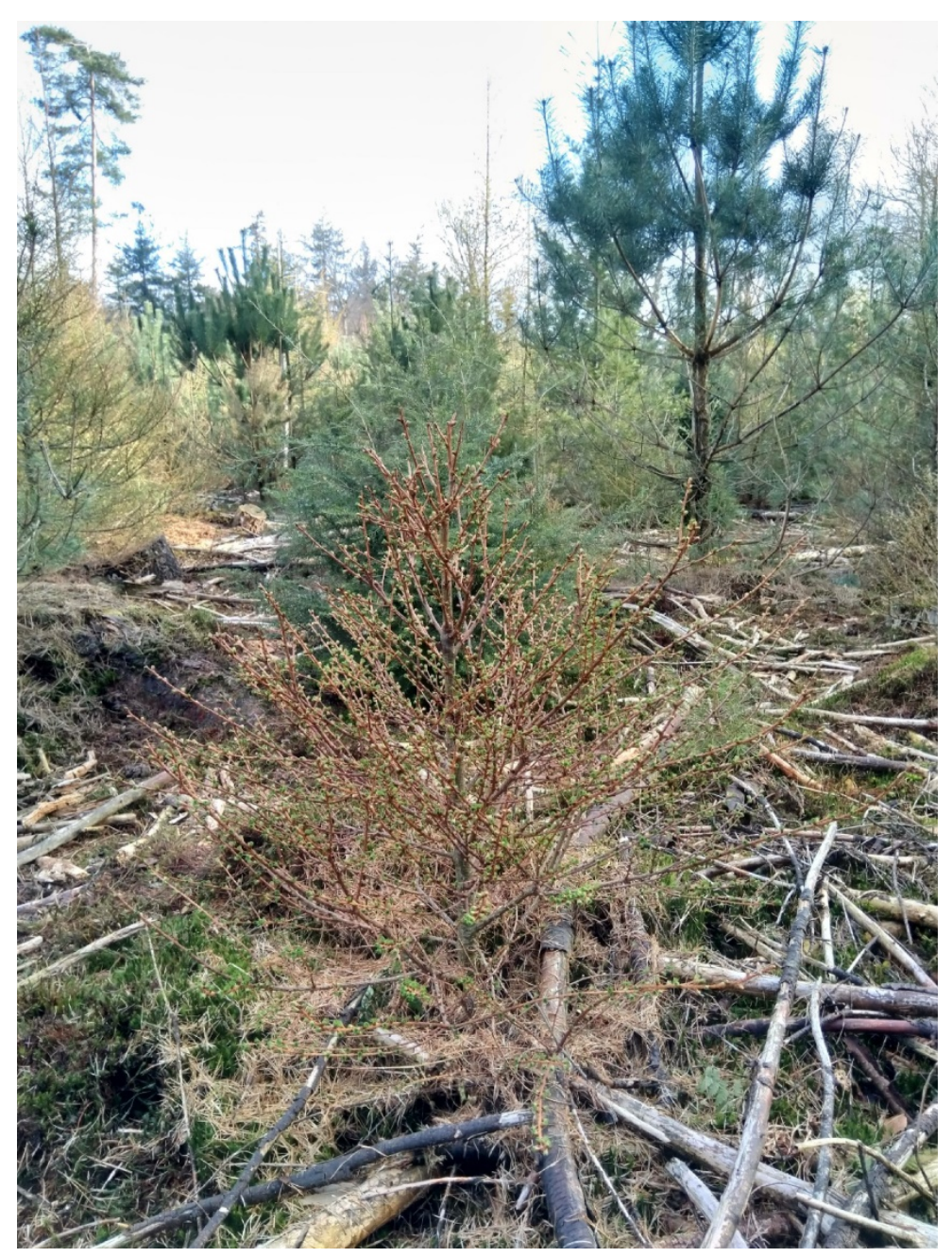

Figuur 10 Wanneer herten geen beschikking meer hebben over loofbomen worden ook soorten aangevreten die anders gemeden zouden worden, zoals deze Japanse lariks in het Speulderbos.

Bovenstaand proces speelt een belangrijke rol in relatie tot de effecten van begrazing in het voorkomen van exoten in boshabitattypen. Begrazing wordt, onder andere door Bijlsma et al. (2008), gezien als een manier om de verjonging van Amerikaanse vogelkers in Oude eikenbossen te vertragen of tegen te gaan. Deze soort scoort, evenals de Amerikaanse eik, in vergelijking met andere loofboomsoorten echter matig preferent tot neutraal. Dit betekent dat de verjonging van veel inheemse soorten als eerste wordt onderdrukt bij een toenemende graasdruk, waardoor de vestigingskansen voor Amerikaanse vogelkers worden vergroot (Nyssen et al., 2013). De dominantie van Amerikaanse vogelkers kan daardoor in veel gevallen eerder gezien worden als een gevolg van een hoge graasdruk. Eenzelfde effect zien we in de verjonging van naaldboomsoorten: door het selectief wegvreten van loofbomen wordt in Beuken-eikenbossen de verjonging in toenemende mate gedomineerd door exoten als lariks, hemlockspar en douglas, waarmee de kwaliteit van het habitattype negatief wordt beïnvloed (zie Figuur 11). 


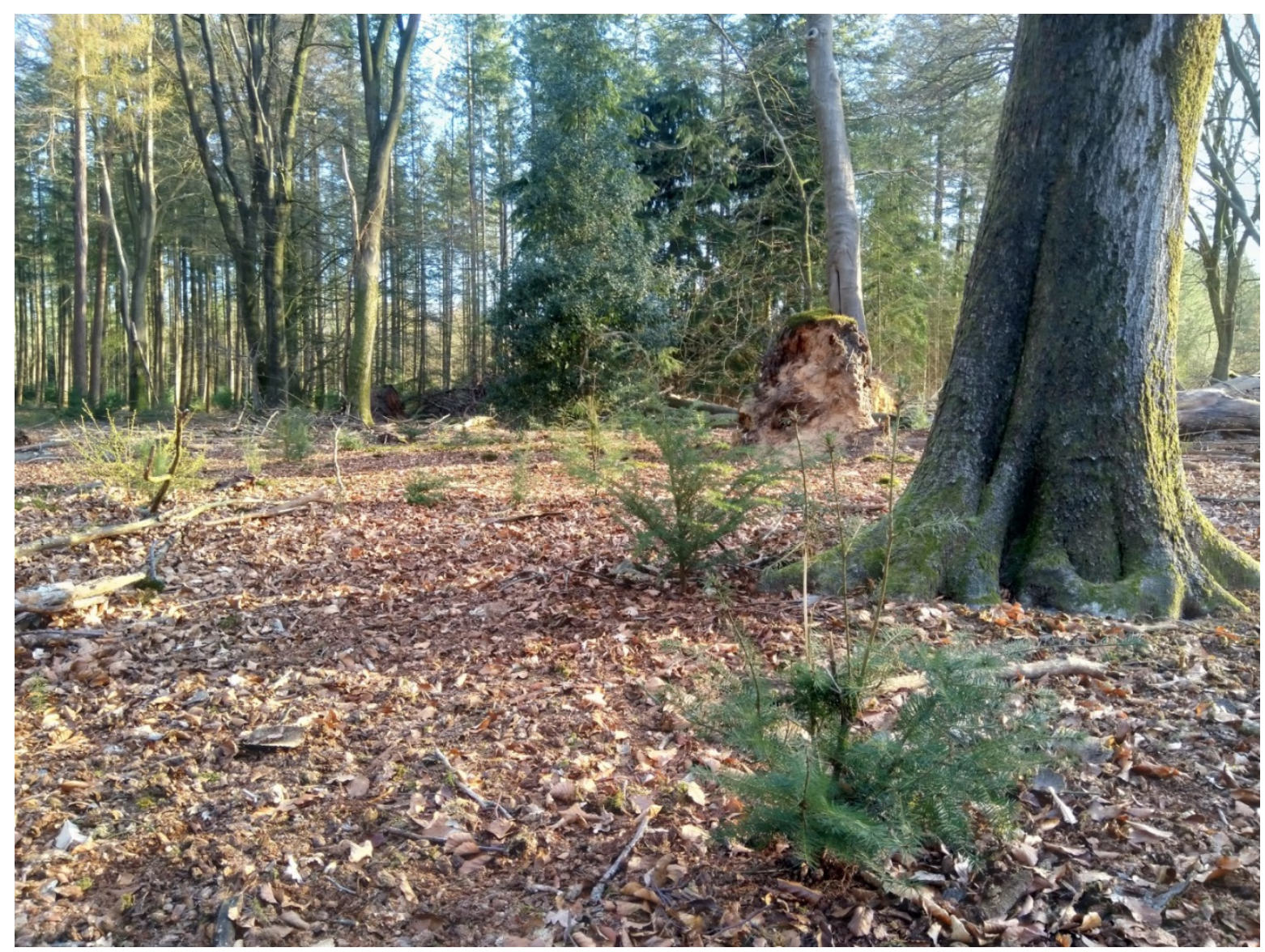

Figuur 11 Dominantie van douglas, hemlockspar en Japanse lariks in de verjonging in Beukeneikenbos met hulst (Speulderbos) als gevolg van een hoge graasdruk en de nabijheid van zaadbronnen.

Hoefdieren hebben een duidelijke voorkeur voor loofboomsoorten boven naaldbomen. Binnen de loofbomen is ook een algemene volgorde van voorkeur aanwezig, met wilde lijsterbes als een van de meest geliefde. De mate waarin jonge bomen worden aangevreten, kan variëren naargelang de dichtheid en soortensamenstelling van de directe omgeving waarin de plant staat. Naarmate de wilddruk toeneemt, vervagen de voorkeuren van hoefdieren en wordt uiteindelijk al het beschikbare voedsel, ongeacht de soort, gegeten.

\subsubsection{Vraat aan overige vegetatie}

Afhankelijk van de soortensamenstelling en dichtheid in de Veluwse deelgebieden hebben hoefdieren mogelijk ook een effect op het voorkomen van (bijzondere) kwaliteitssoorten (zie paragraaf 2.2.3 en 2.3.3). Kruiden en grassen vormen een belangrijk onderdeel van het dieet van hoefdieren, waarbij ook sprake is van een voorkeur voor, of juist vermijding van, bepaalde plantensoorten. Hiervoor geldt hetzelfde als bij bomen en struiken, en is de preferentie voor plantensoorten afhankelijk van de chemische samenstelling van planten, hun bescherming (stekels, doornen) en het relatieve voorkomen van soorten.

$\mathrm{Er}$ is erg weinig bekend over de effecten van hoefdieren op het voorkomen van specifieke plantensoorten, met name de (bijzondere) kwaliteitssoorten van de Oude eikenbossen en Beuken-eikenbossen met hulst. Valdes et al. (2019) presenteren op basis van een uitgebreide literatuurstudie een lijst met door ree geprefereerde voedselplanten. Op basis van deze lijst is te verwachten dat ze een effect kunnen hebben op ruige veldbies en bramen. Vooral bramen zijn erg geliefd door reeën, maar of er ook verschil is in preferentie tussen het grote aantal soorten bramen is niet bekend. 
In diverse oude loofbosopstanden in Polen, waar edelhert en ree voorkwamen met een dichtheid van respectievelijk ca. 7 en 2 dieren per 100 ha, bleken pony's een positief effect te hebben op de soortdiversiteit in de kruidlaag (Boiko et al., 2019). De hoogte van de kruidlaag verschilde daarbij niet significant tussen bossen met en zonder pony's. Voor specifieke soorten zijn de effecten echter variabel. Voor hengel werd geen verschil gevonden, terwijl het donkersporig bosviooltje (Viola reichenbachiana), en zeer nauw verwant aan het bleeksporig bosviooltje ( $V$. riviniana), alleen voorkwam in loofbossen met pony's. Dalkruid had een hogere bedekking in bossen waar geen pony's voorkwamen. Ook Marozas et al. (2011) vonden in Litouwen dat binnen enclosures met damherten in hoge dichtheden (20-63 dieren op $63 \mathrm{ha}$ ) na vijf jaar dalkruid sterk was afgenomen of geheel verdwenen. Tot slot vonden Martin et al. (2010) in een studie naar geïntroduceerde zwartstaartherten (Odocoileus hemionus) op eilanden voor de kust van Brits Columbia (Canada) dat het NoordAmerikaanse dalkruid (Maianthemum dilatatum) alleen voorkwam op eilanden zonder herten. Dit lijkt erop te duiden dat dalkruid gevoelig is voor begrazing door hoefdieren. In een review van studies over dieetkeuze van edelhert vermeldden Gebert \& Verheyden-Tixier (2008) dat Liliacaea (familie van lelieachtigen) onderdeel uitmaken van het dieet van edelhert, maar niet bekend is of dit dalkruid betreft. Als enige andere (bijzondere) kwaliteitssoort is grote muur genoemd als gegeten soort door edelhert.

In de hierboven aangehaalde studie van Marozas et al. (2011) werd verder vastgesteld dat hoge dichtheden van damhert leidde tot afname van frambozen, klaverzuring en bosbes. Pellerin et al. (2010) vonden tijdens een driejarige exclosure-studie in Frankrijk een afname van de soortdiversiteit in de kruidlaag en een afname van bosanemonen en bramensoorten als gevolg van begrazing door ree en edelhert.

In een review van effecten van begrazing op de bodemflora van Britse bossen vonden Mitchell \& Kirby (1990) en Kirby (2001) dat toenemende graasdruk over het algemeen ten koste gaat van hogere kruiden, varens en (dwerg)struiken, en dat grasachtigen en lage kruiden profiteren van de hogere lichtbeschikbaarheid als gevolg van de reductie door begrazing van de hogere (langere) soorten. Kirby (2001) geeft een lijst met soorten die positief of negatief reageren op begrazing. Van de (bijzondere) kwaliteitssoorten wordt ruige veldbies, bosanemoon en bleeksporig bosviooltje bevoordeeld door begrazing, terwijl de grotere valse salie en braam negatief door begrazing worden beïnvloed.

Al met al is er weinig bekend over de gevoeligheid van (bijzondere) kwaliteitssoorten voor begrazing door hoefdieren. Er zijn sterke aanwijzingen dat dalkruid negatief wordt beïnvloed door begrazing, evenals bramen.

\subsection{Verstoring in vegetatie en bodem}

\subsubsection{Vraat aan knoppen en bladeren}

Bomen en struiken vormen een belangrijke voedselbron voor hoefdieren. Bij loofbomen concentreert de blad- en knopvraat zich vooral in het voorjaar en de vroege zomer, terwijl naaldbomen het meest in de late winter worden aangevreten (Groot Bruinderink et al., 1997b; Odermatt, 2014; Moore et al., 2000).

Het directe effect van vraat is het verlies van bladoppervlak, wat tot groeiverlies van de plant leidt. Het verlies aan bladeren en knoppen kan, vooral bij loofbomen, weer worden gecompenseerd door het uitlopen van (slapende) knoppen en/of adventiefknoppen, of doordat overlevende zijscheuten de groei overnemen. Vraat aan kiemplanten of heel jonge boompjes zal meestentijds leiden tot directe sterfte, maar op oudere leeftijd kunnen houtige planten vraat goed weerstaan, mits de groeiomstandigheden gunstig zijn (zie Figuur 18). Eik en beuk kunnen vele tientallen jaren van intensieve vraat goed overleven, maar bij soorten als es en gewone esdoorn leidt herhaaldelijke vraat snel tot sterfte (Harmer, 2001). Verder kunnen hoefdieren selectief zijn in hun keuze welke individuen worden aangevreten. Zo vonden Moore et al. (2000) dat damherten bij voorkeur bomen aanvreten die daarvoor ook al werden aangevreten. Dit kan duiden op individuele verschillen in smaak- of voedingsstoffen in de plant, maar kan ook het gevolg zijn van de betere voedselkwaliteit van de teruggroeiende scheuten na eerdere vraat. 
Het belangrijkste effect van blad- en knopvraat treedt op wanneer de leidende eindscheut wordt aangevreten. Hierdoor wordt de hoogtegroei belemmerd (Gill, 1992b; Harmer, 2001), waardoor aangevreten bomen een concurrentienadeel ondervinden ten opzichte van bomen die niet worden aangevreten. Hoewel topvraat dus geen directe bedreiging is voor het overleven van een individu zal, in situaties waarin dit individu omringd wordt door soorten die minder worden aangevreten, uiteindelijk de vertraagde hoogtegroei door toenemende overschaduwing leiden tot verminderde concurrentiekracht. Dit is een belangrijk mechanisme achter de effecten van begrazing op de Veluwe, waar in de verjonging vaak een aandeel voor hoefdieren onsmakelijk naaldhout aanwezig is. Een hoge vraatdruk op de smakelijke loofbomen leidt dan uiteindelijk tot dominantie van naaldbomen, zelfs wanneer hun aandeel in de verjonging aanvankelijk relatief laag was.

Verjonging van bomen en struiken is het kwetsbaarst voor vraat zolang de topscheut binnen bereik is van de hoefdierbekken. Hertachtigen vreten het liefst bladeren en knoppen die zich op schouderhoogte bevinden. Voor ree ligt deze rond $75 \mathrm{~cm}$, en bij edelhert rond de $100 \mathrm{~cm}$ (Renaud et al., 2003). Edelhert reikt het hoogst (tot ongeveer $1.75 \mathrm{~m}$; Renaud et al., 2003) en ree het laagst (tot $1.30 \mathrm{~m}$; Van Dongen, 2005). Het damhert zit daartussenin. Dit betekent dat alle vraat onder de $1.30 \mathrm{~m}$ niet aan een van deze soorten specifiek kan worden toegerekend.

\subsubsection{Bastvraat}

Boombast vormt een belangrijk onderdeel van het dieet van hoefdieren. Vooral edelhert en wisent kunnen grote aantallen bomen schillen, waarbij de bast in repen van de stam wordt getrokken. Dit leidt tot blootstelling van het cambium en hout aan schimmelaantastingen. Er zijn verschillende verklaringen waarom herten bomen schillen. Reijnders \& van der Veen (1974) relateren schillen aan een behoefte aan ruwe vezel als aanvulling op makkelijker verteerbaar voedsel. Bast wordt dan gebruikt om te herkauwen, waarmee door speekselvorming voorkomen wordt dat de maag te veel verzuurt. Daarnaast bevat bast relatief veel suiker, zodat het ook als directe voedselbron dient wanneer ander voedsel schaars is. De hypothese dat schillen ontstaat door stress, bijvoorbeeld door verstoring of verveling, wordt niet ondersteund door onderzoek (Gill, 1992a; Rheinberger en Suter, 2006). Verlengde blootstelling, bijvoorbeeld in daginstanden, kan uiteindelijk wel leiden tot hoge percentages geschilde bomen (zie Figuur 9).

Boomsoorten zijn in verschillende mate gevoelig voor schillen, met wilg, es, fijnspar en wilde lijsterbes als veelgenoemde voorkeursoorten en linde, haagbeuk, eik en berk als minder vaak geschilde soorten (Gill 1992a). Welke soorten er daadwerkelijk worden geschild is weer sterk afhankelijk van de lokale soortensamenstelling (Fehér et al. 2016). Op de Veluwe zijn vooral (fijn)sparren, reuzenzilverspar, douglas en beuk relatief gevoelig voor bastvraat. Ook grove den wordt geschild (Reijnders \& Van der Veen, 1974). Verschillen tussen soorten staan in verband met de bastdikte en ruwheid van de schors, maar ook verschillen in aantrekkelijkheid (smaakstoffen, voedselkwaliteit) kunnen een rol spelen.

Bomen worden hoofdzakelijk op jonge leeftijd geschild, wanneer de schors nog relatief glad is. De periode waarover bomen gevoelig zijn voor schillen lijkt vooral afhankelijk van de bastdikte, ruwheid van de schors en de groeisnelheid (Gill, 1992a; Kuiters et al., 2006). Studies uit Midden-Europa laten zien dat bomen meestal geschild worden wanneer zij een diameter hebben van rond de $15 \mathrm{~cm}$ (Rheinberger en Suter, 2006) en dat wanneer de diameter toeneemt van 10 naar $40 \mathrm{~cm}$, de kans op schillen afneemt van 40 naar 10\% (Vospernik, 2006). Hieruit komt duidelijk naar voren dat bastvraat vooral relevant is in opstanden in de dichte en stakenfase.

Bastvraat leidt alleen bij uitzondering tot de dood van de boom (Gill et al., 2000) en heeft daarmee relatief weinig direct effect op de soortensamenstelling en dichtheid van het bos. Bovendien speelt het vooral een rol in de dichte en stakenfase van het bos, waarin ook als gevolg van onderlinge concurrentie de sterfte onder bomen hoog is. Opvallend is dat binnen een opstand de verdrukte bomen relatief vaker worden geschild dan dominante bomen (Rheinberger en Suter, 2006; Reijnders en van der Veen, 1974). Dat kan gekoppeld worden aan een tragere groei en daarmee dunnere schors (Gill, 1992a; Vospernik, 2006). Het is onwaarschijnlijk dat bastvraat een belangrijke sturende rol speelt in de soortensamenstelling van boshabitattypen. Eiken worden nauwelijks geschild en beuk wordt alleen bij een hoge wilddruk, in combinatie met weinig alternatieve voedselbronnen, geschild. Voor hulst lijkt bastvraat uiteindelijk wel tot een relatief hoge sterfte te kunnen leiden in beukenbossen met hoge wilddruk (Den Ouden, pers. obs.). 
De belangrijkste consequentie van bastvraat vindt plaats in de context van productiebos vanwege het nadelige effect op stamkwaliteit door rot of verkleuring. Bij kleinere bomen kan de wond weer snel overwald raken, waardoor er nauwelijks gevolgen zijn voor de groei en stamkwaliteit van de boom (Reijnders en Van der Veen, 1974; Gill, 1992b), maar bij grote schilwonden duurt het meerdere jaren voordat de wond is overwald en ontstaat een rotte plek in de stamvoet met sterkteverlies in het hout tot gevolg. Schimmelaantasting door rot en houtverkleuring leiden tot kwaliteitsverlies van het onderste stamdeel (1-1,5 m lengte), waardoor deze aan houtwaarde inboet. Zeker wanneer potentiële of reeds aangewezen toekomstbomen worden geschild, leidt dit tot productieverliezen.

\subsubsection{Bodemwoeling en compactie}

Hoefdieren hebben naast bovenvermelde effecten ook effect op ecosystemen door fysieke bodemverstoring via betreding en het omwroeten van de bodem (Groot Bruinderink \& Hazebroek, 1996; Reimoser, 2003; Sitters \& Andriuzzi, 2019; Groot Bruinderink et al., 2009). Het wroeten van zwijnen kan als onderdeel worden gezien van het bosecosysteem. Meestal is de oppervlakkige verstoring door wroeten een terugkerend fenomeen (vooral in mastjaren) en als een systeemkenmerk op te vatten. $\mathrm{Bij}$ een groei van de zwijnenpopulatie zullen echter meer locaties, die voorheen periodiek met rust gelaten werden, herhaaldelijk worden omgewroet. Sütő et al. (2019) bestudeerden het wroetgedrag van zwijnen in Hongarije gedurende de periode oktober 2016-april 2019. Hoewel niet bekend is hoe hoog de dichtheid was van wilde zwijnen geeft deze studie wel een indicatie dat het omgewroete oppervlak en de frequentie hoog kunnen zijn: slechts $9 \%$ van het oppervlak werd gedurende de studie niet verstoord en $15 \%$ werd herhaaldelijk omgewroet. De meeste wroetactiviteit (72\%) betrof oppervlakkig wroetgedrag in de strooisellaag.

Zwijnenactiviteit en de daarmee samenhangende gevolgen voor het humusprofiel, de bodem en de biodiversiteit zijn in zekere mate locatiespecifiek. Hoe groot het effect van bodemomwoeling is, hangt af van de vegetatie en groeiplaats (abiotische omstandigheden zoals gelijk moedermateriaal, gelijke hydrologie, bodem en geomorfologie) en de frequentie en aard van het wroeten. Onder naaldbomen kan verstoring van het humusprofiel in theorie de verjonging van boomsoorten bevorderen die het liefst in minerale grond kiemen, zoals grove den, beuk en berk (Groot Bruinderink \& Hazebroek, 1996). Uit vergelijking van het omgewroete oppervlak per opstandtype blijkt uit Groot Bruinderink \& Hazebroek (1992) dat onder eik en beuk het meest verstoord wordt. Wroeten door zwijnen bij dichtheden van 3-4 per 100 ha leidde tot negatieve effecten op verjonging van eik en beuk (Groot Bruinderink et al., 1997a). Daarnaast heeft wroeten effect op de gelaagdheid van het humusprofiel. Dit effect is het grootst in oude bossystemen met dikke humusprofielen of in armere bostypen waarin humus zich opstapelt op de bodem. Hierdoor veranderen de concurrentieposities tussen soorten in de ondergroei (bijvoorbeeld tussen bochtige smele en bosbes), verandert de vochthuishouding en wordt de biodiversiteit beïnvloed. Regelmatige verstoring leidt uiteindelijk tot een verlies aan soorten in het bosecosysteem (Barrios-Garcia \& Ballari, 2012; Mohr et al., 2005; Wirthner et al., 2012).

Kennis over de effecten op individuele soorten, en dan met name de (bijzondere) kwaliteitssoorten van de boshabitattypen, is weinig voorhanden. Een veelgenoemd (zie bijvoorbeeld Bijlsma et al., 2008) effect van het wroeten van wild zwijn betreft het vliegend hert (Lucanus cervus), waarvan de larven en poppen een geliefde prooi zijn van wild zwijn. Echter, duidelijke bewijzen dat wild zwijn de populaties vliegend hert sterk negatief beïnvloedt, zijn in de literatuur niet aangetroffen. In algemene zin heeft begrazing ook een negatief effect op populaties reptielen (Stumpel, 2004), maar ook hier is het effect van wild zwijn op populaties van de hazelworm onduidelijk (Groot Bruinderink et al., 2009). Een hoge wroetintensiteit heeft verder waarschijnlijk een sterk negatieve impact op het voorkomen van mycorrhiza-vormende paddenstoelen (Groot Bruinderink et al., 2009), wat vooral relevant kan zijn voor de typische paddenstoelensoorten van het Oude eikenbos. Nader onderzoek moet hier meer duidelijkheid over geven. Tot slot melden Bijlsma et al. (2008) dat de huidige hoge wroetintensiteit in met name Oude eikenbossen leidt tot negatieve effecten op hengel (en daarmee de bosparelmoervlinder) en verschillende bodemmossen. 
Er is nog weinig onderzoek gedaan naar het relatieve belang van de verschillende processen en kwantitatieve gegevens over de voor planten optimale dichtheden van wilde zwijnen voor verschillende habitat- dan wel landschapstypen, ontbreken (Groot Bruinderink et al., 2009). Wel concluderen zij dat de toentertijd hoge stand van het wild zwijn op de Veluwe leidde tot verstoring van kwetsbare oude bosecosystemen met van oorsprong dikke humusprofielen. Sindsdien zijn de aantallen wilde zwijnen op de Veluwe verder toegenomen en wordt de bodem in eiken-, beuken-, lariks- en douglasbossen zeer frequent en grootschalig nagenoeg vlaktegewijs omgeploegd. Van een stimulerend effect op de bosverjonging of diversiteit aan ondergroei is bij de huidige dichtheid aan wild zwijn geen enkele sprake. Bovendien leidt het intensieve wroeten tot verlies aan bodemkundige waarden en heeft het grote gevolgen voor de koolstofvoorraad die in de bodem wordt opgeslagen (zie o.a. Den Ouden et al., 2020; Risch et al., 2010). Ook bossen met adelaarsvaren in de ondergroei worden door zwijnen vrijwel jaarlijks volledig omgeploegd op zoek naar wortelstokken. Dit is voor de populatie adelaarsvaren geen echte bedreiging, omdat nieuw blad uit resten van wortelstokken kan groeien. De dominantie van adelaarsvaren wordt hierdoor wel tijdelijk doorbroken, hetgeen vestigingsmogelijkheden biedt voor allerlei plantensoorten. Deze nieuwe verjonging wordt echter vaak de volgende winter weer tenietgedaan.

Betreding door hoefdieren kan een groot effect hebben op de bodemstructuur, op bodemprocessen en op de bodemfauna (Sitters \& Andriuzzi, 2019). Wanneer bodemverdichting optreedt, heeft dit vooral effect op het vocht- en zuurstofgehalte in de bodem, vooral op rijkere (klei)bodems. Dit kan in veel begraasde ecosystemen leiden tot een vleksgewijze verspreiding van plantensoorten. Veelal zijn deze effecten lokaal van aard, bijvoorbeeld op veelgebruikte wissels. Bij hoge dichtheden van grazers (rund, paard, maar ook grote roedels herten) kan de impact echter groter zijn. Onderzoek op de Veluwe toonde onlangs aan dat het uitsluiten van hoefdieren via exclosures leidt tot een minder verdichte bodem, ongeacht de dichtheid van hoefdierpopulaties buiten de exclosures (Ramirez, 2019). Hoefdieren kunnen een effect hebben door het selectief verplaatsen van nutriënten middels hun mest (bv. foerageren in het bos en de mest achter laten op grasland). Daarbij kan, afhankelijk van hun dieetkeus met een bepaalde mineralenverhouding en terreingebruik, een verschuiving optreden in $\mathrm{N}$-, $\mathrm{P}-$, of $\mathrm{N}$ - en $\mathrm{P}$ - gelimiteerde situaties, waardoor er effecten optreden op de groeiomstandigheden voor plantensoorten (zie o.a. Bokdam, 2003). Over de effecten op bodemprocessen en de bodemfauna en de daarmee samenhangende effecten op het voedselweb en ecosysteem, is nog onvoldoende bekend.

\subsection{Gevolgen voor overleving en groei}

De effecten van wilddruk op de bosverjonging worden gewoonlijk gedemonstreerd met behulp van exclosures. Het effect van grote herbivoren wordt dan afgeleid uit het verschil in bosontwikkeling tussen gebieden die normaal kunnen worden bezocht (de controle) en vergelijkbare gebieden die ontoegankelijk zijn gemaakt voor grote herbivoren (de exclosures). Op de korte termijn maakt dit direct inzichtelijk in welke mate de verjonging van boomsoorten wordt beïnvloed door grote herbivoren. Op de langere termijn ontstaat echter een geheel verschillende structuur tussen exclosures en daarbuiten, waardoor het milieu in de ondergroei sterk verschilt en ook weer gevolgen heeft voor de soortendiversiteit van de kruidlaag (Sabo et al., 2017).

In het kader van een groot bosbegrazingsonderzoek in de jaren 1980 en 1990 (Van Wieren et al., 1997) werd in het Staatsdomein bij Het Loo op een oppervlak van 1250 ha de toenmalige hoefdierenstand gereduceerd tot ca. 5 edelherten, 6,5 reeën en 2,5 wilde zwijnen per 100 ha. Het effect daarvan werd onderzocht door middel van exclosures in verschillende bostypen over een periode van 10 jaar. Conclusie van deze studie was dat bij de nieuwe standen de wilddruk nog steeds een sterk remmende invloed had op de spontane verjonging van struik- en loofboomsoorten en dat naaldbomen een sterk concurrentievoordeel verkregen door begrazing. Relatief smakelijke soorten als eiken, berken en wilde lijsterbes wisten zich buiten de exclosures niet te verjongen (Kuiters \& Slim, 2002).

In het Nationale Park De Hoge Veluwe werd door Smit et al. (1998) onderzoek gedaan naar de effecten van het verwijderen van het binnenraster van het Park, waarmee het leefgebied van het edelhert werd uitgebreid van de voormalige wildbaan tot het gehele Park (met uitzondering van het centrumgebied). Exclosures werden geplaatst in gebieden waar edelhert en moeflon werden 
geïntroduceerd of reeds aanwezig waren en deze werden over een periode van zeven jaar gevolgd. De geschatte dichtheden aan herbivoren (per $100 \mathrm{ha}$ ) was in de eerste jaren na verwijdering van het binnenraster ca. 5,5 edelhert, 5,5 moeflon, 4 ree en 1-4,5 wild zwijn. Edelhert bleek het sterkste effect op de verjonging te hebben. Binnen de exclosures groeide tijdens de onderzoeksperiode een diverse struiklaag op, terwijl buiten de exclosures de smakelijke boomsoorten (met name wilde lijsterbes en Amerikaans krentenboompje) sterk in hoogtegroei werden belemmerd en de bestaande struik- en jonge boomlaag van genoemde soorten zelfs werden gereduceerd. Bij introductie van edelhert werd de bestaande struiklaag sneller gedegradeerd dan dat de beschermde struiklaag in de exclosures zich kon herstellen. De conclusie was dat vanuit het oogpunt van natuurbehoud, de introductie van begrazing in bossen geen succesvolle maatregel is voor het behouden of ontwikkelen van een hogere diversiteit aan soorten of levensgemeenschappen (Smit, 2002).

Goudzwaard et al. (2001) onderzochten effecten van vraat in relatie tot dunning in een gemengd grove dennen-eikenbos in Boswachterij Ugchelen-Hoenderloo. Op basis van keuteltellingen en zichtwaarnemingen werden dichtheden aan herbivoren buiten de exclosures geschat op ongeveer 2 edelhert per 100 ha en 4-5 reeën per 100 ha. Binnen exclosures verjongden grove den, berk, eik, beuk, wilde lijsterbes en vuilboom, terwijl buiten de exclosures de verjonging van wilde lijsterbes en vuilboom sterk achterbleef. Wilde lijsterbes en vuilboom waren buiten de exclosures in vergelijkbare aantallen aanwezig als binnen exclosures, maar werden in hoogtegroei sterk belemmerd. Ook hoogtegroei van berk werd door begrazing gereduceerd. Buiten de exclosures bepaalden vooral beuk en wintereik de verjonging. Eindconclusie was dat edelhert en ree de verjonging van loofbomen sterk belemmerden.

Ramirez et al. (2019) onderzochten de langetermijneffecten van wilddruk aan de hand van exclosures en controleplots. De exclosures werden 1-33 jaar geleden opgericht en lagen verspreid over de gehele Veluwe. De wilddruk op de controleplots was navenant sterk gevarieerd. De soortenrijkdom nam in de tijd sterk af in de controleplots en de sterkst beïnvloede soorten als gevolg van begrazing waren, in afnemende volgorde, wilde lijsterbes, vuilboom, Amerikaans krentenboompje en eik. Naaldbomen werden als groep duidelijk minder aangevreten. Binnen de exclosures nam de dichtheid van het kronendak sterker toe, waardoor de bedekking van de kruidlaag negatief werd beïnvloed. Dit had ook gevolgen voor het ecosysteem in bredere zin: door de verminderde dichtheid van zaailingen als gevolg van begrazing nam het aantal knaagdieren af (dit werd ook geconstateerd door Kuiters et al. (1997) en door Smit et al. (2001)), aanwezigheid van hoefdieren zorgde voor bodemcompactie en leidde tot een verminderde strooiseldikte, met daaraan gekoppeld een lagere diversiteit van de bodemfauna, lagere mineralisatiesnelheden van magnesium en stikstof in strooisel van eik en grove den.

Op dit moment loopt een nieuw onderzoek naar de effecten van hoefdieren op de bosverjonging binnen het Nationale Park De Hoge Veluwe. Hierbij is een serie nieuwe exclosures geplaatst en wordt een netwerk van permanente plots sinds 2012 jaarlijks gemonitord. Daarnaast zijn door Staatsbosbeheer nieuwe exclosures geplaatst in de leerboswachterijen Oostereng, Rozendaalse Bos en Speulderbos. De resultaten zijn tot nu toe verschenen als studentenrapporten in het kader van afstudeeropdrachten van Wageningen Universiteit, Van Hall-Larenstein en de Universiteit van Amsterdam (zie onder andere Wonders, 2014; Verbeek, 2016; Maug, 2019; Vink, 2020). Uit dit onderzoek komt eenzelfde beeld naar voren als uit de voorgaande onderzoeken, met in de meeste gevallen een sterke reductie in dichtheid en hoogtegroei van smakelijke loofboomsoorten als wilde lijsterbes en vuilboom, en zeer lage vraat aan naaldbomen, waardoor de samenstelling van de bosverjonging sterk wordt beïnvloed door hoefdieren in het voordeel van onsmakelijke naaldbomen. Voorts blijkt dat vraatpercentages van jaar tot jaar sterk kunnen fluctueren, zelfs bij gelijkblijvende hoefdierdichtheden. Dit was onder andere gerelateerd aan het voorkomen van een sneeuwdek in de winter, wat leidde tot een toename van vraat aan de verjonging (Wonders, 2014).

In het bosreservaat Pijpebrandje, een goed ontwikkeld voorbeeld van het habitattype Beukeneikenbossen met hulst, is in 2013 een groot, permanent plot van 27 ha ingericht voor het volgen van de langjarige bosontwikkeling (Anderson-Teixera et al., 2014). Een recente heropname (20 ha) van dit plot liet zien dat de ingroei van verjonging erg laag was. In totaal groeiden in 5 jaar tijd 169 jonge bomen tot voorbij de $1 \mathrm{~cm}$ stamdiameter (gemeten op $130 \mathrm{~cm}$ hoogte). Van deze jonge bomen bestond het merendeel uit lariks en douglas (samen $85 \%$ ). De resterende verjonging bestond uit beuk, de dominantste boomsoort in dit reservaat, en verder werd een nieuwe hulst aangetroffen. 
Kuiters et al. (2000) onderzochten de mate van vraat aan verjonging in een zestal bosreservaten, waaronder ook Pijpebrandje. Zij constateerden dat in het beukenbos van het Pijpebrandje de verjongingsdichtheid erg laag was en bovendien meestal sterk was aangevreten. Dit onderzoek vond plaats in een periode waarin de wilddruk van met name edelhert en wild zwijn aanzienlijk lager was dan in het afgelopen decennium (zie Figuur 21).

Bovenstaande onderzoeken laten allemaal zien dat er bij de huidige wildstanden sprake is van een sterke belemmering van de verjonging van veel loofboomsoorten en dat de voorkeur van hoefdieren voor loofbomen ten opzichte van naaldbomen leidt tot een verschuiving in de aandelen van beide groepen (Stokely \& Betts, 2020; Ramirez et al., 2019). Naarmate de populatiedichtheid van grote herbivoren toeneemt, neemt de beschikbaarheid van de geprefereerde soorten af en verschuift de voedselkeuze naar minder geprefereerde soorten (Frerker et al., 2013). Bij een toename van grote herbivoren wordt ook de dichtheid van de verjonging steeds lager. De verlaging van de dichtheid in de verjonging heeft uiteindelijk weer een stimulerend effect op de ondergroei. Door de hogere lichtbeschikbaarheid zijn meer soorten in staat te overleven in de ondergroei, waardoor de diversiteit en bedekking hoger kunnen zijn dan wanneer hoefdieren aanwezig zijn (zie bijvoorbeeld Nessing \& Zerbe, 2002; Buttenschøn \& Buttenschøn, 2013).

\subsection{Dosis-effectrelaties}

Een probleem met het gebruik van exclosures (rasters) om effecten van wilddruk te meten, is het feit dat binnen een exclosure altijd een nulstand aanwezig is (geen enkele invloed van grote herbivoren), terwijl buiten de exclosures de vegetatie wordt beïnvloed door een vaak sterk variabele dichtheid en samenstelling van grote herbivoren. Voor het bepalen van het niveau van wilddruk dat acceptabel is met betrekking tot de realisatie van een terreindoel, is het nodig inzicht te hebben in de relatie tussen de feitelijke wilddruk op een locatie en de effecten daarvan op de vegetatie.

Kuiters \& Slim (2002) concluderen dat een aantalsreductie van hoefdieren van $2600 \mathrm{~kg}$ per 100 ha naar $500 \mathrm{~kg}$ per 100 ha zou leiden tot bossen die gedomineerd worden door grove den en beuk. De reductie leidde wel tot een toename van de struiklaag en meer verjonging. De verlaagde aantallen hoefdieren (4,8 edelhert per 100 ha, 2,4 wild zwijn per 100 ha en 6,4 ree per 100 ha) waren echter te hoog om succesvolle verjonging van eik mogelijk te maken. Deze dichtheden liggen in de range van de huidige situatie op de Veluwe (zie paragraaf 5.1). Kuiters \& Slim (2002) postuleren dat ruimtelijke en temporele fluctuaties in de wilddruk nodig zijn om verjonging van eik te realiseren.

Een hoge intensiteit - gedurende lange tijd - van begrazing, wroeten en browsen door hoefdieren kan verschuivingen veroorzaken in de soortensamenstelling van plantengemeenschappen en kan het functioneren van het ecosysteem veranderen (Tanentzap et al., 2012). Het verminderen van de aantallen hoefdieren zou deze veranderingen in theorie kunnen terugdraaien, maar in de praktijk kan de nieuwe situatie zeer lang blijven bestaan, waarbij een terugkeer naar de uitgangssituatie niet of slechts op zeer lange termijn wordt bereikt. Vooral op nutriëntarme bodems kan het veel langer duren voor de effecten van hoefdieren zijn teruggedraaid. Aanvullend bosbeheer, zoals dunnen, zou dan noodzakelijk kunnen zijn.

Ramirez et al. (2018) evalueerden 433 publicaties op de effecten van hoefdieren op bossen in de gematigde klimaatzone. Op basis van de gevonden literatuur modelleerden ze een dosis-effectcurve op basis van metabolische lichaamsgewichten (MBW, berekend als het lichaamsgewicht tot de macht 0.75 ) van hoefdieren en semi-kwantitatieve parameters met betrekking tot het functioneren van bossen. Bij een hoefdierbiomassa van $115 \mathrm{~kg}$ MBW per 100 ha ontstaan significante effecten in de bosverjonging, bij $141 \mathrm{~kg}$ per 100 ha wordt de structuur van het bos aangetast en bij $251 \mathrm{~kg}$ MBW per 100 ha wordt de nutriëntencyclus negatief beïnvloed. Onderzoek van Brouwers (2004) en van Wubben (2005) naar vraatpercentages aan verjonging op plekken met verschillende wilddichtheden op de Veluwe liet zien dat er bij de genoemde $115 \mathrm{~kg}$ MBW per 100 ha al aanzienlijke vraatpercentages aan de verjonging optreden. Van Dongen (2005) heeft de dosis-effectrelatie bestudeerd voor ree in NoordBrabant. Wanneer alleen ree aanwezig is, ligt het omslagpunt bij nog minder dieren (uitgedrukt in MBW). 
Bovenstaande impliceert dat, wanneer alleen edelherten aanwezig zijn en geen andere hoefdieren, bij een dichtheid van 2-3 edelherten per 100 ha, in zijn algemeenheid bosverjonging en de structuur van bos negatief kunnen worden beïnvloed. Deze grove indicatie komt overeen met de resultaten van Van Wieren \& Kuiters (1997). Zij concluderen in een modelstudie met het bosbegrazingsmodel FORGRA dat er altijd een effect op de bosverjonging is, zelfs bij lage dichtheden waarbij alleen reeën aanwezig zijn met een dichtheid van 1 ree per 100 ha. Bij hogere dichtheden, waarbij alleen edelherten aanwezig zijn met een dichtheid van 3-10 per 100 ha, verdwijnt de verjonging van eik en beuk in wintereiken-beukenbos op holtpodzolen en in berken-zomereikenbos op stuifzand. Runderen hadden in alle bostypen een groot effect bij dichtheden van 1-8 per 100 ha en leidden tot het verdwijnen van verjonging. Met betrekking tot het wild zwijn konden geen conclusies worden getrokken over de langetermijnontwikkeling. Op de korte termijn wordt gesteld dat bij dichtheden van 2 zwijnen per 100 ha een zwak negatieve invloed op de verjonging van eik en beuk optreedt. Groot Bruinderink \& Hazebroek (1996) constateerden dat bij dichtheden van 2-4 wilde zwijnen per 100 ha de frequentie van omgewroete plekken te hoog is om kieming en vestiging van struik- en boomsoorten te bestendigen.

In een andere modelstudie gebruikten Groot Bruinderink et al. (2004) het model FORSPACE om het effect van het ontbreken van hoefdieren en het effect van lage dichtheden hoefdieren ( 1 per 100 ha) op Veluwezoom over een periode van 50 jaar door te rekenen. Het verwijderen van hoefdieren en het terugbrengen van de dichtheid aan hoefdieren was gunstig voor beuk. Het voorkomen van eik werd al beïnvloed bij lage dichtheden (1 per $100 \mathrm{ha}$ ).

Gill \& Morgan (2010) stellen op basis van een studie aan bosverjonging in het Verenigd Koninkrijk dat bij een dichtheid die lager is dan ca. 1,4 herten per 100 ha er genoeg verjonging (voornamelijk eik) in bestaande opstanden is om bos in stand te houden. Bij hogere dichtheden is dit niet (altijd) mogelijk. Een onderscheid naar de effecten per soort (ree, damhert etc.) die geanalyseerd werden in de studie was niet mogelijk. Op basis van een berekening aan de voedselbehoefte en voorkeur van edelhert op het Nationale Park De Hoge Veluwe berekenden Smit et al. (1998) dat voor het verkrijgen van verjonging van eik en wilde lijsterbes een stand van maximaal 1,2 edelhert per 100 ha mogelijk is.

Op basis van bovenstaande literatuur zou de dichtheid van alle hoefdieren samen in de orde van grootte van 1-2 per 100 ha moeten liggen, wil er sprake zijn van een onbelemmerde verjonging van alle boomsoorten. Dit komt overeen met de algemene vuistregel in Duitsland dat economische draagcapaciteit voor de bosbouw (lees: het handhaven van gewenste boomsoorten in de verjonging) ligt bij standen van maximaal 1-1,5 edelhert per 100 ha of 4-5 reeën per 100 ha (Wolfe \& Von Berg, 1988). Dergelijke dichtheden zijn slechts indicatief en kunnen, afhankelijk van lokale omstandigheden zoals bodemvruchtbaarheid, hoger of lager liggen. Er is wat dat betreft nog onvoldoende informatie beschikbaar over herbivoor-plantinteracties. De wetenschap staat wat dit betreft nog in de kinderschoenen (Gordon \& Prins, 2019) en onderzoek naar de effecten van hoefdieren op de ondergroei (struik- en kruidlaag) in West-Europa is daarbij grotendeels braakliggend gebied (Schäfer et al., 2019). Monitoring is dus noodzakelijk (hand-aan-de-kraan-principe) om te bezien bij welke aantallen hoefdieren de gestelde terreindoelen met betrekking tot de verjonging van boomsoorten en de aanwezigheid van specifieke plantensoorten kunnen worden gerealiseerd. 


\section{Dynamiek en draagkracht hoefdieren}

\subsection{Populatiedynamiek}

\subsubsection{Reproductie, groei en sterfte}

De populatiedynamiek van (wilde) hoefdieren is complex en van vele factoren afhankelijk. Om een goed beeld te kunnen krijgen van de omvang en dynamiek van populaties, is het noodzakelijk gedegen inzicht te hebben in factoren als voortplanting, sterfte, immigratie en emigratie (Figuur 12). Voor de Veluwe is er door tellingen wel een beeld van de populatietrends, maar niet van de werkelijke populatieomvang, laat staan van de dynamiek, populatieopbouw etc. Dat is voor gedegen beheer wel een belangrijke voorwaarde (Groot Bruinderink \& Van der Grift, 2015; Van der Grift, 2018). Bij het hoefdierbeheer in Nederland gaat het vaak meer om het maatschappelijk draagvlak dan om de feitelijke draagkracht van het terrein (zie paragraaf 4.3). De populaties van de verschillende soorten worden veelal op een lager aantal gehouden (de maatschappelijk gedragen stand waarbij de beleefde schade en overlast acceptabel is) dan de populatiegroottes zouden kunnen zijn gegeven de werkelijke (ecologische) draagkracht van het gebied.

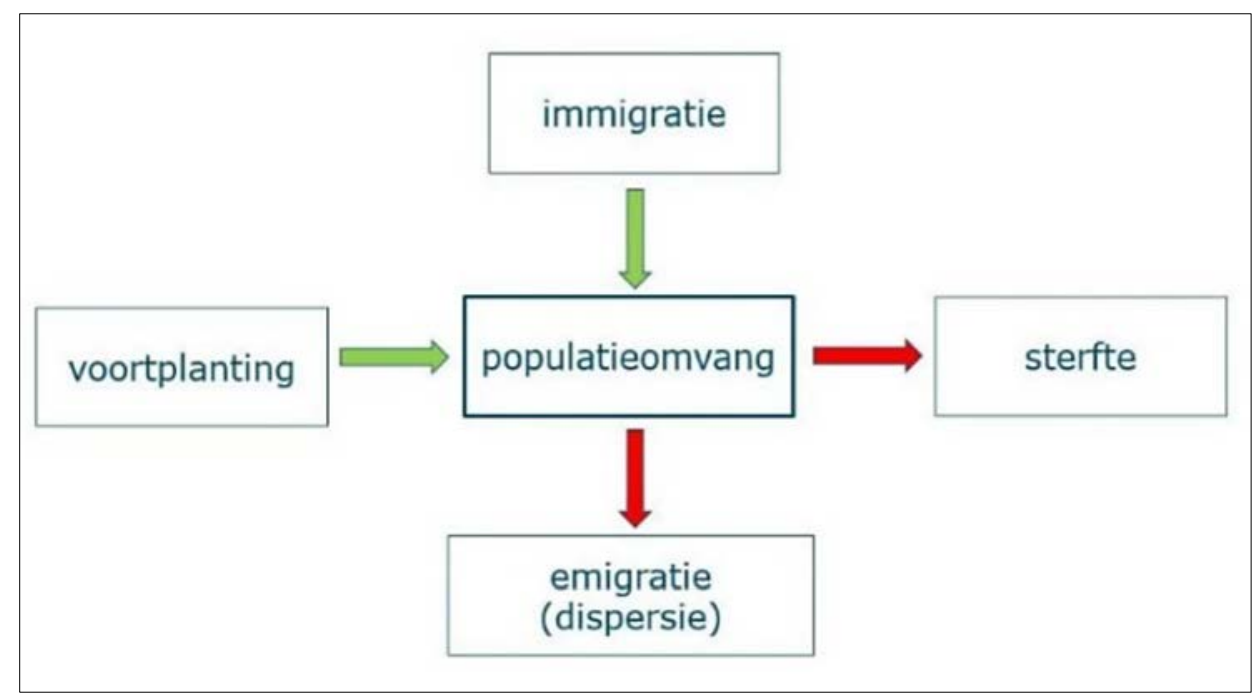

Figuur 12 Factoren die van invloed zijn op de populatieomvang van grote hoefdieren binnen een leefgebied.

Door een jaarlijks afschot van ca $50 \%$ van de edelherten en $70 \%$ van de wilde zwijnen op de Veluwe is de belangrijkste sterftefactor wel duidelijk. Daarnaast sterft jaarlijks een deel als verkeersslachtoffer. Mede door het intensieve beheer worden de hoefdierpopulaties op een veel lager niveau dan de draagkracht gehouden, met als gevolg dat er weinig voedselconcurrentie is en de meeste vrouwelijke dieren jaarlijks bijdragen aan voortplanting. De populatie blijft in de optimale groeifase waardoor er jaarlijks een behoorlijke afschotinspanning vereist is om het aantal op niveau te houden. Edelherten hebben meestal 1 kalf per hinde per jaar. Dat maakt dat deze soort niet heel dynamisch zal zijn qua aantallen. De voortplantingsdynamiek van het wild zwijn is daarentegen veel grilliger. Oudere zeugen kunnen vele biggen werpen. Indien vrouwelijke zwijnen meer dan $25 \mathrm{~kg}$ wegen, kunnen ze vruchtbaar worden en bijdragen aan de voortplanting. Onder gunstige omstandigheden kunnen zeugen per jaar meerdere worpen hebben en biggen uit een vroege worp datzelfde jaar nog bijdragen aan de voortplanting. Kortom: de populatieaantallen van zwijnen schommelen sterk en zijn veel meer van factoren als voedsel en klimaat afhankelijk dan van het edelhert. 


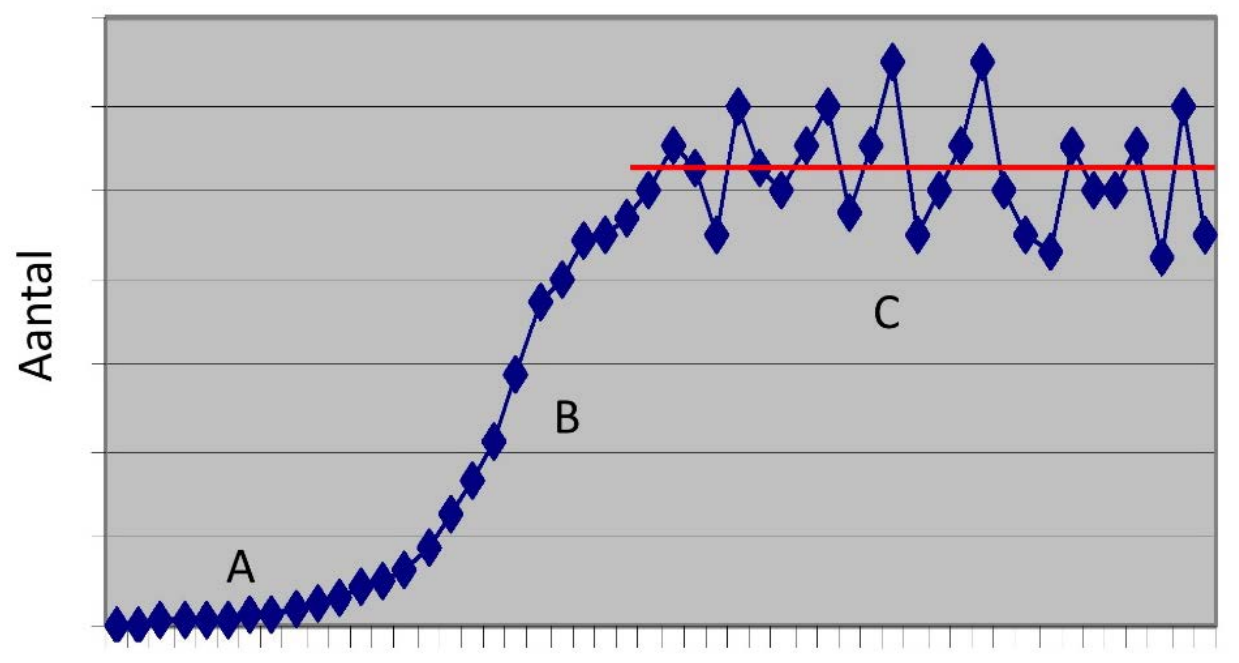

Tijd

Figuur 13 Schematische weergave van een groeicurve van aantallen dieren in een populatie in de tijd met een beginfase $(A)$, de fase van exponentiële groei $(B)$ en een fase van een dynamisch evenwicht $(C)$ waarbij de aantallen fluctueren rondom een gemiddelde (rode lijn).

Een populatie van hoefdieren zal zich in grote lijnen volgens een vast patroon ontwikkelen (Figuur 13). In de beginfase is de populatie gering in aantal en dus kwetsbaar maar ook goed te beheren, want er is weinig aanwas. Dit is de fase waarin de wisenten en wolven op de Veluwe zich nu bevinden. Weet een populatie door deze kwetsbare fase heen te komen, dan bereikt die de exponentiële groeifase. De draagkracht is dan nog niet bereikt en er is weinig onderlinge competitie, dus kan de populatie flink groeien. Op de Veluwe bevinden de populaties van edelhert en wild zwijn zich in deze fase. Dit betekent dat er jaarlijks een forse beheerinspanning nodig is om deze populaties op een bepaald niveau te houden. Indien de populatie vervolgens doorgroeit, zal de populatie zich door competitie, ziekten en natuurlijke selectie stabiliseren rond de draagkracht van de soort of het ecosysteem, waarna de populatie rond een dynamisch evenwicht zal fluctueren. Dit was tot voor kort de situatie met de edelherten in de Oostvaardersplassen. Niet alle vrouwelijke dieren in de populatie doen dan mee aan de voortplanting, omdat ze daarvoor in onvoldoende goede conditie zijn, waardoor een terugkoppelingsmechanisme ontstaat. Daarnaast is in een situatie van een dynamisch evenwicht de natuurlijke sterfte hoog.

Als een populatie zich niet stabiliseert, kan de populatie zeer sterk fluctueren of zelfs crashen. Dit geldt vooral voor wild zwijn (zie ook paragraaf 5.1) en mogelijk ook moeflon en damhert. Bij wild zwijn kan bij een hoge dichtheid na een paar goede mastjaren massale sterfte optreden wanneer de omstandigheden ongunstig worden, zoals een jaar zonder mast of een strenge winter (Briedermann, 2009).

Damherten lijken niet echt een terugkoppelmechanisme te kennen in de vorm van minder reproductie zoals edelherten. Vandaar dat deze populaties langer door kunnen blijven groeien, zoals is waargenomen in de populaties in de Amsterdamse Waterleidingduinen, de Manteling van Walcheren en de Kop van Schouwen (Kuiters \& De Vries, 2016). Het ree is meer solitair en territoriaal, waarbij de territoriumgrootte de dichtheid bepaalt. Behalve populatiedynamica op één soort te betrekken, kan dat ook worden bekeken op ecosysteemniveau, waarbij verschillende soorten interacteren (Kuiters et al., 2005). Met name tussen de verschillende grazers onderling vinden er interessante processen plaats die variëren van concurrentie tot facilitatie (zie paragraaf 4.3). Van ree is bekend dat deze erg gevoelig is voor concurrentie van andere hoefdieren, en deze soort kan zelfs helemaal worden verdrongen, zoals in aangetoond in het Nationale Park De Hoge Veluwe (Smit et al., 1998), de Oostvaardersplassen (Cornelissen, 2017) en de Amsterdamse Waterleidingduinen (Waternet, 2019). 


\subsubsection{Immigratie en emigratie}

Naast voortplanting, groei en sterfte wordt de populatiegrootte ook beïnvloed door immigratie vanuit, of emigratie naar, de populatie (Figuur 13). Dit vereist de vrije verplaatsing van individuen, hetgeen in de sterk doorsneden Veluwe maar zeer beperkt het geval is. Uitgerasterde snelwegen en provinciale wegen, spoorlijnen en ingerasterde landbouwenclaves belemmeren de bewegingen van populaties over de Veluwe. Vanuit het Meerjaren Programma Ontsnippering Natuur (MJPO) is in de afgelopen jaren het nodige gedaan om dergelijke barrières te mitigeren, vooral bij rijkswegen. Ook nu nog worden ecoducten aangelegd, met name over provinciale wegen. Dit is belangrijk om de afzonderlijke deelpopulaties van hoefdieren (en andere flora en fauna) beter met elkaar te kunnen laten uitwisselen en de risico's op inteelt te vermijden.

\subsubsection{Levensvatbare populaties en genetische variatie}

Via natuurherstel en ontsnipperingsmaatregelen wordt gestreefd om populaties in een gunstige staat van instandhouding (SvI) te krijgen of te houden. De belangrijkste vraag daarbij is hoe groot een populatie moet zijn om een verwaarloosbaar klein risico te lopen binnen 100 tot 1000 jaar uit te sterven. Kleine geïsoleerde populaties hebben een verhoogd risico op uitsterven (zie De Groot et al. (2016) voor een nadere uitleg).

De minimale levensvatbare populatieomvang (MVP, uit het Engels: Minimum Viable Population) is de omvang die een populatie minimaal moet hebben om op lange termijn levensvatbaar te zijn, oftewel zich in een gunstige SvI te bevinden. Een populatie moet voldoende groot zijn om door demografische toevalsprocessen niet het risico te lopen uit te sterven. Daarnaast spelen genetische processen. In te kleine populaties loopt geleidelijk de genetische variatie terug, onder andere door inteelt, wat de vitaliteit en het aanpassingsvermogen kan beperken, met als gevolg een verhoogd risico op uitsterven. Een overzicht van deze processen is goed uitgewerkt in De Groot et al. (2014). Om deze risico's te vermijden, is het cruciaal om genetische aspecten mee te laten wegen bij het bepalen van de MVP.

Belangrijk in dit verband is om een onderscheid te maken tussen open populaties, die periodiek uitwisseling kennen met andere populaties, en geïsoleerde populaties, waarbij dergelijke uitwisseling ontbreekt (zoals de Veluwe als geheel). In het algemeen wordt verondersteld dat het binnenkomen van één genetisch afwijkende immigrant per generatie voldoende is om het verloren gaan van genetische variatie op de lange termijn tegen te gaan. Indien sprake is van een populatie die naar verwachting de komende jaren volledig geïsoleerd zal blijven, is op de lange termijn genetische verarming te verwachten. Voor zulke populaties moet worden uitgegaan van een MVP die voldoende groot is om ook toevallige schommelingen in het voorkomen van zeldzamere genvarianten op te vangen. Het Nederlandse natuurbeleid volgt voor het verkrijgen van een gunstige SvI voor bedreigde soorten op hoofdlijnen de opeenvolgende fasen van allereerst het vergroten van het bestaande leefgebied, en vervolgens het verbinden van bestaande leefgebieden. In het uiterste geval wordt conform de IUCN-richtlijnen voor herintroducties een populatie versterkt door dieren bij te plaatsen (Smulders et al., 2006).

\section{MVP edelherten Veluwe}

Het edelhert is een polygame soort, waarbij één man paart met een groot aantal vrouwtjes. Dit resulteert in een situatie waarbij een relatief klein aantal dominante mannetjes betrokken is bij de totale reproductie in de populatie en de kans dus relatief groot is dat twee nakomelingen dezelfde vader hebben. Bij dergelijke polygame diersoorten kan daardoor relatief snel inteelt optreden. De geherintroduceerde Nederlandse otterpopulatie is in dat verband een mooi voorbeeld (zie Koelewijn et al., 2010). Concrete voorbeelden van berekeningen van de verhouding tussen $\mathrm{N}_{\mathrm{e}}$ (effectieve populatiegrootte die aan de voortplanting deelneemt) en $\mathrm{N}_{c}$ (totale populatiegrootte op basis van census) zijn voor het edelhert beperkt beschikbaar. Voor de edelhertenpopulatie te Mesola, Italië, berekenden Zachos et al. (2009) een effectieve populatiegrootte van 15, uitgaande van een totale census van 120 dieren. Reed et al. (1986) kwamen op basis van een gewenste $\mathrm{N}_{\mathrm{e}}$ van 50 reproductieve dieren uit op een MVP van 426 dieren voor een populatie wapiti's in Noord-Amerika, een soort die destijds nog als ondersoort van Cervus elaphus werd beschouwd. Beide studies komen dus uit op een zeer vergelijkbare omrekeningsfactor $N_{e} / N_{c}$ van ongeveer $1 / 8$, oftewel 1 op de 8 dieren in 
de populatie draagt bij aan de voortplanting. Voor de studie uitgewerkt in Van der Grift et al. (2018) resulteerde dit in een MVP van $\sim 400$ dieren in het geval van een open populatie, versus $\sim 4000$ dieren in een geheel geïsoleerde populatie.

Aangezien de Veluwe een gesloten populatie betreft (er is geen uitwisseling met bijvoorbeeld de Oostvaardersplassen of Duitse populaties) betekent dit dat de MVP niet wordt gehaald. Er zijn, op basis van zichttellingen, circa 2500 edelherten op de Veluwe (VWV 2019). Het Faunabeheerplan Grote Hoefdieren 2019-2025 (FBE Gelderland, 2019) meldt dat een aantal van 150 individuen volstaat voor een gunstige SvI, nogal een sterk lager aantal dan bovenstaande berekeningen. Uit een grote genetische studie naar de populaties van edelherten en wilde zwijnen in Nederland en omliggende grensgebieden (De Groot et al., 2016) blijkt dat de genetische diversiteit op de Veluwe minder groot is dan bijvoorbeeld in de Oostvaardersplassen. Daarnaast is er nog steeds een genetische substructuur zichtbaar in de Veluwse edelhertenpopulatie. Dit kan het gevolg zijn van hoe de populaties historisch zijn samengesteld, en op de Veluwe historisch zijn gescheiden in afzonderlijke leefgebieden. Maar ook is het effect van beheer niet uit te sluiten. Dit wordt middels een andere genetische analyse bevestigd (De Jong 2018). In de Oostvaardersplassen doen vrijwel zeker alleen de meest vitale dieren mee aan voortplanting en is er goede uitwisseling tussen de dieren. Op de Veluwe wordt proactief ca. $50 \%$ van de dieren willekeurig geschoten en zijn vrijwel alle hinden jaarlijks drachtig. Dit heeft mogelijk consequenties voor processen als natuurlijke selectie en adaptatie en heeft gevolgen voor de effectieve populatiegrootte. Dat dit laatste van groot belang is, blijkt wel uit een recente studie uit Rum, Schotland waar de onderzochte edelhertpopulatie het worpmoment in 40 jaar met 2 weken had vervroegd als aanpassing aan klimaatverandering (Bonnet et al., 2019). Het is maar de vraag of dergelijke processen zich kunnen voltrekken als jaarlijks dieren op min of meer willekeurige wijze worden verwijderd via afschot.

\section{MVP wild zwijn}

Uit een grote genetische studie naar de populaties van edelherten en wilde zwijnen in Nederland en omliggende grensgebieden (De Groot et al. 2016) blijkt dat de genetische variatie van zwijnen op de Veluwe matig is. Dit wordt middels een andere genetische analyse ook bevestigd door De Jong (2018). Het faunabeheerplan Grote Hoefdieren 2019-2025 (FBE Gelderland 2019) meldt dat 150 individuen volstaan voor een gunstige SvI. Hoewel er geen MVP-bepaling voor wild zwijn is uitgevoerd, is het waarschijnlijk dat dat aantal beduidend hoger zal liggen, zoals ook bij het edelhert. Een modelstudie voor Schotland berekent bijvoorbeeld een MVP voor wild zwijn van 300 individuen (Howells \& Edwards-Jones, 1997).

\section{MVP damhert en ree}

Damherten zijn ooit in kleine aantallen naar Nederland gehaald en kennen een smalle genetische basis (Randi \& Apollonio, 1988). Waarschijnlijk is die variatie altijd al geringer geweest in vergelijking met andere hertachtingen (Baker et al., 2017). In de maatschappelijke beleving zien velen damherten nog als een exoot. Nu de soort als inheems wordt beschouwd, zou op hoofdlijnen iets vergelijkbaars kunnen gelden als hierboven voor edelhert is uitgewerkt. De FBE Gelderland (2019) geeft aan dat voor een MVP een omvang van 40-50 individuen volstaat, maar zoals boven voor edelhert geschetst is, lijkt dit een sterke onderschatting.

Reeën komen ook buiten de Veluwe voor en kunnen dus goed onderling uitwisselen. Zodoende is het probleem van isolatie voor deze soort niet aan de orde.

Voor de korte termijn voldoen de door de FBE Gelderland (2019) gehanteerde MVP's naar verwachting om uitsterven door demografische toevalsprocessen te voorkomen. Voor populaties die op de lange termijn levensvatbaar moeten zijn en in staat om zich aan te passen aan veranderende omstandigheden (klimaatverandering, uitbraken van ziektes), is echter een veel grotere populatieomvang nodig. Daartoe zouden de leefgebieden van de hoefdieren verder vergroot kunnen worden en de genetische uitwisselingsmogelijkheden verbeterd door aansluiting van leefgebieden met andere populaties. 


\subsection{Draagkracht}

Ecologische draagkracht wordt vaak gedefinieerd als de maximale grootte van een populatie op basis van het natuurlijke voedselaanbod. Een andere benadering gaat uit van hoeveel dieren er kunnen lopen om een 'gewenst ecosysteem functioneren' in stand te houden. De draagkracht van een gebied hangt primair samen met de omvang en kwaliteit van het leefgebied voor de soort (Groot Bruinderink et al., 1999). Zo is de draagkracht van een voedselrijk gebied hoger dan die van een voedselarm gebied van vergelijkbare grootte. Hoeveel dieren er uiteindelijk voorkomen, wordt bepaald door limiterende en regulerende processen. Limitering betreft elk proces dat een kwantitatief effect heeft op de populatiegroei; limiterende factoren zijn verantwoordelijk voor veranderingen van jaar tot jaar en zorgen dus voor schommelingen in de dichtheid (Messier, 1991). Ze zijn meestal stochastisch van aard, maar kunnen ook dichtheidsafhankelijk zijn. Regulering betreft elk dichtheidsafhankelijk proces dat uiteindelijk de populatie binnen een bepaalde range houdt; regulerende factoren zijn dus een subset van limiterende factoren gekarakteriseerd door negatieve feedbackmechanismen die de populatiegroei beperken als de dichtheid toeneemt (zie ook paragraaf 4.1). De draagkracht wordt dus bepaald door factoren als (1) de aanwezigheid van predatoren, (2) de aanwezigheid van parasieten en ziekteverwekkers, (3) de aanwezigheid van andere (grote) herbivoren - zoals andere soorten hoefdieren - die concurreren om voedsel en ruimte of faciliteren, of (4) het weer (neerslag, temperatuur, sneeuwdikte) (Kramer et al., 2017; Groot Bruinderink et al., 1999; zie ook paragraaf 3.1). Onder natuurlijke omstandigheden - dus zonder populatiebeheer - fluctueert de draagkracht (en daarmee de populatiegrootte) in de tijd en kan deze hoger liggen in gunstige jaren en weer terug zakken als er bijvoorbeeld een strenge winter volgt (zie Figuur 13).

Bij proactief beheer, zoals op de Veluwe, wordt door de FBE bepaald wat de stand of dichtheid zou moeten zijn. Deze wordt dan door afschot van gezonde dieren bereikt, vaak onafhankelijk van bijvoorbeeld variatie in de voedselsituatie tussen jaren. Hierbij wordt een vaste stand nagestreefd, waarbij de dichtheid aan dieren zo laag is dat concurrentie binnen en tussen soorten geen rol speelt. Dat 'maakt' een ecologisch heel ander ecosysteem en leidt tot heel andere ecologische processen. Proactief beheer middels jacht kan niet gelijk worden gesteld aan predatie, dus aan top-downregulatie. Het verschil is dat bij fluctuaties van de dichtheid van prooien ook predatoren mee fluctueren met hun voedsel. Als er veel voedsel is, bijvoorbeeld door zachte winters, gaat het beter met de prooidieren, waardoor er meer predatoren komen die dan een sterker effect hebben op de prooidieren. Proactief afschot verschilt hiervan doordat het aantal te doden dieren afhankelijk is van de trend. Is de stand hoog, dan worden er meer geschoten. Ook is het belangrijk dat jacht selectief gericht is op de grootste soorten, terwijl in natuurlijke systemen juist de kleinere soorten relatief de meeste predatie zullen ondervinden. In natuurlijke systemen zijn grotere herbivoren vaak door voedsel gelimiteerd, terwijl kleinere herbivoren door predatie zijn gelimiteerd (Hopcraft et al., 2010).

Voor de Veluwe betekent dit dat er variatie is in draagkracht tussen de voedselrijkere delen van het gebied en de voedselarmere delen: op de voedselrijkere delen vinden hoefdieren meer eten dan op de armere delen. Dichtheden van damherten en edelherten op basis van het natuurlijke voedselaanbod kunnen naar verwachting op de Veluwe per soort gaan fluctueren rondom de ca. 20 dieren per 100 ha (Groot Bruinderink et al., 2004; Huysentruyt \& Casaer 2015; zie paragraaf 6.1). Fluctuaties van wilde zwijnen zullen groot zijn, afhankelijk van het aanbod van mast van eik en beuk, waarbij periodiek hoge dichtheden bereikt kunnen worden van ca. 10-15 dieren per 100 ha (Groot Bruinderink et al. 2009). Bij deze hogere dichtheden zal niet alleen de concurrentie tussen hoefdieren toenemen, maar ook de graasdruk op de vegetatie. De vegetatiesamenstelling en -structuur zullen vervolgens veranderen als gevolg van de hoge graasdruk. Onderlinge concurrentie tussen hoefdieren kan er ook toe leiden dat de gevoeligste soorten (als het ree) worden verdrongen. 


\subsection{Vaststellen van aantallen}

Er zijn verschillende methodes ontwikkeld om dichtheden of aantallen van grote hoefdieren te schatten (Groot-Bruinderink et al., 2009; zie Tabel 3). Er kunnen directe en indirecte observaties worden gedaan, al dan niet met gebruik van een scala aan hulpmiddelen als verrekijker en/of telescoop, schijnwerpers, verschillende typen camera's, restlichtversterkers en warmtebeelden. Methoden waarbij een schatting kan worden gemaakt van het deel van de populatie dat niet wordt gezien, kunnen efficiënt zijn in termen van geïnvesteerde tijd. Denk daarbij aan de vangst-merk-terugvangst (terugzien) methode (capture-mark-recapture respectievelijk resighting), de catch-per-unit effort (CPUE) of de lijn-transect-methode. Zichtwaarnemingen vanaf de grond zijn het meest ingeburgerd. Over het algemeen wordt aangenomen dat deze methode een onderschatting oplevert van de werkelijke populatie (Groot-Bruinderink et al., 2013a). Zichtwaarnemingen vanuit de lucht zijn goed te gebruiken voor het schatten van de populatieomvang en het vaststellen van een index, maar geven een minder nauwkeurig beeld van de geslachts- en leeftijdsopbouw van een populatie, met name in gebieden met veel dekking zoals de Veluwe.

Tabel 3 Waarderingen van een aantal directe en indirecte methoden om hoefdieren te inventariseren. Scores: + = goed; \pm = twijfelachtig; - = slecht. Afkortingen in de tabel: IR = infra rood, CMR = capture-mark-recapture, CPUE = catch-per-unit effort. Overgenomen uit Groot Bruinderink et al. (2009).

\begin{tabular}{l|l|l|l|l}
\hline Methode & betrouwbaar & nauwkeurig & kosten & $\begin{array}{l}\text { toepasbaarheid wild } \\
\text { zwijn }\end{array}$ \\
\hline Direct & & & & \\
\hline Zicht_land & + & - & + & + \\
\hline Zicht_lucht & + & - & \pm tot + & - \\
\hline IR_lucht & + & \pm & \pm tot + & - tot \pm \\
\hline IR_land & + & \pm & + & - tot \pm \\
\hline CMR & \pm & + & - & \pm \\
\hline CPUE & \pm & + & - & \pm \\
\hline Distance & \pm & + & - & \pm \\
\hline Indirect & & & & \\
\hline Keuteltellingen & \pm & \pm & \pm & \pm
\end{tabular}

\subsubsection{Zichtwaarnemingen}

De in Nederland meest gangbare telmethodes zijn gebaseerd op zichtwaarnemingen. Hierbij worden elk jaar rond eind maart/begin april drie opeenvolgende tellingen uitgevoerd (avond, ochtend, avond) gedurende circa twee uur rond zonsopkomst en zonsondergang, soms met gebruik van lokvoer. Waarnemingen worden gedaan vanuit vaste of mobiele posten en soms worden delen van een gebied letterlijk uitgekamd. De uitkomst wordt vaak uitgedrukt in het MNA, Minimum Number Alive. Maar ook worden de resultaten van de drie telronden gebruikt als drie onafhankelijke schattingen van de minimumpopulatie waaruit een gemiddelde en een betrouwbaarheidsinterval worden berekend. De methode geldt als arbitrair en onnauwkeurig, met als hoogst haalbare product een trend (index) in de aantallen over de jaren (Groot-Bruinderink et al., 2013a). Voor de Veluwe bleek de meetfout in de tellingen dusdanig groot dat het niet mogelijk was om de aantallen zwijnen te bepalen en werden de aantallen edelhert onderschat (Groot Bruinderink et al., 2013a). Van Os (2018) vergeleek zichtwaarnemingen met gegevens uit de jachtboeken van het Nationale Park De Hoge Veluwe en concludeerde dat aldaar de tellingen een adequate weergave van aantallen edelherten en moeflons opleverde, maar dat tellingen voor wild zwijn de populatiegrootte sterk onderschatte.

Belangrijke aandachtspunten zijn het risico van dubbeltellingen, het aantal dieren dat wordt gemist en de betrouwbaarheid in de zin van het zo veel mogelijk constant houden van variabelen over de jaren. Bij het wild zwijn vormt de na-aanwas een probleem: de biggen die na de telling worden geboren. Dit wordt versterkt doordat onder gunstige omstandigheden zeugen meerdere worpen kunnen hebben en 
biggen uit een vroege worp in het najaar alweer bevrucht kunnen worden. De dynamiek is dan ook veel grilliger dan bijvoorbeeld bij edelherten, waarvan de hindes gemiddeld 1 kalf per jaar hebben en de populatieontwikkeling relatief goed te voorzien is.

Door enkele hoefdieren met een zender uit te rusten (gps-logger) kan inzicht verkregen worden in het dagpatroon (wanneer zijn ze actief, wanneer rusten ze), actieradius (hoe ver gaan ze), terreingebruik (waar rusten ze en waar foerageren ze, voorkeur voor voedselgewas etc.). In combinatie met zichtwaarnemingen kan dit voor de extrapolatie nuttig zijn om tot degelijkere aantalsschattingen en dichtheden te komen.

\subsubsection{Cameravallen}

Een relatief nieuwe methode om het terreingebruik en de talrijkheid van dieren te meten, zijn netwerken van wildcamera's die alle dieren fotograferen die binnen het bereik van een warmtesensor komen. Door wildcamera's op meerdere willekeurige locaties te plaatsen, kan de gemiddelde gebruiksintensiteit van habitats worden gemeten, bijvoorbeeld de vraatdruk of de beschikbaarheid van gastheren voor teken (Hofmeester et al., 2017; Ramirez, 2019). Het is zelfs mogelijk de populatiedichtheid te schatten door de gemeten gebruiksintensiteit te combineren met gegevens over de detectiekansen en de gemiddelde afstand die dieren op een dag afleggen (Rowcliffe et al., 2008; 2014). Cameranetwerken hebben als groot voordeel dat de dieren tijdens de waarneming niet worden verstoord en dat systematisch, op lokaal niveau informatie wordt verkregen over welke dieren waar actief zijn. Een nadeel is de bewerkelijkheid van de verwerking van het vele fotomateriaal. Wageningen Universiteit experimenteert op dit moment met wildcamera's voor het schatten van wilddichtheden in het Nationale Park De Hoge Veluwe. De (letterlijk) miljoenen foto's worden verwerkt door inzet van het grote publiek in een citizen-science project (snapshot) en door automatische beeldherkenning.

\subsubsection{Keuteltellingen}

Door keutels te zoeken, kan een indicatie worden verkregen van de aanwezige soorten hoefdieren op een locatie. Het is echter niet mogelijk om uit het aantal keutels de aanwezige aantallen te herleiden. Relevante factoren daarbij zijn defecatiesnelheden en afbraaksnelheden van keutels. De dichtheden van keutels geven wel een indruk van de gebruiksintensiteit van een specifieke locatie, zeker als tellingen regelmatig herhaald worden.

\subsubsection{Genetische technieken}

Het gebruik van genetische technieken kan mogelijk wel inzicht in de werkelijke aantallen geven. Tevens levert deze methode inzicht in migratie- en dispersiegedrag. Deze methode wordt nu al toegepast bij de monitoring van de otter en wolf in Nederland, maar kan mogelijk ook voor hoefdieren worden toegepast. Voorwaarden zijn dat de genetische variatie voldoende groot is, zodat elk individu genetisch een uniek profiel heeft (de populatie mag niet te ver ingeteeld en dus genetisch verarmd zijn) en dat er op een gedegen manier keutels verzameld worden, zodat (vrijwel) alle aanwezige dieren in een onderzoeksgebied 'gevangen' worden en dus een betrouwbare inschatting van de aantallen en geslachten verkregen wordt. De genetische variatie van hoefdieren in Nederland blijkt voldoende groot voor individuele identificatie (De Groot et al. 2016). Indien de methode herhaaldelijk wordt uitgevoerd, kan ook de dynamiek inzichtelijk worden (zoals overleving, migratie). Vooralsnog lijkt deze methode erg intensief en kostbaar voor het schatten van populatiegroottes. Op dit moment wordt onderzoek gedaan naar deze methode voor wild zwijn.

\subsubsection{Drones \& thermocamera's}

Mogelijk dat drones uitgerust met een gevoelige thermische camera kunnen worden ingezet om nauwkeurige tellingen te maken van het aantal grote hoefdieren in een gebied. Daarbij moet nog worden getest of toepassing in de natuur mogelijk is om met minimale verstoring een compleet beeld van de aanwezige grote dieren te verkrijgen. Op dit moment zijn hier experimenten mee gaande, onder andere in de Amsterdamse Waterleidingduinen (L. Kuiters, pers. med.). 


\subsubsection{Monitoring van wilddruk}

Momenteel is er geen methode beschikbaar die in staat is om de exacte aantallen van hoefdieren, en tevens de effectiviteit van beheer op het reguleren van hoefdierpopulaties, voldoende accuraat te bepalen (maar zie Van Os, 2018). Technologische ontwikkelingen (zie voorgaande) maken het steeds makkelijker om aanvullende waarnemingen te doen waarmee de betrouwbaarheid van de aantalsschattingen verhoogd zou kunnen worden en waarmee tevens meer inzicht kan worden verkregen over terreingebruik en actieradius. Door de onzekerheid over werkelijke standen, dynamiek en de variatie in terreingebruik, is het bepalen van een benodigde beheerinspanning op basis van telgegevens lastig te onderbouwen. Ontwikkelingen in populatiemodellering kunnen weliswaar meer precisie en accuratesse realiseren in geschatte aantallen op het niveau van het leefgebied (zie o.a. Groot Bruinderink et al., 2013a), maar wanneer wildbeheer, in ieder geval lokaal, in dienst staat van ontwikkelingen in de vegetatiestructuur en aanwezige flora en fauna, zijn aantalsschattingen op leefgebied weinig bruikbaar. In dat geval kan aantalsregulatie (wilddruk) ook lokaal worden gestuurd via de waarneembare effecten van grote hoefdieren op de structuurkenmerken, vegetatietypen en (bijzondere) kwaliteitssoorten of typische plant- en diersoorten van de habitattypen (zie hoofdstuk 5). Gedeputeerde Staten Gelderland (2019) voorzien reeds een dergelijk monitoringsysteem ten aanzien van natuurdoelen, wellicht in combinatie met het monitoren van effecten op bosbouw. Tellingen blijven dan nog steeds waardevol om op leefgebiedniveau de trends in aantallen, geslachtsverhoudingen et cetera te blijven volgen. 


\section{Indicatoren voor wilddruk}

\section{$5.1 \quad$ Vegetatiestructuur}

De bosstructuur wordt sterk bepaald door de ruimtelijke verdeling van de verschillende bosontwikkelingsfasen en de schaal waarop deze aanwezig zijn. Als gevolg van verstoringen treedt verjonging van bomen vaak op in cohorten van min of meer gelijktijdig gevestigde bomen. Deze vestigen zich in opengevallen ruimtes (na kap of windworp) of onder scherm na het wegvallen van individuele bomen (als gevolg van kap, storm, ziekte of aantasting). In de jonge fase is een dergelijke verjonging kwetsbaar voor grote herbivoren en een hoge wilddruk kan het ontstaan van een struiklaag zelfs geheel tegenhouden. Hierdoor blijft de onderlaag van het bos open en zal met het verstrijken van de tijd en ontbreken van verjonging een bos in de boomfase overblijven met een steeds ijler kronendak. Bij een aandeel naaldhout in de verjonging zal meestal wel een struiklaag kunnen ontstaan, gedomineerd door naaldbomen.

Niet alle bosontwikkelingsfasen bieden plaats voor verjonging. De vestiging van nieuwe cohorten kan alleen plaatsvinden bij voldoende lichtrijke omstandigheden. Dat betekent dat wanneer een cohort in sluiting komt (dichte fase) en opgroeit tot de stakenfase en jonge boomfase, het lichtniveau ontoereikend is voor succesvolle vestiging. Dit geldt voor cohorten van alle boomsoorten. Pas in de boomfase kan onder het kronendak weer voldoende licht toetreden voor nieuwe verjonging. Dit moment varieert per boomsoort: het ligt relatief vroeg voor bomen met transparante kronen (den, berk, eik, lariks). Cohorten met schaduw verdragende boomsoorten als douglas en beuk kunnen zeer lang te donker blijven voor de vestiging van nieuwe generaties bomen.

Voor de biodiversiteit in boshabitats is dood hout van cruciaal belang: zo'n 50\% van de fauna in bossen is afhankelijk van dood hout (Siepel, 1992). Grote herbivoren hebben waarschijnlijk een verwaarloosbaar effect op het ontstaan en voorkomen van dood hout. Wild zwijn kan wel de fysieke afbraak van dood hout versnellen op zoek naar insecten (Figuur 14).

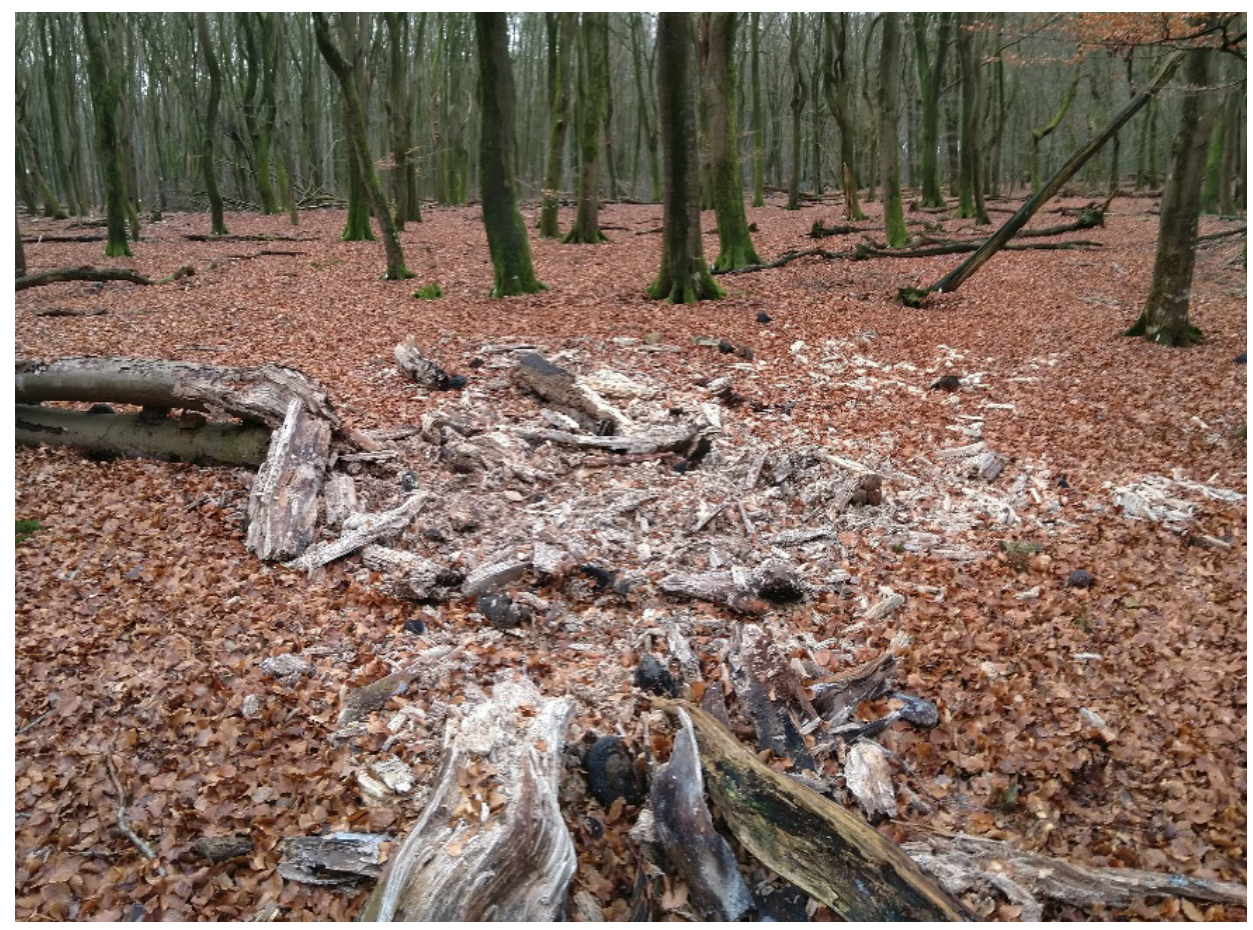

Figuur 14 Een boomlijk van een beuk in het bosreservaat Pijpebrandje, volledig uiteengetrokken door voedselzoekende wilde zwijnen. 
Al met al zal bij een hoge wilddruk de vorming van een struiklaag worden belemmerd of zelfs geheel worden voorkomen. In bossen waarin de lichtbeschikbaarheid voldoende is voor het ontstaan van een struiklaag is het ontbreken daarvan meestal een teken van een hoge wilddruk. Dit gaat dan vaak ook gepaard met een lage kruidlaag. Grassen en dwergstruiken tonen dan ook de sporen van vraat van hoefdieren. In Ontario (Canada) kon de populatiedichtheid van witstaartherten worden geschat door de gemiddelde hoogtes te meten van Trillium grandiflorum. Hoe meer herten, hoe lager deze soort (Koh et al., 2010). Witstaartherten eten vooral de hogere planten, die daardoor minder in bloei komen. Dit kon zelfs worden gebruikt als indicator voor een gewenste wildstand: op basis van deze relatie adviseerde Anderson (1994) voor de staat Illinois (VS) een maximumdichtheid van 4-6 herten per $\mathrm{km}^{2}$.

\subsection{Vraatpercentages}

Hertachtigen vreten aan bomen en het is niet meer dan logisch dat een hogere dichtheid leidt tot meer vraat. Dit is in een veelvoud aan studies aangetoond (zie o.a. Gill \& Morgan, 2010; Royo et al., 2016, 2017; Blossey et al., 2019). Chevrier et al. (2012) onderzochten bijvoorbeeld de relatie tussen aantallen reeën en de mate van vraat aan eikenzaailingen in een bosgebied in noordoost Frankrijk. De lokale dichtheid van de reeënpopulaties werd in opeenvolgende jaren vastgesteld door markrecapture-technieken, de vraatindex werd direct berekend uit het percentage eikenzaailingen $(<120 \mathrm{~cm})$ dat was aangevreten. Bij een verdubbeling van het aantal reeën in het gebied (van 180 naar 360 in een omrasterd gebied van 1360 ha) steeg de vraatindex lineair van 5 naar 18\%. Frerker et al. (2013) keken naar vraatpercentages in een drietal parken rond het Grote merengebied in NoordAmerika. Ook zij lieten zien dat een toename van hertachtigen (eland en witstaartherten) leidt tot een toename van vraat aan bomen. In studies naar ree in Frankrijk werd een directe relatie gevonden tussen de populatiegrootte van ree en de vraat aan bomen (Morellet et al., 2007, Maublanc et al., 2016).

De geconstateerde vraatpercentages mogen echter niet direct worden vertaald naar een verwachting over de overleving van soorten en de mate waarin die soorten kunnen doorgroeien naar een hoogteklasse waarin zij niet meer belemmerd kunnen worden in hun groei door vraat. Dit hangt af van de mate waarin boomsoorten in staat zijn de verloren takken en bladeren te vervangen met nieuwe scheuten (compenserende groei) en het relatieve hoogteverlies ten opzichte van omringende boomsoorten. In het Schweizerische Nationalpark (Zwitserland) nam het aandeel van de minst aangevreten boomsoort, de bergden (Pinus montana), bij een toenemend aantal edelherten af ten opzichte van de sterk aangevreten fijnspar en arve (Pinus cembra) (Schütz, 2005).

Verder zien we dat in het vraatmonitoringsysteem in Beieren, waarin lokaal wordt vastgesteld of er sprake is van een te hoge wilddruk of niet, de verdeling van de vraatpercentages aan de verjonging een zeer grote overlap vertoont tussen beide situaties (Figuur 15). Bij vraatpercentages van grofweg 5-30\% kan zowel sprake zijn van een aanvaardbare als onaanvaardbaar hoge wilddruk.

Beide voorbeelden laten zien dat alleen het vaststellen van een vraatpercentage aan bomen onvoldoende informatie biedt over de werkelijke verjongingsmogelijkheden van bomen. 


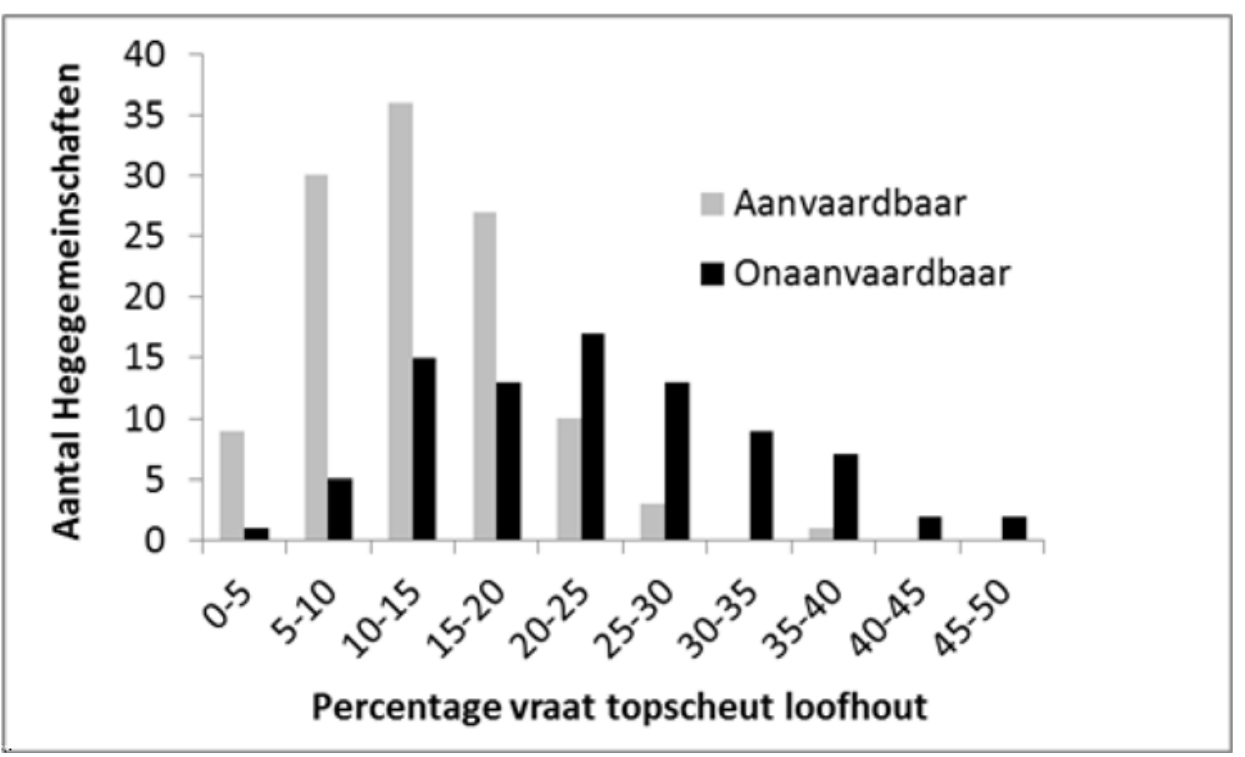

Figuur 15 De verdeling van de percentages topvraat aan loofbomen, uitgesplitst over de Hegegemeinschaften in Beieren, waarin de wilddruk als aanvaardbaar of onaanvaardbaar werd beoordeeld (selectie van eerste 200 gerapporteerde Hegegemeinschaften). Figuur overgenomen uit Den Ouden et al., 2016.

\subsection{Aanwezigheid soorten}

Door de selectiviteit in vraat worden gewilde soorten veel sterker gestoord in hun ontwikkeling dan vermeden soorten. In de vegetatie kunnen gewilde soorten nog wel een tijdje overleven als laag en sterk aangevreten struikje, maar uiteindelijk leidt een hoge vraatdruk tot een verminderd voorkomen van soorten en een lagere diversiteit. Tegelijkertijd gaat de vraat zich richten op de overgebleven soorten en kunnen door de hogere lichtbeschikbaarheid meer plantensoorten zich handhaven (Nessing \& Zerbe, 2002; Frerker et al., 2013).

Door de verschuivingen in voorkomen van soorten onder vraatdruk kan worden gezocht naar soorten die toenemen onder hoge graasdruk, of juist soorten die verdwijnen bij een bepaalde mate van graasdruk. In Noord-Amerika lieten Frerker et al. (2013) zien dat bij een hoge graasdruk van witstaartherten het aandeel van Bosgierstgras (Millium effusum) en Hennepnetel (Galeopsis tetrahit) toenam. Zij benadrukken dat indicatoren uit de ondergroei sterk groeiplaatsgebonden zijn, waardoor het ruimtelijke bereik van een dergelijke methode beperkt is.

In Noordwest-Europa is door verschillende auteurs gekeken naar het voorkomen van specifieke soorten in de ondergroei in relatie tot dichtheden van grote herbivoren (zie o.a. Gill \& Beardall, 2001). Een interessante soort is wat dit betreft de braam. Diverse onderzoeken lieten zien dat er een directe relatie is tussen het voorkomen van braam en de populatiegrootte van ree (Gill, 1994; Maublanc et al., 2016; Morellet et al., 2001). Een hoge populatiedichtheid van ree leidt dan tot een sterke afname van braam in de ondergroei.

De wilde lijsterbes is in dit kader een interessante soort. De bessen worden zeer effectief verbreid, vooral door vogels, zodat geschikte plekken voor kieming en vestiging makkelijk bereikt kunnen worden. Bovendien is de wilde lijsterbes uitstekend in staat zich te vestigen in relatief schaduwrijke bossen. De wilde lijsterbes komt over de gehele Veluwe voor, maar het voorkomen in de struiklaag is direct afhankelijk van de vraatdruk: bij toenemende dichtheden van grote herbivoren is wilde lijsterbes als een van de meest geprefereerde boomsoorten niet in staat door de vraatgrens heen te groeien (Nessing \& Zerbe, 2002). Op de Veluwe zijn er gebieden waarin de wilde lijsterbes duidelijk minder in de struiklaag voorkomt dan elders (Figuur 16). 


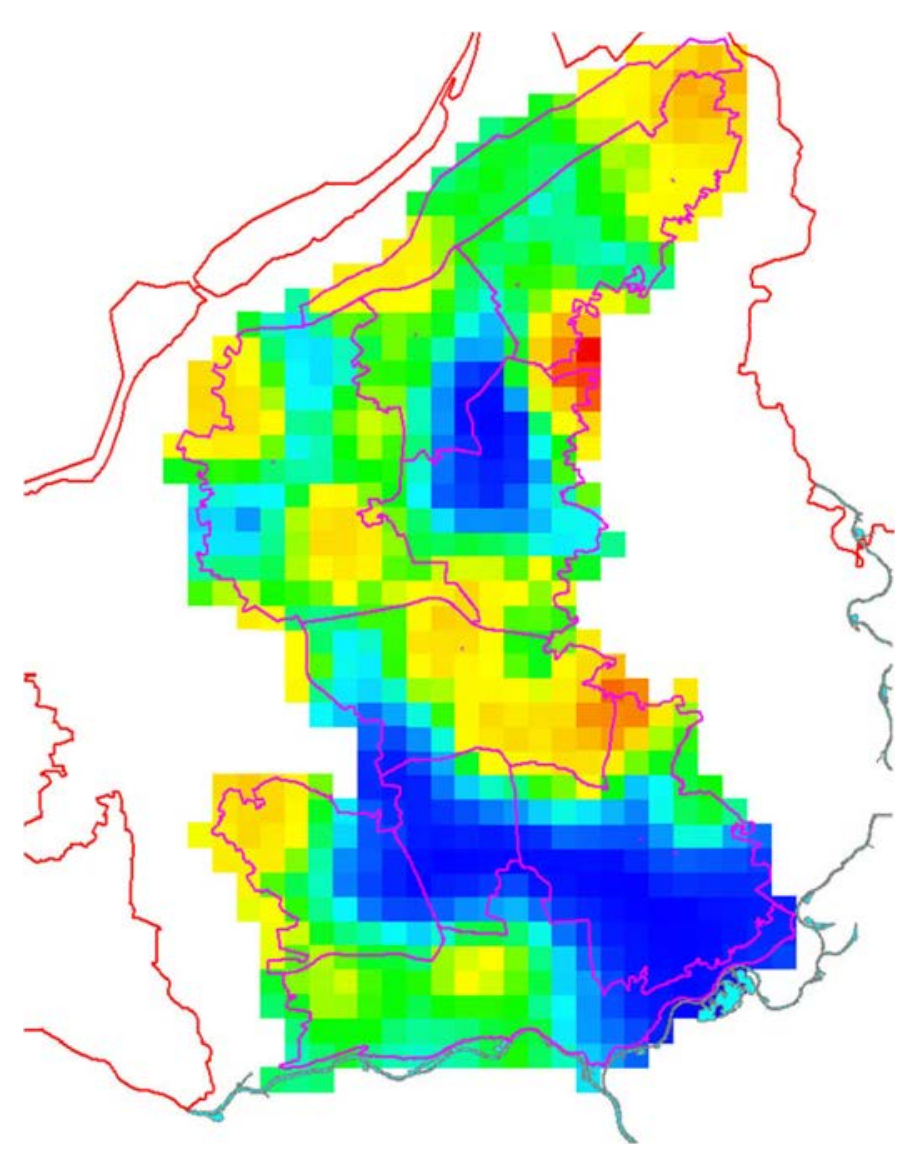

Figuur 16 Het voorkomen van wilde lijsterbes op de Veluwe, op basis van data over de samenstelling van de struiklaag in de Nationale Bosinventarisatie en SyHI/Woodstock in cirkelvormige plots met een straal van $5 \mathrm{~m}$ (Den Ouden et al., 2016). Legenda: aantallen wilde lijsterbessen per cirkel: blauw $=0$, lichtblauw $=1$, groen $=2$, geel=4, oranje/rood =meer dan 4 .

De wilde lijsterbes is als sterk geprefereerde soort als de spreekwoordelijke kanarie in de kolenmijn: als wilde lijsterbes zich kan vestigen in de struiklaag $>2 \mathrm{~m}$ en mee kan groeien met de andere aanwezige soorten, dan is de vraatdruk laag genoeg om de meeste loofboomsoorten in de verjonging onbelemmerd tot in de struiklaag te laten doorgroeien. Het is niet bekend bij welke dichtheid aan herbivoren sprake is van onbelemmerde doorgroei van wilde lijsterbes (zie paragraaf 3.5).

Bij het gebruik van wilde lijsterbes als indicator is het onzeker hoe de preferentie voor deze soort gaat verschuiven als ook andere loofboomsoorten worden geïntroduceerd in een habitat. Mogelijk worden bepaalde soorten sterker geprefereerd, waardoor deze wel belemmerd worden in de groei, terwijl wilde lijsterbes kan doorgroeien. Nader onderzoek moet dit verder uitwijzen. Onder dit voorbehoud lijkt de wilde lijsterbes nu Veluwebreed de geschiktste soort om als indicator voor een lage vraatdruk te dienen (Figuur 17). 


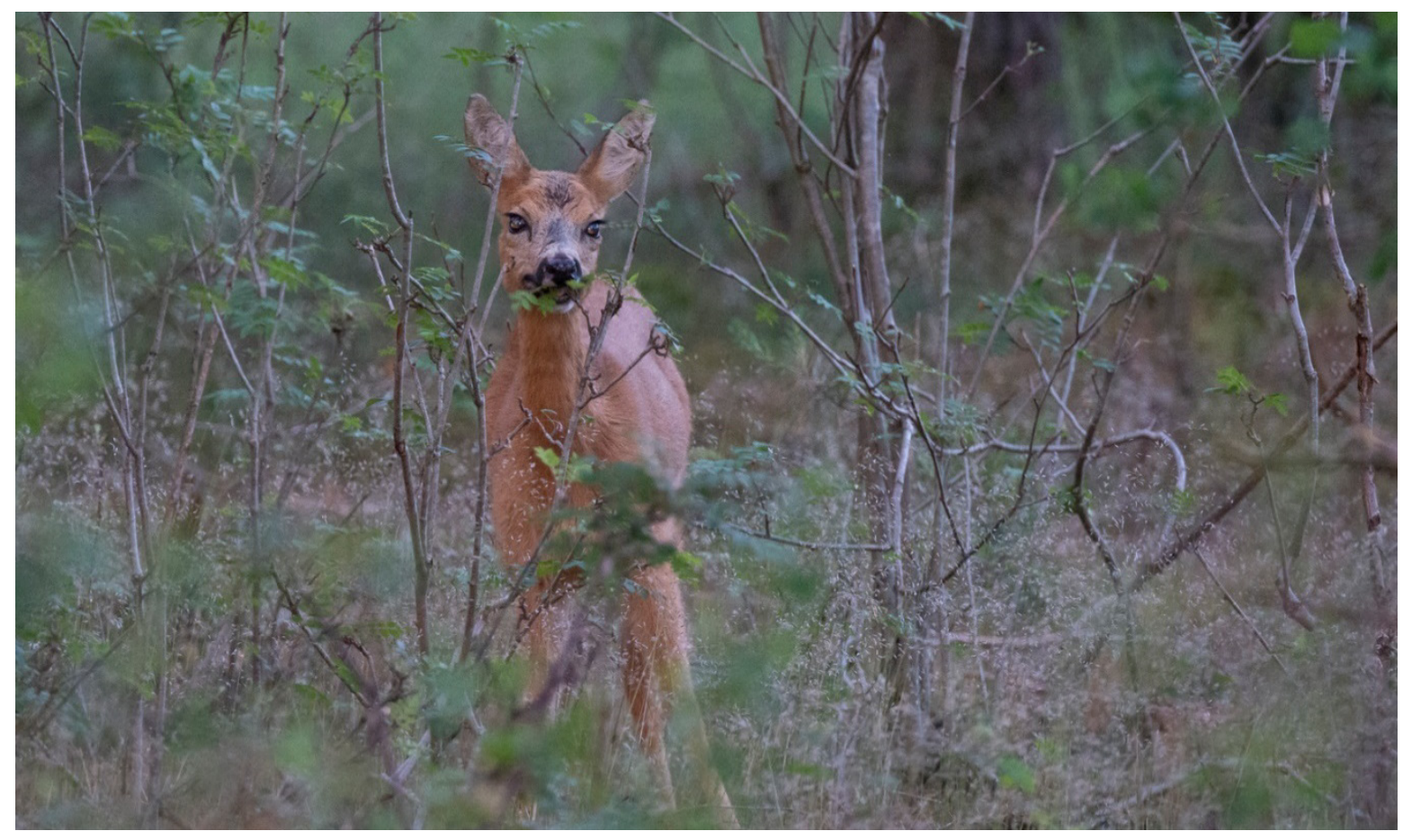

Figuur 17 Een ree vretend van wilde lijsterbes. Door de sterke voorkeur van ree (en edelhert) voor wilde lijsterbes, en zijn wijdverspreide voorkomen, is deze soort een geschikte indicator voor de mate van vraatdruk in een gebied.

\section{$5.4 \quad$ Vraatgrens}

Grote herbivoren eten ook knoppen en bladeren van takken aan grotere bomen. Langs bosranden kunnen bomen tot op de grond betakt blijven en een kroon handhaven, maar door vraat verdwijnt de onderkant van de kroon tot op de maximale reikhoogte van de betreffende diersoort (ree $\pm 1,5 \mathrm{~m}$, edelhert $\pm 2 \mathrm{~m}$ ). Bij een hoge vraatdruk verdwijnt de onderkant van de kroon, waardoor een rechte onderkant ontstaat en men onbelemmerd de rest van het bos in kijkt. We hebben geen informatie gevonden die wilddichtheid koppelt aan het voorkomen van een vraatgrens, maar aangenomen kan worden dat een vraatgrens pas ontstaat bij een relatief matige tot hoge vraatdruk.

\subsection{Struikvorm}

Doordat hertachtigen bladeren en knoppen van het gehele bereikbare deel van de plant eten, kan daardoor de vorm van de plant veranderen. Door topvraat wordt de lengtegroei van de boom afgeremd en de groei van zijtakken gestimuleerd (Kuiters et al., 1997). Regelmatig knopverlies leidt tot sterker vertakte bomen en bij intensieve vraat kunnen bomen een bonsai-uiterlijk vertonen (Figuur 18). Wanneer scheuten binnen een sterk aangevreten plant boven de vraatgrens uit groeien, ontstaat daaruit weer een regelmatig vertakte boom. Dit leidt in eerste instantie tot een zandlopervorm. Deze typische boomvormen zijn gerelateerd aan een hoge graasdruk en vinden we vooral bij schaduwtolerante soorten met een sterk compenserend vermogen na knopverlies, zoals hulst en beuk. In lichte situaties, zoals zeer open dennenbossen en heidevelden, kan ook eik breed uitstoelende struiken vormen onder hoge graasdruk (Den Ouden \& Spek, 2007, Figuur 18).

Uit de aanwezigheid van deze typische struikvormen kan in principe worden afgeleid dat er ter plekke frequente en over een lange periode hoge vraatdruk heerst. Het is echter niet bekend in hoeverre dit ook indicatief is voor een bepaalde algemene vraatdruk op de vegetatie ter plekke. Het kan immers ook zijn dat betreffende individuen een zekere intrinsieke aantrekkingskracht uitoefenen op grazers, bijvoorbeeld als gevolg van verschillen in nutriëntenconcentraties of inhoud aan antivraatstoffen (Burney \& Jacobs, 2013). In het geval van een (overigens) dominante verjonging van onsmakelijke 
naaldbomen, zal ook een enkel opgeslagen loofboom een relatief grote aantrekkingskracht uitoefenen op hoefdieren, en dus ook bij een lage wildstand vaak worden aangevreten.

Onderzoek uit Brits Columbia (Martin et al., 2011) liet zien dat de vorm van de struikvormende soort Holodiscus discolor sterk gecorreleerd was aan vraatdruk. Bij een hoge graasdruk waren de struiken duidelijk afgeplat en hadden meer dode of dunne scheuten. Dit ging gepaard met sterk verhoogde vraatpercentages van de individuen. De bruikbaarheid van struikvorm als indicator voor wilddruk werd bevestigd door Arcese et al. (2014). Als deze resultaten mogen worden vertaald naar de Veluwe, kan worden aangenomen dat de aanwezigheid van bonsai-, zandloper- of breed uitstoelende struikvormen op de Veluwe een indicatie is voor een hoge graasdruk. Het is niet bekend vanaf welke dichtheden deze fenomenen optreden.
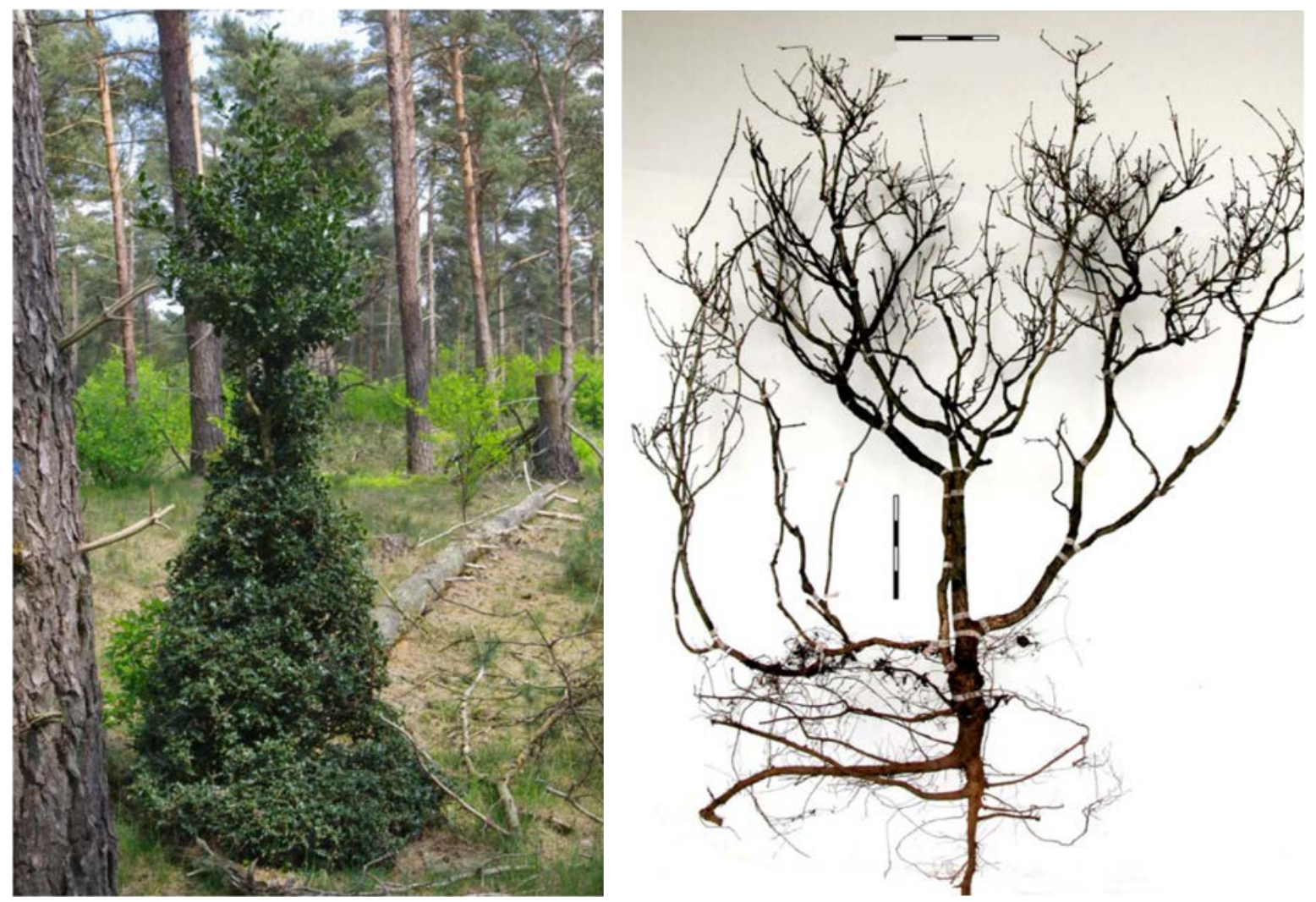

Figuur 18 Een hoge graasdruk leidt tot het ontstaan van typische boomvormen. Links een hulst in het Nationale Park De Hoge Veluwe met een duidelijke zandlopervorm, rechts een langdurig begraasde (>35 jaar) zomereik uit heide in Nationaal Park Veluwezoom (schaalaanduiding per $5 \mathrm{~cm}$ ).

\subsection{Bodemverstoring}

De mate en frequentie van wroeten door zwijnen neemt toe naarmate de populatiedichtheden toenemen. Het optreden van wroetactiviteit is verder afhankelijk van het bostype en de hoeveelheid beschikbare alternatieve voedselbronnen (Figuur 19). Daarnaast is wroetactiviteit afhankelijk van de hoeveelheid mast: bij veel aanbod aan eikels gaan zwijnen op zoek naar dierlijk eiwit om de tannines in eikels te neutraliseren. Er is echter nauwelijks iets bekend over de relatie tussen de hoeveelheid wroeten en effecten op biodiversiteit, dus ook niet over de specifieke kenmerken van het wroeten waarbij sprake is van een substantieel negatief effect. Het vermoeden bestaat dat de impact groot kan zijn, vooral in Oude eikenbossen. Er is meer onderzoek nodig om wroetsporen nader te categoriseren om als indicator te kunnen dienen. Daarbij kan de nadruk liggen op specifieke eigenschappen van bodemopbouw en humuskarakteristieke (Groot Bruinderink et al., 2009). 


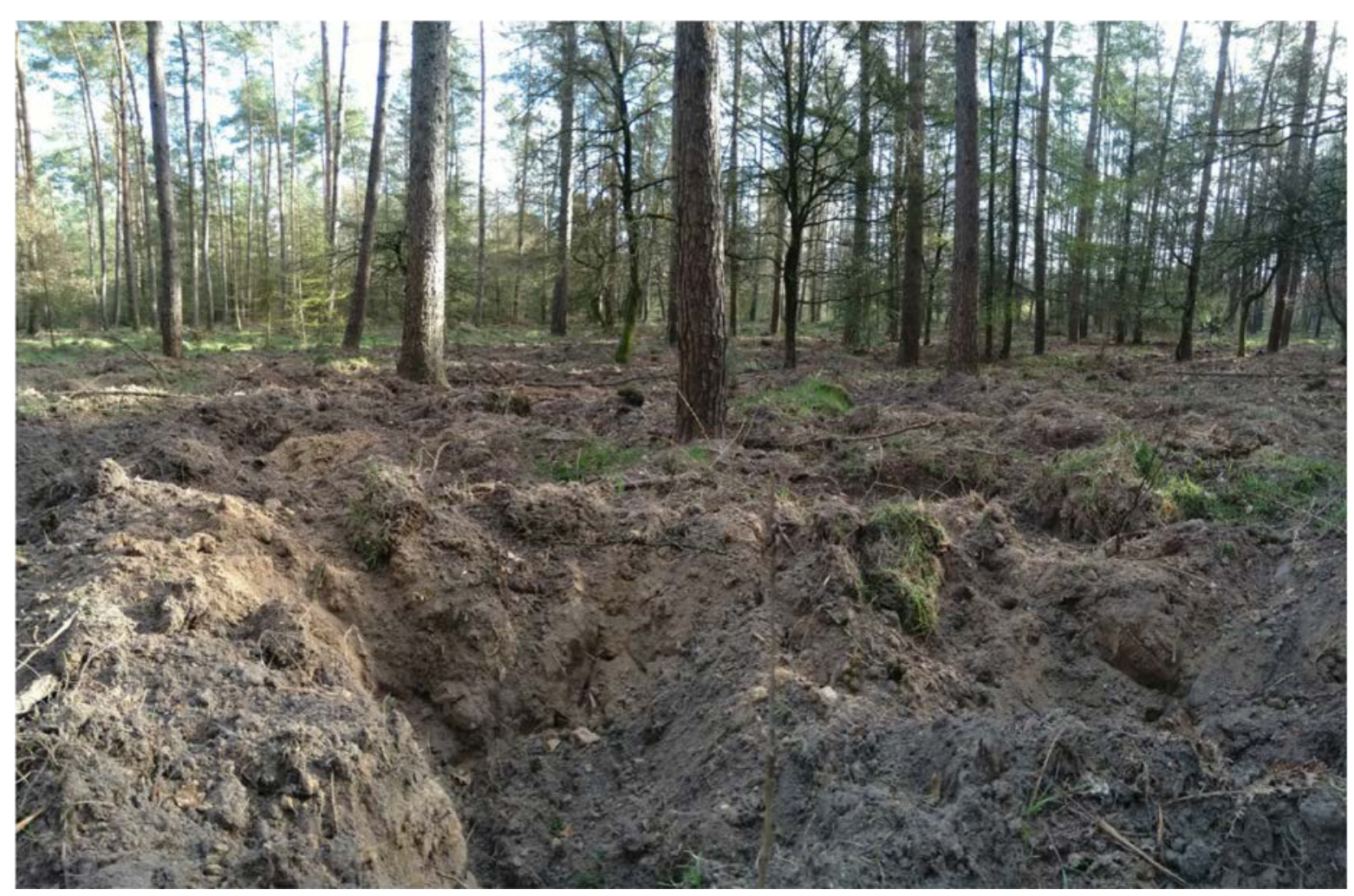

Figuur 19 Zeer grootschalige en diepe bodemverstoring in een lariksbos in het Speulderbos. De hoge zwijnenstand leidt hier tot volledige omzetting van de toplaag van de bodem. Dit fenomeen neemt de laatste jaren sterk toe en de bodem in de meeste lariks-, douglas- en eikenbossen worden nu jaarlijks volledig omgeploegd. 


\section{Scenario's}

In het Beheerplan Natura 2000 Veluwe wordt op een aantal plaatsen het voorkomen van vraatschade door grote hoefdieren bepleit door het beschermen van kwetsbare vegetatie met behulp van rasters. Dit is de enige genoemde maatregel in het kader van wildbeheer. Er is een relatie tussen hoefdieraantallen en begrazingsdruk, verkeersrisico's et cetera, maar die is niet (per se) lineair (zie Brouwers, 2004; Wubben, 2005; Van Dongen, 2005; Ramirez et al., 2018). Onderstaande tekst analyseert een aantal mogelijke scenario's en de consequenties daarvan op populatiegrootte, terreingebruik en vraateffecten van grote hoefdieren. Voor elk scenario wordt de vraag beantwoord in hoeverre met de verwachte ontwikkelingen in wilddruk binnen betreffend scenario de gewenste kwaliteitsverbetering en uitbreiding van het boshabitattype kunnen worden bereikt. Ook hier ligt de nadruk op hertachtigen, met name edelhert, en wild zwijn. We gaan daarbij nadrukkelijk uit van de huidige context op de Veluwe, met speciale aandacht voor ruimtegebruik van grote hoefdieren. Mogelijke grootschalige toekomstige ontwikkelingen zoals klimaatverandering laten we hier buiten beschouwing.

\subsection{Autonome ontwikkeling van populaties (niet ingrijpen)}

Stoppen met hoefdierbeheer leidt tot fluctuaties in aantallen die zijn terug te voeren op schommelingen in het voedselaanbod (Groot Bruinderink et al., 2004). Populaties hoefdieren kunnen exponentieel groeien wanneer niet beheerd wordt, zoals bekend is uit de Oostvaardersplassen en de Amsterdamse waterleidingduinen, en waarbij sterke effecten zichtbaar werden op de vegetatieontwikkeling (Cornelissen et al., 2014a; Groot Bruinderink et al., 2013b). Bij het niet beheren van hoefdierpopulaties is de verwachting dat dichtheidsafhankelijke regulatie vooral voor zal komen bij soorten als rund en edelhert en minder bij soorten als wild zwijn, damhert en moeflon (Putman, 1996; Van Wieren et al., 1999; Groot Bruinderink et al., 2009). Een dynamisch evenwicht rondom de draagkracht op basis van het voedselaanbod zal bij soorten als rund en edelhert vooral werken via juveniele reproductie (uitgestelde puberteit) en het niet jaarlijks meer drachtig worden van hindes. Wild zwijn en moeflon kunnen persistent instabiele aantalsschommelingen vertonen door hun hogere reproductie en (niet-)lineaire sterfte. Veel hoefdierpopulaties zijn tamelijk stabiel rondom draagkrachtniveau, hoewel dichtheidsonafhankelijke factoren (bv. weersomstandigheden) voor grotere schommelingen kunnen zorgen. Wanneer de draagkracht op basis van het natuurlijk voedselaanbod wordt overschreden, kan dichtheidsafhankelijke regulatie van de aantallen optreden en ontstaat soms het risico op een crash van de populatie waarbij 70-90\% van de dieren kan sterven (Young, 1994). Een zo massale sterfte hoeft geen bedreiging te zijn voor het duurzaam voortbestaan van een populatie, maar kan leiden tot grote, periodieke schommelingen van aantallen grazers, zoals bij de Soayschapen op Hirta (Schotland) (Clutton-Brock et al., 1992). Dit wordt veelal ongewenst geacht in het maatschappelijk debat vanwege ethische, maatschappelijke, economische en veterinaire aspecten.

Ook Groot Bruinderink et al. (2009) concluderen dat er over het effect van het niet beheren van wilde zwijnen onvoldoende bekend is. Aantallen wilde zwijnen kunnen in theorie sterk variëren, afhankelijk van fluctuaties in het voedselaanbod (mast). Er is echter niets bekend over natuurlijke dichtheden zonder beheer, natuurlijke dichtheidsafhankelijke terugkoppeling en het effect hiervan op vegetaties en biodiversiteit. Groot Bruinderink et al. (2004) gebruikten het model FORSPACE om diverse scenario's op Veluwezoom over een periode van 50 jaar door te rekenen. Bij het niet reguleren van alle hoefdiersoorten (rund, paard, edelhert, ree, damhert, wild zwijn) bereikten edelhert en damhert de grootste dichtheid en vertoonden alle soorten grote schommelingen in de aantallen per jaar. Rund, paard en ree zouden uit het systeem kunnen verdwijnen door competitie. Damherten bereikten in het model dichtheden van ca. 5-22 per 100 ha, edelherten van ca. 3-10 per 100 ha. Verrassend genoeg bleek uit het model dat hoge dichtheden van damhert en edelhert gunstig waren voor de verjonging van eik op leefgebiedsniveau. Een hoge begrazingsdruk zou kunnen leiden tot meer kiem-, vestigingsen groeiomstandigheden voor eik, onder andere doordat een meer open vegetatiestructuur ontstaat. Een succesvolle verjonging van eik in het bos vindt echter pas plaats wanneer er weinig ( $<1$ per 100 ha) hoefdieren zijn en voldoende licht beschikbaar is, zo leert de praktijk (zie paragraaf 3.5). 
In 2001 werd het populatiebeheer van edelherten en damherten in het natuurgebied Deelerwoud door Natuurmonumenten gestaakt (Huysentruyt \& Casaer, 2015). De edelhertenpopulatie stabiliseerden na ca. 10 jaar op een hoger niveau dan voor de start van het experiment. De damherten namen sterk in aantal toe en verkeerden ten tijde van de evaluatie nog steeds in een stadium van exponentiële groei. De dichtheid van edelherten en damherten bereikte tot 2014 ca. 20 dieren per 100 ha voor beide soorten.

Op de gehele Veluwe was de dichtheid van respectievelijk edelhert, damhert, ree en wild zwijn in de jaren 1990 gemiddeld 1,7 per100 ha, 0,3 per 100 ha, 7,8 per 100 ha en 2,5 per 100 ha (op basis van 60.000 ha benuttingsgebied; Faunabeheerplan Gelderland 2019-2025; Vereniging Wildbeheer Veluwe 2019). In de jaren daarna nam de stand toe. In de jaren 2010 was de dichtheid van respectievelijk edelhert, damhert, ree en wild zwijn 4,2 per 100 ha, 1,5 per 100 ha, 7,8 per 100 ha, 3,3 per 100 ha. $\mathrm{Bij}$ het niet reguleren van de aantallen zal de dichtheid naar verwachting verder toenemen.

Gezien de hierboven beschreven problematiek ligt het niet voor de hand dat een autonome populatieontwikkeling van hoefdieren verenigbaar is met de meeste terreindoelen op de Veluwe en de kwaliteitsdoelen van de Natura 2000-boshabitats op de aangewezen locaties. De verwachte dichtheden zullen veel hoger liggen dan de dichtheden waarbij voldoende verjonging van de meeste loofboomsoorten nog mogelijk is en zullen ertoe leiden dat veel populaties (bijzondere) kwaliteitssoorten en typische soorten zwaar onder druk komen te staan. Onduidelijk is wat er op langere termijn (decennia) zou gebeuren geen enkel hoefdier nog gereguleerd wordt. Naar verwachting treden dan grote aantalsschommelingen op bij wild zwijn en moeflon, terwijl de andere soorten naar verwachting op een hoog stabiel niveau voorkomen (edelhert, damhert) of verdwijnen uit het systeem door competitie (ree). De resterende begrazingsdruk lijkt op voorhand te hoog om de gewenste kwaliteiten van de Natura 2000-boshabitats te behouden, hoewel mogelijk periodiek korte periodes kunnen ontstaan met een lage wilddruk.

\subsection{Autonome ontwikkeling onder invloed van natuurlijke predatie}

Met de hervestiging van de wolf op de Veluwe is een nieuwe situatie ontstaan voor het wild op de Veluwe. Uitbreiding van de wolvenpopulatie - en eventueel ook de hervestiging (of herintroductie) van de lynx - legt een natuurlijke predatiedruk op de bestaande populaties. Dit kan gevolgen hebben voor de populatiegroottes en in ieder geval het terreingebruik van hoefdieren en dus ook op de effecten die zij hebben op de vegetatie.

\subsubsection{Wolf}

Sinds 2018 is de wolf officieel gevestigd op de Veluwe en in 2019 werden de eerste jongen geboren. Gezien de ontwikkelingen in buurland Duitsland, waar de populatie in 20 jaar toenam van 1 naar ruim 100 roedels, is het de verwachting dat ook Nederland in toenemende mate door zwervende wolven wordt aangedaan. Per roedel worden er vaak jaarlijks 5-8 welpen geboren, waarvan na de eerste winter ongeveer de helft nog in leven is. In natuurgebieden is de belangrijkste doodsoorzaak voor wolven een andere wolf. In een door de mens gedomineerde leefomgeving vormen het verkeer en illegale stroperij de belangrijkste doodsoorzaak (Groot Bruinderink et al., 2011).

\section{Aantallen \& dichtheid}

In Duitsland bedraagt tot op heden de dichtheid gemiddeld 0,02-0,04 wolven per 100 ha (Kluth \& Reinhardt, 2011). In Scandinavië is de hoogste dichtheid aan wolven (provincie Värmland) 7 paar met in totaal 34 wolven op $17.000 \mathrm{~km}^{2}$, oftewel 0,02 per 100 ha (Liberg et al., 2010). Er is een directe relatie tussen biomassa hoefdieren en aantallen wolven. Aangezien de dichtheid van hoefdieren nogal varieert in Europa, bestaat er dus niet zoiets als een 'normale' dichtheid. De Veluwe lijkt een geschikt leefgebied voor wolven. Als we uitgaan van ca. $200 \mathrm{~km}^{2}$ per territorium, dan zou er op de Veluwe plek zijn voor 4 à 5 roedels. Of dat ook gaat gebeuren en wanneer, is niet te voorzien. 
Dieet

In Duitsland is de dieetkeuze van wolven onderzocht door keutels te analyseren (Kluth \& Reinhardt, 2009). In meer dan de helft van de 1811 onderzochte keutels werden haren van reeën aangetroffen. Daaruit blijkt dat het ree de belangrijkste prooigroep vormt (ca. 55\%) en daarnaast edelhert (ca. $29 \%$, Figuur 20) en wild zwijn (ca. 32\%). Niet vermeld is hoe groot de populaties van deze prooidieren waren in het studiegebied en tevens kan met deze methode geen onderscheid gemaakt worden tussen daadwerkelijk gedood dan wel als aas gegeten prooien. Andere prooigroepen werden beduidend minder aangetroffen: haas/konijn $8 \%$, kleine zoogdieren $4 \%$, huisdieren $2 \%$, damhert $1 \%$, moeflon $1 \%$ en vruchten $1 \%$. Qua biomassa komt dit neer op ca. $50 \%$ ree, $25 \%$ edelhert en $17 \%$ wild zwijn.

Een volwassen wolf eet 3-15 kg per dag, afhankelijk van hoe lang geleden er voedsel beschikbaar was (Stubbe, 2008). Ze kunnen ook dagen hongeren. Volgens Mech (1970) heeft een wolf jaarlijks $1560 \mathrm{~kg}$ prooi nodig (4,2 kg per dag). In de Lausitz (D) is een berekening uitgevoerd om een indicatie te krijgen hoeveel hoefdieren er door een gemiddelde roedel wolven worden gepakt. Daarbij werd aangenomen dat de helft van de prooidieren een jong van dat jaar betrof, een wolf gemiddeld 5,4 kg per dag nodig heeft (waarvan $4 \mathrm{~kg}$ verteerd kan worden), een roedel gemiddeld uit 8 volwassen dieren en 4 welpen bestaat en ten slotte dat een welp de helft consumeert van een volwassen wolf. In de Lausitz doodt één wolf gemiddeld 65 reeën, 9 edelherten en 16 wilde zwijnen per jaar. Voor een gemiddelde roedel zijn deze cijfers: 400 reeën, 54 edelherten en 100 wilde zwijnen per jaar. Bij een territorium van 25.000 ha betekent dit 1,6 reeën, 0,22 edelherten en 0,4 wilde zwijnen per 100 ha. Een jaarbuit van naar schatting 2,2 stuks per 100 ha.

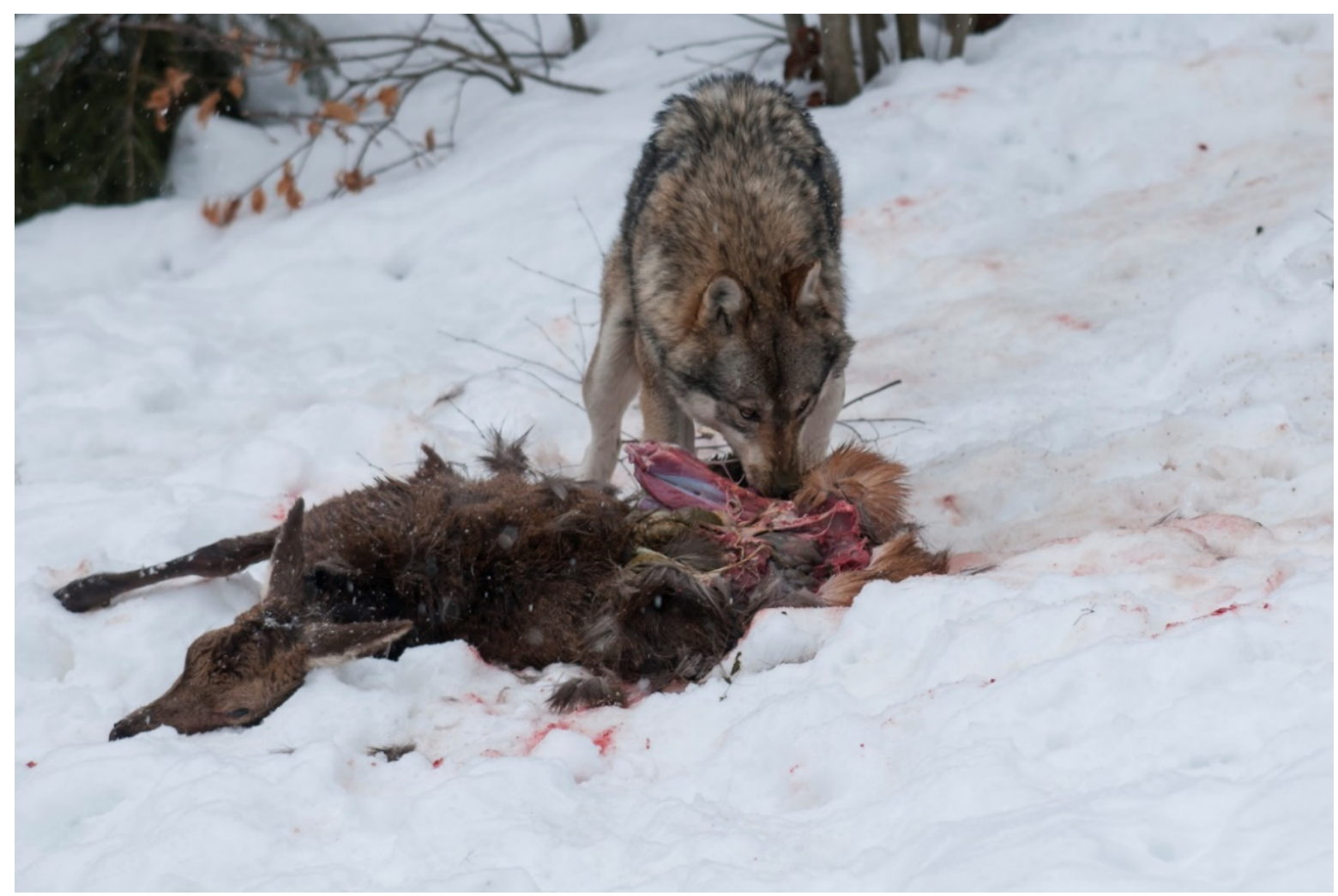

Figuur 20 Een wolf met gedood edelhert. 


\subsubsection{Lynx}

Ook de lynx lijkt heel geleidelijk zijn leefgebied uit te breiden. Deze soort kent echter een minder avontuurlijk dispersiegedrag, zodat de lynxenpopulatie zich meer als een trage olievlek uitbreidt. Voor de lynx blijkt vooral het oppervlak aaneengesloten bos de cruciale, en tevens ook de beperkende, factor te zijn (Lelieveld et al., 2019). De totale oppervlakte van geschikt leefgebied voor de lynx in Nederland bedraagt zo'n duizend vierkante kilometer. Deze gebieden staan echter niet in verbinding met elkaar én de meeste bosgebieden zijn te klein voor deze bosspecialist.

Lynxen zijn solitair levende dieren en waarschijnlijk hebben vrouwelijke dieren ca. $200 \mathrm{~km}^{2}$ als territorium nodig. Een man heeft ca. $300 \mathrm{~km}^{2}$ nodig en overlapt meerdere vrouwelijke territoria. Op de Veluwe is daardoor waarschijnlijk voldoende ruimte voor vier territoria van vrouwelijke lynxen met, overlappend, een à twee territoria van mannelijke lynxen (Mulder, 1992). Dit is te weinig voor het in stand houden van een duurzame populatie, tenzij er een robuuste verbinding van boshabitat komt naar het verspreidingsgebied in Duitsland.

Lynxen zijn in Europa vooral hoefdierjagers, zij het dat ze vooral kleinere hoefdieren als reeën en kalveren van edelherten pakken. Lynxen jagen meer vanuit dekking en overrompelen daarbij hun prooi. Gezien het geringe aantal lynxen dat de Veluwe kan herbergen en het gegeven dat ze in de komende jaren nog niet verwacht worden, zal deze soort hier niet verder behandeld worden.

\subsubsection{Effecten van wolf op hoefdieren}

Predator-prooirelaties zijn complex. In het algemeen reguleren de aantallen prooidieren de aantallen predatoren. Het is maar zelden omgekeerd. De invloed van predatoren hangt af van tal van parameters, zoals habitat, territoriumgrootte, weersomstandigheden (winters), voedsel, spectrum aan hoefdiersoorten, concurrenten, beschutting, menselijke bejaging en landgebruik (Fuller \& Sievert, 2001). Ook speelt mee dat wilde hoefdieren gebieden met een hoge concentratie aan wolven gaan mijden (Fuller \& Sievert, 2001). Wolven en hoefdieren hebben eeuwen samen geleefd en zijn dus ook samen geëvolueerd, wat heeft geleid tot wederzijdse morfologische en gedragsaanpassingen. Wolven staan aan de top van de voedselpiramide en kunnen op vier manieren andere soorten rechtstreeks of indirect beïnvloeden: 1 . als een soort gezondheidspolitie waarbij ze zieke of zwakke dieren doden en daarmee de prooidierpopulatie vitaler maken; 2. aantalsregulatie van prooidieren; 3. toename van aas voor aaseters en 4 . het reguleren van niet-prooidieren zoals middelgrote roofdieren (Mech \& Peterson, 2003; Mech \& Boitani, 2003).

\section{Regulering prooidieren}

Wolven zijn in staat populaties hoefdieren te limiteren, maar dat is niet altijd het geval (Mech \& Peterson, 2003; Mech, 1970; Bergerud, 1971). Meerjarig onderzoek in Białowieża (Polen) liet zien dat wolvenpredatie alleen voor edelherten een belangrijke doodsoorzaak was: ongeveer $40 \%$ van de jaarlijkse aanwas werd afgeroomd. De predatieratio bleek omgekeerd gerelateerd aan de dichtheid van edelherten: indien de edelhertpopulatie afnam, nam de predatiedruk toe. Wolven bleken dus geen stabiliserende invloed te hebben (Jedrzejewski et al., 2010).

Omdat wolven sterk territoriaal zijn en voldoende grote territoria claimen om de roedel van voedsel te voorzien komt overbejaging van prooidierpopulaties zelden voor. Wel kunnen wolven in onnatuurlijke situaties populaties sterk beïnvloedden, zoals de moeflon in Nederland. Deze soort komt van nature niet voor in gebieden met grote predatoren, en als die er voor zouden komen, is het natuurlijke antipredatorgedrag van schaap- en geitachtigen heel hard een bergklif op rennen. Die zijn er niet op de Veluwe, vandaar dat te voorzien is dat de moeflon wel sterk in aantal beïnvloed zal worden door wolven.

Het is waarschijnlijk dat er in de komende jaren meer wolven op de Veluwe een territorium zullen vinden. Of ze zich weten te handhaven, is weer afhankelijk van de mens: illegale vervolging is een belangrijke factor waardoor wolven weer verdwijnen. Wanneer wolven komen, hoeveel dat er zullen worden en wat ze precies gaan doen, is niet te voorzien. Wolven kennen een breed scala aan karakters en hun sociale groepsdynamiek is divers. Indien de roedels groot worden, oftewel uit veel 
volwassen wolven bestaan, kunnen ze zich specialiseren op grote hoefdieren als edelherten. Blijven het kleinere roedels, dan zal ree de belangrijkste prooi zijn. Elke roedel is uniek in hoe ze zich gaan gedragen, bijvoorbeeld of jongen al snel wegtrekken of juist blijven en dus of de roedels groot worden of niet. Vervolgens blijken sommige wolven of roedels zich echt te specialiseren. In MecklenburgVorpommern heeft dat ertoe geleid dat het aantal vanuit beheer te schieten edelherten behoorlijk is afgenomen, omdat de lokale wolvenroedel zich specialiseert op edelherten, met name kalveren. Hoe dat uitpakt op bijvoorbeeld bosverjonging, is nog in onderzoek (N. Stier, pers. med.).

\section{Gedragsverandering bij prooidieren}

Naast het feit dat wolven hoefdieren doden, is hun belangrijkste effect het beïnvloeden van het gedrag van hoefdieren. Herten kunnen hun gedrag aanpassen qua groepsgrootte, activiteitenpatroon en terreingebruik. Gebieden die gevaarlijk zijn omdat ze kwetsbaar zijn voor predatie, zullen hoefdieren op die momenten liever vermijden. Dit wordt het 'Landscape of Fear' genoemd (landschap van angst; Van Ginkel et al., 2019a, b). Dit kan tot gevolg hebben dat er meer variatie in begrazing optreedt, wat dus bevorderlijk kan zijn voor onder andere bosverjonging. In Yellowstone National Park is dit goed onderzocht. Na de introductie van wolven in 1995 nam het aantal hoefdieren af en werd het ecosysteem diverser, met ook meer vegetatie groei en bosontwikkeling. Het proces is echter erg complex vanwege klimaatverandering (grote bosbranden de afgelopen jaren), grizzlyberen die in aantal toenemen omdat ze onder andere profiteren van door wolven gedode herten die ze zich toeeigenen, afname van coyotes vanwege concurrentie met wolven etc. Desondanks vermelden de wetenschappers in Yellowstone dat het positieve effect van wolven op het ecosysteem indrukwekkend lijkt (Smith et al., 2016). Er is een toenemende aandacht voor het belang van top-downregulatie door grote roofdieren als wolven voor het functioneren van ecosystemen, waarbij de aanwezigheid van predatoren effecten heeft die ver in de voedselketen doordringen (Estes et al., 2011).

Een ander voorbeeld van gedragsverandering komt uit Afrika. Atkins et al. (2019) onderzochten het effect van het experimenteel nabootsen van roofdieren op het gedrag van hoefdieren (bushbucks) in een nationaal park in Mozambique. Bushbucks houden van dekking en trekken zich bij gevaar terug in het bos, in tegenstelling tot enkele andere grazers, die juist de open vlakte op rennen bij gevaar. Sinds wilde honden en grote katachtigen zijn uitgeroeid in het gebied durven de bushbucks meer op de vlakte te grazen met overbegrazing tot gevolg. Dieetstudies tonen aan dat ze daarbij voedselrijkere planten consumeren. Oftewel het is voor deze soort een afweging tussen voedselrijk eten versus predatiegevaar. De onderzoekers hebben vervolgens enkele dieren met gps-loggers uitgerust en aansluitend het effect van roofdiergeluid en geur (uitwerpselen en urine) op het gedrag van de bushbucks onderzocht. De soort bleek sterk te reageren op deze zintuigelijke indicaties van roofdieraanwezigheid, met als gevolg dat ze de grasvlakte meer gingen vermijden. De onderzoekers concluderen dat voor bushbucks de open vlakte veranderde van een 'landscape of fear' naar een 'landscape of fearlessness' na het uitroeien van de grotere roofdieren en dat die uitroeiing dus grote gevolgen heeft voor de plant- en prooipopulaties. De beleving van die angst is wel soortspecifiek; niet alle hoefdieren vertonen hetzelfde gedrag als reactie op de aanwezigheid van een roofdier of gevaar. Tevens melden de onderzoekers dat de gedragsaanpassing van bijvoorbeeld de bushbuck aan het afwezig zijn van roofdieren reversibel is en dat dat ook kunstmatig kan worden nagebootst. Desondanks bevelen ze aan om de grote roofdieren weer terug te brengen in het ecosysteem (Atkins et al., 2019).

Of hoefdieren hun gedrag gaan veranderen als gevolg van de aanwezigheid van wolven is van vele factoren afhankelijk, zoals trefkans hoefdier-wolf, pakkans, overige stressfactoren als recreatie en beheer, voedselbeschikbaarheid etc. Dit hangt weer direct samen met hoe de Veluwe is ingericht qua padendichtheid, rustgebieden, beheer, ouderdom van het bos etc. Het is waarschijnlijk dat hoefdieren hun gedrag zullen gaan aanpassen, met name door alerter te worden, wat betekent dat ze ook schuwer worden voor mensen met als gevolg dat beheerjacht minder eenvoudig zal zijn. Of wolven ook de aantallen van hoefdieren waarneembaar gaan beïnvloeden, is maar zeer de vraag, aangezien menselijke invloeden op het leefgebied en de hoefdieren groot zijn. Recent onderzoek in het Poolse Białowieża vond nauwelijks effecten van de aanwezigheid van wolven op edelherten (Van Ginkel, 2020). Op lokale schaal wordt het gedrag beïnvloed, met name wanneer obstakels aanwezig zijn die zicht of vluchtroutes blokkeren (Van Ginkel et al., 2019a), met een lokale reductie van vraat aan bosverjonging tot gevolg. Op basis van Van Ginkel (2020) is het niet te verwachten dat de wolf op de Veluwe een grote invloed zal gaan hebben op de bosverjonging, ook vanwege de relatief jonge leeftijd van het bos. Het effect zal hooguit lokaal zijn. 


\section{Wolven in het Veluwse landschap}

Mocht de Veluwe als groot natuurgebied via robuuste natuurcorridors met omliggende natuurgebieden met hoefdierpopulaties verbonden kunnen worden, ontstaat er meer ruimte voor natuurlijk processen in plaats van menselijk bepaald beheer van natuur en hoefdierpopulaties. Dit zal de levensvatbaarheid van de populaties wilde hoefdieren ten goede komen, mede vanwege de mogelijkheid voor hoefdieren om weer via natuurlijke selectie en adaptatie hun vitaliteit te sturen. Daarnaast kunnen hoefdieren via de corridors weer migreren naar voedselrijke gebieden, afhankelijk van het seizoen en het klimaat etc. Wolven kunnen in deze situatie een enigszins regulerende invloed hebben op de populatiegrootte en het gedrag van hoefdieren, maar dit vereist wel veel meer ruimte voor de natuur en natuurlijke processen dan nu mogelijk is en/of wordt toegelaten. De kaart met een visie op een meer natuurlijk Nederland in 2120 (Baptist et al., 2019) geeft wat dat betreft een interessant doorkijkje. Het blijft echter zeer de vraag in hoeverre dit, in de huidige landschappelijke context, ook de voorwaarden kan scheppen voor voldoende bosverjonging.

Samenvattend is het waarschijnlijk dat zich meerdere roedels wolven op de Veluwe zullen vestigen. Hun belangrijkste voedsel zal bestaan uit wilde hoefdieren, met name ree, aangevuld met zwijn, damhert en edelhert. De hoefdiersoortensamenstelling kan wel (lokaal) veranderen door selectieve predatie. Moeflon zal wellicht geheel verdwijnen. Het is niet waarschijnlijk dat wolven in staat zijn via hun invloed op hoefdieren de bosverjonging en ondergroei substantieel te beïnvloeden. Dit scenario zal daarom in de huidige landschappelijke context van en met het huidige beheer op de Veluwe naar verwachting niet veel anders uitpakken dan het scenario met autonome groei van hoefdierpopulaties zonder predatie (zie paragraaf 6.1). Mogelijk ontstaan, afhankelijk van de ruimtelijke configuratie, wel lokaal lagere dichtheden door het ontstaan van een 'landscape of fear', waardoor de effecten van begrazing, in ieder geval lokaal, enigszins verlicht kunnen worden.

\subsection{Huidig beheer}

Het huidige hoefdierbeheer is gedifferentieerd naar leefgebieden waarin verschillende doelstanden zijn vastgelegd, afhankelijk van de beheerdoelen en -inzet. De doelstanden worden bepaald door de Faunabeheereenheid Gelderland op basis van een afweging tussen maatschappelijke belangen, zoals het vermijden van schade (met name aan verkeer en gewassen), effecten op het ecosysteem en wildzichtbaarheid. Ook wordt de gunstige staat van instandhouding van de hoefdierpopulaties daarin meegenomen (zie paragraaf 4.1.3). De doelstanden voor 2019-2025 zijn voor de Veluwe vastgesteld op 1.440 edelherten, 495 damherten en 1.100 wilde zwijnen. Voor reeën is de doelstand tussen de 10.350-14.820, maar deze doelstand geldt voor de hele provincie Gelderland (FBE Gelderland, 2019). Uit de jaarrapportage grofwild 2018-2019 (VWV 2019) blijkt dat de doelstanden voor edelhert en wild zwijn sinds 1990 geleidelijk zijn verhoogd (zie Figuur 21). De doelstand voor edelherten is verhoogd van ca. 900 in 1990 naar ca. 2.000 in 2019, een ruime verdubbeling. Voor wilde zwijnen is de doelstand verhoogd van ca. 700 in 1991 naar ca. 1.400 in 2019, ook een verdubbeling. Volgens het Faunabeheerplan Grote Hoefdieren 2019-2025 (FBE Gelderland, 2019) moeten deze doelstanden nu weer omlaag, waarbij herstel van de bosverjonging expliciet als een belangrijk motief wordt genoemd. Ook Gedupeerde Staten Gelderland (2019) signaleren dit nadrukkelijk en geven richting aan mogelijke extra maatregelen hiertoe, met name via een verdere professionalisering in de uitvoering van het populatiebeheer. 


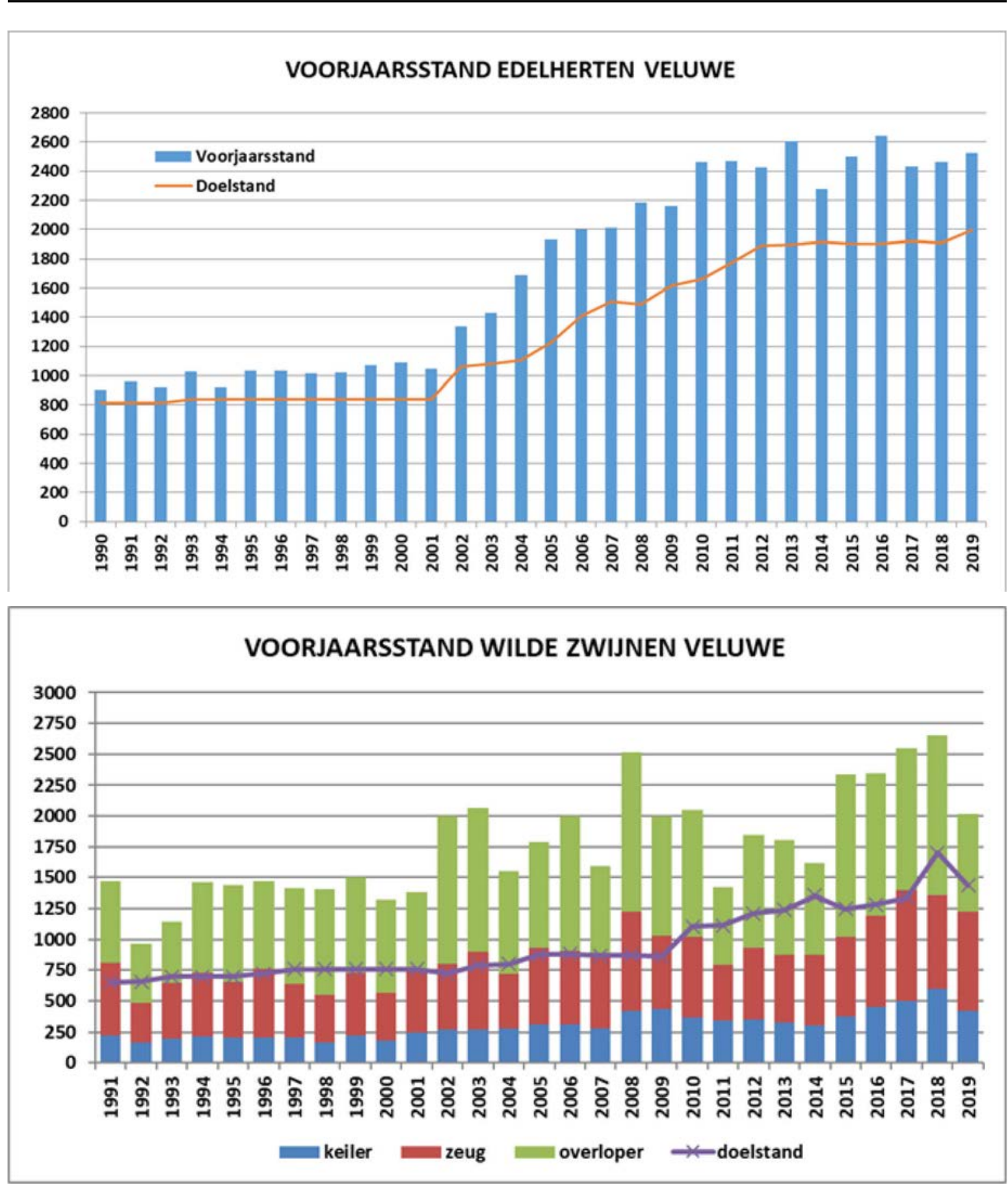

Figuur 21 Voorjaarsstanden en doelstanden edelherten (links) en wild zwijn (rechts) op de Veluwe in de afgelopen decennia. De aantallen voor wild zwijn in 2019 zijn een sterke onderschatting van de werkelijke aantallen (G.-J. Spek, pers. med.). Figuren uit Vereniging Wildbeheer Veluwe (2019).

In paragraaf 4.3 is al aangegeven hoe lastig het is om vast te stellen hoeveel hoefdieren in een bepaald gebied aanwezig zijn. Op de Veluwe wordt de populatiegrootte geschat op basis van zichtwaarnemingen. Meestal wordt er in het voorjaar tijdens een tweedaagse periode geteld op een avond, een ochtend en de volgende avond. Aansluitend kan ook gebruik worden gemaakt van schijnwerpertellingen en eventueel andere technieken. De telmethoden worden niet per deelgebied op dezelfde wijze uitgevoerd. De jaarrapportage VWV 2018-2019 vermeldt dat er voor sommige gebieden uiteindelijk beduidend meer edelherten zijn aangetroffen dan verwacht en dat voor andere gebieden de prognose overeenkwam met de telresultaten. Voor wilde zwijnen vermeldt de jaarrapportage 20182019 (VWV 2019) dat de nauwkeurigheid van de actuele tellingen veel lager was dan 2017-2018, mogelijk door de vele mast die nog overal aanwezig was. Ook werden er vele aanvullende meldingen van rotte wilde zwijnen gedaan, waardoor de zomerstand beduidend hoger is uitgekomen. Dit bevestigt de al eerder in 4.3.1 besproken bevindingen van Groot-Bruinderink et al. (2013a), namelijk dat tellingen op basis van zichtwaarnemingen zeer onbetrouwbaar zijn. 
Op basis van de telresultaten wordt de voorjaarsstand bepaald en worden de aanwas en zomerstand berekend. Hierin wordt ook de verwachting van de hoeveelheid mast meegenomen (Vereniging Wildbeheer Veluwe (VWV) 2019). De verwachte stand wordt vergeleken met de doelstand en vervolgens wordt het te realiseren afschot bepaald, onderverdeeld in leeftijds- en geslachtsklassen. De toewijzing kan gedurende het seizoen worden bijgesteld, afhankelijk van de ontwikkelingen in het veld. De jaarrapportage VWV 2018-2019 vermeldt dat voor edelherten $80 \%$ van de toewijzing van 1209 te schieten herten is gerealiseerd. Voor wilde zwijnen is bepaald dat er 4046 geschoten mochten worden, waarvan slechts $54 \%$ werd gerealiseerd. Tegelijkertijd moet worden geconstateerd dat het wel mogelijk zou moeten zijn om de doelstanden te realiseren, blijkens de verschillende deelgebieden waar het toegewezen afschot wel werd gerealiseerd.

Afschot lijkt zich bij het wild zwijn te richten op de volwassen dieren en veel minder op de biggen en overlopers. Daarnaast lijken volwassen mannen, zowel bij edelherten en wilde zwijnen, relatief intensiever bejaagd te worden dan de vrouwen, waardoor de reproductiecapaciteit van de populaties relatief hoog blijft. Van de te beheren volwassen edelherten is $79 \%$ van de geweidragers geschoten en $72 \%$ van de hindes (VWV, 2019). Voor de zwijnen betreft dat $88 \%$ van de te beheren keilers en $68 \%$ van de zeugen. Bij de edelherten wordt dan ook concreet een vervrouwelijking van de populaties vastgesteld. Deze scheve geslachtsverhouding kan van vele factoren afhankelijk zijn, zoals de draagkracht van het gebied, maar ook het beheer kan daarbij een rol spelen. De laatste (circa) 10 jaar blijken er na de eerste winter aanzienlijk minder mannelijke edelhertkalveren geschoten te worden dan vrouwelijke (VWV, 2019), terwijl dat bij geboorte waarschijnlijk gelijk ligt. Dit kan het gevolg zijn van een verschil in fysiologie tussen mannelijke en vrouwelijke edelherten, waarvan bekend is dat mannelijke herten, met name kalveren, gevoeliger zijn voor schaarste van essentiële mineralen (Groot Bruinderink et al., 2012). Als gevolg van onder andere de stikstofdepositie op de arme zandgronden is het niet onwaarschijnlijk dat dat ook voor edelherten gevolgen heeft voor de beschikbaarheid van essentiële mineralen (zoals natrium, kalium en calcium), met name voor de mannelijke kalveren. Kortom, de vervrouwelijking van de edelhertenpopulatie op de Veluwe is waarschijnlijk het gevolg van matige voedselkwaliteit (vooral mannelijke kalveren) en selectief beheer, waarbij relatief meer geweidragers geschoten worden (trofeejacht).

Het is duidelijk dat de afgelopen decennia de standen zijn opgelopen op de Veluwe en in veel gebieden structureel hoger liggen dan de doelstanden, omdat de vastgestelde quota van te schieten dieren niet worden gerealiseerd. Er worden in het huidige faunabeheerplan geen aantallen genoemd qua doelstand, maar alleen hoeveel schade en aanrijdingen worden geaccepteerd. In tegenstelling tot de voorgaande periode lijkt de bosverjonging een belangrijk aandachtspunt geworden in het faunabeheerplan. Voor grote delen van de Veluwe geldt dat de huidige standen leiden tot een wilddruk op de vegetatie, die niet toelaat dat loofbomen een substantieel deel uitmaken van de bosverjonging. Het nieuwe faunabeheerplan lijkt in te steken op lokaal maatwerk, echter laat dat aan de beheerder. Door de grote variatie aan, en sterke versnippering van, beheerdoelen en de grote actieradius van hoefdierpopulaties van met name edelhert, is het afwachten in hoeverre dat de bosverjonging zal bespoedigen. Indien dit weer op bescheiden lokale schaal gebeurt, dan is het risico dat lokaal wellicht een lage stand wordt gerealiseerd, maar dat bosverjonging alsnog niet van de grond komt door nachtelijke voedselstrooptochten van hoefdieren uit de omgeving.

Het huidige beheer en de daarin aangehouden doelstanden leiden tot een te hoge wilddruk op de boshabitattypen. Dit leidt tot een sterke belemmering van de verjonging van gewenste boomsoorten en daarmee tot een verarming van de nieuwe generatie bos, met daarin een groot aandeel ongewenste soorten (met name exoten) en een homogenisering van de bosstructuur (ontbreken van een struiklaag). Het is onduidelijk in hoeverre populaties van (bijzondere) kwaliteitssoorten en typische soorten te lijden hebben onder de huidige wilddruk. Er zijn echter wel duidelijke aanwijzingen dat de grootschalige bodemverstoring door wild zwijn negatieve effecten heeft op verschillende typische soorten, met name in Oude eikenbossen. 


\subsection{Generieke verlaging van de wildstand}

Een generieke verlaging van de wildstand zal leiden tot een lagere wilddruk. In dit scenario wordt ervan uitgegaan dat binnen een leefgebied op de Veluwe de aantallen vlakdekkend worden gereduceerd tot een lager niveau dan nu wordt bereikt met het huidige faunabeheer. De vraag is hoe laag de aantallen dienen te zijn om de gewenste kwaliteiten van de Natura 2000-boshabitats op de aangewezen locaties te behouden of te verbeteren (zie paragraaf 3.5).

Voor het stimuleren van de verjonging van loofbomen lijkt een algehele (periodieke) verlaging van de populatiegrootte een effectieve methode voor het verlagen van de wilddruk tot een gewenst niveau. Onbekend is hoelang de wilddruk laag moet blijven om de terreindoelen op de Veluwe en de gewenste kwaliteiten van de Natura 2000-boshabitats op de aangewezen locaties te realiseren (zie paragraaf 2.2 en 2.3). Dit scenario vereist in eerste instantie een flinke inspanning om het benodigde afschot te realiseren en later een strakke regie op het behaalde afschot om de stand op een laag niveau te houden. In de praktijk is dit haalbaar, immers, in het verleden lagen de aantallen hoefdieren beduidend lager en soorten zijn zelfs uitgeroeid door een hoge jachtdruk (zie paragraaf 2.1.3). Nadeel van dit scenario is dat de populatiegrootte dusdanig laag kan worden dat er geen sprake meer zal zijn van een MVP (zie paragraaf 4.1.3). Mocht dit tot problemen leiden, dan zou dit eenvoudig kunnen worden opgelost door af en toe een aantal genetisch niet-verwante dieren bij te plaatsen. Daarnaast zal door de verkleinde populaties de wildzichtbaarheid afnemen. Door een slimme zonering en aangepaste jachtuitoefening zou de wildzichtbaarheid wellicht nog op een acceptabel niveau kunnen worden gehouden (zie paragraaf 6.5). Mogelijk dat toepassing van dit scenario op een deel van de Veluwe waar de belangrijkste Natura 2000-boshabitats liggen, kan worden toegepast (zie paragraaf 5.5).

\subsection{Gedifferentieerde bejaging en beheer op maat}

De tot nu toe besproken scenario's betreffen alle in principe het gehele oppervlak van de Veluwe, of grote deelgebieden daarbinnen (orde van grootte: de wildbeheereenheden). De verschillende terreindoelen variëren echter op veel kleinere schaal. Dit geldt zeker voor de aangewezen boshabitattypen, die vaak als een archipel in een zee van niet-kwalificerende bostypen en heideontginningsbossen liggen. De vraag is daarmee aan de orde of er ook op kleinere schaal maatregelen genomen kunnen worden waarmee de wilddruk lokaal kan worden verlaagd door het beïnvloeden van het gedrag van de dieren en hun terreingebruik te sturen.

Hoefdieren kunnen sterke gedragsresponsen vertonen als reactie op jacht, zoals dat ook het geval is bij predatie door roofdieren (Creel \& Christianson, 2008). Gedragsveranderingen bestaan voornamelijk uit het vermijden van riskante gebieden in tijd en ruimte en daarnaast uit onder andere verandering van het foerageergedrag, de groepsgrootte en de fysiologie. Deze reactie van prooidieren op roofdieren wordt de 'Ecology of Fear' genoemd, oftewel ecologie van de angst (Brown et al., 1999; zie ook Van Ginkel (2020) en paragraaf 5.2).

Een mogelijk kansrijke methode om de wilddruk lokaal te verlagen, is om de wijze van jacht via gedifferentieerd afschot zodanig te veranderen dat het gaat lijken op predatie door roofdieren: 'Hunting for Fear' (Cromsigt et al., 2013), wat zich laat vertalen als 'schrikjacht' en door Kuper (2018) 'ecologische jacht' genoemd. Het richt zich op het veranderen van het gedrag van hoefdieren, bijvoorbeeld door ze weg te houden uit gebieden waar hun invloed niet of minder gewenst is.

Een dergelijke jachtmethode beoogt de predatie door roofdieren te simuleren en omvat bijvoorbeeld jaarrond bejaging, 's nachts jagen, jagen voor de voet met honden in plaats van uit een statische positie, sterke focus qua afschot op jonge dieren als biggen, kalveren en jaarlingen etc. Eventueel kan dit worden aangevuld met het nabootsen van roofdieren via het uitleggen van uitwerpselen of het afspelen van geluid (Atkins et al., 2019), maar daar zijn door Van Ginkel (2019b) wat betreft wolf en edelhert geen overtuigende resultaten mee vastgesteld. Op ree na zijn de meeste hoefdieren op de Veluwe sociale groepsdieren, met name de vrouwelijke dieren en hun nakomelingen. De leidzeug of leidhinde zijn daarbij matriarchen die uit ervaring weten waar en wanneer het veilig is, waar voedsel 
en water te vinden is etc. De rest van de groep volgt vooral hun voorbeeld. Door niet die oudere vrouwen in de sociale groep te schieten, maar juist de jeugdige dieren, is er een numeriek effect (minder dieren), maar vooral ook een leereffect: de matriarch leert waar en wanneer het wel of niet veilig is en zal het gedrag van de groep daarop sturen. Volwassen mannelijke zwijnen (keilers) en edelherten (geweidragers) leven meer in los-vast-groepen of solitair. Daar zal dit effect wellicht minder prominent zijn, maar het is wel aannemelijk dat de oudere mannen beter dan de jongere mannen kunnen inschatten waar het veilig is op basis van ervaring en het gedrag van de vrouwen. Met andere woorden: ook hier is aan te raden om het afschot te richten op de jongere dieren. Al met al vergt dit een heel andere wijze en organisatie van de jacht en een nauwe samenwerking tussen terreineigenaars.

Om ecologische jacht op de Veluwe succesvol te maken, is maatwerk nodig en zal uitgezocht moeten worden in welke gebieden men de effecten van hoefdieren wil verminderen (zonering), op welke schaal dit uitgevoerd moet worden en hoe lang dit moet worden volgehouden. Het ligt voor de hand om schrikjacht vooral daar uit te oefenen waar de kans op negatieve effecten van een hoge wilddruk het hoogst is, zoals rond landbouwenclaves of drukke wegen, maar ook in bosgebieden waar verjonging van loofboomsoorten gewenst is of populaties (bijzondere) kwaliteitssoorten onder druk liggen, met name in de aangewezen boshabitattypen. De zonering van intensief bejaagde gebieden, en gebieden waarin de jachtdruk minder is, moet zodanig zijn dat de hoefdieren niet opgesloten raken. Bovendien zou het effect van bejaging kunnen worden versterkt door andere verstorende activiteiten af te stemmen op deze zonering, zoals de locatie van wandel-, mountainbike- en ruiterroutes (zie Figuur 22). Die activiteiten kunnen dan verlaagd worden in de gebieden waar de stand hoger mag zijn; daar worden dan rustige gebieden gecreëerd waar hoefdieren zich veilig voelen. Een dergelijke concentratie van publieksactiviteiten is echter weer nadelig voor andere kwaliteiten van boshabitattypen, zoals de aanwezigheid van verstoringsgevoelige broedvogels.

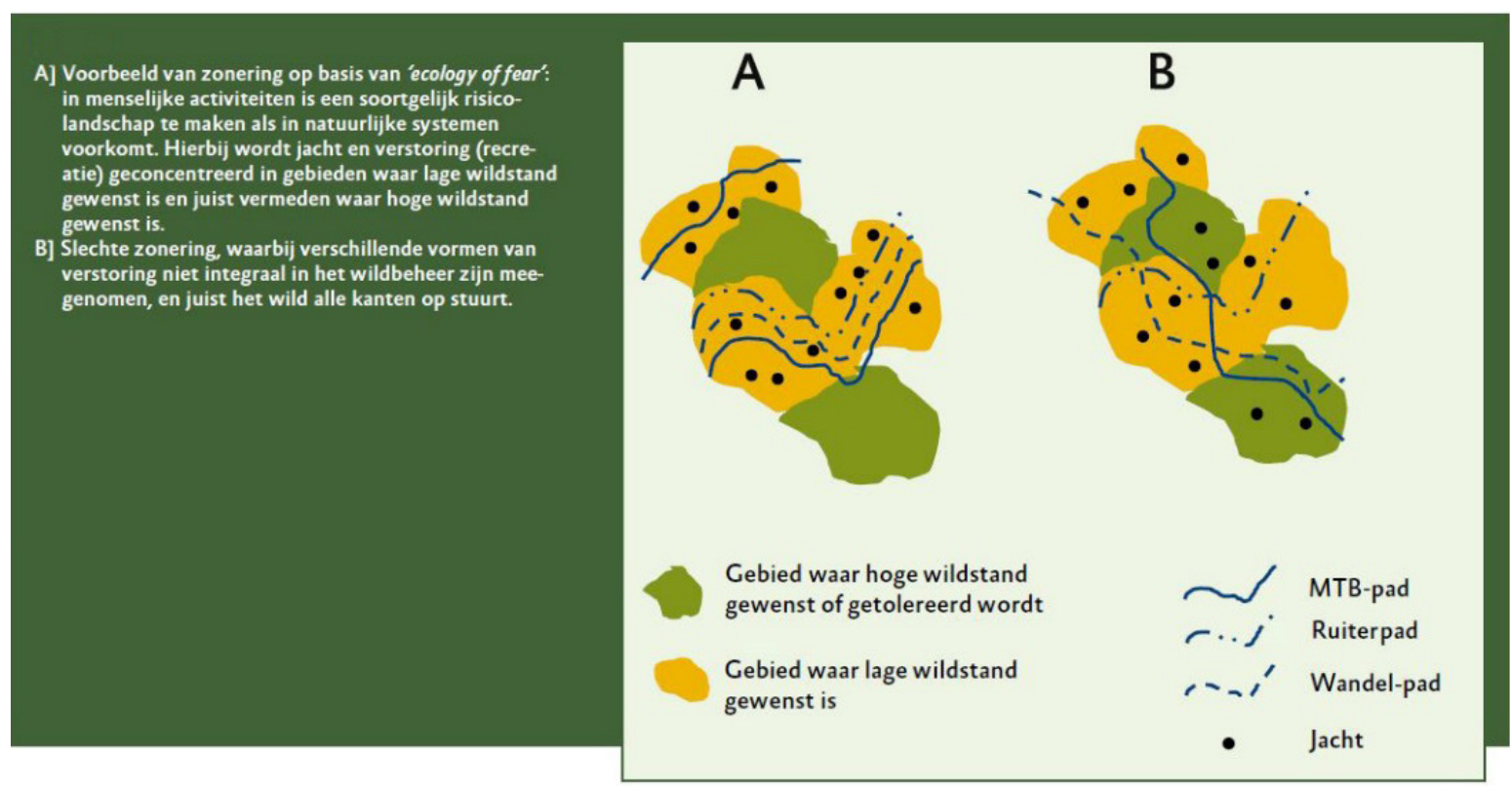

Figuur 22 Voorbeeld van een goede zonering op basis van 'Ecology of Fear $(A)$ met geconcentreerd afschot en recreatieve activiteit, en een slechte zonering (B), waarbij alle activiteiten willekeurig door elkaar heen lopen. Figuur overgenomen uit Cromsigt \& Kuiper (2018).

Het is nog niet duidelijk op welke schaal een dergelijke aanpak effectief zal zijn. Ten eerste zal dit afhangen van de aanwezige hoefdieren. Voor het territoriale ree zal een kleiner gebied volstaan dan voor de veel mobielere en in sociale groepen levende soorten zoals edelhert en damhert. Op dit moment wordt gedacht over het opzetten van een pilot waarbij gebieden van 100 ha worden aangehouden voor het uitvoeren van schrikjacht, maar het is sterk de vraag of dit voldoende is voor een soort als edelhert met een actieradius van vele kilometers en een leefgebied tot enkele duizenden hectares groot (Van den Broek, 2015; Van Woersem \& Elders, 2016). 
Omdat het doel in de context van bosgebieden zich vooral richt op bosverjonging, moeten de omstandigheden gecreëerd worden om die verjonging ook succesvol te laten ontstaan. Om reden van efficiency moeten gebieden waarin schrikjacht wordt gepland van tevoren worden voorbereid op verjonging, bijvoorbeeld door bossen sterk te dunnen of verjongingsgroepen te kappen in het bestaande bos. Vervolgens moet de verjonging voldoende tijd krijgen om op te groeien tot een grootte waarin die niet meer kwetsbaar is voor blad- en bastvraat. Dit zal zeker een periode van 10-15 jaar moeten zijn, zo niet langer.

Tevens zal er besloten moeten worden hoe hoog de wilddruk kan zijn in de 'rustige' gebieden. Bij een gelijkblijvende wilddruk zoals die nu heerst, moet dan worden geaccepteerd dat in de 'rustige' gebieden de verjonging van loofboomsoorten langdurig uitblijft en daar waar verjonging plaatsvindt, deze zal worden gedomineerd door naaldbomen. In feite houdt dit in dat zonder een verdere aantalsreductie de problemen met een hoge wilddruk alleen lokaal worden opgelost.

Deze verandering van jachtwijze en -organisatie vereist een omslag bij de uitvoerders van het afschot. Van oudsher kent jacht weidelijkheidsregels en is het meer ingestoken op het bemachtigen van buit of het reduceren van aantallen dan op het veranderen van het gedrag van dieren. Jacht in de voortplantingsperiode is vanuit weidelijkheid bijvoorbeeld onverantwoord, terwijl dit voor aantalsregulatie wel efficiënt zou zijn (Apollonio et al., 2011). Bovendien moet regelgeving worden aangepast om aangepaste jachttechnieken mogelijk te maken. Het huidige faunabeheerplan Veluwe biedt hiervoor reeds openingen. Een volledig andere aanpak van de zonering is ook een majeure opgave: de huidige versnippering van eigenaarschap en beheermethoden over de Veluwe is groot. Dit geldt tevens voor de recreatiezonering en inrichting van rustgebieden voor natuur. Daarnaast heeft de huidige wijze van hoefdierbeheer meer weg van vrijblijvende jacht dan van gedisciplineerd populatiebeheer met ondersteunend afschot, worden de doelstanden nu al niet gehandhaafd en is op dat aspect dus een grote behoefte aan professionalisering (zie ook paragraaf 5.3). Kortom, gedifferentieerde bejaging en beheer op maat is een kansrijke methode, maar vergt wel een grote verandering in de benadering, organisatie en regie van populatiebeheer van hoefdieren op de Veluwe.

Maatwerk, zoals gedifferentieerde jacht, kan lokaal de wilddruk sterk reduceren om zo gunstige omstandigheden te creëren voor de verjonging en tijdelijk de druk op populaties van (bijzondere) kwaliteitssoorten te verlagen. De schaal waarop deze maatregel uitgevoerd kan worden, varieert, maar moet substantieel zijn (orde van grootte tientallen $\mathrm{km}^{2}$ ) wanneer populaties edelhert of damhert moeten worden beheerd. Op een dergelijke schaal kan de wilddruk in de grotere complexen van aangewezen boshabitattypen in zijn geheel worden verlaagd. De maatregel biedt geen soelaas voor de overige delen, waarmee de bosontwikkeling in die delen nog steeds onder grote druk blijft staan.

\subsection{Afleiden en afweren}

Naast directe maatregelen als afschot kan de wilddruk in theorie lokaal worden gestuurd door hoefdieren af te leiden van plekken waar hun activiteiten ongewenst zijn of af te weren door een perceptie van gevaar te creëren.

Afleiding kan door het aanbieden van voedsel op geconcentreerde plekken. Dit kunnen voedzame wildweides zijn waar dieren kunnen grazen, bladakkers waar bomen als hakhout worden beheerd en waardoor grote hoeveelheden bladeren en knoppen geconcentreerd aanwezig zijn. Bijvoeren is bij wet verboden waar het bedoeld is om de stand van de populatie te bevorderen. Overigens is het wel toegestaan om lokaal in kleine hoeveelheden voer aan te bieden (mais, appels) om dieren naar specifieke plekken te lokken ten behoeve van wildtellingen en om het vergroten van de wildzichtbaarheid of een efficiënt afschot.

In veel gebieden in Europa wordt wintervoedering toegepast om het wild hiermee af te leiden van de kwetsbare bosverjonging. De effectiviteit van deze maatregel is niet duidelijk bewezen (Putman \& Staines, 2004). In een onderzoek in Oostenrijk toonden Arnold et al. (2018) door middel van gezenderde edelherten aan dat deze zich in de winter inderdaad meer concentreerden rondom voederplekken en dat zij kwetsbare verjongingen minder bezochten in een straal tot 1,5 km rondom 
de voederstations. Verder weg van de voederstations verdween dit effect weer. Hun conclusie was dat bijvoeren leidt tot een toename in de populatie door betere conditie van de dieren en dat andere manieren van populatiebeheer veel effectiever zijn. In het Bayerische Wald gaat men nog een stap verder door de herten in de winter op te sluiten in grote enclosures en daar bij te voederen om zo de wilddruk in het bos tijdens de winter te verlagen.

De toegang tot voedselrijke gebieden kan, bij gelijkblijvende dichtheden, de vraatdruk in armere gebieden verlagen. In deze context zouden de ecologische poorten een belangrijke rol kunnen spelen. Toegang tot de uiterwaarden kan seizoenmigratie op gang brengen tussen de Veluwe en het rivierengebied, waardoor deze voedselrijke gebieden als een natuurlijke afleiding zorgen voor vraat op de hoge, arme zandgronden.

Door dieren moedwillig bloot te stellen aan prikkels die zij als gevaar interpreteren, kan in theorie de wilddruk lokaal worden verlaagd. Te denken valt aan het verhogen van de recreatiedruk of het blootstellen van hoefdieren aan signalen van hun predatoren. Voor dit laatste hebben Van Ginkel et al. (2019b) proeven gedaan met wolvenurine op de Veluwezoom. Dit leidde vrijwel niet tot enige respons van de herten. Opvallend was dat de geur van een zeepoplossing als controle wel een reactie in de herten teweegbracht in gebieden waar de herten niet aan mensen gewend waren. Dit zou erop kunnen duiden dat herten juist mensen als een groter gevaar ervaren dan wolven (maar zie ook eerder besproken onderzoek van Atkins et al. (2019)). Recreatief gebruik van een gebied kan inderdaad leiden tot een verminderde bezoekfrequentie van hoefdieren en onderzoek van Brouwer (2020) toonde aan dat de vraat aan jonge bomen enigszins afneemt in de nabijheid van wandelpaden op de Veluwezoom. Het verschil in vraat was echter klein. Daarnaast kan ook gewenning optreden en kunnen dieren zich aanpassen aan drukbezochte gebieden, zoals Stillfried et al. (2017) aantoonden voor wilde zwijnen, die zich in de urbane omgeving van Berlijn hadden gevestigd. Ten slotte kan het verhogen van de recreatiedruk juist ook weer nadelige effecten veroorzaken aan andere natuurwaarden, met name voor verstoringsgevoelige broedvogels.

Verstoring van hoefdieren leidt vaak tot vluchtgedrag waarbij de vluchtafstand toeneemt in de volgorde mensen op/in voertuigen of te paard, voetgangers op paden en voetgangers buiten de paden (Stankowich, 2008). Bij voorspelbaar gedrag kan habituatie optreden en neemt de vluchtreactie af. Bejaagde populaties hebben een sterkere vluchtrespons dan niet-bejaagde populaties, vooral wanneer dieren mensen negatief associëren met de jacht. Bij frequente verstoring door jacht vertonen hoefdieren een groter vluchtgedrag, kunnen ze hun activiteitsgebied verkleinen of kunnen ze zelfs hun home range verlaten om zich te vestigen in een rustiger gebied (Stankowich, 2008; Keuling et al., 2008; Sodeikat \& Pohlmeyer, 2003). Vluchtgedrag van hoefdieren is groter in open habitat wanneer dekking ver weg ligt (Stankowich, 2008). In afschotvrije zones nemen de zichtbaarheid en dagactiviteit van hoefdieren daarom toe door het ontbreken van verstoring door de jacht naast een toename van de stand (FBP Gelderland; Russo et al., 1997; Stankowich, 2008).

Afleiden en verstoren bieden weinig perspectief op het verlagen van de wilddruk bij de huidige dichtheden. Er kan wel enige verschuiving plaatsvinden in activiteit van dieren, maar dit zal zich hoofdzakelijk beperken tot de periode overdag. Nachtelijke activiteit van dieren wordt er waarschijnlijk nauwelijks door beïnvloed (met uitzondering natuurlijk van nachtelijke bejaging, zie paragraaf 6.5). Indien de huidige leefgebieden kunnen worden uitgebreid met voedselrijkere habitats kan een deel van de populatie zich daar naartoe verplaatsen, zodat met gelijkblijvende aantallen de druk op huidige armere habitats verlicht wordt. Het is echter onzeker of dit de wilddruk tot het gewenste niveau zal verlagen. 


\subsection{Uitrasteren}

Door het omrasteren van kwetsbare habitats kan de wilddruk voor een bepaalde tijd tot vrijwel nul worden teruggebracht. $\mathrm{Er}$ is een overvloed aan bewijs dat dit de verjonging van loofboomsoorten en diversiteit in de verjonging sterk stimuleert (zie paragraaf 3.4). Er zijn verschillende soorten rasters beschikbaar, afhankelijk van de diersoorten die moeten worden tegengehouden. Voor het inscharen van runderen en paarden volstaan meestal enkele draden. Voor zwijnen is een laag raster voldoende, terwijl voor het uitsluiten van reeën, edelherten en damherten hoge rasters nodig zijn (tot $2 \mathrm{~m}$ ). Rasters kunnen bestaan uit gaas, schrikdraad of houten latten. Alle opties zijn evenwel duur en vormen een grote kostenpost voor het beheer.

Het grote voordeel van rasters is dat zij een hoge zekerheid bieden voor het uitsluiten van hoefdieren, mits goed onderhouden. Bovendien kunnen met rasters heel specifieke delen van terreinen worden beschermd tegen de effecten van hoefdieren. Kwetsbare boshabitats zouden in hun geheel voor een langere periode ingerasterd kunnen worden om een golf van verjonging teweeg te brengen. Ook zeer kwetsbare of zeldzame soorten zouden individueel ingerasterd kunnen worden, zoals nu gebeurt met de resterende populatie wilde appels in het Otterlose Bos. Na een geslaagde vestiging kunnen de rasters dan weer verwijderd worden en hoefdieren weer vrij toegang krijgen. In dit scenario is de hoogte van de wildstand irrelevant: binnen de exclosures is die altijd (nagenoeg) nul.

Tegelijkertijd vormen rasters een visuele obstructie in het boslandschap en doen daarmee afbreuk aan de belevingswaarde die ook nog lang kan doorwerken, doordat vaak zeer harde en rechte grenzen ontstaan tussen verschillende bosstructuren. Bij grotere oppervlakten worden niet alleen dieren, maar ook mensen uitgesloten. Het verkleint verder het beschikbare habitat voor hoefdieren zodat, bij gelijke wildstanden, de druk op het overige terrein toeneemt. Voorts geldt hier hetzelfde bezwaar als bij de gedifferentieerde jacht: het raster stimuleert de verjonging in een relatief klein gebied, terwijl de verjonging van boomsoorten in de rest van het bosgebied onder dezelfde druk blijft staan. Bovendien werken rasters sterk selectief in de ruimte: alleen binnen de rasters kan verjonging onbelemmerd opgroeien. Elders blijft de verjonging onderdrukt, zelfs wanneer de omstandigheden daartoe optimaal zijn.

Rasters moeten minstens 10-20 jaar blijven staan. Dat betekent dat, in het scenario dat bosverjonging over een termijn van 100 jaar gerealiseerd moet worden, 10-20\% van een gebied ingerasterd staat. Hierbij wordt dan aangenomen dat de verjonging binnen het raster overal optreedt. Dat zal alleen het geval zijn bij relatief kleine rasters op plekken waar de verjongingscondities gunstig zijn. Bij het inrasteren van grotere gebieden zal altijd een deel van het bos in een ontwikkelingsfase verkeren waarin nauwelijks tot geen verjonging zal optreden, omdat hiervoor de geschikte condities niet aanwezig zijn.

Het volledig uitsluiten van hoefdieren door rasters voorkomt ook dat zij hun positieve rol in het functioneren van het bosecosysteem kunnen vervullen. De verjonging van struiken en bomen zal, onder gunstige omstandigheden, snel ontstaan en binnen enkele jaren een grote dichtheid bereiken. Voor de minder concurrentiekrachtige soorten (zoals eik) zal dit een nadeel zijn. De snelle verdonkering van de bosbodem zal ook nadelig kunnen uitpakken voor aanwezige populaties (bijzondere) kwaliteitssoorten, met name de kruidachtigen. Dit is in lijn met de 'intermediate disturbance hypothesis' (Connell 1978), waarin wordt gesteld dat de hoogste diversiteit in een ecosysteem ontstaat bij een matig verstoringsregime. Geen verstoring, in dit geval het volledig uitsluiten van de verstorende invloed van hoefdieren, leidt dan evengoed tot een verlaging van de diversiteit als een hoge mate van verstoring bij hoge dichtheden. Enige invloed van hoefdieren blijft dus wenselijk. 


\section{Consequenties voor beheer}

\subsection{Uitgangspunten}

Als slotconclusie in het eerste deel van een driedelige reeks over het beheer van hoefdieren in Europa komen Apollonio et al. (2010) tot vier aanbevelingen:

1. Integreer in het wildbeheer alle belangen met betrekking tot landgebruik voor zover deze worden beïnvloed door hoefdieren. Dit betreft zowel het beheer van de hoefdierpopulaties zelf in het licht van regulatie van de populatieomvang, benutting of bescherming als hun impact op alle mogelijke beheerdoelen zoals landbouw, bosbouw, natuurbescherming en recreatie.

2. Formuleer heldere beheerdoelen (transparantie).

3. Implementeer wetenschappelijk gefundeerde monitoringprogramma's voor het volgen van trends in hoefdierpopulaties en hun effecten op het ecosysteem, zodat het beheer van hoefdieren daadwerkelijk kan worden geëvalueerd op effectiviteit en kan worden bepaald of beheerdoelen kunnen worden gerealiseerd.

4. Onderken expliciet de waarde van hoefdieren, zowel als levende organismen en onderdeel van de biodiversiteit in een gebied als een natuurlijke hulpbron die kan worden beheerd ter verbetering van het welzijn van de mensen in dat gebied.

Deze aanbevelingen zijn ook relevant voor de Nederlandse situatie (Groot Bruinderink \& Van der Grift, 2015; Van der Grift, 2018). Wanneer deze worden betrokken op de Veluwe moet allereerst worden vastgesteld dat de invloed van hoefdieren op de Natura 2000-boshabitattypen niet los kan worden gezien van de bredere landschappelijke context (zie paragraaf 2.4). De kwalificerende boshabitattypen liggen verspreid in relatief kleine eenheden over de Veluwe en worden omringd door, of liggen verweven met, overige niet-kwalificerende bostypen (Figuur 23). De leefgebieden van hoefdieren omspannen daardoor nooit uitsluitend kwalificerend habitat en eventuele wildbeheermaatregelen ten behoeve van kwalificerende habitat hebben altijd gevolgen voor de omliggende bostypen (en vice versa). Tegelijkertijd vormen omliggende bostypen een belangrijk reservoir voor (bijzondere) kwaliteitssoorten en zijn van belang voor uitbreiding van het areaal Natura 2000-boshabitattypen. Beheermaatregelen met betrekking tot hoefdieren moeten daarom breder geïmplementeerd worden dan alleen op het huidige areaal kwalificerende (bos)habitat.

Door de grote variatie aan eigenaars en binnen hun terreinen de variatie aan terreindoelen, lijkt het welhaast onmogelijk om tot gezamenlijke doelen te komen voor het beheer van hoefdierpopulaties in relatie tot de te realiseren kwaliteiten in de terreinen. Het formuleren van doelen in termen van 'natuurlijke processen' verhult vaak dat er wel degelijk impliciete doelen zijn ten aanzien van ontwikkelingen in de terreinen. Toch is er een groot gemeenschappelijk doel: op de Veluwe streven de meeste eigenaars en de grote terreinbeherende organisaties naar een bosontwikkeling richting een gevarieerd en gemengd bos dat wordt gedomineerd door loofboomsoorten (zie paragraaf 2.4). Deze doelen gelden voor zowel de Natura 2000-boshabitattypen als de niet-kwalificerende bostypen. Juist dit doel kan bij de huidige populatiegroottes van hoefdieren op de meeste delen van de Veluwe niet worden gerealiseerd.

Er wordt op de Veluwe nauwelijks gemonitord welke effecten hoefdieren hebben op de aanwezige ecosystemen. De enige serieuze monitoring richt zich op aanrijdingen en landbouwschade. Effecten op vegetatiestructuur en -samenstelling worden niet gemeten, behalve in de reeds acht jaar lopende vraatmonitoring in het Nationale Park Hoge Veluwe. De huidige sturing in populatiegroottes van hoefdieren op basis van telgegevens is ontoereikend om rekening te houden met variatie in terreingebruik door hoefdieren en variatie in de kwetsbaarheid van de vegetatie voor vraat of te realiseren terreindoelen. Beheer van hoefdierpopulaties zou veel meer gestuurd moeten worden op basis van hun effecten op de vegetatie. Adequate monitoring van effecten is dan cruciaal. Een dergelijke monitoring wordt ook door Gedeputeerde Staten Gelderland (2019) van belang geacht. 


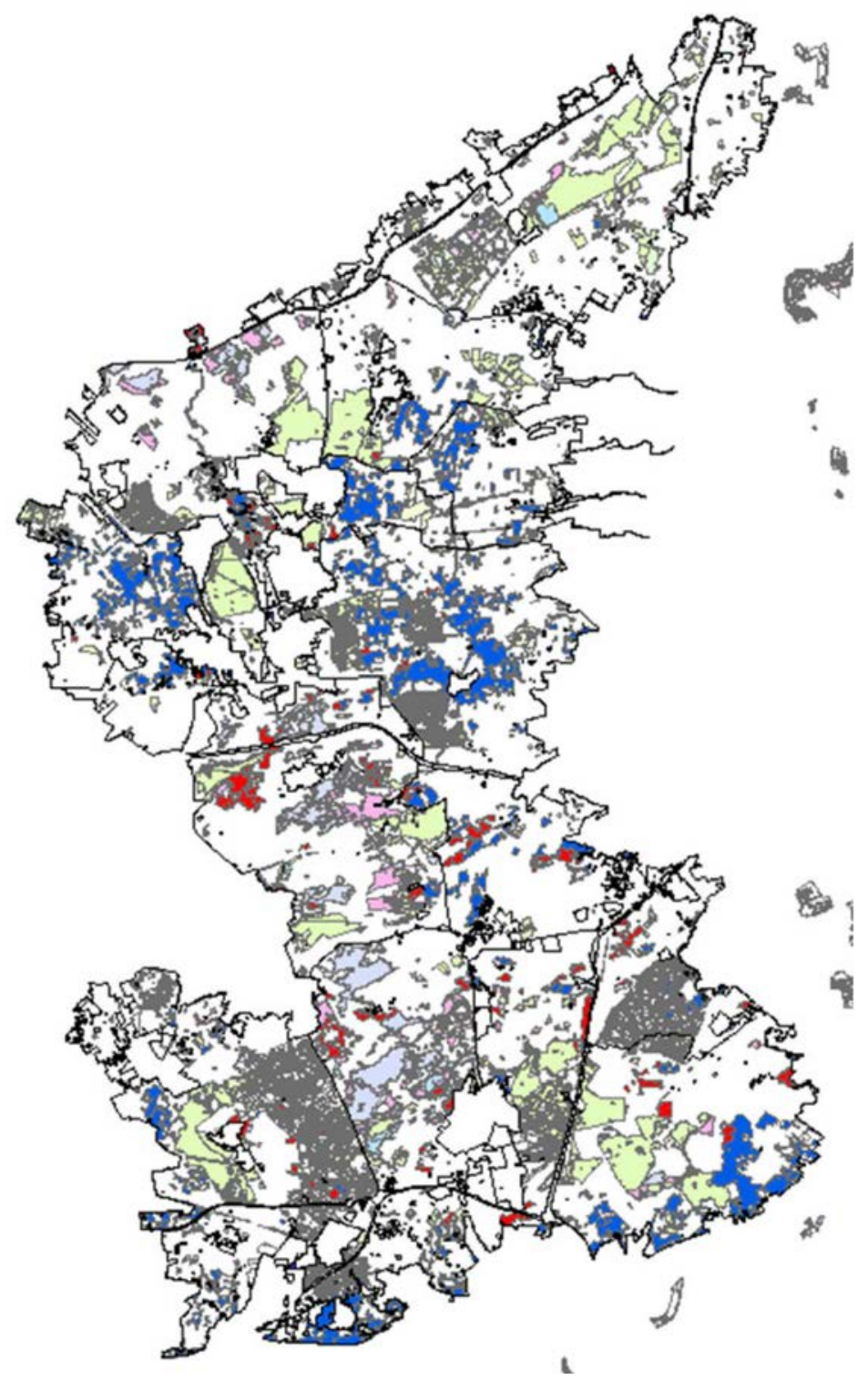

Figuur 23 Het voorkomen van Beuken-eikenbossen met hulst (H9120) (blauw) en Oude eikenbossen (H9190) (rood) op de Veluwe. Bron: Provincie Gelderland (2020).

Het belang voor de handhaving van levensvatbare populaties wilde hoefdieren op de Veluwe is evident. Zij vervullen een belangrijke ecologische rol en dragen in belangrijke mate bij aan de natuurbeleving van de bewoners en bezoekers van de Veluwe. Het populatiebeheer van wilde hoefdieren zal dus niet alleen afgestemd moeten worden op de effecten op ecosystemen, maar zal ook rekening moeten houden met de maatschappelijke wensen en gevoelens ten aanzien van wilde dieren.

Voor het behoud van de gewenste kwaliteiten van de boshabitattypen Beuken-eikenbos met hulst en Oude eikenbossen zal de invloed van hoefdieren in veel gevallen aanzienlijk moeten worden verlaagd. 


\subsection{Wildstanden en effecten op boshabitats}

Uit de literatuur is overduidelijk naar voren gekomen dat hoefdierpopulaties sturend zijn in de dichtheid en samenstelling van de bosverjonging en ondergroei. Bij toenemende dichtheden wordt een steeds groter deel van de verjonging aangevreten. Als eerste de smakelijkste soorten, zoals wilde lijsterbes en vuilboom, en naarmate de beschikbaarheid van smakelijke soorten afneemt, volgen de minder smakelijke soorten. Op enig moment zal alle verjonging van loofbomen worden belemmerd en resteren alleen nog naaldbomen (Figuur 11). Bij zeer hoge dichtheden zullen ook die worden gegeten. Op veel plekken op de Veluwe is de graasdruk al zo groot dat bij gebrek aan loofhout ook douglasspar, zilverspar en lariks worden aangevreten (zie paragraaf 3.2). Een hoge graasdruk leidt dan tot een sterke verarming van de boomflora en het verdwijnen van een struiklaag. In het vigerende Faunabeheerplan Grote Hoefdieren 2019-2025 (FBE Gelderland, 2019) wordt de hoge druk op de bosverjonging als een urgent probleem benoemd. De dominantie van vooral uitheemse naaldbomen in de verjonging en de belemmering van de verjonging van loofbomen, vormt op de langere termijn een bedreiging voor de instandhoudingsdoelen van de Natura 2000-boshabitattypen.

Verjonging van inheemse loofboomsoorten en het opgroeien van een gevarieerd gemengd bos zijn breed gedragen doelen voor de grote terreinbeherende organisaties op de Veluwe. Hoewel voor de beoordeling van de structuur en functie van de Natura 2000-boshabitattypen in het kader van de staat van instandhouding geen expliciete voorwaarden zijn gesteld, blijft verjonging van loofbomen op de langere termijn nodig voor het in stand houden van de boshabitats met de daaraan gekoppelde vegetatietypen en soorten. De provincie Gelderland heeft dit dan ook als expliciet doel geformuleerd voor de boshabitattypen op de Veluwe (zie Bijlage 1). Voor een voldoende mate van verjonging van alle bij de groeiplaats behorende inheemse loofboomsoorten in bostypen op (arme) zandgronden, is de literatuur verassend eenduidig over de dichtheden aan hoefdieren waarbij dit mogelijk is. Voor edelhert wordt hier een bovengrens van ongeveer 1-1,5 dier per 100 ha aangehouden. Voor alleen ree ligt de bovengrens in de orde van grootte 4 dieren per 100 ha. Deze getallen gelden voor afzonderlijke populaties, dus kunnen met betrekking tot deze bovengrenzen niet samen voorkomen. Voor wild zwijn worden in de literatuur nauwelijks getallen genoemd, maar op basis van Groot Bruinderink \& Hazebroek (1996) leidt een dichtheid van 2-4 dieren per 100 ha tot negatieve effecten op de verjonging. Ten overvloede moet hierbij worden vermeld dat lokaal nog lagere dichtheden noodzakelijk kunnen blijken voor het behalen van gewenste terreindoelen.

Over de relatie tussen hoefdierdichtheden en populaties (bijzondere) kwaliteitssoorten is nauwelijks informatie beschikbaar. Van de genoemde soorten lijken dalkruid en braam gevoelig voor een hogere graasdruk. Een hoge dichtheid van het wild zwijn leidt tot dermate grote en frequente bodemverstoring dat dit ten koste kan gaan van ter plekke aanwezige plantensoorten, zoals hengel, en bodemmossen en mycorrhizae-vormende paddenstoelen. Feitelijk worden bij intensieve bodemwoeling de meeste aanwezige generatief vermeerderende soorten vernietigd. De hazelworm heeft wellicht te lijden van directe predatie door wild zwijn. Voor overige soorten is nauwelijks informatie voorhanden, zijn de effecten niet aangetoond of naar verwachting klein. Het is niet mogelijk om voor deze soorten een bovengrens aan te geven in wilddruk om negatieve effecten op populatieniveau te voorkomen. Wel is duidelijk dat enige wilddruk gunstig is voor de diversiteit aan soorten in de ondergroei.

\subsection{Monitoring van hoefdieren en hun effecten}

De in de voorgaande paragraaf genoemde bovengrenzen voor aantallen hoefdieren suggereren dat die aantallen ook accuraat kunnen worden vastgesteld. Dat is maar ten dele waar. Bovendien zijn deze getallen gemiddelden over een groot areaal, terwijl effecten heel lokaal kunnen optreden. Verder is het niet altijd duidelijk binnen welke context effecten als 'negatief' worden beoordeeld: dat kan afhangen van verder niet gespecificeerde doelen zoals nagestreefde verjongingsdichtheden. Het aanhouden van dichtheden als sturend principe in het populatiebeheer levert daarom geen sterk fundament voor een beheer van hoefdieren dat is gericht op het voorkomen van ongewenste ecologische effecten. 
Een alternatief is het monitoren van die ecologische effecten zelf en op basis van een afwegingskader de noodzaak te bepalen tot ingrijpen. Dit opent de mogelijkheid om ingrepen in de hoefdierpopulatie op meer lokaal niveau af te stemmen op de daar geldende doelen en geconstateerde ecologische effecten. Een effectief monitoringsysteem dat zowel kijkt naar de effecten van beheer op de populatie grote hoefdieren als naar de impact die deze hebben op het (bos)ecosysteem, zou hierin een belangrijke rol kunnen spelen. Gevolgen van veranderingen in het wildbeheer kunnen dan gekoppeld worden aan veranderingen in de vegetatie en een zorgvuldige afweging van de resultaten kan dan helpen bij het maken van beslissingen.

In Frankrijk wordt hiertoe gebruikgemaakt van 'Indicators of Ecological Change (IEC)'. Dit is een set van relatief eenvoudig vast te stellen parameters waarmee zowel de conditie van de populaties grote hoefdieren wordt gemonitord als de toestand van de habitat (Morellet et al., 2007; Maublanc et al., 2016). In Duitsland worden effecten van hoefdieren al enige decennia systematisch gevolgd en wordt de noodzaak tot ingrijpen in de hoefdierpopulatie gebaseerd op het zogenaamde 'Forstliche Gutachten zur Situation der Waldverjüngung' (Bayerisches Staatsministerium für Ernährung, Landwirtschaft und Forsten, 2014). Op basis hiervan is voor de Veluwe een meetprotocol voorgesteld door Den Ouden et al. (2016) voor het volgen van effecten van graasdruk op de topvraat aan bosverjonging. Dit meetprotocol kan worden gecombineerd met inventarisaties van de verjongingsvoortgang van gewenste boomsoorten, populatieontwikkelingen van (bijzondere) kwaliteitssoorten, telgegevens en informatie over de conditie van dieren om zo tot een geïntegreerd monitoringsysteem te komen. Binnen dit monitoringsysteem kan gebruikgemaakt worden van verschillende indicatoren voor graasdruk (zie 5) om een inschatting te maken van de mate waarin effecten optreden in de vegetatieontwikkeling. De wilde lijsterbes lijkt een veelbelovende soort om hiervoor te gebruiken, zeker met betrekking tot verjongingsdoelen voor de twee boshabitattypen. $\mathrm{Er}$ is echter aanvullend onderzoek nodig om tot een praktisch toepasbaar monitoringsysteem te komen.

\subsection{Reguleren van wilddruk}

De huidige wildstand op de Veluwe is op de meeste plaatsen te hoog om de geformuleerde doelen te realiseren wat betreft de gewenste kwaliteiten van de Natura 2000-boshabitattypen. Dat leidt tot de vraag hoe de wilddruk op Beuken-eikenbossen met hulst en Oude eikenbossen in de praktijk kan worden verminderd opdat die doelen wel gerealiseerd kunnen worden. Bij de uitwerking van verschillende beheerscenario's in hoofdstuk 6 bleek dat een situatie zonder beheer van hoefdierpopulaties, al dan niet in aanwezigheid van grote predatoren, leidt tot nog hogere populatiedichtheden van hoefdieren dan in de huidige situatie. Ook maatregelen als het afweren en afleiden van hoefdieren zullen niet tot een structurele verlaging van de wilddruk leiden bij handhaving van de huidige standen. Exclosures (rasters) bieden wel een optimale bescherming, maar zijn te selectief in ruimtelijke zin, duur en verkleinen het areaal dat ter beschikking staat aan hoefdieren (zie paragraaf 6.7). Rasters kunnen wel een belangrijk hulpmiddel zijn om lokaal zeer kwetsbare vegetaties of soorten te beschermen.

Van de in dit rapport onderzochte scenario's lijken er dus slechts twee voor de hand te liggen om ongewenste effecten op de Natura 2000-boshabitats te voorkomen. De eerste is een generieke verlaging van de aantallen hoefdieren op de Veluwe (tot de in paragraaf 7.2 aangegeven dichtheden). Hierdoor worden de totale populatiegroottes, met name voor edelhert, echter wel flink lager dan de aantallen die nodig zijn voor het in stand houden van een minimale levensvatbare populatie (MVP; zie paragraaf 4.1). Op de korte termijn is dit waarschijnlijk geen probleem, maar bij een generieke verlaging van de aantallen hoefdieren is flankerend beleid nodig om problemen op langere termijn te voorkomen. Om voldoende genetische variatie te behouden, kan het totale leefgebied worden vergroot waardoor de totale populatiegrootte kan toenemen (bij gelijke of zelfs lagere dichtheden) en/of kan immigratie worden gefaciliteerd door verbinding van de Veluwe met omliggende populaties edelherten. Bij voortdurende isolatie van de Veluwse populatie edelherten kan ook overwogen worden om dieren van elders bij te plaatsen, al staat dit wel op gespannen voet met een meer natuurlijk populatiebeheer. 
Verder zal bij een generieke verlaging van de wildstand de wildzichtbaarheid afnemen. Om de wildzichtbaarheid te bevorderen, kunnen aanvullende maatregelen genomen worden, bijvoorbeeld door het inrichten van weinig kwetsbare gebieden als rustgebied met daarbij wildobservatiepunten. Tot slot zal onder dit scenario zeer waarschijnlijk aanvullend beheer nodig zijn, omdat de concurrentieverhoudingen tussen hoefdieren verschuiven. Door een lagere stand van edelherten en damherten neemt de hoeveelheid voedsel toe voor de andere hoefdiersoorten (met name ree), waardoor mogelijk extra afschot nodig zal zijn om ook de reeënpopulatie onder het benodigde niveau te houden.

Het grote voordeel van een generieke verlaging van de wildstand is dat verjonging van alle boomsoorten mogelijk wordt in alle bostypen. Hierdoor wordt het mogelijk alle bossen op termijn richting een gevarieerd loofbos te ontwikkelen en aan te vullen met ontbrekende loofboomsoorten (zie paragraaf 2.1.4). Hiermee zou ook de uitbreiding van het areaal kwalificerende Natura 2000boshabitattypen sterk worden gefaciliteerd.

Een tweede mogelijk scenario betreft maatwerk, dat wil zeggen differentiatie in het populatiebeheer van hoefdieren binnen de Veluwe. Immers, niet overal hoeft tegelijkertijd een lage wildstand te worden aangehouden. Het habitattype Beuken-eikenbossen met hulst is het kwetsbaarst voor een hoge wilddruk, maar komt niet over de gehele Veluwe voor: het concentreert zich vooral in het deel van de Veluwe boven de A1 en langs de Veluwezoom (Figuur 23). Overwogen kan dus worden om in wildbeheereenheden 3, 4, 5 en 10 (zie Figuur 24), of substantiële delen daarvan, een generieke verlaging van de wildstand te realiseren, met de bovengenoemde voor- en nadelen.

Schrikjacht - of ecologische jacht - kan een andere optie zijn. Hierbij wordt op nog kleinere schaal gevarieerd in jachtdruk ter vergroting van de verjongingsmogelijkheden. In theorie zou dit goed kunnen werken om lokaal de wilddruk sterk te verminderen, maar in de praktijk is hier nauwelijks nog ervaring mee opgedaan, dus zou het interessant zijn hiermee te gaan experimenteren. Daarbij staan nog veel vragen open, zoals de schaal in ruimte en in tijd waarop dit moet worden uitgevoerd en de organisatie hiervan. Bovendien staat daarmee de vraag nog open welke dichtheden buiten de intensief bejaagde zones worden gehandhaafd. Bij het aanhouden van de huidige stand zal in de resterende gebieden de ontwikkeling van gevarieerd loofbos nog steeds worden belemmerd.

Naast het verlagen van de wildstand is het aan te bevelen om geen rustgebieden te creëren in kwalificerende boshabitat of in de directe nabijheid daarvan, om te voorkomen dat deze als daginstand gaan fungeren. Sturing van het terreingebruik door een hogere verstoringsdruk door recreatie en jacht in deze boshabitats kan een aanvullend instrument zijn om de effecten van hoefdieren op de habitats te verminderen, maar daarvoor zal wel eerst een afweging moeten worden gemaakt of hiermee geen andere kwaliteiten van de habitat in het geding komen. Anderzijds moet de rust in aangewezen rustgebieden met voldoende toezicht gehandhaafd worden.

Ongeacht het scenario dat wordt gevolgd, blijft het cruciaal om niet zozeer te sturen op aantallen dieren, maar vooral op de effecten die hoefdieren uitoefenen op het ecosysteem. Daartoe zouden een gericht monitoringsnetwerk en een helder afwegingskader kunnen worden ontwikkeld als integraal onderdeel van het wildbeheer. Telgegevens blijven nuttig om trends in de populatiegroottes te kunnen volgen.

\subsection{Organisatie en draagvlak}

In het laatste deel van de driedelige reeks over hoefdieren in Europa eindigen Sykes \& Putman (2014) met de conclusie dat de "houding van mensen tegenover wilde dieren even sterk, zo niet sterker, wordt bepaald door sociale en culturele ideologie als door omgevingsfactoren, hetgeen in ogenschouw moet worden genomen bij het ontwikkelen van beheerregimes van hoefdieren". 


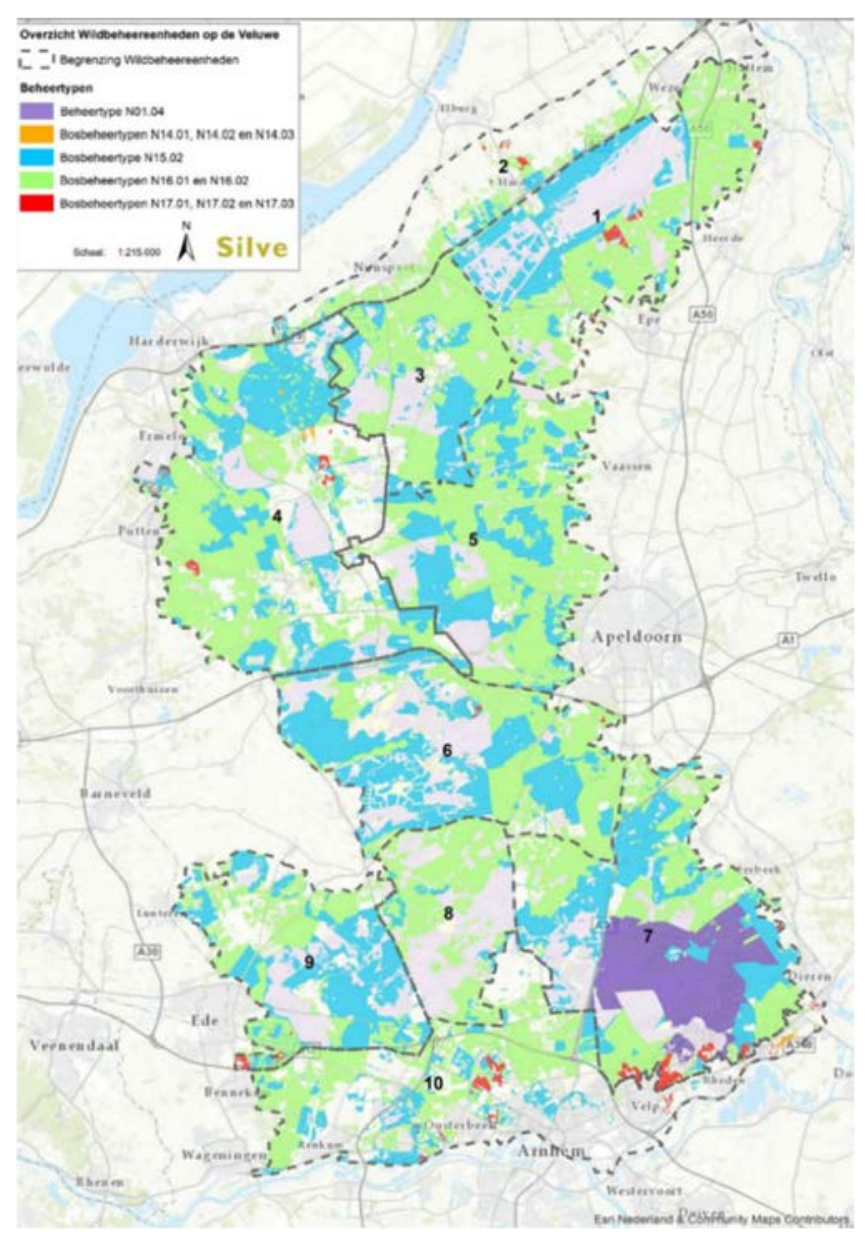

Figuur 24 Overzicht van de tien wildbeheereenheden op de Veluwe. Figuur overgenomen uit Den Ouden et al. (2016).

Voor de Natura 2000-boshabitattypen, en voor een groot deel van de overige bossen op de Veluwe, is verlaging van de wilddruk een belangrijke voorwaarde om de geformuleerde doelen en gewenste kwaliteiten te kunnen realiseren (Gedeputeerde Staten Gelderland, 2019; FBE Gelderland, 2019). Tegelijkertijd vraagt de levensvatbaarheid van populaties hoefdieren, met name edelhert, om verhoging van de stand. Maatschappelijk speelt de wens om veel wild te zien en wordt een steeds sterker gepolariseerd debat gevoerd rondom het al dan niet mogen ingrijpen in populaties hoefdieren. Het ontwarren van deze gordiaanse knoop vereist een zorgvuldig beleid en een professionele uitvoering daarvan.

Voor het populatiebeheer van hoefdieren is het essentieel dat de gestelde doelen, voor zowel dichtheden als effecten, ook daadwerkelijk worden gerealiseerd. Dit vereist een heldere regie bij het te realiseren afschot om te zorgen dat de lijn van afgelopen jaren, waarbij in veel WBE's de aantallen hoefdieren de vastgestelde doelstanden structureel overstegen, niet wordt voortgezet (zie paragraaf 6.3). Ook in de uitvoering lijkt het afschot zich nogal eens te richten op gewenste prooien/trofeeën en niet zozeer op een efficiënte reductie van de populatie. Dit maakt duidelijk dat niet in alle deelgebieden het beheer naar behoren verloopt. In Groot Bruinderink \& Van der Grift (2015) en Van der Grift (2018) wordt al aangegeven dat het faunabeheer in Nederland niet goed op orde is en dat de wetenschap onvoldoende wordt benut. Dit maakt het beleid kwetsbaar voor kritiek.

Maatschappelijke verantwoording voor de regulering van de wildstand is essentieel voor het welslagen van benodigd beleid en daaruit voortvloeiende maatregelen. Nu het faunabeheerplan zich niet alleen op landbouw- en verkeersschade richt maar ook de ecologische effecten expliciet meeweegt, zullen doelstelling en uitvoering van het faunabeheer zich veel meer moeten baseren op gedetailleerde informatie omtrent het terreingebruik en gedrag van de hoefdieren op de Veluwe en op monitoring van de effecten. Dit vraagt om heldere doelen en keuzes en om een professionele uitvoering. 


\section{Conclusies}

In dit rapport is op hoofdlijnen antwoord gezocht op de onderstaande kernvragen:

1. Wat is de wilddruk waarbij natuurlijke verjonging van bij Natura 2000-boshabitattypen behorende boom- en struiksoorten nog van de grond komt?

2. Welk wildbeheer is gewenst om de Natura 2000-boshabitattypen in stand te houden?

De huidige populaties hoefdieren zijn op grote delen van de Veluwe te groot voor het realiseren van de geformuleerde terreindoelen. Specifiek met betrekking tot Natura 2000-habitattypen Beuken-eikenbossen met hulst en Oude eikenbossen leidt de huidige wilddruk in veel gevallen tot het uitblijven van de gewenste verjonging van het volledige palet aan loofboomsoorten die op de verschillende groeiplaatsen zouden kunnen voorkomen, met onder meer een sterke toename van exoten als gevolg. Ook populaties van een aantal (bijzondere) kwaliteitssoorten en typische soorten van de boshabitattypen worden onder de huidige wilddruk ongunstig beïnvloed, maar in welke mate dit gebeurt, is nog onvoldoende onderzocht. Op de korte termijn leidt dit tot kwaliteitsverlies van de betreffende habitats en de omringende bossen. Op de lange termijn heeft dit een negatief effect op de staat van instandhouding van de huidige boshabitattypen en wordt uitbreiding van kwalificerende boshabitattypen belemmerd.

Voor het verkrijgen van een voldoende mate van verjonging van alle bij de groeiplaats behorende inheemse loofboomsoorten, de ontwikkeling van een nieuwe bosgeneratie met een diverse boomsoortensamenstelling en het behoud van (bijzondere) kwaliteitssoorten en typische soorten in levensvatbare populaties, is een verlaging van de wilddruk noodzakelijk. Uit de literatuur komt naar voren dat voor de bosverjonging de dichtheid niet hoger mag zijn dan ordegrootten van 1-1,5 edelhert per 100 ha, 4 ree per $100 \mathrm{~h}$ en 2-4 wild zwijn per 100 ha. Echter, sturing op aantallen is weinig effectief vanwege problemen bij het vaststellen van werkelijke aantallen, variatie in terreingebruik binnen leefgebieden, variatie in habitats en de relatief kleine schaal waarop habitattypen in het landschap voorkomen. Populatiebeheer van hoefdieren zou beter afgestemd kunnen worden op de ecologische effecten die direct in de terreinen kunnen worden waargenomen. Dit rapport geeft daartoe enkele handreikingen. Nader onderzoek is nodig voor het vaststellen van de geschiktste manier van monitoring en de daarbij op te nemen indicatoren.

Voor het verlagen van de wilddruk komen twee algemene opties in aanmerking: een generieke standsverlaging of een meer gedifferentieerde aanpak waarbij de wilddruk lokaal of regionaal wordt verlaagd. In beide gevallen is afschot het gebruikte middel. Zeer kwetsbare vegetaties of populaties kunnen op kleine schaal beschermd worden via rasters. Als algemene maatregel is rasteren niet gewenst. Bij een generieke standsverlaging kunnen naast de kwalificerende boshabitattypen ook de overige bosgebieden in kwaliteit toenemen. Tevens wordt hiermee het perspectief vergroot op uitbreiding van de boshabitattypen.

Verlaging van de standen van grote hoefdieren, met name edelhert en wild zwijn, moet gepaard gaan met flankerende maatregelen om een duurzaam behoud te garanderen van aanwezige populaties. Het faciliteren van uitwisselingsmogelijkheden met gebieden buiten de Veluwe is daarbij het effectiefst. Via een slimme inrichting van rustgebieden en wildobservatieplaatsen kan de wildzichtbaarheid op peil worden gehouden. Dit alles vraagt om een sterke coördinatie en regie vanuit de provincie en de Faunabeheereenheid en een verdere professionalisering in de uitvoering. Voor het evalueren van de effectiviteit van beheer is ook hier een monitoring op ecologische effecten gewenst. 


\section{Literatuur}

Adrados, C., C. Baltzinger, G. Janeau \& D. Pepin 2008. Red deer Cervus elaphus resting place characteristics obtained from differential GPS data in a forest habitat. Eur. J. Wildl. Res. 54: 487-494.

Anderson, R.C., 1994. Height of White-Flowered Trillium (Trillium grandiflorum) as an Index of Deer Browsing Intensity. Ecological Applications 4: 104-109.

Anderson-Teixera, K.J., S.J. Davies et al., 2014. CTFS-ForestGEO: a worldwide network monitoring forests in an era of global change. Global Change Biology (2014).

Apollonio, M., R. Andersen \& R. Putman, 2010. Present status ad future challenges for European ungulate management. In: European ungulates and their management in the $21^{\text {st }}$ century. Edited by M. Apollonio, R. Andersen \& R. Putman. Cambridge University Press, Cambridge, pp. 578-604.

Apollonio, M., R. Putman, S. Grignolio \& L. Bartoš, 2011. Hunting seasons in relation to biological breeding seasons and the implications for the control or regulation of ungulate populations. In: Ungulate management in Europe. Problems and practices. Edited by R. Putman, M. Apollonio \& R. Andersen. Cambridge University Press, Cambridge, pp. 80-105.

Arcese, P., R. Schuster, L. Campbell, A. Barber \& T. G. Martin, 2014. Deer density and plant palatability predict shrub cover, richness, diversity and aboriginal food value in a North American archipelago. Diversity and Distributions 20, 1368-1378.

Arnold, J.M., P. Gerhardt, S.M.J.G. Steyaert, E. Hochbichler \& K. Hackländer, 2018. Diversionary feeding can reduce red deer habitat selection pressure on vulnerable forest stands, but is not a panacea for red deer damage. Forest Ecology and Management 407: 166-173.

Atkins, J.L., R.A. Long, J. Pansu, J. H. Daskin, A.B. Potter, M. E. Stalmans, C. E. Tarnita \& R. M. Pringle, 2019. Cascading impacts of large-carnivore extirpation in an African ecosystem. Science 364: 173-177.

Baker, K.H., H.W.I. Gray, V. Ramovs, D. Mertzanidou, C.A. Peksen, C.C. Bilgin, N. Sykes \& A.R. Hoelzel, 2017. Strong population structure in a species manipulated by humans since the Neolithic: the European fallow deer (Dama dama dama). Heredity 119: 16-26.

Baptist, M., T. van Hattum, S. Reinhard, M. van Buuren, B. de Rooij, X. Hu, S. van Rooij, N. Polman, S. van den Burg, G. Piet, T. Ysebaert, B. Walles, J. Veraart, W. Wamelink, B. Bregman, B. Bos \& T. Selnes, 2019. A nature-based future for the Netherlands in 2120 . Wageningen University and Research, Wageningen.

Barrios-Garcia, M.N. \& S.A. Ballari, 2012. Impact of wild boar (Sus scrofa) in its introduced and native range: a review. Biological Invasions 14: 2283-2300.

Bayerisches Staatsministerium für Ernährung, Landwirtschaft und Forsten, 2014. Anweisung für die Erstellung der Forstlichen Gutachten zur Situation der Waldverjüngung.

Bijlsma, R.J., J.A.M. Jansen, R. Haveman, R.W. de Waal \& E. Weeda, 2008. Natura 2000 habitattypen in Gelderland. Wageningen, Alterra, Alterra rapport 1769.

Bijlsma, R.-J., J. den Ouden. \& H. Siebel, 2009. Oude eikenbossen: nieuwe inzichten en kansen. De Levende Natuur 110: 77-82.

Blossey, B. P. Curtis, J. Boulanger \& A. Dávalos, 2019. Red oak seedlings as indicators of deer browse pressure: Gauging the outcome of different white-tailed deer management approaches. Ecology and Evolution 9:13085-13103.

Bobbink, R., H.L.T. Bergsma, J. den Ouden \& M.J. Weijters, 2017. Na het zuur geen zoet: bodemverzuring een blijvend probleem in het droog zandlandschap. Landschap 34: 60-69.

Bobiec, A., A. Reif \& K. Öllerer, 2018. Seeing the oakscape beyond the forest: a landscape approach to the oak regeneration in Europe. Landscape Ecology 33: 513-528.

Bobrowski, M., B. Gillich \& C. Stolter, 2015. Modelling browsing of deer on beech and birch in northern Germany. Forest Ecology and Management 358: 212-221.

Boiko, S., E. Bielinis, Z. Sierota, A. Zawadzka, M. Nasiadko \& J. Borkowski, 2019. Changes in lower layers biodiversity caused by Polish pony in old growth Scots pine stands. Preprints 2019, 2019030204.

Bokdam, J., 2003. Nature conservation and grazing management. Free-ranging cattle as a driving force for cyclic vegetation succession. Dissertatie, Wageningen University, Wageningen. 
Bonnet, T., M. B. Morrissey, A. Morris, S. Morris, T.H. Clutton-Brock, J. M. Pemberton \& L.E.B. Kruuk, 2019. The role of selection and evolution in changing parturition date in a red deer population. PLOS Biology 3000493.

Borowski, S. \& S. Kossak, 1972. The natural food preferences of the European bison in seasons free of snow cover. Acta Theriologica 17: 151-169.

Van den Broek, W. 2015. Spatial and temporal habitat selection by Red Deer (Cervus elaphus) in De Hoge Veluwe, National Park. MSc thesis, Wageningen University, Wageningen.

Briedermann, L., 2009. Schwarzwild. Kosmos Verlag, Stuttgart.

Broekhuizen, S., K. Spoelstra, J.B.M. Thissen, K.J. Canters and J.C. Buys (redactie), 2016. Atlas van de Nederlandse zoogdieren. Natuur in Nederland 12. Naturalis Biodiversity Centre and EIS Kenniscentrum Leiden.

Brown, J.S., J.W. Laundré \& M. Gurung, 1999. The ecology of fear: optimal foraging, game theory, and trophic interactions. Journal of Mammology 80: 385-399.

Brouwer, K., 2020. De invloed van mensen op het graasgedrag van herten. De Levende Natuur 121: 30-31.

Brouwers, N.C., 2004. The relation between deer density and browsing damage. MSc thesis Wageningen University, Wageningen.

Burney O.T. \& D.F. Jacobs, 2013. Ungulate herbivory of boreal and temperate forest regeneration in relation to seedling mineral nutrition and secondary metabolites. New Forests 44:753-768.

Buttenschøn, R.M. \& J. Buttenschøn, 2013. Woodland grazing with cattle - results from 25 years of grazing in acidophilus pedunculate oak (Quercus robur). In: I.D. Rotherham (ed). Trees, forested landscapes and grazing animals. Taylor Francis, London.

Chevrier, T., S. Saïd, O. Widmer, J.P. Hamard, C. Saint-Andrieux \& J.M. Gaillard, 2012. The oak browsing index correlates linearly with roe deer density: a new indicator for deer management? European Journal Wildlife Research 58:17-22.

Clutton-Brock, T.H, F.E. Guinness \& S.D. Albon, 1982. Red deer; the behaviour and ecology of two sexes. University of Chicago Press.

Clutton-Brock, T.H., O.F. Price, S.D. Albon \& P.A. Jewell, 1992. Early development and population fluctuations in Soay sheep. Journal of Animal Ecology 64: 381-396.

Connell, J.H., 1978. Diversity in tropical rain forests and coral reefs". Science 199: 1302-1310.

Cornelissen, P., 2017. Large herbivores as a driving force of woodland-grassland cycles. The mutual interactions between the population dynamics of large herbivores and vegetation development in a eutrophic wetland. Dissertatie, Wageningen University, Wageningen.

Cornelissen, P., J. Bokdam, K. Sykora \& F. Berendse, 2014a. Effects of large herbivores on wood pasture dynamics in a European wetland system. Basic and Applied Ecology. 15:396-406.

Cornelissen, P., M.C. Gresnigt, R.A. Vermeulen, J. Bokdam \& R. Smit, 2014b. Transition of a Sambucus nigra L. dominated woody vegetation into grassland by a multi-species herbivore assemblage. Journal for Nature Conservation 22: 84-92.

Côté, S.D., T.P. Rooney, J.P. Tremblay, C. Dussault \& D.M. Waller, 2004. Ecological impacts of deer overabundance. Annual Review of Ecology, Evolution and Systematics 35: 113-147.

Creel, S. \& D. Christianson, 2008. Relationships between direct predation and risk effects. Trends in Ecology and Evolution, 23, 194- 201.

Cromsigt, J.P.G.M. \& D.P.J. Kuiper, 2018. Niet tellen, maar sturen. Faunabeheer gericht op gedragsverandering. Vakblad Natuur, Bos \& Landschap, November 2018: 24-27.

Cromsigt, J.P.G.M., D.P.J. Kuijper, M. Adam, R.L. Beschta, M. Churski, A. Eycott, G.I.H. Kerley, A. Mysterud, K. Schmidt \& K. West, 2013. Hunting for fear: innovating management of humanwildlife conflicts. Journal of Applied Ecology 50: 544-549.

Desie, E., K. Vancampenhout, B. Nyssen, L. van den Berg, M. Weijters, G.-J. van Duinen, J. den Ouden, K. Van Meerbeek \& B. Muys, 2020. Litter quality and the law of the most limiting: Opportunities for restoring nutrient cycles in acidified forest soils. Science of the Total Environment 699 (2020) 134383.

Dobrowolska, D., D. Załuski, W. Dąbrowski, R. Banul \& J. Borkowski, 2020. Factors affecting admixed pedunculate oak growth under heavy browsing by deer: benefits from inter- and intraspecific neighbourhoods. European Journal of Forest Research 2020.

Van Dongen, B.B.C.A.D.,2005. De relatie tussen reeën dichtheden (Capreolus capreolus), recreatiedruk en vraatschade aan natuurlijke verjonging. MSc-thesis Wageningen University, Wageningen. 
Estes, J., J. Terborgh, J. Brashares, M. Power \& J. Berger, 2011. Trophic downgrading of planet Earth. Science 333, 301-306.

European Environmental Agency, 2019. Report art 17 Habitat Directive. URL: https://cdr.eionet.europa.eu/nl/eu/art17/envxuhrwa/NL_habitats_reports20190819.xml/manage_document. Geraadpleegd februari 2020.

Europese Commissie, 2013. Interpretation manual of European Union habitats. European Commission, DG Environment, Nature ENV B.3.

FBE (Faunabeheereenheid) Gelderland, 2019. Faunabeheerplan Grote Hoefdieren 2019-2025. Faunabeheereenheid Gelderland, Deventer.

Fehér, A., L. Szemethy \& K. Katona, 2016. Selective debarking by ungulates in temperate deciduous forests: preference towards tree species and stem girth. European Journal of Forest Research 135: 1131-1143.

Fløjgaard, C., M. De Barba, P. Taberlet \& R. Ejrnæs, 2017. Body condition, diet and ecosystem function of red deer (Cervus elaphus) in a fenced nature reserve. Global Ecology and Conservation 11: 312-323.

Frerker, K., G. Sonnier \& D.M. Waller, 2013. Browsing rates and ratios provide reliable indices of ungulate impacts on forest plant communities. Forest Ecology and Management 291: 55-64.

Gebert, C. \& H. Verheyden-Tixier, 2008. Variations of diet composition of red deer (Cervus elaphus L.) in Europe. Mammal Review 31: 189-201.

Gebczynska, Z, M Gebczynski \& E. Martynowicz, 1991. Food eaten by the free-living European bison in Bialowieza forest. Acta Theriologica 36: 307-313.

Gedeputeerde Staten Gelderland, 2019. Uitvoeringskader Fauna Gelderland. Zaaknummer 20170031940. Provincie Gelderland, Arnhem.

Geldersch Landschap \& Kasteelen, ongedat. Nota bosbeleid 2017-2026. GLK, Arnhem.

Gill, R.M.A., 1992a. A review of damage by mammals in north temperate forests: 1 . Deer. Forestry 65: $145-169$.

Gill, R.M.A., 1992b. A review of damage by mammals in north temperate forests: 3. Impacts on trees and forests. Forestry 65: 363-388.

Gill, R., 1994. The population dynamics of roe deer (Capreolus capreolus L.) in relation to forest habitat succession. Dissertation, The Open University, Milton Keynes, United Kingdom.

Gill, R.M.A., J. Webber \& A. Peace, 2000. The economic implications of deer damage. A review of current evidence. Forest Research Agency, Wrecclesham, V.K. 49 pp.

Gill, R.M.A. \& V. Beardall, 2001. Impact of deer on vegetation structure and composition. Forestry 74 : 209-218.

Gill, R.M.A. \& G. Morgan, 2010. The effects of varying deer density on natural regeneration in woodlands in lowland Britain. Forestry 83: 53-63.

van Ginkel, H.A.L., 2020. Wolves, tree logs and tree regeneration. Combined effects of downed wood and wolves on the regeneration of palatable and less palatable tree species. Dissertatie, Rijksuniversiteit Groningen, Groningen.

van Ginkel, H.A.L., D.P.J. Kuijper, J. Schotanus \& C. Smit, 2019a. Wolves and Tree Logs: LandscapeScale and Fine-Scale Risk Factors Interactively Influence Tree Regeneration. Ecosystems 22: 202-212.

van Ginkel, H.A.L., C. Smit \& D.P.J. Kuijper, 2019b. Behavioral response of naïve and non-naïve deer to wolf urine. PLOS ONE 14(11): e0223248.

Gordon I.J. \& H.H.T. Prins, 2019. Browsers and grazers drive the dynamics of ecosystems. In: I.J. Gordon \& H.H.T. Prins (eds). The ecology of browsing and grazing II. Ecological Studies 239. Springer Nature Switzerland.

Goudzwaard, L., H.H. Bartelink \& H.G.J.M. Koop, 2001. Effecten van dunning en vraat op spontane verjonging in eiken-dennenbossen. Alterra rapport 269, Wageningen Universiteit, Wageningen.

van der Grift, E., 2018. Faunabeheer: waar is de wetenschap? Vakblad Natuur Bos Landschap, 149: 4-7.

van der Grift, E., A. Schotman, H. Jansman \& G. A. de Groot, 2018. Uitplaatsing van grote grazers uit de Oostvaardersplassen: Een quickscan van potentiële uitzetgebieden. WENR rapport 2903. Wageningen Environmental Research, Wageningen.

de Groot, G.A., H.A.H. Jansman, J. Bovenschen, I. Laros, Y. Meyer-Lucht \& J. Höglund, 2014. Inteelt onder Sallandse korhoenders; De genetische gevolgen van een kleine populatieomvang. Alterrarapport 2599. Wageningen University \& Research, Wageningen. 
de Groot, G.A., G.J. Spek, J. Bovenschen, I. Laros, T. van Meel \& H.A.H. Jansman, 2016. Herkomst en migratie van Nederlandse edelherten en wilde zwijnen: een basiskaart van de genetische patronen in Nederland en omgeving. Alterra-rapport 2724, Alterra, Wageningen.

Groot Bruinderink, G.W.T.A. \& E. Hazebroek, 1994. Diet and condition of wild boar, Sus scrofa scrofa, without supplementary feeding. J. Zool. Lond. 233: 631-648.

Groot Bruinderink, G.W.T.A. \& E. Hazebroek, 1995. Ingestion and diet composition of red deer (Cervus elaphus L.) in the Netherlands from 1954 till 1992. Mammalia 59(2): 187-195.

Groot Bruinderink, G.W.T.A. \& E. Hazebroek. 1996. Wild boar (Sus scrofa L.) rooting and forest regeneration on podzolic soils in the Netherlands. Forest Ecology and Management 88 71-80.

Groot Bruinderink, G.W.T.A., E. Hazebroek \& H. van der Voet, 1997a. Wroeten door het wilde zwijn en de gevolgen voor bodem en bosverjonging. In: Wieren, S.E., van, Groot Bruinderink, G.W.T.A., Jorritsma, I.T.M. and Kuiters, A.T. (eds) Hoefdieren in het boslandschap. Backhuys Publishers, Leiden, pp. 131-145.

Groot Bruinderink, G.W.T.A., S.E. van Wieren, E. Hazebroek, M.H. den Boer, F.J.M. Maaskamp, W. Lamers, P.A. Slim \& C.B. de Jong, 1997b. De ecologie van hoefdieren. In: Wieren, S.E., van, Groot Bruinderink, G.W.T.A., Jorritsma, I.T.M. and Kuiters, A.T. (eds) Hoefdieren in het boslandschap. Backhuys Publishers, Leiden, pp. 131-145.

Groot Bruinderink, G.W.T.A., A.T. Kuiters \& D.R. Lammertsma, 1998. Geïntegreerd bosbeheer en grofwild. Nederlands Bosbouwtijdschrift 70: 50-58.

Groot Bruinderink, G.W.T.A. \& D.R. Lammertsma, 2001. Terreingebruik en gedrag van runderen, pony's, edelherten, reeën en wilde zwijnen in het Nationaal Park Veluwezoom van de Vereniging Natuurmonumenten. Wageningen, Alterra, Research Instituut voor de Groene Ruimte. Alterrarapport 343.

Groot Bruinderink, G., T. van der Sluis, D. Lammertsma, P. Opdam \& R. Pouwels, 2003. Designing a coherent ecological network for large mammals in Northwestern Europe. Conservation Biology 17: $1-10$.

Groot Bruinderink, G.W.T.A., R.J. Bijlsma, J. den Ouden, C.A. van den Berg, A.J. Griffioen, I.T.M. Jorritsma, R. Kluiver, K. Kramer, A.T. Kuiters, D.R. Lammertsma, H.H.T. Prins, G.J. Spek \& S.E. van Wieren, 2004. De relatie tussen bosontwikkeling op de Zuidoost Veluwe en de aantallen edelherten, damherten, reeën, wilde zwijnen, runderen en paarden. Onderzoek naar de realisatiemogelijkheid van beheerdoelstellingen. Alterra, Wageningen.

Groot Bruinderink, G.W.T.A., D.R. Lammertsma, G.A.J.M. Jagers op Akkerhuis, W. Ozinga, A.H.P. Stumpel. J.M. Baveco \& R.W. de Waal, 2009. Ex ante evaluatie van maatwerk beheer van wilde zwijnen. Alterra-rapport 1944, Wageningen.

Groot Bruinderink, G.W.T.A., H.A.H. Jansman, M.H. Jacobs \& M. Harmsen, 2011. De komst van de wolf (Canis lupus) in Nederland: een 'factfinding study'. Alterra-rapport 2339, Alterra, Wageningen.

Groot Bruinderink, G, D. Lammertsma \& B. Worm, 2012. De mineralenstatus van edelherten in Nederland. Het Edelhert, zomer 2012: 24-29.

Groot-Bruinderink, G.W.T.A., P.W. Goedhart, D.R. Lammertsma \& J.J.A. Dekker, $2013 a$. Schadeveroorzakende zoogdiersoorten in Nederland. Alterra rapport 2426, Alterra, Wageningen.

Groot Bruinderink, G.W.T.A., D.R. Lammertsma \& A.T. Kuiters, 2013b. Hoeveel damherten en reeën kunnen leven in de Amsterdamse Waterleidingduinen op basis van het natuurlijk voedselaanbod? Alterra notitie.

Groot Bruinderink, G.W.T.A. \& E. van der Grift, 2015. Faunabeheer van wilde hoefdieren: nog niet goed op orde. Vakblad Natuur Bos Landschap, 120: 26-29.

Hacke-Oudemans, J.J., 1969. Bijdragen tot de geschiedenis van de Veluwe en andere onderwerpen. Callenbach, Nijkerk.

Harmer, R., 2001. The effect of plant competition and simulated summer browsing by deer on tree regeneration. Journal of Applied Ecology 38: 1094-1103.

Healy, W.M., D.S. deCalesta, \& S.L. Stout, 1997. A research perspective on white-tailed deer overabundance in the northeastern United States. Wildlife Society Bulletin 25: 259-263.

Heroldova, M., 1996. Dietary overlap of three ungulate species in the Palava biosphere reserve. Forest Ecology and Management 88: 139-142.

Hobbs, R.J., E.S. Higgs \& C.M. Hall, 2013. Novel Ecosystems: Intervening in the New Ecological World Order. John Wiley \& Sons. 
Hofmeester, T. R., H. Sprong, P.A. Jansen, H.H. Prins \& S.E. van Wieren, 2017. Deer presence rather than abundance determines the population density of the sheep tick, Ixodes ricinus, in Dutch forests. Parasites \& Vectors, 10, 433.

Hofmann, R. R., 1989. Evolutionary steps of ecophysical adaptation and diversification of ruminants: A comparative view of their digestive system. Oecologia 78:443-457.

Hommel, P., R. de Waal, B. Muys, J. den Ouden \& Th. Spek, 2007. Terug naar het lindenwoud. Strooiselkwaliteit als basis voor ecologisch bosbeheer. KNNV Uitgeverij, Zeist.

Hopcraft, J.G.C., H. Olff \& A.R.E. Sinclair, 2010. Herbivores, resources and risks: alternating regulation along primary environmental gradients in savannas. Trends in Ecology \& Evolution 25:119-128.

Horst, M. 2011. Van hout delen naar aandelen; Landschap, organisatie en beheer van de maalschap van het Gortelsche Bos op de Noordoost-Veluwe - 1618-1907. MSc scriptie, Rijksuniversiteit Groningen, Groningen.

Howells, O. \& G. Edwards-Jones, 1997. A feasibility study of reintroducing wild boar Sus scrofa to Scotland: Are existing woodlands large enough to support minimum viable populations. Biological Conservation 81: 77-89.

Huysentruyt F. \& J. Casaer, 2015. Experiment Deelerwoud. Evaluatie verzamelde gegevens 2001-2014 ter voorbereiding van het evaluatierapport. Rapporten van het Instituut voor Natuur- en Bosonderzoek 2015 (INBO.R.2015.9092053). Instituut voor Natuur- en Bosonderzoek, Brussel.

Janssen, J., R.-J. Bijlsma, G. Arts, M. Baptist, S. Hennekens, B. de Knegt, T. van der Meij, J. Schaminée, A. van Strien, S. Wijnhoven \& T. Ysebaert, 2020. Habitatrichtlijnrapportage 2019: Annex D Habitattypen. Achtergronddocument. Wettelijke Onderzoekstaken Natuur \& Milieu, technical report 171 .

Jedrzejewski, W, H. Spaedtke, J.F. Kamler, B. Jedrzejewska \& U. Stenkewiz, 2006. Group size dynamics of red deer in Bialowieza Primeval Forest, Poland. Journal of Wildlife Management 70 : 1054- 1059.

Jedrzejewski W., B. Jedrzejewska, Z. Andersone-Lilley, L. Balciauskas, P. Mannil, J. Ozolins, V.E. Sidorovich, G. Bagrade, M. Kubarsepp, A. Ornicans, S. Nowak, A. Pupila \& A. Zunna, 2010. Synthesizing wolf ecology and management in Eastern Europe: similarities and contrasts with North America. In: Musiani, M., L. Boitani \& P.C. Paquet (2010). The world of wolves. New perspectives on ecology, behaviour and management, pp. 207-233. University of Calgary Press, Calgary.

Jong, C.B. de, 2000. Voedselkeus van reeën, damherten en konijnen in de Manteling van Walcheren. Intern rapport, Wageningen Universiteit, Wageningen.

Jong, J.F. de, 2018. Genetic variation of wildlife in a human-dominated landscape: Genome-wide SNP analysis of wild boar (Sus scrofa) en red deer (Cervus elaphus) from the European continent. Dissertatie, Wageningen University, Wageningen.

Jongmans, A.G., M.W. van den Berg, M.P.W. Sonneveld, G.J.W.C. Peek \& R.M. van den Berg van Saparoea, 2013. Landschappen van Nederland. Geologie, bodem en landgebruik. Wageningen Academic Publishers, Wageningen.

Jorritsma, I.T.M., G.M.J. Mohren, S.E. van Wieren, A.F.M. van Hees, H.H. Bartelink, G.J. Nabuurs \& P.A. Slim, 1997. Bosontwikkeling in aanwezigheid van hoefdieren: een modelbenadering. In: Wieren, S.E., van, Groot Bruinderink, G.W.T.A., Jorritsma, I.T.M. en Kuiters, A.T. (eds) Hoefdieren in het boslandschap. Backhuys Publishers, Leiden, pp. 147-164.

Keuling, O., N. Stier \& M. Roth, 2008. How does hunting influence activity and spatial usage in wild boar Sus scrofa? European Journal of Wildlife Research 54: 729-737.

Kirby, K.J., 2001. The impact of deer on the ground flora of British broadleaved woodland. Forestry 74: 219-229.

Koelewijn, H.P., M. Pérez-Haro, H.A.H. Jansman, M.C. Boerwinkel, J. Bovenschen, D.R. Lammertsma, F.J.J. Niewold \& A.T. Kuiters, 2010. The reintroduction of the eurasian otter (Lutra lutra) into the Netherlands: hidden life revealed by noninvasive genetic monitoring. Conservation Genetics 11 : 601-614.

Koh, S., D.R. Bazely, A.J. Tanentzap, D.R. Voig \& E. Da Silva, 2010 Trillium grandiflorum height is an indicator of white-tailed deer density at local and regional scales. Forest Ecology and Management 259: 1472-1479.

Kowalczyk J, Z. Gębczyńska \& M. Krasińska, 1976. Bisoniana LXII. The digestibility of nutrients of natural diet by European bison in different seasons. Acta Theriologica 21:141-146. 
Krasinska, M., K. Cabon-Raczynska \& Z.A. Krasinski, 1987. Strategy of habitat utilization by European bison in the Bialowieza forest. Acta Theriologica 32: 147-202.

Krasinska, M. \& Krasinski, Z.A., 1995. Composition, group size, and spatial distribution of European bison bulls in Bialowieza Forest. Acta Theriologica 40: 1-21.

Krasinski Z.A. \& Krasinska M., 1992. Free ranging bison in Borecka Forest. Acta Theriologica 37: 301-317.

Kuipers, C.P., 2017. Mediating effect of the vegetation on deer forage behaviour in National Park 'De Hoge Veluwe'. MSc thesis, Wageningen University, Wageningen.

Kuiters, A.T., J.A. Koppe \& P.A. Slim, 2000. Begrazing in bosreservaten door (wilde) hoefdieren: een onderbelicht aspect? Nederlands Bosbouwtijdschrift 72: 108-112.

Kuiters, A.T. \& P.A. Slim, 2002. Regeneration of mixed deciduous forest in a Dutch forest-heathland, following a reduction of ungulate densities. Biological Conservation 105: 65-74.

Kuiters, A.T., G.W.T.A. Groot Bruinderink \& D.R. Lammertsma, 2005. Facilitative and competitive interactions between sympatric cattle, red deer and wild boar in Dutch woodland pastures. Acta Theriologica 50: 241-252.

Kuiters, A.T., P.A. Slim \& A.F.M. van Hees, 1997. Spontane bosverjonging en hoefdieren. In: S.E. van Wieren, G.W.T.A. Groot Bruinderink, I.T.M. Jorritsma \& A.T. Kuiters (red.), Hoefdieren in het boslandschap, pp. 99-129. Backhuys Publishers, Leiden.

Kuiters, A.T., L.A.M. Van der Sluijs \& G.A. Wytema, 2006. Selective bark-stripping of beech, Fagus sylvatica, by free-ranging horses. Forest Ecology and Management 222: 1-8.

Kuiters, A.T. \& D. de Vries, 2016. Damherten in de Manteling van Walcheren en de Kop van Schouwen. Beheer van damhertpopulaties in relatie tot beheerdoelstellingen en welzijnsaspecten. Alterra rapport 2723, Alterra, Wageningen.

Kuper, J., 2018. Natuurlijk bosbeheer. Bos-en wildbeheer moeten elkaar gaan dienen. Hoe de grote verloofing tot stand komt. Het Edelhert, herfst 2018: 12-15.

Lelieveld, G., P.M. van Bodegom \& W. Wamelink, 2019. No place to hide for lynx in the Netherlands. Limited forest cover hampers the availability. Lutra 62: 13-28.

LNV (Ministerie voor Landbouw, Natuur en Visserij), 2008. Natura 2000 profielendocument. Versie 1 september 2008. Ministerie van LNV, Directie Kennis, Ede.

Louwe Kooijmans, L., 2017. Onze vroegste voorouders. De geschiedenis van Nederland in de steentijd, van het begin tot 3000 vC. Bert Bakker, Amsterdam.

Maes, S.L., H. Blondeel, M.P. Perring, L. Depauw, G. Brūmelis, J Brunet, G. Decocq, J. den Ouden, W. Härdtle, R. Hédl, T. Heinken, S. Heinrichs, B. Jaroszewicz, K. Kirby, M. Kopecký, F. Máliš, M. Wulf \& K. Verheyen, 2019. Litter quality, land-use history, and nitrogen deposition effects on topsoil conditions across European temperate deciduous forests. Forest Ecology and Management 433: $405-418$.

Maisels, F.G., 1988. The feeding ecology of the Cyprus mouflon Ovis orientalis Gmelin 1774, in the Paphos forest, Cyprus. PhD Thesis University of Edinburgh.

Malhi, Y., C.E. Doughty, M. Galetti, F.A. Smith, J.C. Svenning \& J. Terborgh, 2016. Megafauna and ecosystem function from the Pleistocene to the Anthropocene. Proceedings of the National Academy of Sciences 113: 838-846.

Marchand, P., C. Redjadj, M. Garel, J.M. Cugnasse, D. Maillard \& A. Loison, 2013. Are mouflon Ovis gmelini musimon really grazers? A review of variation in diet composition. Mammal Review 43: 275-291.

Martin, J.-L., S.A. Stockton, S. Allombert \& A.J. Gaston, 2010. Top-down and bottom-up consequences of unchecked ungulate browsing on plant and animal diversity in temperate forests: lessons from a deer introduction. Biological Invasions 12: 353-371.

Martin, T.G., P. Arcese \& N. Scheerder, 2011. Browsing down our natural heritage: Deer impacts on vegetation structure and songbird populations across an island archipelago. Biological Conservation 144: 459-469.

Marozas, V., J. Baranauskaite \& K. Petelis, 2011. The Fallow deer influence on enclosure forest vegetation. Proceedings Rural Development 24-25 November 2011. Akademija, Lithuania.

Maublanc, M.-L., E. Bideau, C. Launay, B. Monthuir \& J.-F. Gerard, 2016. Indicators of ecological change (IEC) as efficient tools for managing roe deer populations: a case study. European Journal of Wildlife Research 62:189-197.

Maug, C., 2019. The impact of wild ungulates on tree species regeneration under varying light regimes in the Veluwe. MSc thesis, Wageningen University, Wageningen. 
McArthur, C., N.R. Marsh, D.C. Close, A. Walsh, S. Paterson, H. Fitzgerald \& N.W. Davies, 2003. Nursery conditions affect seedling chemistry, morphology and herbivore preferences for Eucalyptus nitens. Forest Ecology and Management 176: 585-594.

Mech, L.D., 1970. The wolf: the ecology and behavior of an endangered species. The Natural History Press, New York.

Mech, L.D. \& R.O. Peterson, 2003. Wolf-Prey Relations. In: Mech L.M. \& L. Boitani eds. (2003) Wolves: Behavior, ecology and conservation, pp 131-160. University of Chicago Press, Chicago.

Messier, F. 1991. The significance of limiting and regulating factors on the demography of moose and white-tailed deer. J. Anim. Ecol. 60: 377-393.

Mitchell, F.J.G. \& K.J. Kirby, 1990. The impact of large herbivores on the conservation of semi-natural woods in the British uplands. Forestry 63: 333-353.

Mohr, D., L.W. Cohnstaedt \& W. Topp, 2005. Wild boar and red deer affect soil nutrients and soil biota in steep oak stands of the Eifel. Soil Biology and Biochemistry 37: 693-700.

Moore, N.P., J.D. Hart, P.F. Kelly \& S.D. Langton, 2000. Browsing by fallow deer (Dama dama) in young broadleaved plantations: seasonality, and the effects of previous browsing and bud eruption. Forestry 73: 437-445.

Morellet, N., S. Champely, J.-M. Gaillard, P. Ballon \& Y. Boscardin, 2001. The browsing index: new tool uses browsing pressure to monitor deer populations. Wildlife Society Bulletin 29:1243-1252.

Morellet N., J.-M. Gaillard, A.J.M. Hewison, P. Ballon, Y. Boscardin Y, P. Duncan, F. Klein \& D. Maillard, 2007. Indicators of ecological change: new tools for managing populations of large herbivores. Journal of Applied Ecology 44:634-643.

Mulder, J., 1992. De lynx nog niet los. Nederlandse natuur te klein voor lynxen. Rapport Natuurmonumenten, 's Graveland.

Neefjes, J., 2018. Landschapsbiografie van de Veluwe. Rijksdienst voor het Cultureel Erfgoed, Amersfoort.

Nessing, G. \& S. Zerbe, 2002. Wild und Waldvegetation - Ergebnisse des Monitorings im Biosphärenreservat Schorfheide-Chorin (Brandenburg) nach 6 Jahren. Allgemeine Forst- und Jagdzeitschrift 173: 177-185.

Nyssen, B., J. den Ouden \& K. Verheyen, 2013. Amerikaanse vogelkers. Van bospest tot bosboom. KNNV, Zeist.

Obidzińskia, A., R. Miltko, L. Bolibok, M. Wajdzik, J. Skubis \& P. Nasiadka, 2017. Variation of natural diet of free ranging mouflon affects their ruminal protozoa composition. Small Ruminant Research 157: $57-64$.

Odermatt, O., 2014. Wann sind die kritischen Phasen? Wald und Holz 2/14: 23-26.

Oheimb, G. von, M. Schmidt, W.-U. Kriebitzsch \& H. Ellenberg, 2005. Dispersal of vascular plants by game in northern Germany. Part II: Red deer (Cervus elaphus). European Journal of Forest Research 124: 55-65.

Os, V. van, 2018. Analysis of ungulate population dynamics at De Hoge Veluwe National Park: Testing field count accuracy. MSc thesis, Wageningen University.

Ouden, J. den \& Th. Spek (ed.), 2007. Ontstaanswijze van eikenclusters in het natuurterrein De Wilde Kamp bij Garderen: Landschapsgeschiedenis, bodemontwikkeling en vegetatiegeschiedenis. Rapportage Archeologische Monumentenzorg 131B, RACM, Amersfoort. Provincie Gelderland, 2017. Beheerplan Natura 2000 Veluwe (057). Provincie Gelderland, Arnhem.

Ouden, J. den, P. Copini \& U. Sass-Klaassen, 2009. Een nieuwe kijk op oude eiken. De Levende Natuur 110: 83-87.

Ouden, J. den, H. Schoonderwoerd \& J.P.G. de Klein, 2016. Graasdruk-monitoring op de Veluwe. Een voorstel. Silve rapport 16-20, Silve, Wageningen.

Ouden, J. den, M.J. Schelhaas, R. van Duuren, S. Clerkx, R. de Waal \& B. Lerink, 2020. Kan uitstel van houtoogst bijdragen aan $\mathrm{CO}_{2}$-mitigatie? WENR Rapport 2994, WENR, Wageningen.

Pellerin, M., S. Siad, E. Richard, J.L. Hamann, C. Dubois-Coli \& P. Hum, 2010. Impact of deer on temperate forest vegetation and woody debris as protection of forest regeneration against browsing. Forest Ecology and Management 260: 429-437.

Pierik, H.J., R.J. van Lanen, M.T.I.J. Gouw-Bouman, B.J. Groenewoudt, J. Wallinga \& W.Z. Hoek, 2018. Controls on late-Holocene drift-sand dynamics: The dominant role of human pressure in the Netherlands. The Holocene 28: 1361-1381.

Putman, R.J., 1996. Competition and resource partitioning in temperate ungulate assemblages. Chapman \& Hall, London. 
Putman, R.J. \& B.W. Staines, 2004. Supplementary winter feeding of wild red deer Cervus elaphus in Europe and North America: justifications, feeding practice and effectiveness. Mammal Review 34: 285-306.

Ramirez, J.I., P.A. Jansen \& L. Poorter, 2018. Effects of wild ungulates on the regeneration, structure and functioning of temperate forests: A semi-quantitative review. Forest Ecology and Management 424: 406-419.

Ramirez J.I., 2019. Wild ungulates as forest engineers. Dissertatie, Wageningen University, Wageningen.

Ramirez, J.I., P.A. Jansen, J. den Ouden, L. Goudzwaard \& L. Poorter, 2019. Long-term effects of wild ungulates on the structure, composition and succession of temperate forests. Forest Ecology and Management 432: 478-488.

Randi, E. \& M. Apollonio, 1988. Low biochemical variability in European fallow deer (Dama dama L.): natural bottlenecks and the effects of domestication. Heredity 61: 405-410.

Reed, J.M., P.D. Doerr \& J.R. Walters, 1986. Determining minimum population sizes for birds and mammals. Wildlife Society Bulletin 14: 255-261.

Reijnders, P.J.H. \& H.E. van der Veen, 1974. Over de oorzaken en effecten van 'schillen' door edelherten en over de relatie tussen roodwildbeheer en bosbeheer in de Nederlandsche situatie. Nederlands Bosbouwtijdschrift 46: 113-138.

Reimoser, F., 2003. Steering the impacts of ungulates on temperate forests. Journal of Nature Conservation 10: 243-252.

Renaud, P.C., H. Verheyden-Tixier \& B. Dumont, 2003. Damage to saplings by red deer (Cervus elaphus): effect of foliage height and structure. Forest Ecology and Management 181: 31-37.

Rheinberger, C. \& W. Suter, 2006. Schälungen durch den Rothirsch: eine Fallstudie in den Nordostschweizer Voralpen. Schweizerische Zeitschrift für Forstwesen 157: 157-156.

Risch, A.C., S. Wirthner, M.D. Busse, D.S. Page-Dumroese \& M. Schütz, 2010. Grubbing by wild boars (Sus scrofa L.) and its impact on hardwood forest soil carbon dioxide emissions in Switzerland. Oecologia, 164: 773-784.

Rowcliffe, J.M., J. Field, S.T. Turvey \& C. Carbone, 2008. Estimating Animal Density Using Camera Traps Without the Need for Individual Recognition. Journal of Applied Ecology 45: 1228-1236.

Rowcliffe, J. M., C. Carbone, R. Kays, B. Kranstauber \& P.A. Jansen, 2014. Density estimation using camera trap surveys: the random encounter model. Camera trapping: wildlife management and research. CSIRO Publishing, Melbourne, Australia, pp. 317-324.

Royo, A.A., D.W. Kramer, K.V. Miller, N.P. Nibbelink \& S.L. Stout, 2016. The canary in the coal mine: Sprouts as a rapid indicator of browse impact in managed forests. Ecological Indicators 69: 269-275.

Royo, A.A., D.W. Kramer, K.V. Miller, N.P. Nibbelink \& S.L. Stout, 2017. Spatio-temporal variation in foodscapes modifies deer browsing impact on vegetation. Landscape Ecology 32:2281-2295

Russo L., G. Massei \& P. Genov, 1997. Daily home range and activity of wild boar in a Mediterranean area free from hunting. Ethology Ecology \& Evolution 9:287-294.

Sabo, E. K.L. Frerker, D.M. Waller \& E. L. Kruger, 2017. Deer-mediated changes in environment compound the direct impacts of herbivory on understorey plant communities. Journal of Ecology 105: $1386-1398$.

Schaetzen, F. de, F. van Langevelde \& M.F. WallisDeVries, 2018. The influence of wild boar (Sus scrofa) on microhabitat quality for the endangered butterfly Pyrgus malvae in the Netherlands. Journal of Insect Conservation 22: 51-59.

Schäfer, D., D. Prati, P. Schall, C. Ammer \& M. Fischer, 2019. Exclusion of large herbivores affects understorey shrub vegetation more than herb vegetation across 147 forest sites in three German regions. PLOS ONE 14(7).

Schmidt, M., K. Sommer, W.-U. Kriebitzsch, H. Ellenberg \& G. von Oheimb, 2004. Dispersal of vascular plants by game in northern Germany. Part I: Roe deer (Capreolus capreolus) and wild boar (Sus scrofa). European Journal of Forest Research 123: 167-176.

Schütz, M., 2005. Huftiere als 'Driving Forces' der Vegetationsentwicklung. Forum für Wissen 2005: 27-30.

Siepel, H., 1992. Bosgebonden fauna; een faunistische aanvulling op bosgemeenschappen. RINrapport 92/33, Instituut voor Bos- en Natuuronderzoek, Arnhem. 
Sitters, J. \& W.S. Andriuzzi, 2019. Impacts of browsing and grazing ungulates on soil biota and nutrient dynamics. In: I.J. Gordon \& H.H.T. Prins (eds). The ecology of browsing and grazing II. Ecological Studies 239. Springer Nature Switzerland.

Smit, R., J. Bokdam \& M.F. Wallis de Vries, 1998. Grote herbivoren \& vegetatie in het Nationale Park De Hoge veluwe. Effecten van rasterverwijdering. Landbouwuniversiteit Wageningen, Wageningen.

Smit, R., J. Bokdam, J. den Ouden, H. Olff, H. Schot-Opschoor \& M. Schrijvers, 2001. Effects of introduction and exclusion of large herbivores on small rodent communities. Plant Ecology 155: 119-127.

Smit, R., 2002. The secret life of woody species. Dissertatie Wageningen Universiteit, Wageningen.

Smit, C., 2005. Facilitation of tree regeneration in wood pastures. Dissertatie University of Fribourg, Fribourg, Zwitserland.

Smit, C., C. Vandenberghe, J. den Ouden \& H. Müller-Schärer, 2007. Nurse plants, tree saplings and grazing pressure: Changing facilitation along a biotic environmental gradient. Oecologia 152: 265-273.

Smith, D.W., R.O. Peterson, D.R. MacNultry \& M. Kohl, 2016. The big scientific debate: trophic cascades. Yellowstone Science 24: 70-71.

Smulders, M.J.M., P.F.P. Arens, H.A.H. Jansman, J. Buiteveld, G.W.T.A. Groot Bruinderink \& H.P. Koelewijn, 2006. Herintroduceren van soorten, bijplaatsen of verplaatsen: een afwegingskader. Alterra-rapport 1390, Alterra, Wageningen.

Sodeikat, G. \& K. Pohlmeyer, 2003. Escape movements of family groups of wild boar Sus scrofa influenced by drive hunts in Lower Saxony, Germany. Wildlife Biology 9: 257-263.

Staatsbosbeheer, 2015. Groeiende toekomst. De bosvisie van Staatsbosbeheer. Staatsbosbeheer, Driebergen.

Stankowich, T. 2008. Ungulate flight responses to human disturbance: A review and meta-analysis. Biological Conservation 141: 2159-2173.

Stillfried, M., P. Gras, K. Börner, F. Göritz, J. Painer, K. Roellig, M. Wenzler, H. Hofer, S. Ortmann \& S. Kramer-Schadt, 2017. Secrets of Success in a Landscape of Fear: Urban Wild Boar Adjust Risk Perception and Tolerate Disturbance. Frontiers in Ecology and Evolution. 5: 157.

Stokely, T.D. \& M.G. Betts, 2020. Deer-mediated ecosystem service versus disservice depends on forest management intensity Journal of Applied Ecology 57:31-42.

Stumpel, A.H.P., 2004. Reptiles and amphibians as targets for nature management. Alterra Scientific Contributions 13. Alterra, Wageningen.

Sütő, D., J. Farkas, S. Siffer, G. Schally \& K. Katona, 2019. Spatio-temporal pattern of wild boar rooting in a Central European dry oak forest. European Journal of Forest Research (2019).

Sykes, N. \& R. Putman, 2014. Management of ungulates in the $21^{\text {st }}$ century: how far have we come? In: Behaviour and management of European ungulates. Edited by R. Putman \& M. Apollonio. Cambridge University Press, Cambridge, pp. 267-289.

Tanentzap, A.J., K.J. Kirby \& E. Goldberg, 2012. Slow responses of ecosystems to reductions in deer (Cervidae) populations and strategies for achieving recovery. Forest Ecology and Management 264: 159-166.

Valdés-Correcher, E., E. Rodriguez, Y.J.M. Kemp, M.J. Wassen \& J.P.G.M. Cromsigt, 2018. Comparing the impact of a grazing regime with European bison versus one with free-ranging cattle on coastal dune vegetation in the Netherlands. Mammal Research 63:455-466.

Valdés, A, J. Lenoir, P. De Frenne et al., 2019. High ecosystem service delivery potential of small woodlands in agricultural landscapes. Journal of Applied Ecology 2019; 00:1-13.

Veen, P., B. Maes \& E. van den Dool, 2017. Het Elspeterbos. Verleden, heden en toekomst van een historisch malenbos. Veen Ecology/Ecologisch Adviesbureau Maes, Nunspeet/Utrecht.

Vera, F.W.M., 2000. Grazing ecology and forest history. CAB international, Oxon.

Verbeek, I., 2016. Forest regeneration and browsing by ungulates. MSc thesis, Wageningen University, Wageningen.

Vereniging Natuurmonumenten, 2006. Bosbeleid van Natuurmonumenten. Vereniging Natuurmonumenten, 's Graveland.

Vereniging Natuurmonumenten, 2014. Toekomstvisie Veluwezoom (Nationaal Park Veluwezoom en IJsseluiterwaarden). Vereniging Natuurmonumenten, 's Graveland.

Vereniging Wildbeheer Veluwe, 2019. Jaarrapportage grofwild 2018-2019 1 april 2018 t/m 31 maart 2019. Nieuwsbrief nr. 45, Vereniging Wildbeheer Veluwe, Vaassen. 
Vink, V., 2020. Woodland regeneration in relation to grazing and fencing in the Hoge Veluwe National Park, the Netherlands. MSc thesis, Universiteit van Amsterdam, Amsterdam.

Vospernik, S. 2006. Probability of bark stripping damage by red deer (Cervus elaphus) in Austria. Silva Fennica 40: 589-601.

Vries, W. de, M.J. Weijters, J.J. de Jong, S.P.J. van Delft, J. Bloem, A. van den Burg, G.A. van Duinen, E. Verbaarschot \& R. Bobbink, 2019. Verzuring van loofbossen op droge zandgronden en herstelmogelijkheden door steenmeeltoediening. Rapport OBN229-DZ. Vereniging van Bos- en Natuurterreineigenaren (VBNE), Driebergen.

Waternet, 2019. Damhertendossier. Ontwikkeling damhert- en reeënpopulatie AWD 2019 https://awd.waternet.nl/beheer/projecten/dossier-damherten/documentatie/ (8 maart 2020)

Wieren, S.E. van \& A.T. Kuiters, 1997. Hoefdieren in het bos-heide landschap van de hogere zandgronden: evaluatie en perspectief. In: Wieren, S.E., van, Groot Bruinderink, G.W.T.A., Jorritsma, I.T.M. and Kuiters, A.T. (eds) Hoefdieren in het boslandschap. Backhuys Publishers, Leiden, pp. 131-145.

Wieren, S.E. van, G.W.T.A. Groot Bruinderink, I.T.M. Jorritsma \& A.T. Kuiters, A.T. (eds), 1997. Hoefdieren in het boslandschap. Backhuys Publishers, Leiden.

Wieren, S.E. van, H.H.T. Prins, Groot Bruinderink, G.W.T.A., D.R. Lammertsma, K. Kramer, S. Wijdeven, A.T. Kuiters, P. Cornelissen, J.Th. Vulink, F. de Roder \& V. Wigbels, 1999. Aantalsontwikkeling bij hoefdieren. In: Groot Bruinderink, G.W.T.A., D.R. Lammertsma, K. Kramer, S. Wijdeven, J.M. Baveco, A.T. Kuiters, P. Cornelissen, J.Th. Vulink, H.H.T. Prins, S.E. van Wieren, F. de Roder \& V. Wigbels. Dynamische interacties tussen hoefdieren en vegetatie in de Oostvaardersplassen. IBN-rapport 436. Instituut voor Bos- en Natuuronderzoek, Wageningen.

Wirthner, S., M. Schütz, D.S. Page-Dumroese, M.D. Busse, J.W. Kirchner \& A.C. Risch, 2012. Do changes in soil properties after rooting by wild boars (Sus scrofa) affect understory vegetation in Swiss hardwood forests? Canadian Journal of Forest Research 42: 585-592.

Wisent op de Veluwe, 2017. Jaarverslag 2017. (WisentopdeVeluwe.nl, geraadpleegd 21 mei 2020).

Woersem, A. van \& V. Elders, 2016. Eindrapportage gps-halsbandenonderzoek naar terreingebruik van edelherten op Veluwezoom. Apex Ecologie, Wageningen.

Wolfe, M. L. \& E C. von Berg, 1988. Deer and forestry in Germany. Half a century after Aldo Leopold. Journal of Forestry 86: 25-31.

Wonders, K., 2014. Variation in browsing. In a constant herbivore population. MSc thesis, Wageningen University, Wageningen.

Worm, P.B. \& S.E. Van Wieren, 1996. Reactie van edelherten op veranderend beheer van Vereniging Natuurmonumenten. De Levende Natuur 97: 27-32.

Wubben, W., 2005. The relation between deer density and browsing on trees. MSc thesis Wageningen University, Wageningen.

Young, T.P., 1994. Natural die-offs of large mammals: Implications for conservation. Conservation Biology 8: 410-418.

Zachos, F.E., G.M. Hajji, S.S. Hmwe, G.B. Hartle, R. Lorenzini \& S. Mattioli, 2009. Population viability analysis and genetic diversity of the endangered red deer Cervus elaphus population from Mesola, Italy. Wildlife Biology 15: 175-186. 


\section{Bijlage 1 Insteek boshabitattypen Veluwe}

In de opdracht van de Provincie Gelderland voor het vervaardigen van dit rapport is een nadere uitwerking gemaakt van de kwaliteitskenmerken van de habitattypen Oude eikenbossen en Beukeneikenbossen met hulst. Hieronder is de integrale tekst opgenomen van deze 'Insteek boshabitattypen op de Veluwe'.

Op de Veluwe worden, afgezien van het Jeneverbesstruweel, vier boshabitattypen onderscheiden.

$\begin{array}{ll}\text { H9120 } & \text { Beuken-eikenbossen met Hulst } \\ \text { H9190 } & \text { Oude eikenbossen } \\ \text { H91EoC } & \text { Beekbegeleidende bossen } \\ \text { H91Do } & \text { Hoogveenbossen }\end{array}$

Het onderscheid tussen de genoemde typen is beschreven in de zogenaamde profieldocumenten op basis van een plantensociologische indeling. Ook in het Natura 2000-beheerplan worden de typen (op basis van de profieldocumenten) nader beschreven.

Ondanks deze beschrijvingen is er met name over de eerste twee bostypen herhaaldelijk discussie. Om voort te kunnen met behoud en herstelplannen in het kader van Natura 2000, is een duidelijk onderscheid gewenst. In het navolgende wordt beknopt beschreven wat de onderscheidende uitgangspunten zijn voor de eerste twee bostypen. De laatste twee typen blijven hier buiten beschouwing.

Het onderscheiden van verschillende typen in de natuur is per definitie kunstmatig. Het gaat voorbij aan alle overgangsvormen, natuurlijke ontwikkelingen en antropogene invloeden. Dat geldt dus ook voor het onderstaande onderscheid.

\section{H9120 Beuken-eikenbossen met hulst}

Bodem: $\quad$ Oude bosbodem (> 1850), holtpodzol, lemig zand

Botanische aanduiding: Fago-Quercetum

Karakteristiek boomlaag: Beuk dominant, zomereik (soms wintereik) in menging. Doorgaans weinig lichtdoorlatende gesloten kroonlaag. Open plekken worden vrij snel weer opgevuld.

Struiklaag: Hulst, Taxus, verjonging Beuk, Eik, Lijsterbes, Vuilboom in

Kruidlaag:

Successie: verjongingsgaten.

Vaak pleksgewijs: Dalkruid, Witte klaverzuring, Valse salie Ontwikkeling naar $100 \%$ Beuk (Deschampsio Fagetum). Vervalfase is rijk aan paddenstoelen en mossen en geeft ruimte aan verjonging van diverse boom en struiksoorten. Dit is het stadium van dit habitattype met de hoogste biodiversiteit. Naar verwachting neemt de Beuk het hier uiteindelijk weer over.

Zorgen: De standplaats is ook bijzonder geschikt voor Douglas en Larix. Soorten die vaak in de directe omgeving aanwezig zijn. In verjongingsgaten kan dominantie optreden van deze soorten. Dat is ongewenst.

Klimaatverandering kan leiden tot afname van de vitaliteit van de Beuk. Afgezien van het feit dat hier weinig aan te doen is, kan het zelfs voordelig zijn voor het behoud van de eik in de opstand.

Beheer: Het beheer kan in principe beperkt blijven tot het op afstand houden van dominante exoten (douglas, lariks, Amerikaanse eik, tamme kastanje). Houtoogst wordt niet uitgesloten, maar zou beperkt moeten blijven tot Beuk en genoemde exoten. Het is gewenst de aanwezige eiken als 'habitatbomen' te sparen. Hiervoor kan het noodzakelijk zijn om dit soort bomen periodiek vrij te stellen. 
Wildbeheer:

Bij oogstwerkzaamheden heeft, in verband met ongewenste bodemverdichting bij inzet van zware machines, de inzet van paard of lier bij uitslepen de voorkeur.

De wildstand (herten, varkens) dient op een zodanig niveau te worden gehandhaafd dat verjonging van loofhoutsoorten en bloeiende kruiden ruim voorhanden blijven. In de praktijk betekent dit een aanzienlijk lagere wildstand dan nu op de Veluwe het geval is.

H9190 Oude eikenbossen

Bodem: $\quad$ Oude bosbodem (> 1850), humuspodzol, leemarm zand

Botanische aanduiding: Betulo-Quercetum roboris

Karakteristiek boomlaag: Zomereik en/of Ruwe Berk dominant. Veel licht doorlatende meer of minder gesloten boomlaag. Open plekken kunnen langere tijd open blijven. Het bosbouwuitgangspunt van $60 \%$ kroonbedekking is voor dit habitattype niet aan de orde. Ook een mozaïek van bos met grote open plekken met heide wordt als geheel tot dit habitattype gerekend. De belangrijkste voorwaarden zijn de oude bosbodem en de aanwezigheid van dynamiek door verjonging in de open plekken.

Struiklaag: $\quad$ Verspreid Lijsterbes en Vuilboom. Kamperfoelie komt voor, maar blijft aan de grond.

Kruidlaag: Vaak dominantie van bosbes (soms rode bosbes), Bochtige smele of Pijpenstrootje. Incidenteel dominantie van Adelaarsvaren. Vaak ook soorten die een rijkere ontwikkeling indiceren, zoals Havikskruiden, Hengel en Valse salie. Op open plekken kan struikheide langdurig aanwezig zijn.

Successie: Op iets rijkere bodem is een ontwikkeling richting beuken-eikenbos te verwachten. Zolang Eik en/of Berk dominant zijn, wordt de vegetatie tot het oude eikenbos-type gerekend. Zodra Beuk dominant wordt, zal de aanduiding voor het habitattype worden aangepast.

Zorgen: Door stikstofdepositie gaat de vitaliteit van de eik in dit habitattype hard achteruit. Dat levert grote open plekken op waar mede door de hoge wilddruk verjonging van loofhout uitblijft. Op dit soort plekken kan verjonging van grove den, douglas of lariks de overhand krijgen. Langdurige open plekken zijn op zich geen groot probleem. De overname door naaldhout zou echter het einde van het habitattype betekenen. Dat is niet gewenst.

Beheer: Het beheer dient beperkt blijven tot het op afstand houden van dominante exoten (douglas, lariks, Amerikaanse vogelkers).

Houtoogst is, zeker gezien de matige vitaliteit van dit habitattype, voorlopig niet gewenst. Inzet van zware machines wordt uitgesloten.

Een eventuele successie naar Beuken-eikenbos moet niet door beheer worden gehinderd. Blijkbaar is dan de tijd/bodem rijp voor een dergelijke ontwikkeling.

Met de inzet van een hakhoutbeheer zou de successie kunnen worden tegengehouden. Mede gezien het grote risico op de Veluwe voor het niet meer uitlopen van de stobben, is hakhoutbeer ongewenst.

De (winter)eikenstrubben vallen ook onder dit habitattype. Een bijzonder beheeraspect hierbij is dat recreanten op afstand moeten worden gehouden. Het lopen of fietsen (ATB) tussen de strubben is zeer ongewenst.

Wildbeheer: De wildstand (herten, varkens) dient op een zodanig niveau te worden gehandhaafd dat verjonging van loofhoutsoorten en bloeiende kruiden voldoende voorhanden blijven. Zeker bij de huidige slechte vitaliteit is het voorhanden zijn van voldoende verjonging cruciaal. In de praktijk betekent dit een aanzienlijk lagere wildstand dan nu op de Veluwe het geval is. 
Wageningen University /

Wageningen Environmental Research Postbus 47

6700 AA Wageningen

T 0317480700

www.wur.nl/environmental-research

Wageningen University /

Wageningen Environmental Research

Rapport 3013

ISSN 1566-7197
De missie van Wageningen University \& Research is 'To explore the potential of nature to improve the quality of life'. Binnen Wageningen University \& Research bundelen Wageningen University en gespecialiseerde onderzoeksinstituten van Stichting Wageningen Research hun krachten om bij te dragen aan de oplossing van belangrijke vragen in het domein van gezonde voeding en leefomgeving. Met ongeveer 30 vestigingen, 5.000 medewerkers en 12.000 studenten behoort Wageningen University \& Research wereldwijd tot de aansprekende kennisinstellingen binnen haar domein. De integrale benadering van de vraagstukken en de samenwerking tussen verschillende disciplines vormen het hart van de unieke Wageningen aanpak.

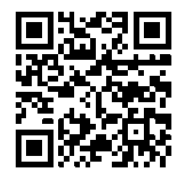





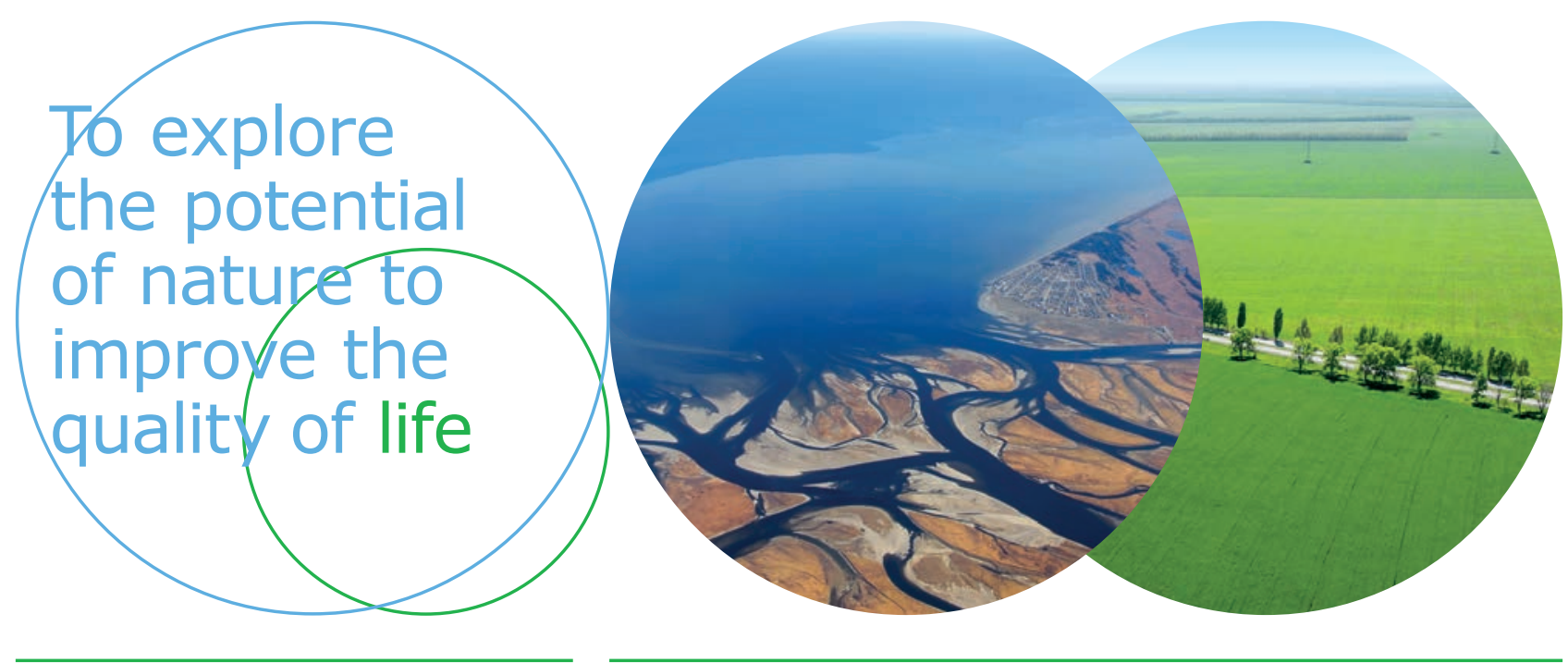

Wageningen University /

Wageningen Environmental Research Postbus 47

$6700 \mathrm{AB}$ Wageningen

T 317480700

www.wur.nl/environmental-research

Rapport 3013

ISSN 1566-7197
De missie van Wageningen University \& Research is 'To explore the potential of nature to improve the quality of life'. Binnen Wageningen University \& Research bundelen Wageningen University en gespecialiseerde onderzoeksinstituten van Stichting Wageningen Research hun krachten om bij te dragen aan de oplossing van belangrijke vragen in het domein van gezonde voeding en leefomgeving. Met ongeveer 30 vestigingen, 5.000 medewerkers en 12.000 studenten behoort Wageningen University \& Research wereldwijd tot de aansprekende kennisinstellingen binnen haar domein. De integrale benadering van de vraagstukken en de samenwerking tussen verschillende disciplines vormen het hart van de unieke Wageningen aanpak. 